Experimental and Spectral Supporting Material

For

\title{
“Quassinoid Support Studies: Fused Carbocycle Synthesis from Benzoic Acid Derivatives via 5-Hexynyl and 6-Heptynyl Radical Cyclizations"
}

\author{
Valerie Cwynar, Matthew G. Donahue, David J. Hart* and Dexi Yang \\ Department of Chemistry, The Ohio State University, Columbus, Ohio 43210, USA
}

\section{Contents}

1. Experimental procedures for all reactions described in text.

2. Selected ${ }^{1} \mathrm{H}$ and ${ }^{13} \mathrm{C}$ NMR spectra for all new compounds described in text.

This supporting information is presented in the order of compound number and spectra for compound immediately follow the experiment that describes their preparation. 


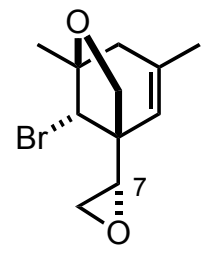

6

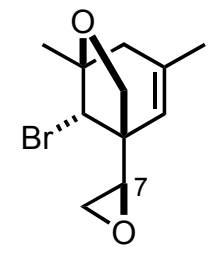

7-epi-6

Epoxides 6 and 7-epi-6. A solution of $17.8 \mathrm{~g}(141.3 \mathrm{mmol})$ dimethyl sulfate and $9.7 \mathrm{~g}$

(155.5 mmol) dimethyl sulfide in $150 \mathrm{~mL}$ acetonitrile was stirred at $\mathrm{rt}$ for $18 \mathrm{~h}$. Upon cooling on an ice $-\mathrm{H}_{2} \mathrm{O}$ bath, $8.4 \mathrm{~g}(155.5 \mathrm{mmol})$ of sodium methoxide was added and the solution was stirred for $15 \mathrm{~min}$ at $0{ }^{\circ} \mathrm{C}$, then $23.1 \mathrm{~g}(94.2 \mathrm{mmol})$ of aldehyde $5 \mathrm{in} 40 \mathrm{~mL}$ of acetonitrile was added. After stirring for $1 \mathrm{~h}$ at $0{ }^{\circ} \mathrm{C}$, the solution was poured into $100 \mathrm{~mL} \mathrm{H}_{2} \mathrm{O}$ and the aqueous phase was extracted with three $50-\mathrm{mL}$ portions of ether. The combined organic phases were dried $\left(\mathrm{MgSO}_{4}\right)$, filtered, and concentrated in vacuo to give a yellow oil. The yellow oil was chromatographed over $100 \mathrm{~g}$ of silica gel (hexanes-ethyl acetate, 10:1) to afford $18.4 \mathrm{~g} \mathrm{(75 \% )}$ of a 2:1 mixture of 6 and 7-epi-6, respectively, as a pale yellow oil. The epoxides were separated by chromatography of $2 \mathrm{~g}$ portions using MPLC (hexanes-ethyl acetate, 15:1): Less polar Epoxide 6: IR (thin film) $1666 \mathrm{~cm}^{-1} ;{ }^{1} \mathrm{H}$ NMR $\left(\mathrm{CDCl}_{3}, 400 \mathrm{MHz}\right) \delta 1.37\left(\mathrm{~s}, 3 \mathrm{H}, \mathrm{CH}_{3}\right)$, $1.70\left(\mathrm{~s}, 3 \mathrm{H},=\mathrm{CCH}_{3}\right), 2.06,2.42\left(\mathrm{ABq}, J=18.2 \mathrm{~Hz}, 2 \mathrm{H}, \mathrm{CH}_{2}\right), 2.59(\mathrm{dd}, J=4.4,2.8 \mathrm{~Hz}, 1 \mathrm{H}$, $\mathrm{C}_{2} \mathrm{CHOC}$ ), $2.82\left(\mathrm{t}, J=4.4 \mathrm{~Hz}, 1 \mathrm{H}, \mathrm{CH}_{2} \mathrm{C} \underline{\mathrm{HOC}}\right), 3.05\left(\mathrm{dd}, J=4.0,2.8 \mathrm{~Hz}, 1 \mathrm{H}, \mathrm{C}_{2} \mathrm{CHOC}\right)$, 3.79 and $3.87\left(\mathrm{ABq}, J=7.0 \mathrm{~Hz}, 2 \mathrm{H}, \mathrm{CH}_{2} \mathrm{O}\right), 4.00(\mathrm{~d}, J=0.8 \mathrm{~Hz}, 1 \mathrm{H}, \mathrm{CHBr}), 5.21(\mathrm{~m}, 1 \mathrm{H},=\mathrm{CH})$; ${ }^{13} \mathrm{C} \mathrm{NMR}\left(\mathrm{CDCl}_{3}, 100 \mathrm{MHz}\right) \delta 22.0(\mathrm{q}), 23.0(\mathrm{q}), 43.6(\mathrm{t}), 43.8(\mathrm{t}), 48.2(\mathrm{~s}), 51.9$ (d), $56.0(\mathrm{~d})$, $76.2(\mathrm{t}), 81.4$ (s), 119.8 (d), $135.9(\mathrm{~s})$; exact mass calcd. for $\mathrm{C}_{11} \mathrm{H}_{15} \mathrm{BrO}_{4}(\mathrm{M}+\mathrm{Na})^{+} \mathrm{m} / \mathrm{z} 281.0153$, found $\mathrm{m} / \mathrm{z}$ 281.0152. Anal. Calcd for $\mathrm{C}_{11} \mathrm{H}_{15} \mathrm{BrO}_{4}$ : $\mathrm{C}, 50.98 ; \mathrm{H}$, 5.83. Found: $\mathrm{C}, 51.20 ; \mathrm{H}, 5.91$.

7-Epi-6: ${ }^{1} \mathrm{H} \mathrm{NMR}\left(\mathrm{CDCl}_{3}, 500 \mathrm{MHz}\right) \delta 1.37\left(\mathrm{~s}, 3 \mathrm{H}, \mathrm{CH}_{3}\right), 1.74\left(\mathrm{~s}, 3 \mathrm{H},=\mathrm{CCH}_{3}\right), 2.18,2.36(\mathrm{ABq}$, 
$\left.J=18.0 \mathrm{~Hz}, 2 \mathrm{H}, \mathrm{CH}_{2}\right), 2.79\left(\mathrm{t}, J=4.2 \mathrm{~Hz}, 1 \mathrm{H}, \mathrm{CH}_{2} \underline{\mathrm{CHOC}}\right.$ ), $2.99(\mathrm{dd}, J=4.5,3.0 \mathrm{~Hz}, 1 \mathrm{H}$, $\left.\mathrm{C}_{2} \mathrm{CHOC}\right), 3.06\left(\mathrm{dd}, J=4.2,3.0 \mathrm{~Hz}, 1 \mathrm{H}, \underline{\mathrm{C}}_{2} \mathrm{CHOC}\right), 3.85$ and $3.87(\mathrm{ABq}, J=7.0 \mathrm{~Hz}, 2 \mathrm{H}$, $\left.\mathrm{CH}_{2} \mathrm{O}\right), 3.91(\mathrm{~d}, \mathrm{~J}=0.8 \mathrm{~Hz}, 1 \mathrm{H}, \mathrm{CHBr}), 5.42(\mathrm{~m}, 1 \mathrm{H},=\mathrm{CH}) ;{ }^{13} \mathrm{C} \mathrm{NMR}\left(\mathrm{CDCl}_{3}, 125 \mathrm{MHz}\right) \delta 21.9$ (q), $22.8(\mathrm{q}), 43.5(\mathrm{t}), 43.9(\mathrm{t}), 47.9(\mathrm{~s}), 52.6(\mathrm{~d}), 55.4(\mathrm{~d}), 76.4(\mathrm{t}), 81.9(\mathrm{~s}), 121.7(\mathrm{~d}), 135.8(\mathrm{~s})$ exact mass calcd. for $\mathrm{C}_{11} \mathrm{H}_{15} \mathrm{BrO}_{4}(\mathrm{M}+\mathrm{Na})^{+} \mathrm{m} / \mathrm{z} 281.0153$, found $\mathrm{m} / \mathrm{z}$ 281.0142. Anal. Calcd for $\mathrm{C}_{11} \mathrm{H}_{15} \mathrm{BrO}_{4}: \mathrm{C}, 50.98 ; \mathrm{H}, 5.83$. Found: C, 51.22; H, 5.98. 


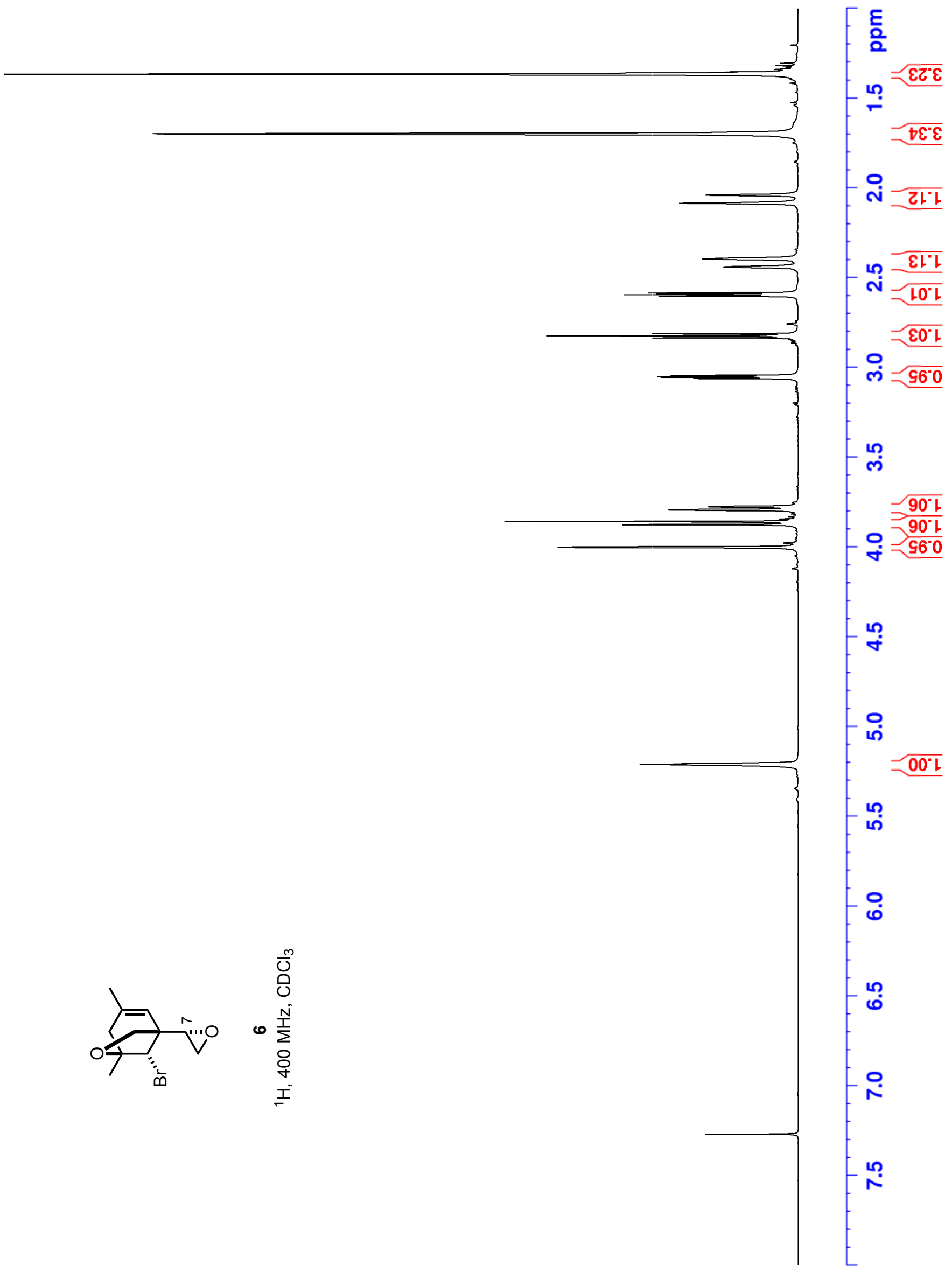




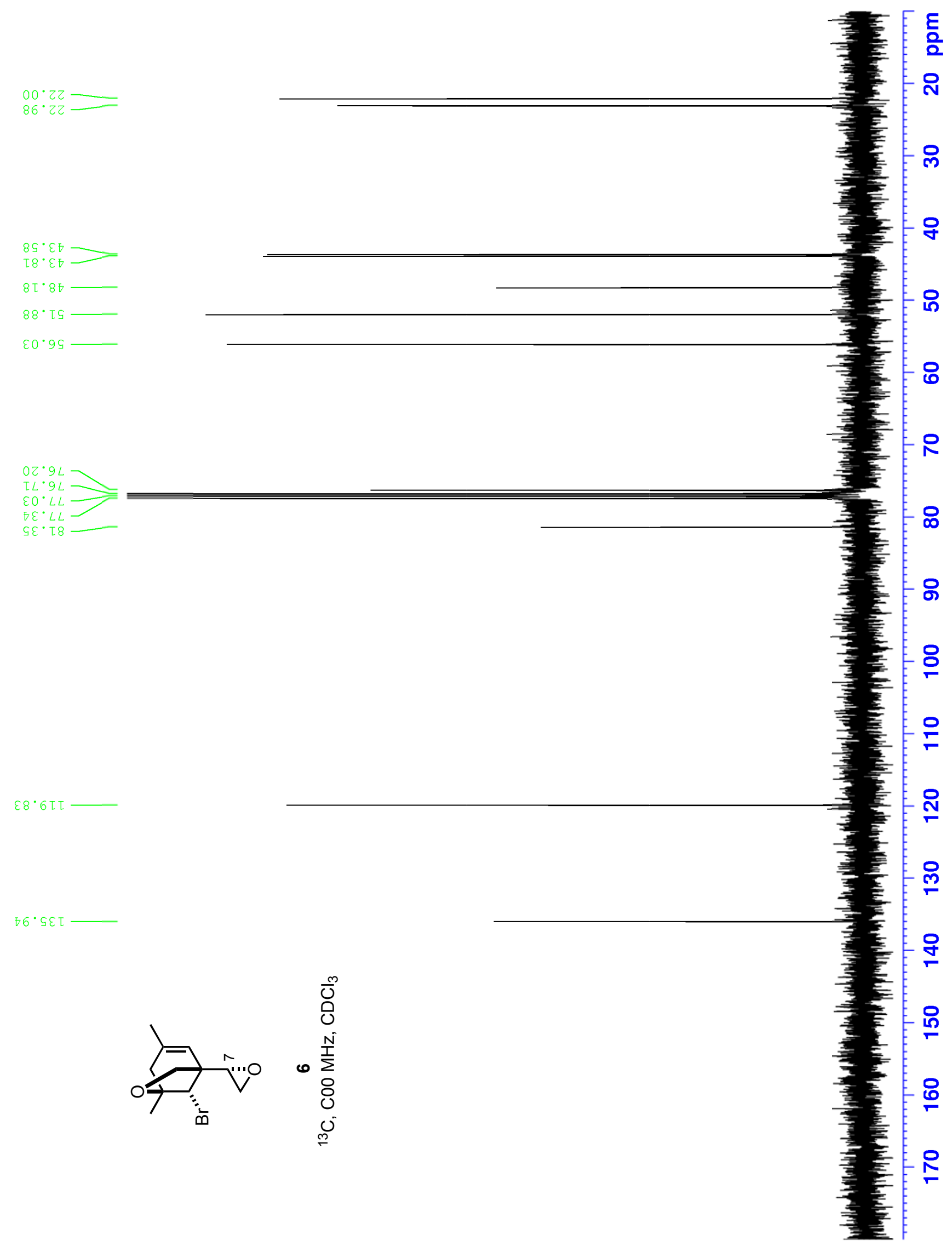




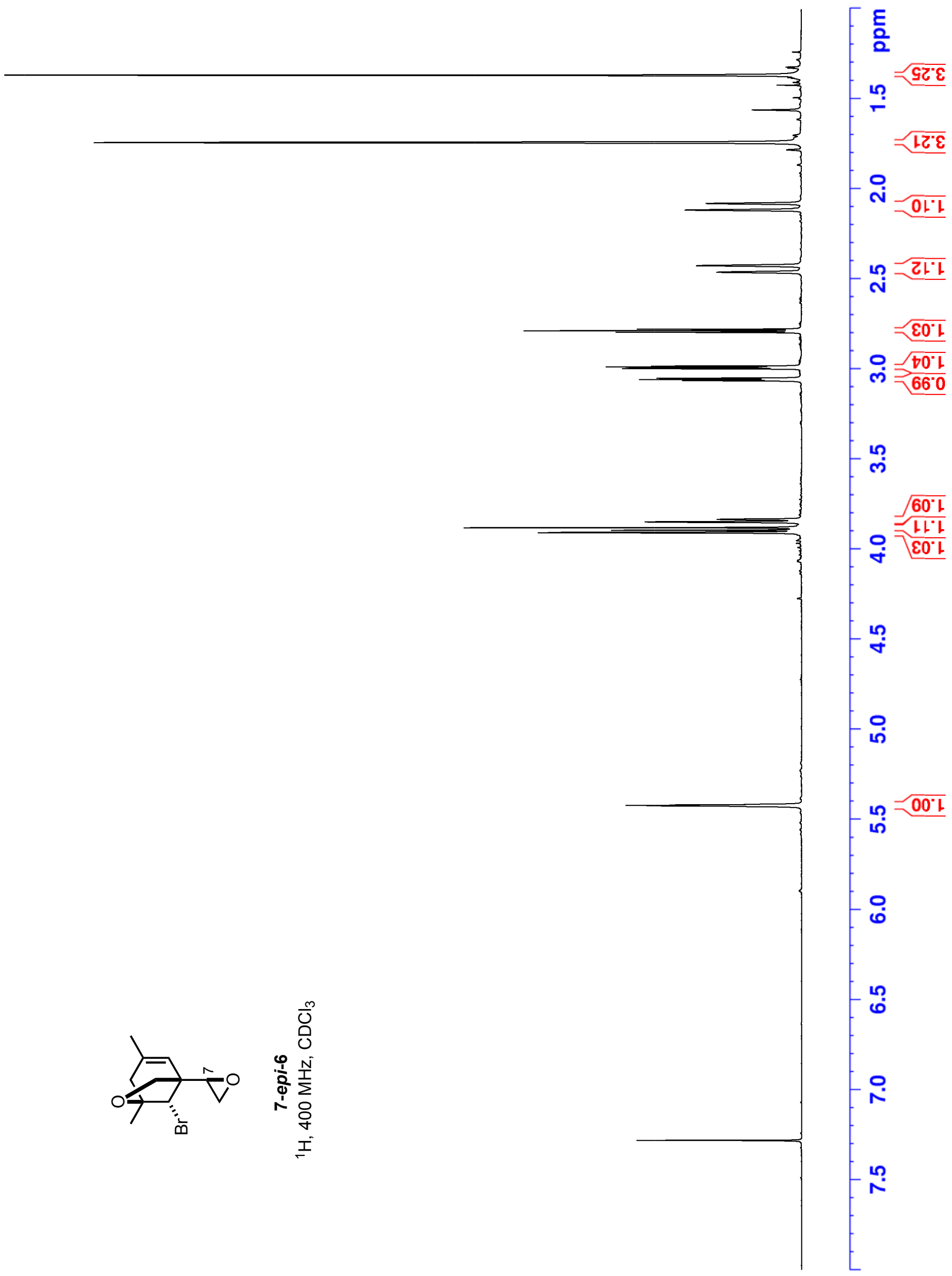




$$
1
$$




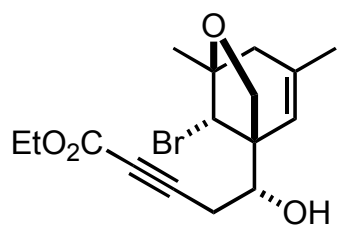

Alkynoate 10. To a solution of $1.51 \mathrm{~g}(15.4 \mathrm{mmol})$ of ethyl propiolate in $15 \mathrm{~mL}$ of freshly distilled tetrahydrofuran cooled to $-85^{\circ} \mathrm{C}$ (ethyl acetate-liquid nitrogen) was added $6.2 \mathrm{~mL}$ (15.4 mmol) of $2.5 \mathrm{M} \mathrm{n}$-butyllithium in hexanes and the mixture was stirred for $15 \mathrm{~min}$. To the solution was added $1.6 \mathrm{~mL}(1.74 \mathrm{~g}, 15.4 \mathrm{mmol})$ of borontrifluoride etherate via syringe followed by stirring for $15 \mathrm{~min}$. A solution of $2.17 \mathrm{~g}(7.7 \mathrm{mmol})$ of epoxide 6 in $3 \mathrm{~mL}$ of dry tetrahydrofuran was then added via cannula, followed by one $2 \mathrm{~mL}$ tetrahydrofuran rinse. The mixture was stirred for $3 \mathrm{~h}$ at $-70{ }^{\circ} \mathrm{C}$ (dry ice-acetone) and for $30 \mathrm{~min}$ at $0{ }^{\circ} \mathrm{C}$. The solution was poured into $10 \mathrm{~mL}$ of saturated aqueous sodium bicarbonate. The aqueous phase was extracted with three $20-\mathrm{mL}$ portions of diethyl ether. The combined organic phases were dried $\left(\mathrm{MgSO}_{4}\right)$, filtered, and concentrated in vacuo to give an amber oil. The amber oil was chromatographed over $150 \mathrm{~g}$ of silica gel (hexanes-ethyl acetate, $35: 1 \rightarrow 8: 1$ ) to afford $2.76 \mathrm{~g}$ (57\%) of alkynoate 10 as a white crystalline solid after trituration with $2 \mathrm{~mL}$ of pentane: $\mathrm{mp}$ 98-99 ${ }^{\circ} \mathrm{C}$; IR (thin film) 3385, 2232, $1707 \mathrm{~cm}^{-1} ;{ }^{1} \mathrm{H} \mathrm{NMR}\left(\mathrm{CDCl}_{3}, 500 \mathrm{MHz}\right) \delta 1.33(\mathrm{t}, J=7.3 \mathrm{~Hz}$, $\left.3 \mathrm{H}, \mathrm{CH}_{2} \mathrm{CH}_{3}\right), 1.38\left(\mathrm{~s}, 3 \mathrm{H}, \mathrm{CH}_{3}\right), 1.72\left(\mathrm{~s}, 3 \mathrm{H},=\mathrm{CCH}_{3}\right), 2.18$ and $2.33(\mathrm{ABq}, J=18.3 \mathrm{~Hz}, 2 \mathrm{H}$, $\mathrm{CH}_{2}$ ), 2.28 (br s, $1 \mathrm{H}, \mathrm{OH}$ ), 2.40 (dd, $J=17.5,9.5 \mathrm{~Hz}, 1 \mathrm{H}, \mathrm{C}_{2} \mathrm{CHOH}$ ), 2.85 (dd, $J=17.3,2.7$ $\left.\mathrm{Hz}, 1 \mathrm{H}, \mathrm{CH}_{2} \mathrm{CHOH}\right), 3.89$ and $3.99\left(\mathrm{ABq}, J=6.8 \mathrm{~Hz}, 2 \mathrm{H}, \mathrm{CH}_{2} \mathrm{O}\right), 4.00(\mathrm{q}, J=4.2 \mathrm{~Hz}, 1 \mathrm{H}$, C바), $4.23(\mathrm{~d}, J=1.0 \mathrm{~Hz}, 1 \mathrm{H}, \mathrm{CHBr}), 4.25\left(\mathrm{q}, J=7.3 \mathrm{~Hz}, 2 \mathrm{H}, \mathrm{OC}_{2} \mathrm{CH}_{3}\right), 5.30(\mathrm{t}, J=1.5 \mathrm{~Hz}$, $1 \mathrm{H},=\mathrm{CH}) ;{ }^{13} \mathrm{C} \mathrm{NMR}\left(\mathrm{CDCl}_{3}, 125 \mathrm{MHz}\right) \delta 14.0(\mathrm{q}), 22.1(\mathrm{q}), 23.1(\mathrm{q}), 23.5(\mathrm{t}), 43.8(\mathrm{t}), 51.8(\mathrm{~s})$, 
$55.5(d), 62.1(t), 69.1(d), 74.0(t), 75.1(s), 81.0(s), 85.6(s), 121.3(d), 136.7(s), 153.4(s)$; exact mass calcd. for $\mathrm{C}_{16} \mathrm{H}_{21} \mathrm{BrO}_{5}(\mathrm{M}+\mathrm{Na})^{+} \mathrm{m} / \mathrm{z} 379.0521$, found $\mathrm{m} / \mathrm{z}$ 379.0541. Anal. Calcd for $\mathrm{C}_{16} \mathrm{H}_{21} \mathrm{BrO}_{4}$ : C, 53.79; $\mathrm{H}$, 5.93. Found: C, 53.91; H, 5.93. 


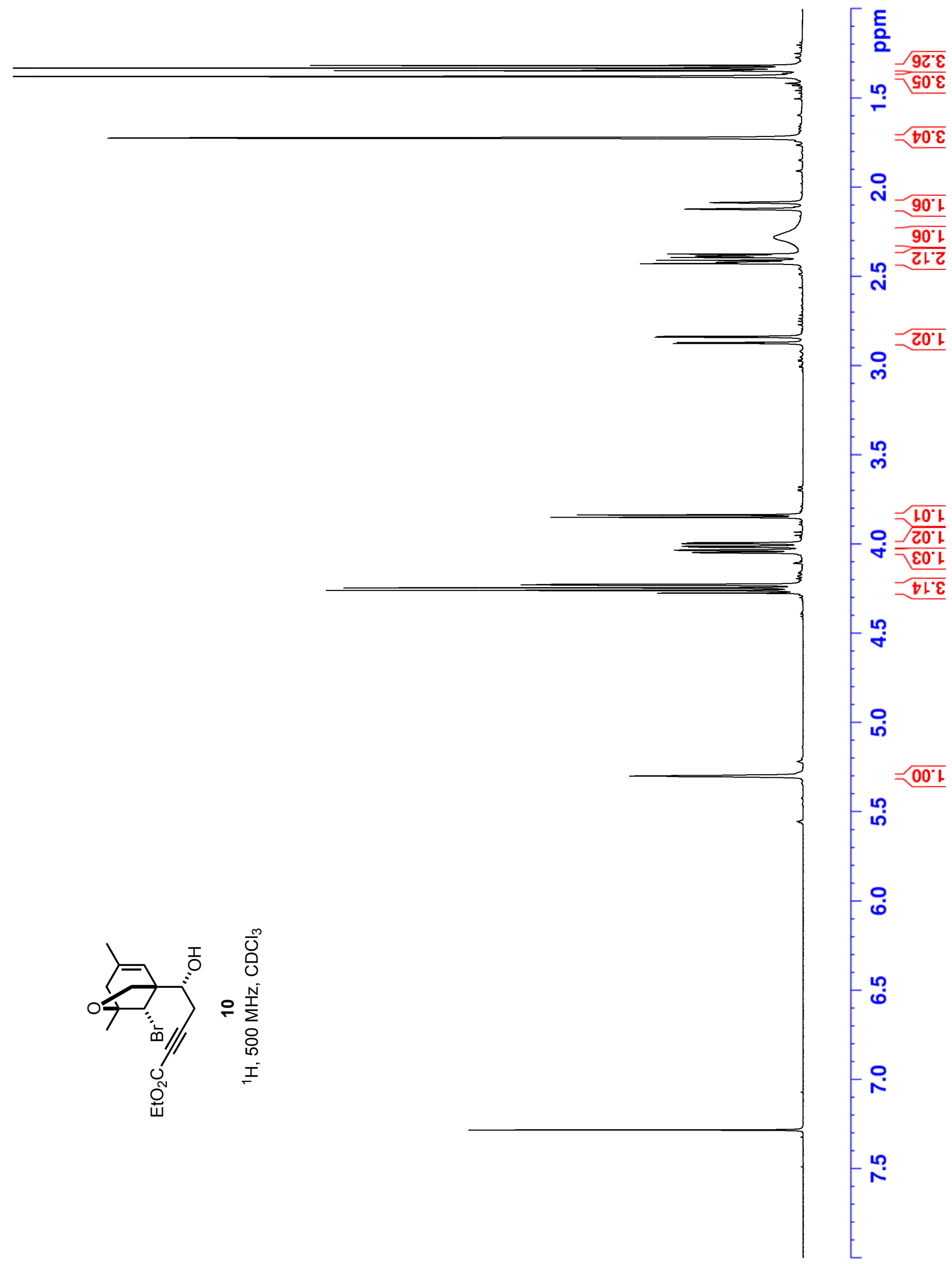




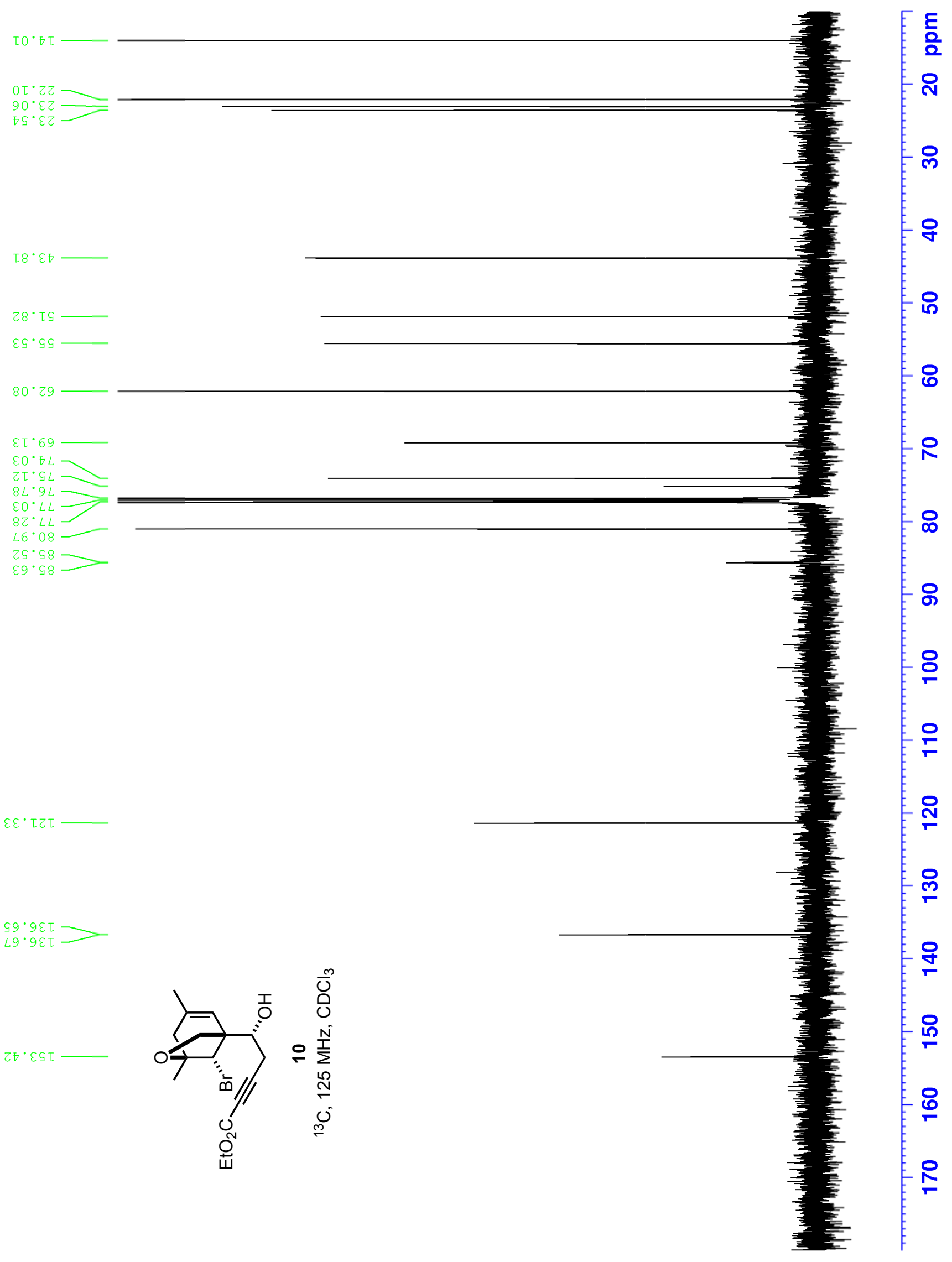




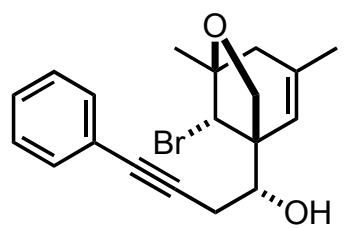

11

Phenylacetylide 11. To a solution of $718 \mu \mathrm{L}$ (668 mg, $6.54 \mathrm{mmol}$ ) of phenylacetylene in $12 \mathrm{~mL}$ of freshly distilled tetrahydrofuran cooled to $-86{ }^{\circ} \mathrm{C}$ (ethyl acetate-liquid nitrogen) was added $2.6 \mathrm{~mL}(6.54 \mathrm{mmol})$ of $2.5 \mathrm{M} \mathrm{n}$-butyllithium in hexanes. The mixture was stirred for $30 \mathrm{~min}$ at $-86{ }^{\circ} \mathrm{C}$, followed by $1 \mathrm{~h}$ at $-65^{\circ} \mathrm{C}$ (dry ice-acetone). To the solution was added $659 \mu \mathrm{L}$ (738 $\mathrm{mg}$, $6.54 \mathrm{mmol}$ ) of borontrifluoride etherate via syringe followed by stirring for $15 \mathrm{~min}$. A solution of $1.54 \mathrm{~g}(5.94 \mathrm{mmol})$ of epoxide 6 in $3 \mathrm{~mL}$ of dry tetrahydrofuran was then added via cannula. The mixture was stirred for $3 \mathrm{~h}$ at $-65^{\circ} \mathrm{C}$ (dry ice-acetone). The solution was poured into 20 $\mathrm{mL}$ of saturated aqueous sodium bicarbonate. The aqueous phase was extracted with two 10- $\mathrm{mL}$ portions of diethyl ether. The combined organic phases were dried $\left(\mathrm{MgSO}_{4}\right)$, filtered, and concentrated in vacuo. The residual pale yellow solid was triturated with ethyl acetate to afford $0.93 \mathrm{~g}(43 \%)$ of phenyl acetylide 11 as a white crystalline solid: $\mathrm{mp} 127-129^{\circ} \mathrm{C}$; IR (thin film) 3401, $2356 \mathrm{~cm}^{-1} ;{ }^{1} \mathrm{H}$ NMR (acetone- $\left.\mathrm{d}_{6}, 500 \mathrm{MHz}\right) \delta 1.31\left(\mathrm{~s}, 3 \mathrm{H}, \mathrm{CH}_{3}\right), 1.71\left(\mathrm{~s}, 3 \mathrm{H},=\mathrm{CCH}_{3}\right)$, 2.16 and $2.30\left(\mathrm{ABq}, J=18.0 \mathrm{~Hz}, 2 \mathrm{H}, \mathrm{CH}_{2}\right), 2.56\left(\mathrm{dd}, J=17.0,8.0 \mathrm{~Hz}, 1 \mathrm{H}, \mathrm{CH}_{2} \mathrm{CHOH}\right), 2.93$ (dd, $J=17.2,3.2 \mathrm{~Hz}, 1 \mathrm{H}, \mathrm{CH}_{2} \mathrm{CHOH}$ ), $3.88\left(\mathrm{~d}, J=7.0 \mathrm{~Hz}, 1 \mathrm{H}, \mathrm{CH}_{2} \mathrm{O}\right.$ ), 3.98 (ddd, $J=8.2,5.2$, 3. $3 \mathrm{~Hz}, 1 \mathrm{H}, \mathrm{CHOH}), 4.12\left(\mathrm{~d}, J=7.0 \mathrm{~Hz}, 1 \mathrm{H}, \mathrm{CH}_{2} \mathrm{O}\right), 4.37(\mathrm{~s}, 1 \mathrm{H}, \mathrm{CHBr}), 4.64(\mathrm{~d}, J=5.5 \mathrm{~Hz}, 1 \mathrm{H}$, $\mathrm{OH}), 5.58(\mathrm{~s}, 1 \mathrm{H},=\mathrm{CH}), 7.34-7.36(\mathrm{~m}, 3 \mathrm{H}, \mathrm{ArH}), 7.42-7.44(\mathrm{~m}, 2 \mathrm{H}, \mathrm{ArH}) ;{ }^{13} \mathrm{C}$ NMR (acetone- $\mathrm{d}_{6}$, $500 \mathrm{MHz}) \delta 21.4(\mathrm{q}), 22.6(\mathrm{q}), 23.8(\mathrm{t}), 43.8(\mathrm{t}), 52.3(\mathrm{~s}), 56.8(\mathrm{~d}), 68.9(\mathrm{~d}), 73.5(\mathrm{t}), 80.0(\mathrm{~s})$, 81.8 (s), 87.7 (s), 123.1 (d), 123.9 (s), 127.8 (d), 128.3 (d), 131.4 (d), 135.3 (s); exact mass 
calcd. for $\mathrm{C}_{19} \mathrm{H}_{21} \mathrm{BrO}_{2}(\mathrm{M}+\mathrm{Na})^{+} \mathrm{m} / \mathrm{z} 383.0623$, found $\mathrm{m} / \mathrm{z}$ 383.0626. 


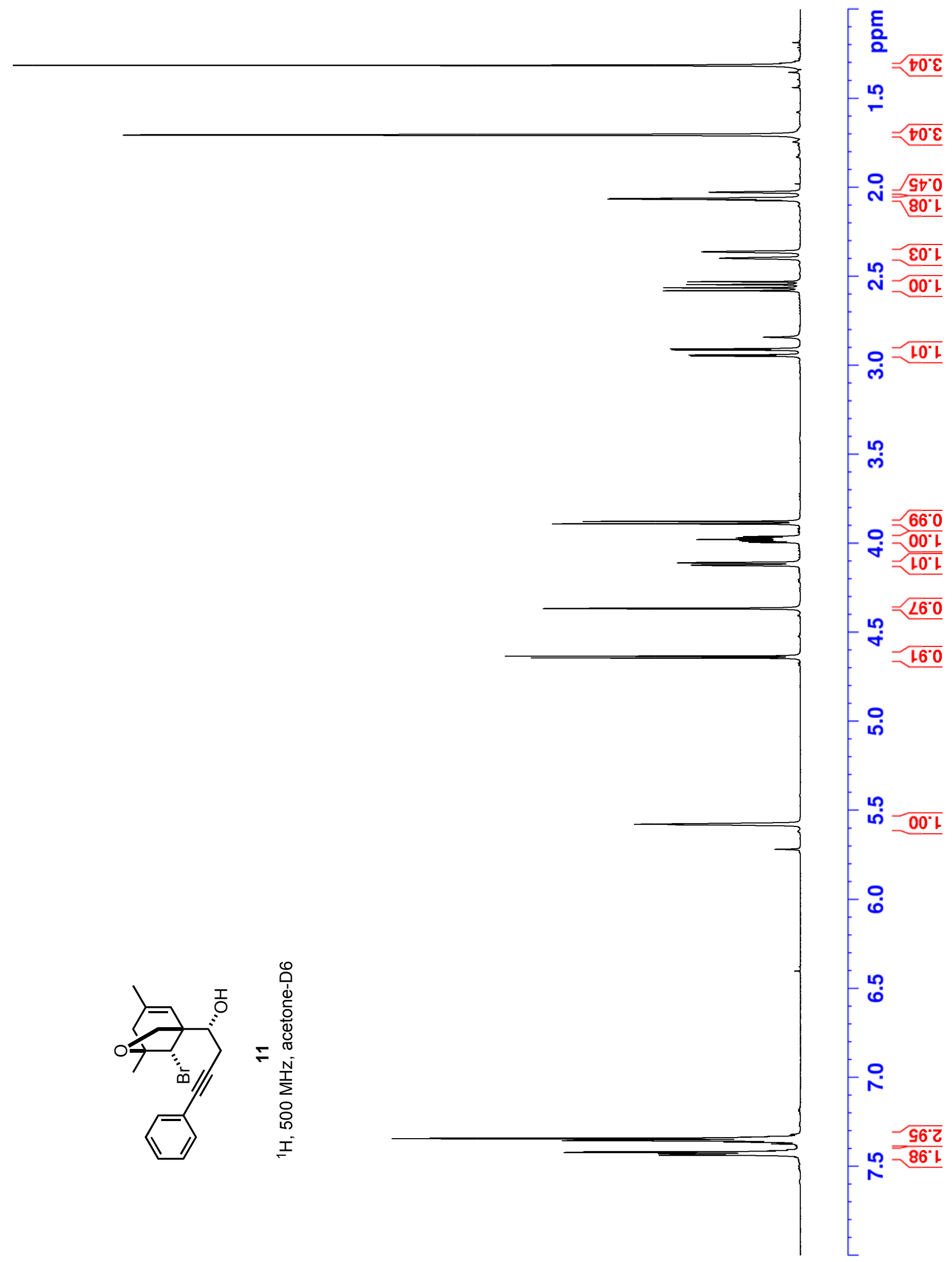




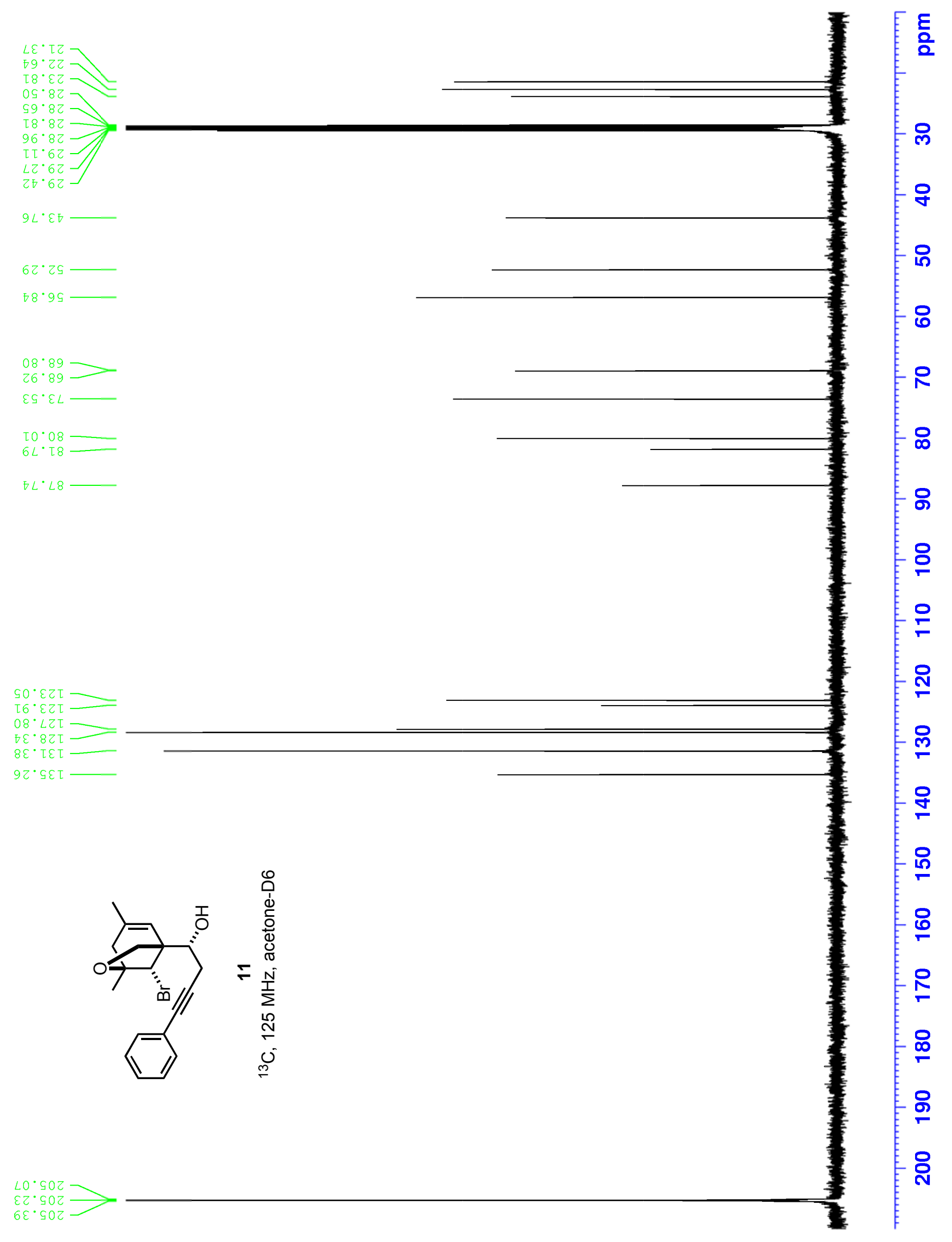




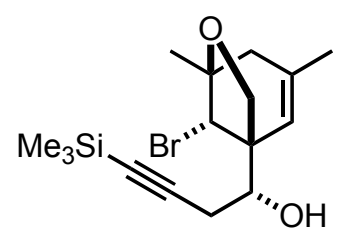

12

TMS acetylide 12. To a solution of $15.1 \mathrm{~mL}(10.5 \mathrm{~g}, 61.6 \mathrm{mmol})$ of trimethylsilylacetylene in 40 $\mathrm{mL}$ of freshly distilled tetrahydrofuran cooled to $-65^{\circ} \mathrm{C}$ (dry ice-acetone) was added $24.6 \mathrm{~mL}$ (61.6 mmol) of $2.5 \mathrm{M} \mathrm{n}$-butyllithium in hexanes and the mixture was stirred for $15 \mathrm{~min}$. To the solution was added $6.2 \mathrm{~mL}(6.9 \mathrm{~g}, 61.6 \mathrm{mmol})$ of borontrifluoride etherate via syringe followed by stirring for $15 \mathrm{~min}$. A solution of $5.32 \mathrm{~g}(20.5 \mathrm{mmol})$ of epoxide 6 in $10 \mathrm{~mL}$ of dry tetrahydrofuran was then added via cannula. The mixture was stirred for $1 \mathrm{~h}$ at $-65{ }^{\circ} \mathrm{C}$ (dry ice-acetone). The solution was poured into $50 \mathrm{~mL}$ of saturated aqueous sodium bicarbonate. The aqueous phase was extracted with three $50-\mathrm{mL}$ portions of diethyl ether. The combined organic phases were dried $\left(\mathrm{MgSO}_{4}\right)$, filtered, and concentrated in vacuo. The residual pale orange oil was chromatographed over $130 \mathrm{~g}$ of silica gel (hexanes-ethyl acetate, $6: 1$ ) to afford $6.9 \mathrm{~g}$ (94\%) of TMS acetylide 12 as a pale yellow crystalline solid: $\mathrm{mp} 84-87^{\circ} \mathrm{C}$; IR (thin film) 3420, 2175, $1666 \mathrm{~cm}^{-1} ;{ }^{1} \mathrm{H} \mathrm{NMR}\left(\mathrm{CDCl}_{3}, 500 \mathrm{MHz}\right) \delta 0.18\left(\mathrm{~s}, 9 \mathrm{H}, \mathrm{Si}\left(\mathrm{CH}_{3}\right)_{3}\right), 1.38\left(\mathrm{~s}, 3 \mathrm{H}, \mathrm{CH}_{3}\right)$, $1.72\left(\mathrm{~s}, 3 \mathrm{H},=\mathrm{CCH}_{3}\right), 2.17$ and $2.32\left(\mathrm{ABq}, J=18.0 \mathrm{~Hz}, 2 \mathrm{H}, \mathrm{CH}_{2}\right), 2.32(\mathrm{br} \mathrm{s}, 1 \mathrm{H}, \mathrm{OH}), 2.33(\mathrm{dd}$, $\left.J=17.0,9.0 \mathrm{~Hz}, 1 \mathrm{H}, \mathrm{C}_{2} \mathrm{CHOH}\right), 2.75\left(\mathrm{dd}, J=17.0,3.0 \mathrm{~Hz}, 1 \mathrm{H}, \mathrm{C}_{2} \mathrm{CHOH}\right), 3.89$ and 4.00 (ABq, $J=6.8 \mathrm{~Hz}, 2 \mathrm{H}, \mathrm{CH}_{2} \mathrm{O}$ ), $3.89(\mathrm{dd}, J=9.0,3.0 \mathrm{~Hz}, 1 \mathrm{H}, \mathrm{C} \underline{\mathrm{HOH}}), 4.26(\mathrm{~s}, 1 \mathrm{H}, \mathrm{CHBr}$ ), $5.33(\mathrm{~s}$, $1 \mathrm{H},=\mathrm{CH}) ;{ }^{13} \mathrm{C} \mathrm{NMR}\left(\mathrm{CDCl}_{3}, 125 \mathrm{MHz}\right) \delta 0.0(\mathrm{q}), 22.1(\mathrm{q}), 23.1(\mathrm{q}), 24.5(\mathrm{t}), 43.8(\mathrm{t}), 51.7(\mathrm{~s})$ $55.8(d), 69.0(d), 74.0(t), 80.8(s), 88.6(s), 102.5(s), 121.8(d), 136.2(s)$; exact mass calcd. for $\mathrm{C}_{16} \mathrm{H}_{25} \mathrm{BrO}_{2} \mathrm{Si}(\mathrm{M}+\mathrm{Na})^{+} \mathrm{m} / \mathrm{z}$ 379.0705, found $\mathrm{m} / \mathrm{z}$ 379.0708. Anal. Calcd for $\mathrm{C}_{16} \mathrm{H}_{25}{ }^{79} \mathrm{BrO} \mathrm{Si}_{2} \mathrm{Si}$ 
C, 53.78; H, 7.05. Found: C, 53.93; H, 7.08. 


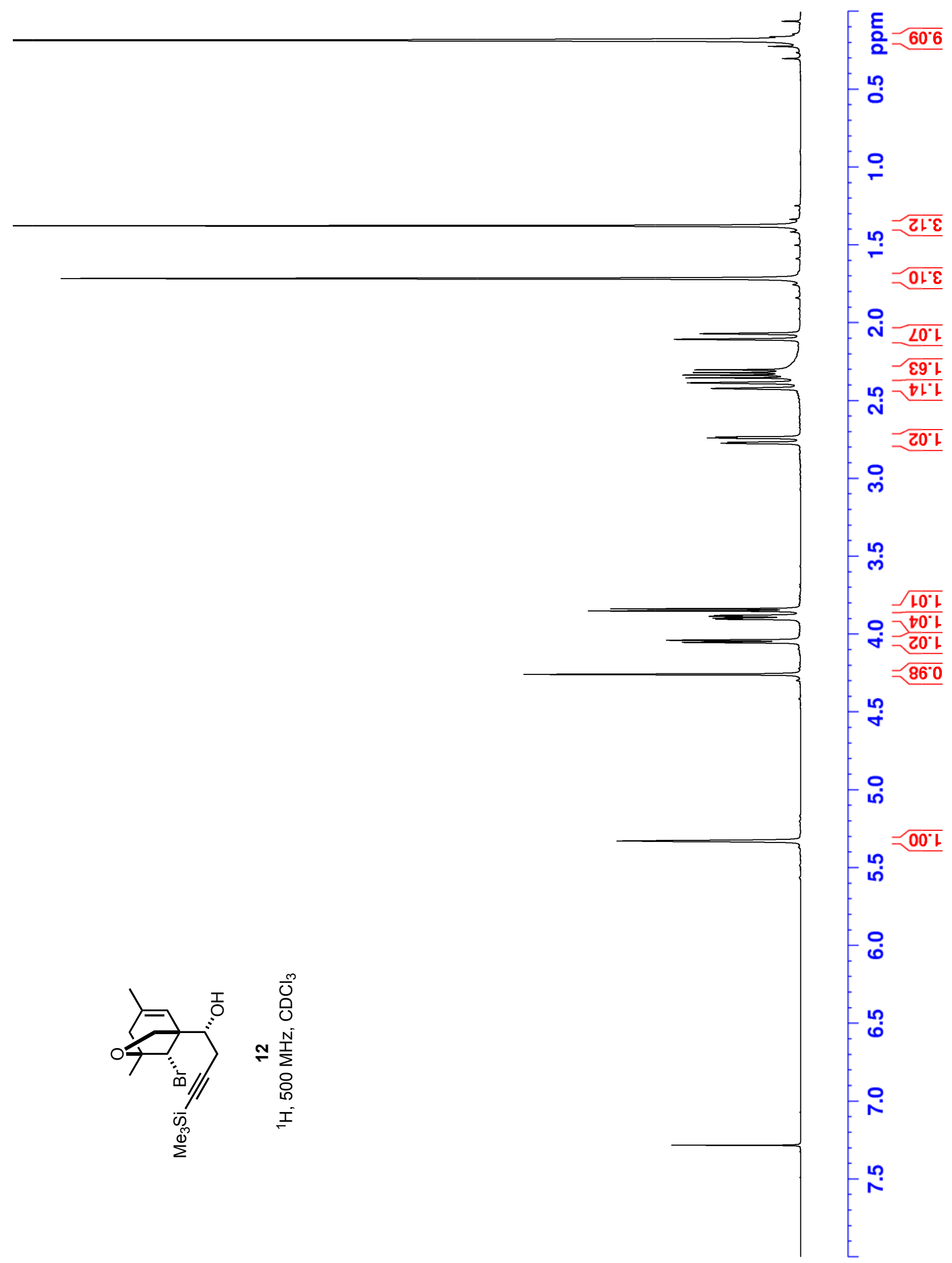




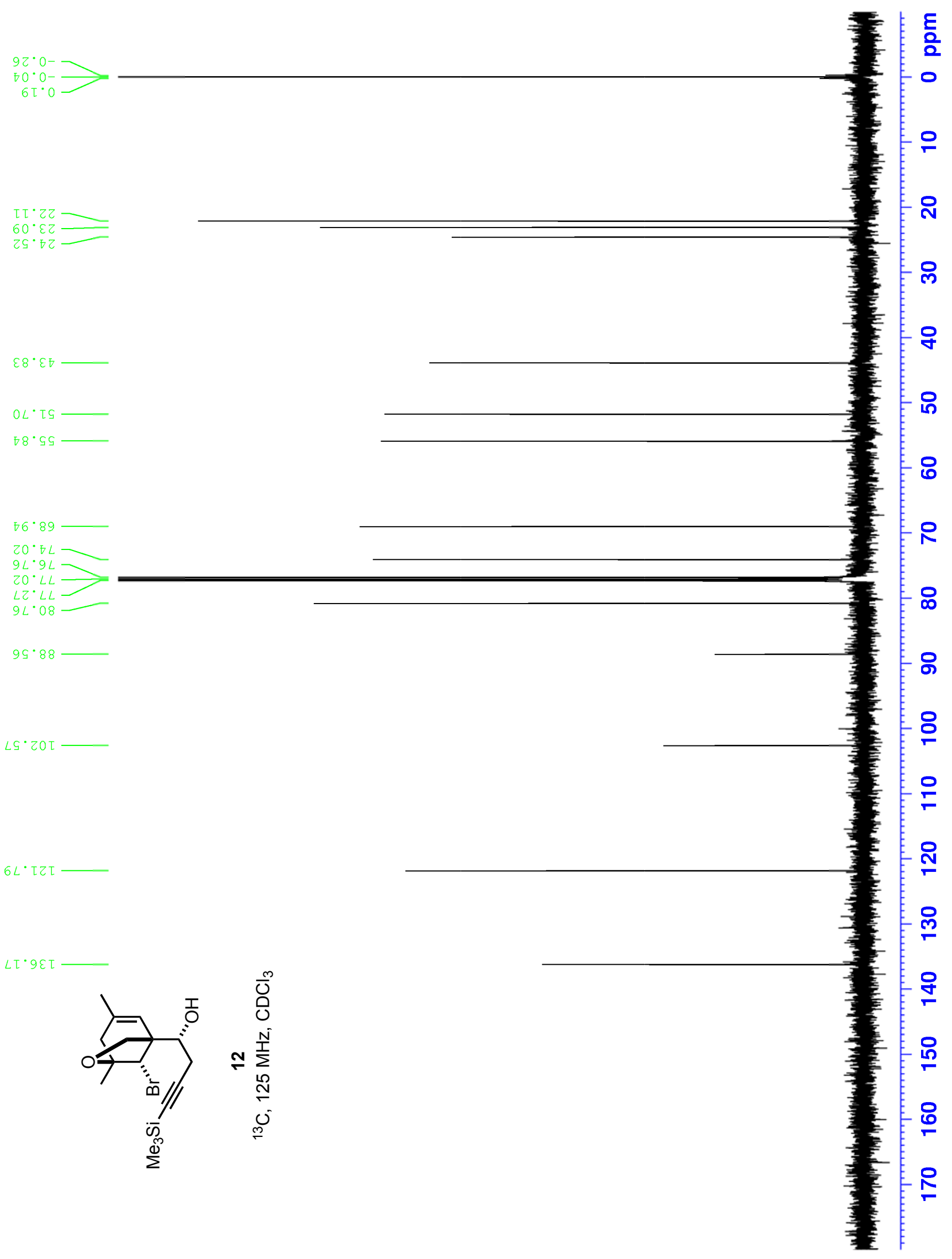




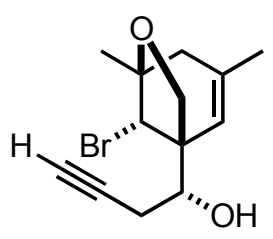

13

Terminal acetylide 13. To a solution of $357 \mathrm{mg}(1.00 \mathrm{mmol})$ of TMS-alkyne $12 \mathrm{in} 8 \mathrm{~mL}$ of freshly distilled tetrahydrofuran at $\mathrm{rt}$ was added $1.25 \mathrm{~mL}(1.25 \mathrm{mmol})$ of $1.0 \mathrm{M}$ tetra- $n$-butylammonium fluoride in tetrahydrofuran and the mixture was stirred for $20 \mathrm{~min}$. The solution was poured into $10 \mathrm{~mL}$ of distilled water. The aqueous phase was extracted with three 10-mL portions of diethyl ether. The combined organic phases were dried $\left(\mathrm{MgSO}_{4}\right)$, filtered, and concentrated in vacuo. The residual tan solid was chromatographed over $2 \mathrm{~g}$ of silica gel (hexanes-ethyl acetate, 20:1) to afford $232 \mathrm{mg}(81 \%)$ of acetylide 13 as a white crystalline solid: $\mathrm{mp} 98-100^{\circ} \mathrm{C}$; IR (thin film) 3374, 3300, $2353 \mathrm{~cm}^{-1} ;{ }^{1} \mathrm{H}$ NMR $\left(\mathrm{CDCl}_{3}, 500 \mathrm{MHz}\right) \delta 1.35$ (s, $\left.3 \mathrm{H}, \mathrm{CH}_{3}\right), 1.69\left(\mathrm{~s}, 3 \mathrm{H},=\mathrm{CCH}_{3}\right), 2.14$ and $2.29\left(\mathrm{ABq}, J=18.3 \mathrm{~Hz}, 2 \mathrm{H}, \mathrm{CH}_{2}\right), 2.10(\mathrm{t}, J=2.5 \mathrm{~Hz}$, $1 \mathrm{H}, \mathrm{C} \equiv \mathrm{CH}$ ), 2.22 (ddd, $J=17.0,9.5,2.5 \mathrm{~Hz}, 1 \mathrm{H}, \mathrm{CH}_{2} \mathrm{CHOH}$ ), 2.68 (app dt, $J=17.0,3.0 \mathrm{~Hz}, 1 \mathrm{H}$, $\left.\mathrm{C}_{2} \mathrm{CHOH}\right), 2.70(\mathrm{br} \mathrm{s}, 1 \mathrm{H}, \mathrm{OH}), 3.81\left(\mathrm{~d}, J=6.5 \mathrm{~Hz}, 1 \mathrm{H}, \mathrm{CH}_{2} \mathrm{O}\right), 3.88(\mathrm{dt}, J=9.5,3.0 \mathrm{~Hz}, 1 \mathrm{H}$,

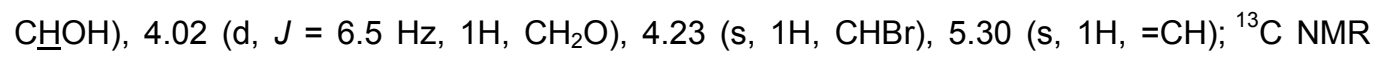
$\left(\mathrm{CDCl}_{3}, 125 \mathrm{MHz}\right) \delta 22.1(\mathrm{q}), 23.1(\mathrm{q}), 23.2(\mathrm{t}), 43.8(\mathrm{t}), 51.7(\mathrm{~s}), 55.8(\mathrm{~d}), 69.2(\mathrm{~d}), 71.3(\mathrm{~d})$ 74.0 (t), 80.9 (s), 81.0 (s), 121.8 (d), 136.2 (s); exact mass calcd. for $\mathrm{C}_{13} \mathrm{H}_{17}{ }^{79} \mathrm{BrO}(\mathrm{M}+\mathrm{Na})^{+}$ m/z 307.0310, found $m / z$ 307.0309. Anal. Calcd for $\mathrm{C}_{13} \mathrm{H}_{17} \mathrm{BrO}_{2}$ : C, 54.75; $\mathrm{H}, 6.01$. Found: $\mathrm{C}$, $54.75 ; \mathrm{H}, 6.13$. 


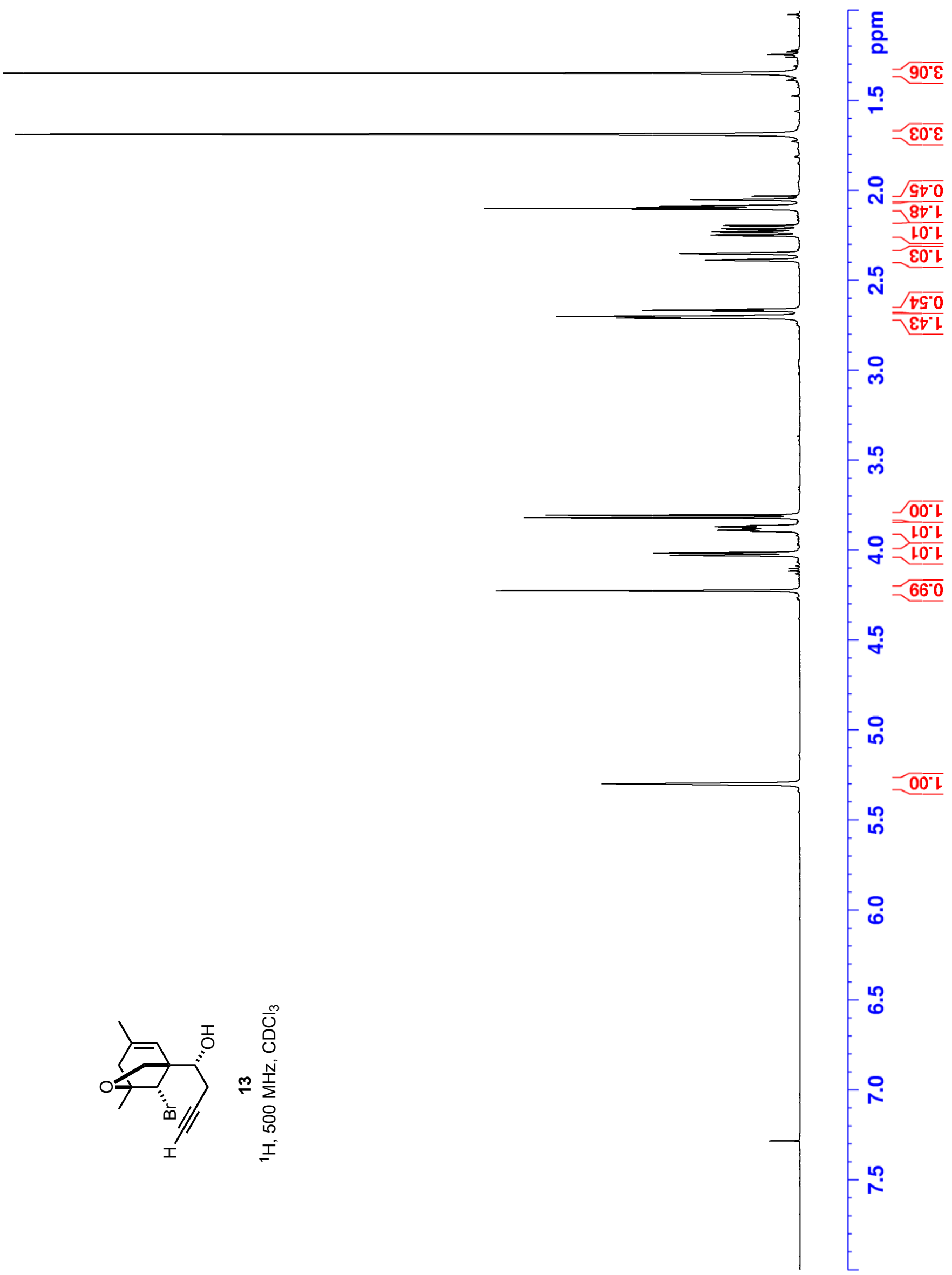




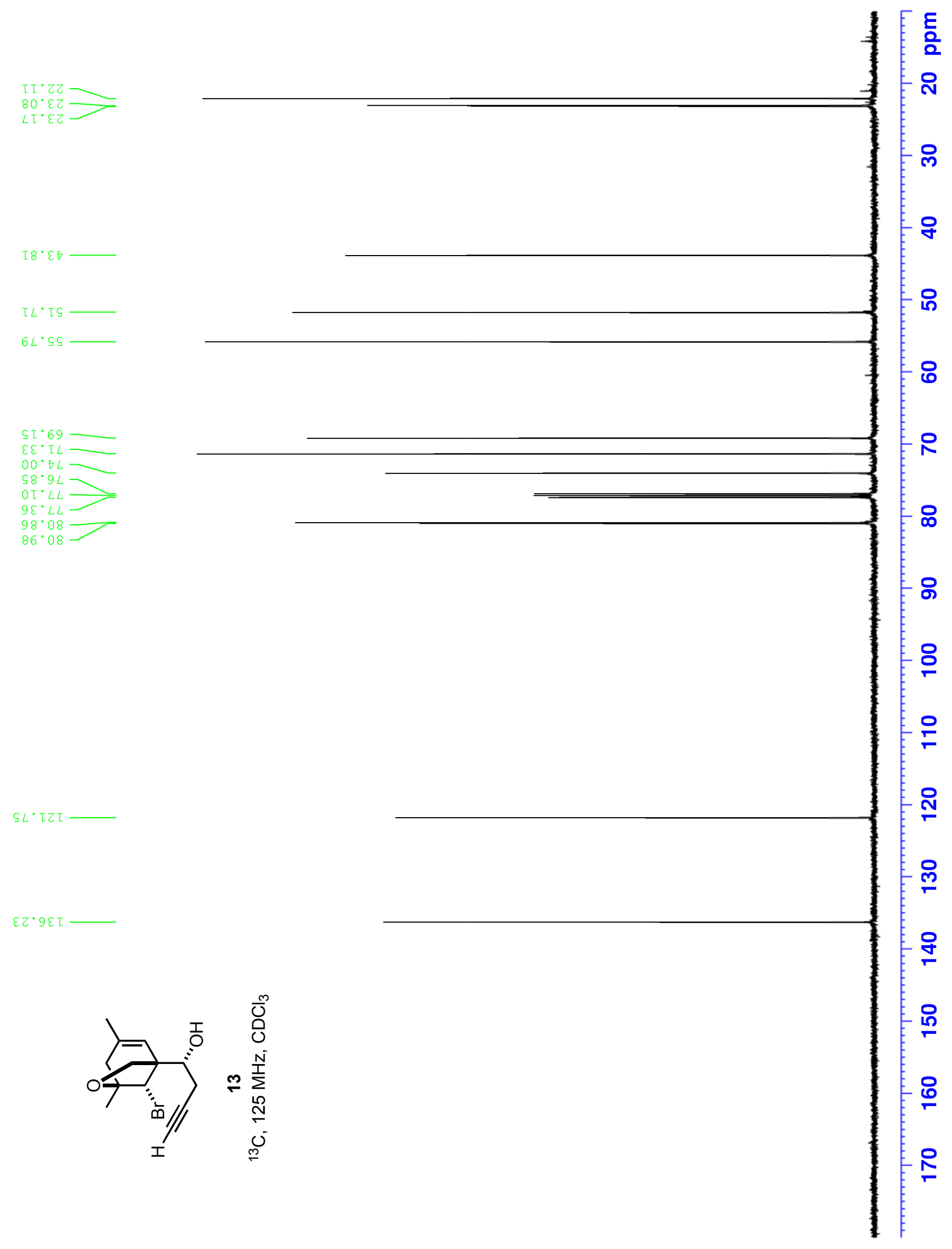




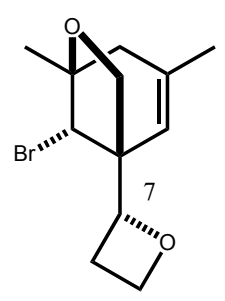

14

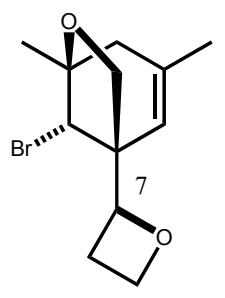

7-epi-14

Oxetanes 14 and 7-epi-14. To a solution of $8.62 \mathrm{~g}(39.2 \mathrm{mmol})$ of trimethyloxylsulfonium iodide in $80 \mathrm{~mL}$ of $t$-BuOH was added a solution of $4.39 \mathrm{~g}(39.2 \mathrm{mmol})$ of $t-\mathrm{BuOK}$ in $50 \mathrm{~mL}$ of $t$ - $\mathrm{BuOH}$ under $\mathrm{N}_{2}$ at rt. The mixture was warmed at $50{ }^{\circ} \mathrm{C}$ for 30 min during which time the reaction mixture became milky. A solution of $2.40 \mathrm{~g}(9.80 \mathrm{mmol})$ of aldehyde 5 in $20 \mathrm{~mL}$ of $t$-BuOH was added by addition funnel followed by a $5 \mathrm{~mL} t$-BuOH rinse. The resulting suspension was stirred for $3 \mathrm{~d}$, concentrated in vacuo, washed with $30 \mathrm{~mL}$ of $\mathrm{H}_{2} \mathrm{O}$, and extracted with three $50-\mathrm{mL}$ portions of $\mathrm{CH}_{2} \mathrm{Cl}_{2}$. The combined organic extracts were dried $\left(\mathrm{Na}_{2} \mathrm{SO}_{4}\right)$ and concentrated in vacuo. The residual colorless oil was purified by chromatography over $50 \mathrm{~g}$ of silica gel (hexanes-ethyl acetate, $10: 1)$ to afford $2.27 \mathrm{~g}(85 \%)$ of a 1:1 mixture of oxetanes $\mathbf{1 4}$ and $\mathbf{7 - e p i - 1 4}$ as a colorless oil. A combination of $1 \mathrm{D}$ and $2 \mathrm{D}$ NMR experiments were used to extract the following NMR assignments for each isomer. IR and MS data were collected on the mixture. Oxetane 14: IR (neat) 2969, $1665 \mathrm{~cm}^{-1} ;{ }^{1} \mathrm{H}$ NMR $\left(\mathrm{CDCl}_{3}, 500 \mathrm{MHz}\right) \delta 1.37\left(\mathrm{~s}, 3 \mathrm{H}, \mathrm{CH}_{3}\right), 1.74\left(\mathrm{~s}, 3 \mathrm{H}, \mathrm{CH}_{3}\right), 2.10\left(\mathrm{~d}, \mathrm{~J}=18.0 \mathrm{~Hz}, 1 \mathrm{H}, \mathrm{CH}_{2}\right), 2.43$ (d, $\left.J=18.0 \mathrm{~Hz}, 1 \mathrm{H}, \mathrm{CH}_{2}\right), 2.55\left(\mathrm{~m}, 1 \mathrm{H}, \mathrm{C}_{8} \mathrm{H}\right), 2.72\left(\mathrm{~m}, 1 \mathrm{H}, \mathrm{C}_{8} \mathrm{H}\right), 4.05$ and $4.18(\mathrm{ABq}, J=6.5$ $\left.\mathrm{Hz}, 2 \mathrm{H}, \mathrm{CH}_{2} \mathrm{O}\right), 3.98(\mathrm{~s}, 1 \mathrm{H}, \mathrm{CHBr}), 4.48\left(\mathrm{~m}, 1 \mathrm{H}, \mathrm{C}_{9} \mathrm{H}\right), 4.76\left(\mathrm{~m}, 1 \mathrm{H}, \mathrm{C}_{9} \mathrm{H}\right), 4.96(\mathrm{t}, J=8.0 \mathrm{~Hz}$, $\left.1 \mathrm{H}, \mathrm{C}_{7} \mathrm{H}\right), 5.38(\mathrm{~s}, 1 \mathrm{H},=\mathrm{CH}) ;{ }^{13} \mathrm{C} \mathrm{NMR}\left(\mathrm{CDCl}_{3}, 125 \mathrm{MHz}\right) \delta 22.0(\mathrm{q}), 23.0$ (q), $23.7(\mathrm{t}), 43.8(\mathrm{t})$ $51.0(\mathrm{~s}), 53.8(\mathrm{~d}), 69.4(\mathrm{t}), 75.1(\mathrm{t}), 81.3(\mathrm{~s}), 81.4(\mathrm{~d}), 120.1(\mathrm{~d}), 135.8(\mathrm{~s})$; exact mass calcd. for $\mathrm{C}_{12} \mathrm{H}_{17}{ }^{79} \mathrm{BrO}_{2}(\mathrm{M}+\mathrm{Na})^{+} \mathrm{m} / \mathrm{z} 295.0310$, found $\mathrm{m} / \mathrm{z}$ 295.0307. Oxetane 7-epi-14: IR (neat) 2969, 
$1665 \mathrm{~cm}^{-1} ;{ }^{1} \mathrm{H}$ NMR $\left(\mathrm{CDCl}_{3}, 500 \mathrm{MHz}\right) \delta 1.36\left(\mathrm{~s}, 3 \mathrm{H}, \mathrm{CH}_{3}\right), 1.74\left(\mathrm{~s}, 3 \mathrm{H}, \mathrm{CH}_{3}\right), 2.11(\mathrm{~d}, J=18.0$ $\left.\mathrm{Hz}, 1 \mathrm{H}, \mathrm{CH}_{2}\right), 2.44\left(\mathrm{~d}, J=18.0 \mathrm{~Hz}, 1 \mathrm{H}, \mathrm{CH}_{2}\right), 2.66\left(\mathrm{~m}, 1 \mathrm{H}, \mathrm{C}_{8} \mathrm{H}\right), 2.84\left(\mathrm{~m}, 1 \mathrm{H}, \mathrm{C}_{8} \mathrm{H}\right), 3.87$ and $3.97\left(\mathrm{ABq}, J=7.0 \mathrm{~Hz}, 2 \mathrm{H}, \mathrm{CH}_{2} \mathrm{O}\right), 4.06(\mathrm{~s}, 1 \mathrm{H}, \mathrm{CHBr}), 4.57\left(\mathrm{~m}, 1 \mathrm{H}, \mathrm{C}_{9} \mathrm{H}\right), 4.75\left(\mathrm{~m}, 1 \mathrm{H}, \mathrm{C}_{9} \mathrm{H}\right)$, $4.96\left(\mathrm{t}, J=8.0 \mathrm{~Hz}, 1 \mathrm{H}, \mathrm{C}_{7} \mathrm{H}\right), 5.46(\mathrm{~s}, 1 \mathrm{H},=\mathrm{CH}) ;{ }^{13} \mathrm{C} \mathrm{NMR}\left(\mathrm{CDCl}_{3}, 125 \mathrm{MHz}\right) \delta 22.0(\mathrm{q}), 22.3(\mathrm{t})$, $22.9(\mathrm{q}), 43.7(\mathrm{t}), 51.8(\mathrm{~s}), 53.8(\mathrm{~d}), 69.0(\mathrm{t}), 75.3(\mathrm{t}), 81.9(\mathrm{~d}), 82.0(\mathrm{~s}), 121.3(\mathrm{~d}), 136.2(\mathrm{~s})$ exact mass calcd. for $\mathrm{C}_{12} \mathrm{H}_{17}{ }^{79} \mathrm{BrO}{ }_{2}(\mathrm{M}+\mathrm{Na})^{+} \mathrm{m} / \mathrm{z} 295.0310$, found $\mathrm{m} / \mathrm{z} 295.0307$. 


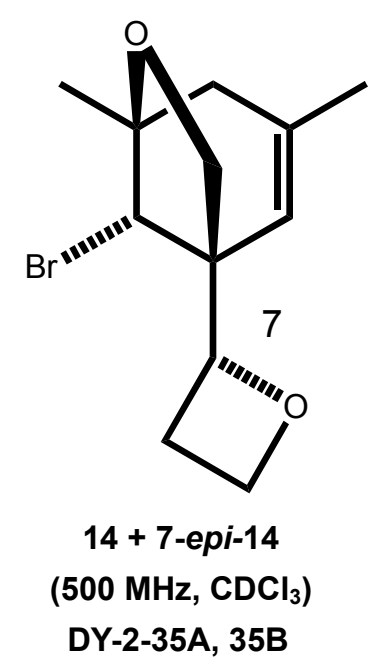

\section{MAnth I I I}

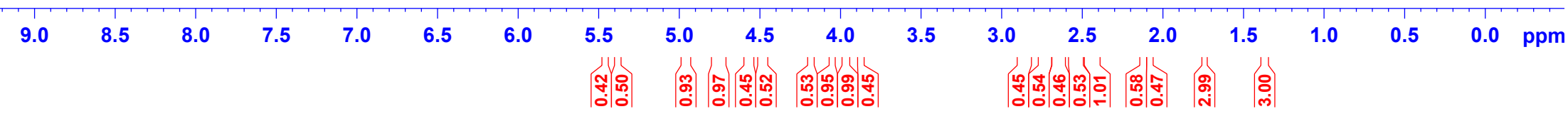




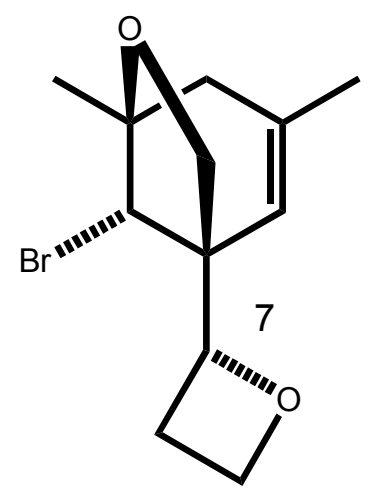

$14+7$-epi-14 ( $500 \mathrm{MHz}, \mathrm{CDCl}_{3}$ )

DY-2-35A, 35B

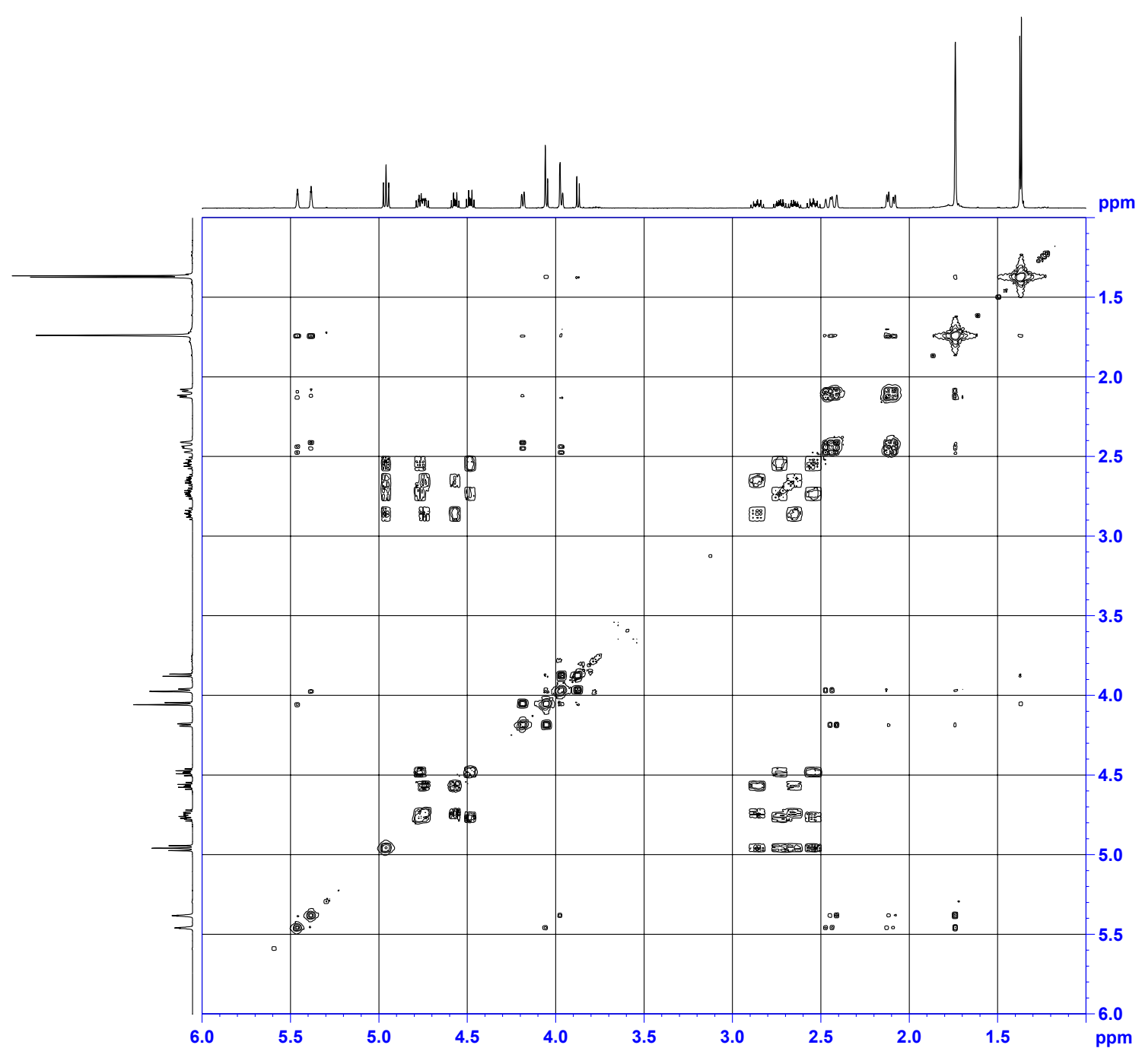




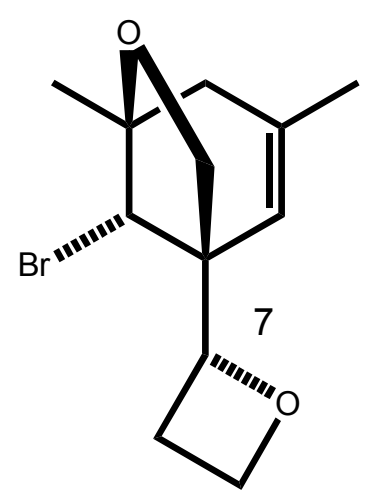

$14+7$-epi-14

(125 MHz, $\mathrm{CDCl}_{3}$ )

DY-2-35A, 35B

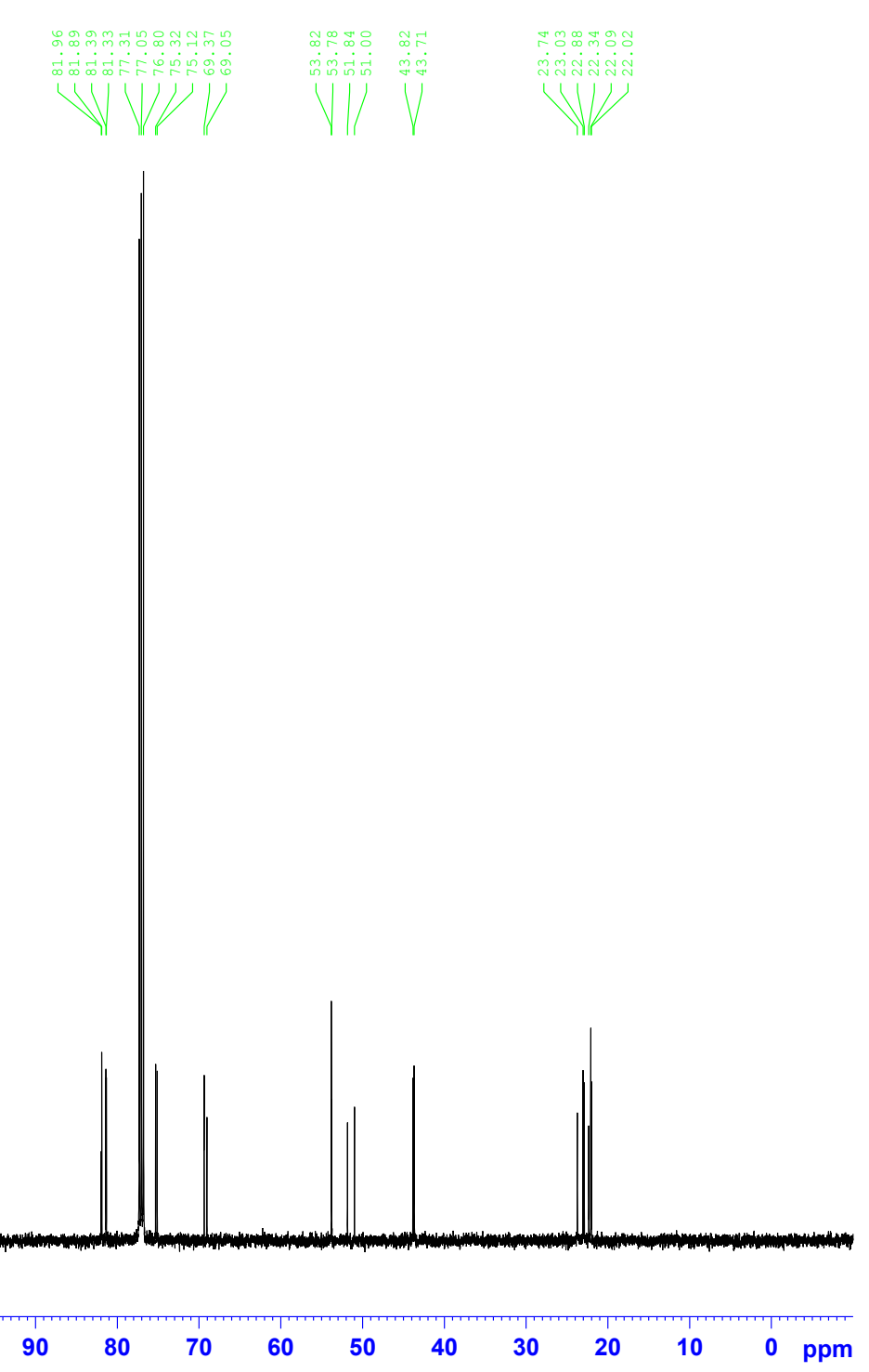




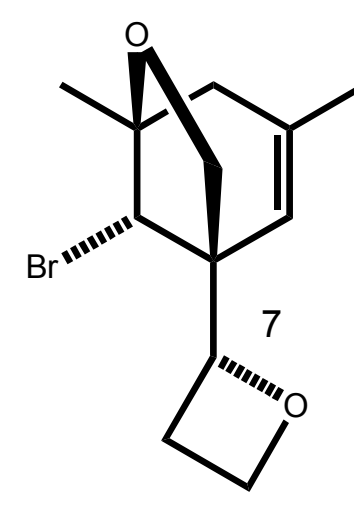

$14+7$-epi-14

(125 MHz, $\mathrm{CDCl}_{3}$ )

DY-2-35A, 35B

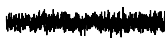
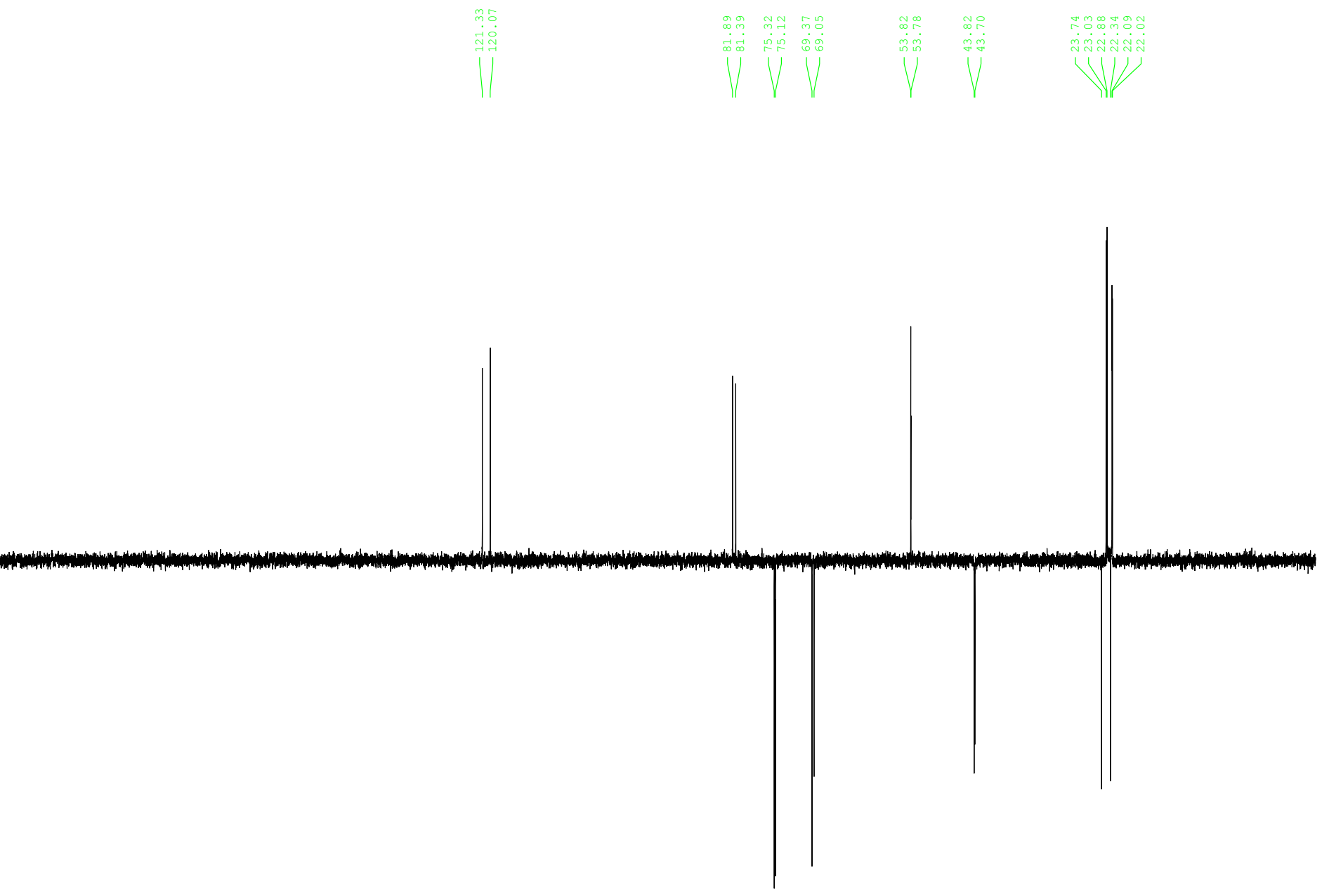


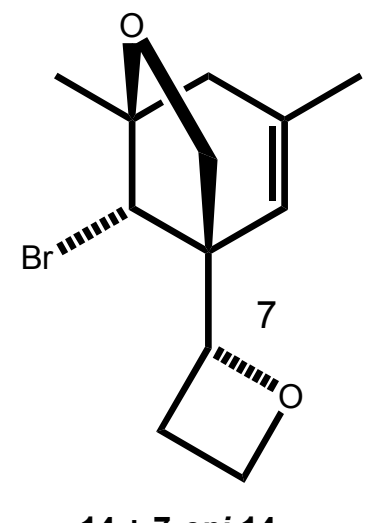

14 + 7-epi-14

$\left({ }^{13} \mathrm{C} 125 \mathrm{MHz}\right.$,

${ }^{1} \mathrm{H} 500 \mathrm{MHz}, \mathrm{CDCl}_{3}$ )

DY-2-35A, 35B

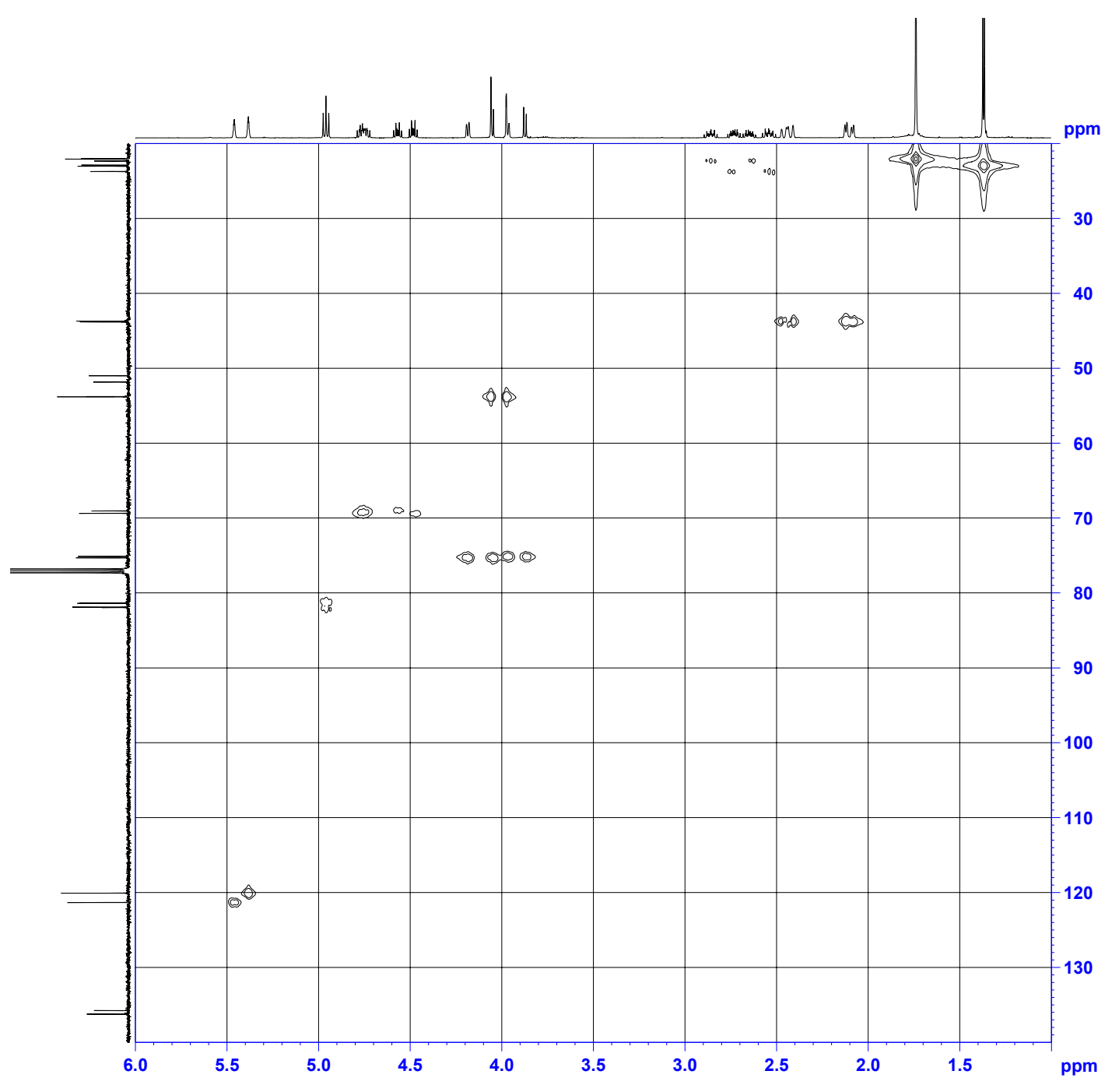




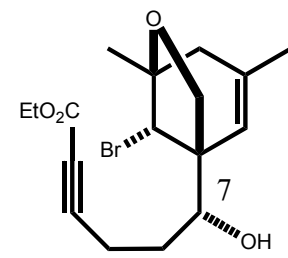

15

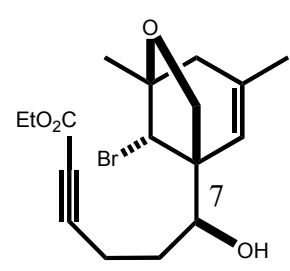

7-epi-15

Alkynes 15 and 7-epi-15. To a solution of $1.64 \mathrm{~g}(16.7 \mathrm{mmol})$ of ethyl propiolate in $15 \mathrm{~mL}$ of dry tetrahydrofuran cooled to $-85^{\circ} \mathrm{C}$ (dry ice-liquid nitrogen-ethyl acetate) was added $6.7 \mathrm{~mL}$ (16.7 mmol) of 2.5 M n-butyllithium in hexanes. The mixture was stirred for $15 \mathrm{~min}$ and 1.68 $\mathrm{mL}(16.7 \mathrm{mmol})$ of boron trifluoride etherate was added by syringe. The mixture was stirred for $15 \mathrm{~min}$ and a solution of $2.28 \mathrm{~g}(0.56 \mathrm{mmol})$ of oxetanes 14 and 7-epi-14 (1:1) in $3 \mathrm{~mL}$ of dry tetrahydrofuran was added by cannula (followed by two 2-mL tetrahydrofuran rinses). The solution was stirred for $3 \mathrm{~h}$ and the temperature was then slowly raised to rt over $30 \mathrm{~min}$ period. The mixture was then poured into $10 \mathrm{~mL}$ of saturated aqueous sodium bicarbonate. The aqueous phase was extracted with three $20-\mathrm{mL}$ portions of diethyl ether. The combined organic phases were washed with $50 \mathrm{~mL}$ of brine, dried $\left(\mathrm{Na}_{2} \mathrm{SO}_{4}\right)$, filtered, and concentrated in vacuo. The residue was purified by chromatography over $50 \mathrm{~g}$ of silica gel (hexanes-ethyl acetate, 5:1) to give a mixture of alkynes 15 and 7-epi-15 (1:1) which was chromatographed again using MPLC (hexanes-ethyl acetate, 8:1) to afford $760 \mathrm{mg}(42 \%)$ of alkyne 15 and 720 $\mathrm{mg} \mathrm{(39 \% )} \mathrm{of} \mathrm{alkyne} \mathrm{7-epi-15} \mathrm{as} \mathrm{colorless} \mathrm{oils.} \mathrm{Alkyne} \mathrm{15:} \mathrm{IR} \mathrm{(neat)} \mathrm{3436,} \mathrm{2235,} 1711 \mathrm{~cm}^{-1}$; ${ }^{1} \mathrm{H}$ NMR $\left(\mathrm{C}_{6} \mathrm{D}_{6}, 500 \mathrm{MHz}\right) \delta 0.88\left(\mathrm{t}, J=7.0 \mathrm{~Hz}, 3 \mathrm{H}, \mathrm{CH}_{2} \mathrm{CH}_{3}\right), 0.99\left(\mathrm{~m}, 1 \mathrm{H}, \mathrm{C}_{2} \mathrm{OH}\right), 1.29(\mathrm{~s}, 3 \mathrm{H}$, $\left.\mathrm{CH}_{3}\right), 1.53\left(\mathrm{~m}, 1 \mathrm{H}, \mathrm{CH}_{2} \mathrm{OH}\right), 1.54\left(\mathrm{~s}, 3 \mathrm{H}, \mathrm{CH}_{3}\right), 1.63(\mathrm{~s}, 1 \mathrm{H}, \mathrm{OH}), 1.96$ and $2.05\left(\mathrm{~m}, 2 \mathrm{H}, \mathrm{CH}_{2} \mathrm{C} \equiv\right)$, 1.97 and $2.25\left(\mathrm{ABq}, J=18.0 \mathrm{~Hz}, 2 \mathrm{H}, \mathrm{CH}_{2}\right), 3.46(\mathrm{~d}, J=11.0 \mathrm{~Hz}, 1 \mathrm{H}, \mathrm{C} \underline{\mathrm{HOH}}), 3.63$ and 3.85 (ABq, $J=6.5 \mathrm{~Hz}, 2 \mathrm{H}, \mathrm{CH}_{2} \mathrm{O}$ ), 3.90 (q, J = 7.0 Hz, 2H, $\mathrm{CH}_{2} \mathrm{CH}_{3}$ ), 4.14 (s, $1 \mathrm{H}, \mathrm{CHBr}$ ), 5.09 (s, $1 \mathrm{H}$, 
$=\mathrm{CH}) ;{ }^{13} \mathrm{C} \operatorname{NMR}\left(\mathrm{C}_{6} \mathrm{D}_{6}, 125 \mathrm{MHz}\right) \delta 13.7(\mathrm{q}), 15.7(\mathrm{t}), 21.9(\mathrm{q}), 23.1(\mathrm{q}), 29.9(\mathrm{t}), 44.0(\mathrm{t}), 52.3$

(s), $56.4(\mathrm{~d}), 61.4(\mathrm{t}), 69.1(\mathrm{~d}), 73.6(\mathrm{t}), 74.5(\mathrm{~s}), 80.5(\mathrm{~s}), 87.9(\mathrm{~s}), 122.8(\mathrm{~d}), 135.6(\mathrm{~s}), 153.5(\mathrm{~s})$; exact mass calcd. for $\mathrm{C}_{17} \mathrm{H}_{23}{ }^{79} \mathrm{BrO}_{4}(\mathrm{M}+\mathrm{Na})^{+} \mathrm{m} / \mathrm{z}$ 393.0677, found $\mathrm{m} / \mathrm{z}$ 393.0672. Alkyne 7-epi-15: IR (neat) 3448, 2236, $1710 \mathrm{~cm}^{-1} ;{ }^{1} \mathrm{H}$ NMR $\left(\mathrm{C}_{6} \mathrm{D}_{6}, 500 \mathrm{MHz}\right) \delta 0.88(\mathrm{t}, J=7.0 \mathrm{~Hz}, 3 \mathrm{H}$, $\left.\mathrm{CH}_{2} \mathrm{CH}_{3}\right), 1.12\left(\mathrm{~m}, 1 \mathrm{H}, \mathrm{C}_{2} \mathrm{OH}\right), 1.22\left(\mathrm{~s}, 3 \mathrm{H}, \mathrm{CH}_{3}\right), 1.43\left(\mathrm{~m}, 1 \mathrm{H}, \mathrm{CH}_{2} \mathrm{OH}\right), 1.52\left(\mathrm{~s}, 3 \mathrm{H}, \mathrm{CH}_{3}\right)$, $2.12\left(\mathrm{dd}, J=8.0,6.0 \mathrm{~Hz}, 2 \mathrm{H}, \mathrm{CH}_{2} \mathrm{C} \equiv\right), 1.91$ and $2.10\left(\mathrm{ABq}, J=18.0 \mathrm{~Hz}, 2 \mathrm{H}, \mathrm{CH}_{2}\right), 3.44(\mathrm{~d}, J=$ $11.5 \mathrm{~Hz}, 1 \mathrm{H}, \mathrm{C} \underline{\mathrm{HOH}}), 3.40$ and $3.60\left(\mathrm{ABq}, J=7.0 \mathrm{~Hz}, 2 \mathrm{H}, \mathrm{CH}_{2} \mathrm{O}\right), 3.52(\mathrm{~s}, 1 \mathrm{H}, \mathrm{CHBr}), 3.92(\mathrm{q}$, $\left.J=7.0 \mathrm{~Hz}, 2 \mathrm{H}, \mathrm{CH}_{2} \mathrm{CH}_{3}\right), 5.41(\mathrm{~s}, 1 \mathrm{H},=\mathrm{CH}) ;{ }^{13} \mathrm{C} \mathrm{NMR}\left(\mathrm{C}_{6} \mathrm{D}_{6}, 125 \mathrm{MHz}\right) \delta 13.7(\mathrm{q}), 15.2(\mathrm{t})$, $21.9(\mathrm{q}), 22.8(\mathrm{q}), 29.8(\mathrm{t}), 43.7(\mathrm{t}), 51.5(\mathrm{~s}), 57.5(\mathrm{~d}), 61.4(\mathrm{t}), 71.7(\mathrm{~d}), 74.4(\mathrm{t}), 75.5(\mathrm{~s}), 81.3$ (s), 88.2 (s), 122.7 (d), 135.0 (s), 153.6 (s); exact mass calcd. for $\mathrm{C}_{17} \mathrm{H}_{23}{ }^{79} \mathrm{BrO}_{4}(\mathrm{M}+\mathrm{Na})^{+} \mathrm{m} / \mathrm{z}$ 393.0677, found $m / z 393.0678$. 


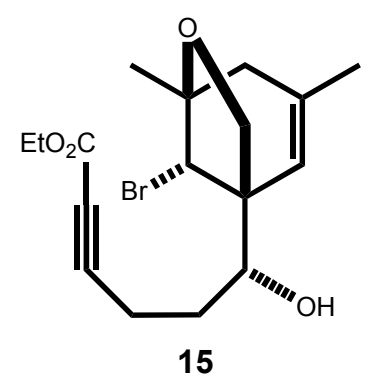

(500 MHz, $\mathrm{C}_{6} \mathrm{D}_{6}$ )

DY-2-42A

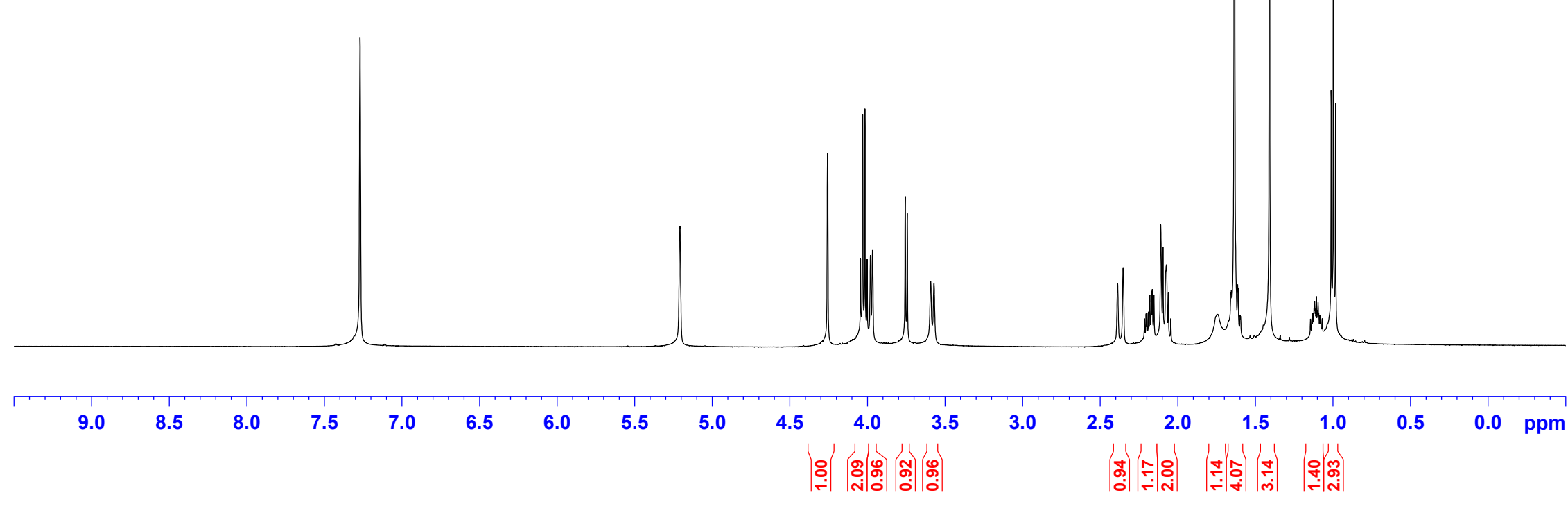




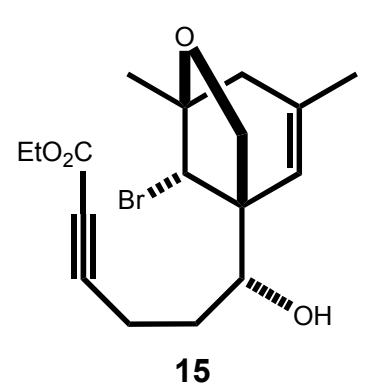

(500 MHz, $\mathrm{C}_{6} \mathrm{D}_{6}$ )

DY-2-42A

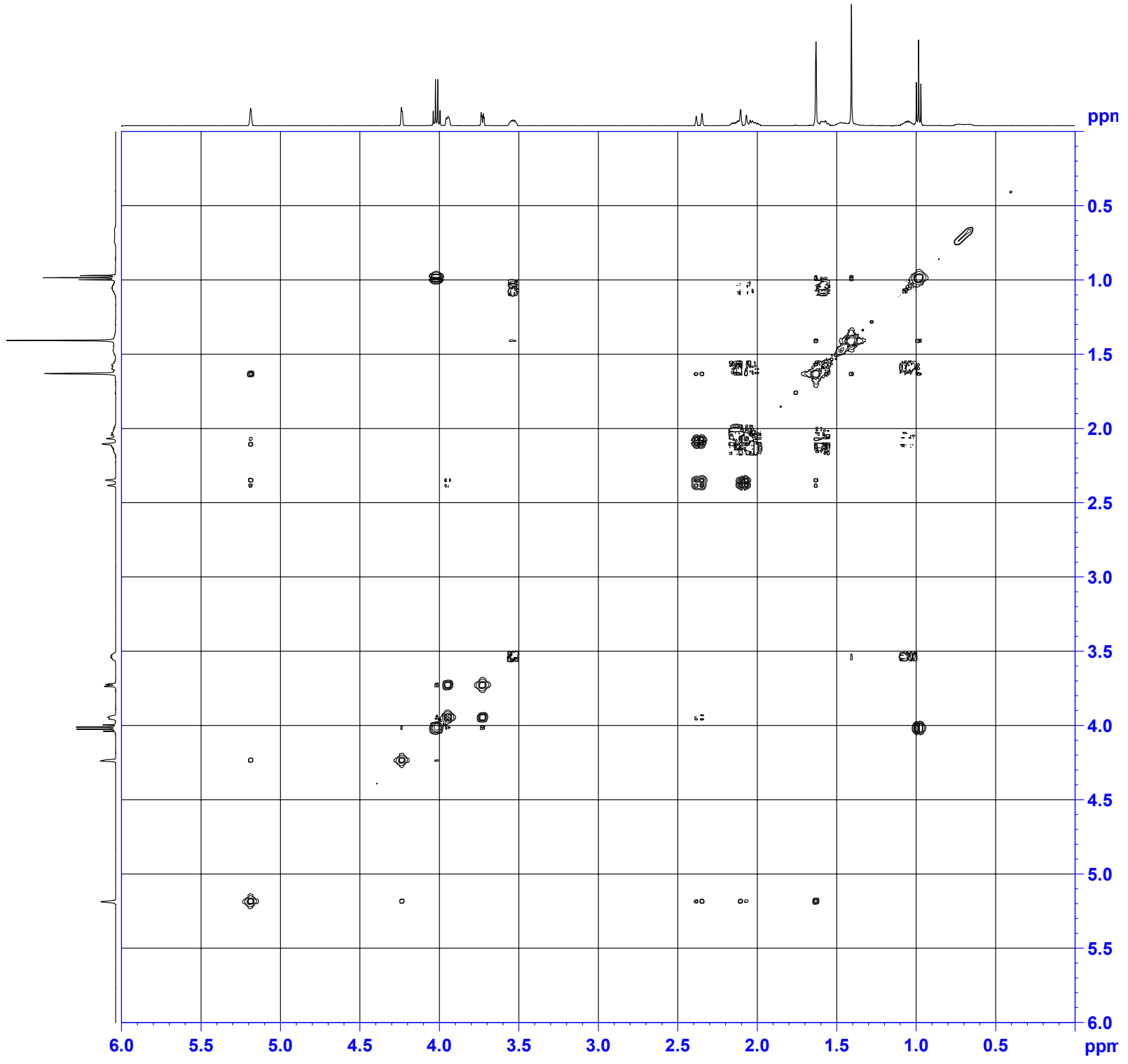

32 


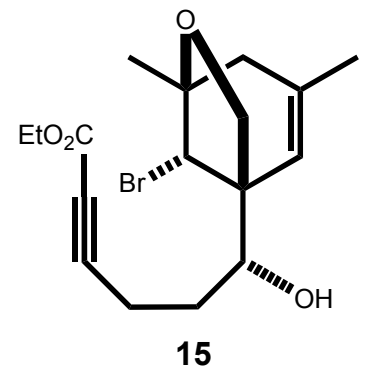

(125 MHz, $\mathrm{C}_{6} \mathrm{D}_{6}$ )

DY-2-42A 


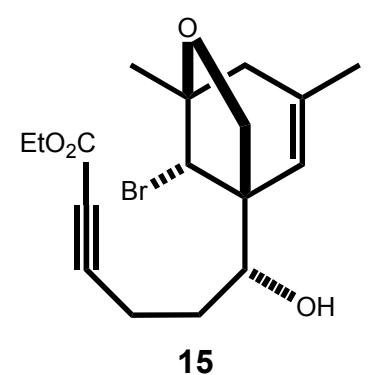

(125 MHz, $\mathrm{C}_{6} \mathrm{D}_{6}$ )

DY-2-42A

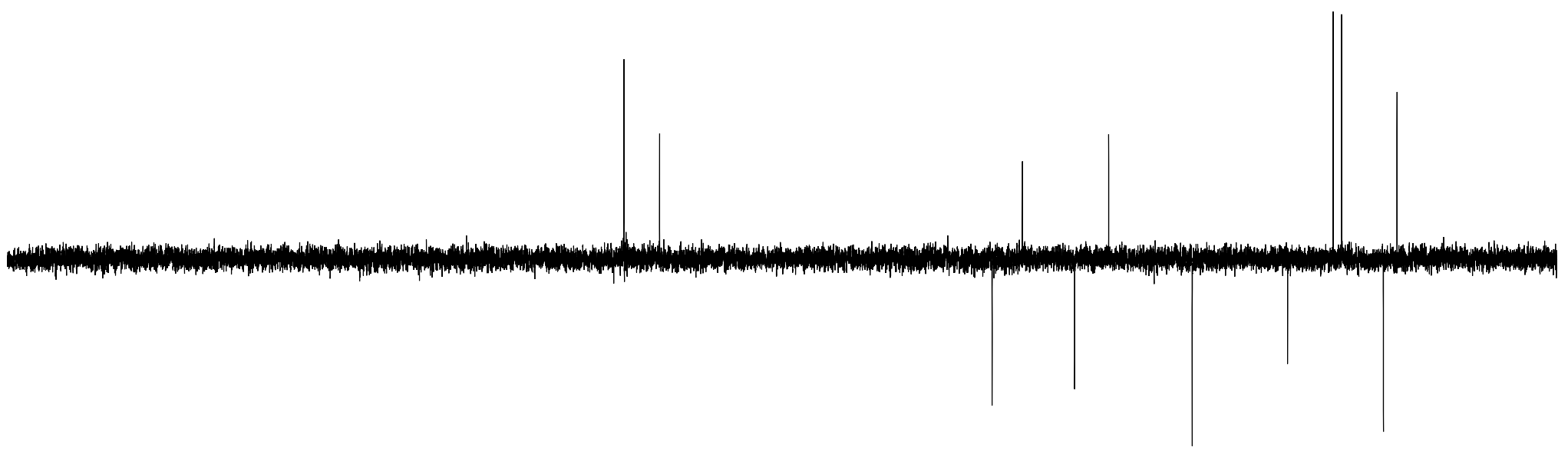




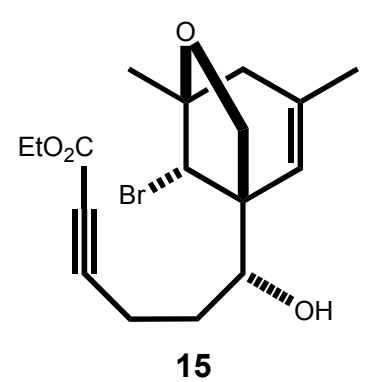

$\left({ }^{13} \mathrm{C} 125 \mathrm{MHz}\right.$,

${ }^{1} \mathrm{H} 500 \mathrm{MHz}, \mathrm{C}_{6} \mathrm{D}_{6}$ )

DY-2-42A

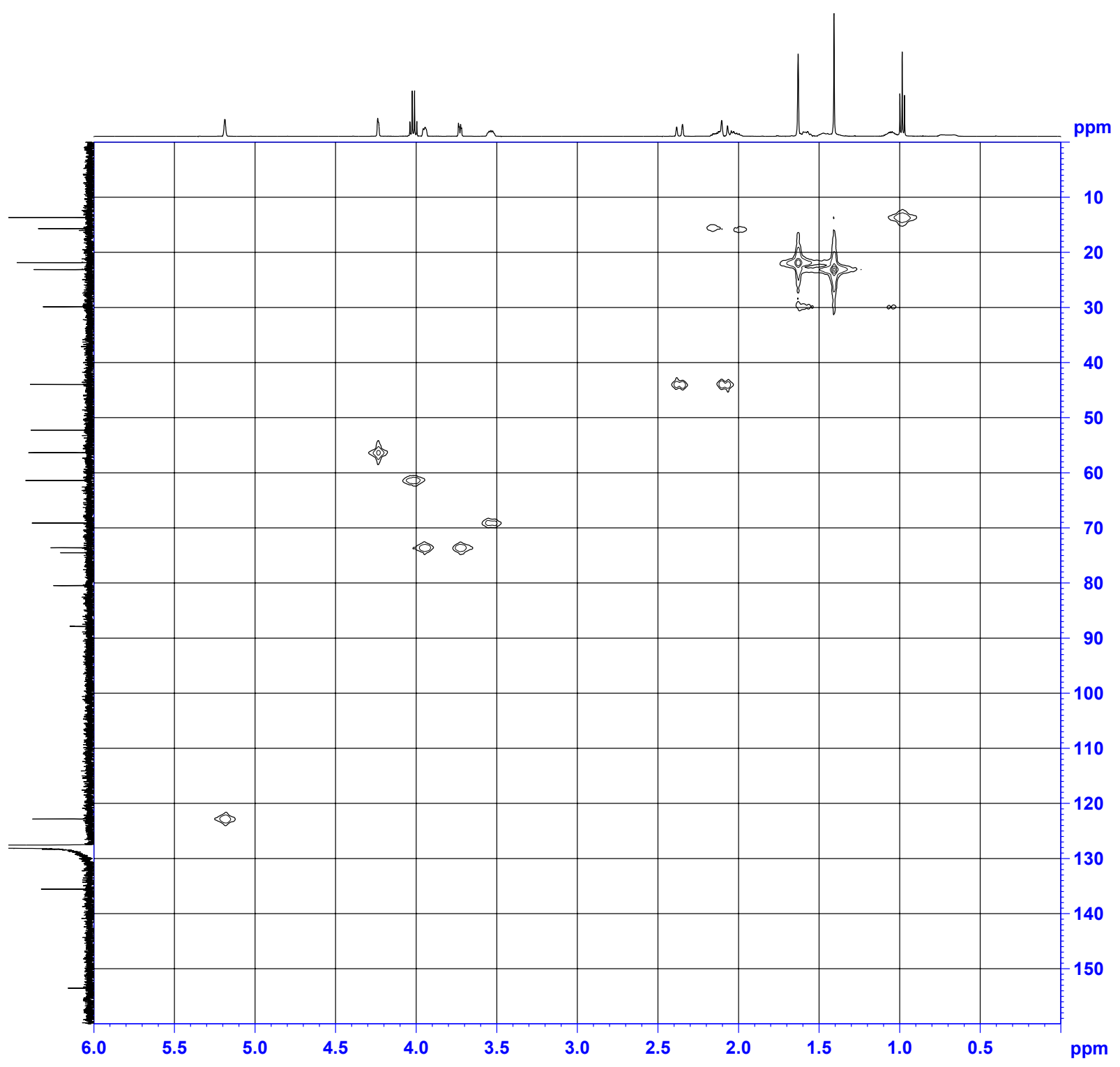

35 


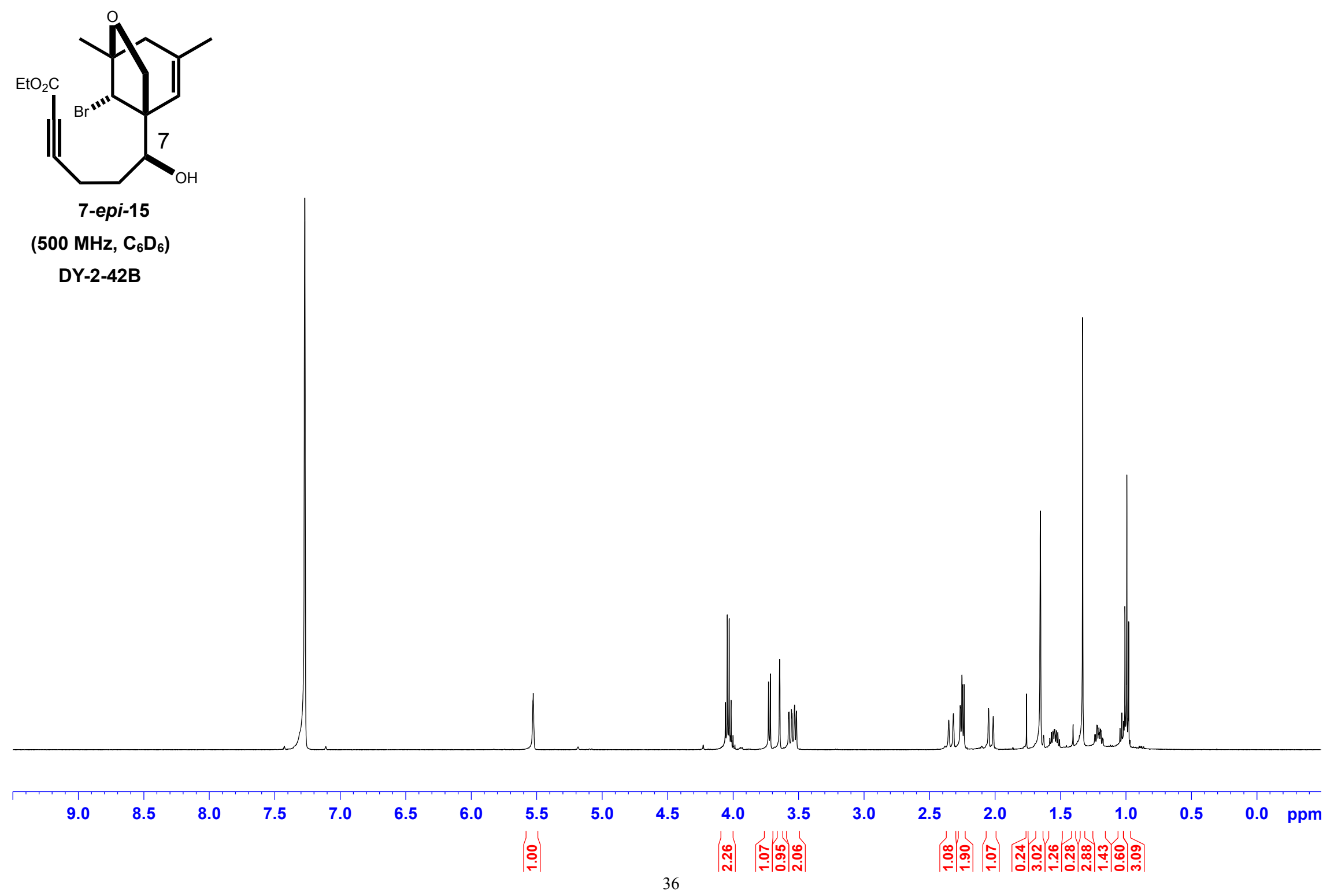




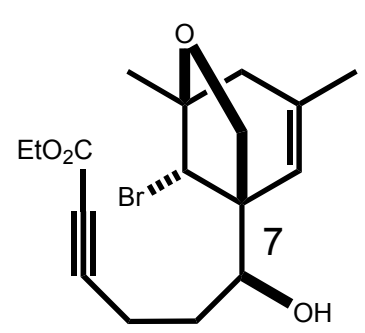

7-epi-15

( $500 \mathrm{MHz}, \mathrm{C}_{6} \mathrm{D}_{6}$ )

DY-2-42B

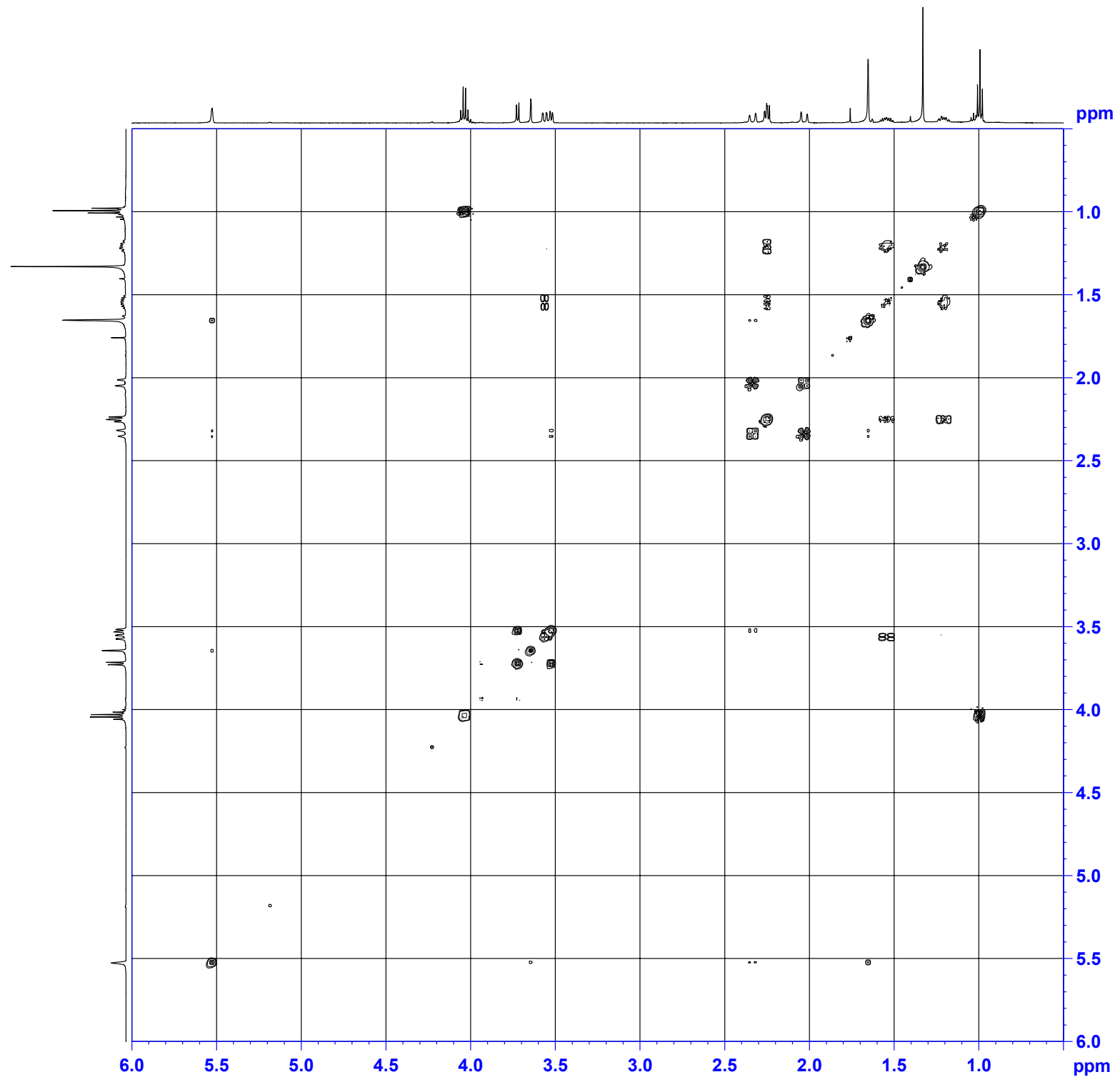




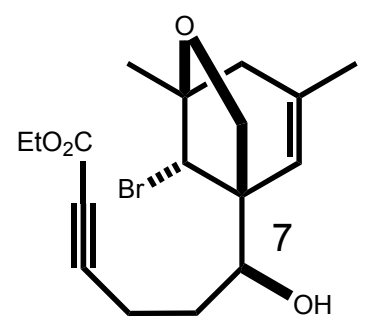

7-epi-15

(125 MHz, $\mathrm{C}_{6} \mathrm{D}_{6}$ )

DY-2-42B

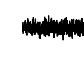

$\begin{array}{lllllllllllll}210 & 200 & 190 & 180 & 170 & 160 & 150 & 140 & 130 & 120 & 110 & 100 & 90\end{array}$

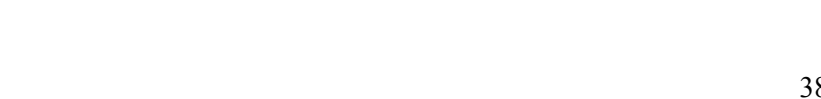




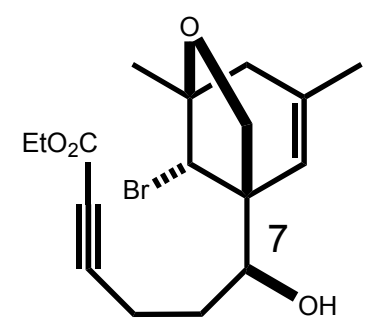

7-epi-15

(125 MHz, $\mathrm{C}_{6} \mathrm{D}_{6}$ )

DY-2-42B 


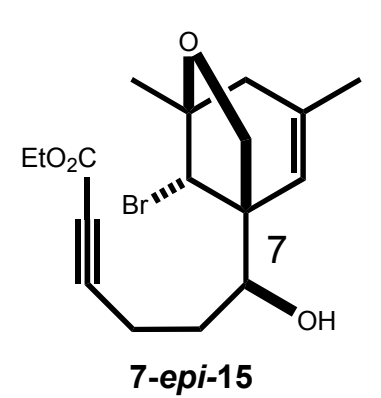

$\left({ }^{13} \mathrm{C} 125 \mathrm{MHz}\right.$,

${ }^{1} \mathrm{H} 500 \mathrm{MHz}, \mathrm{C}_{6} \mathrm{D}_{6}$ )

DY-2-42B

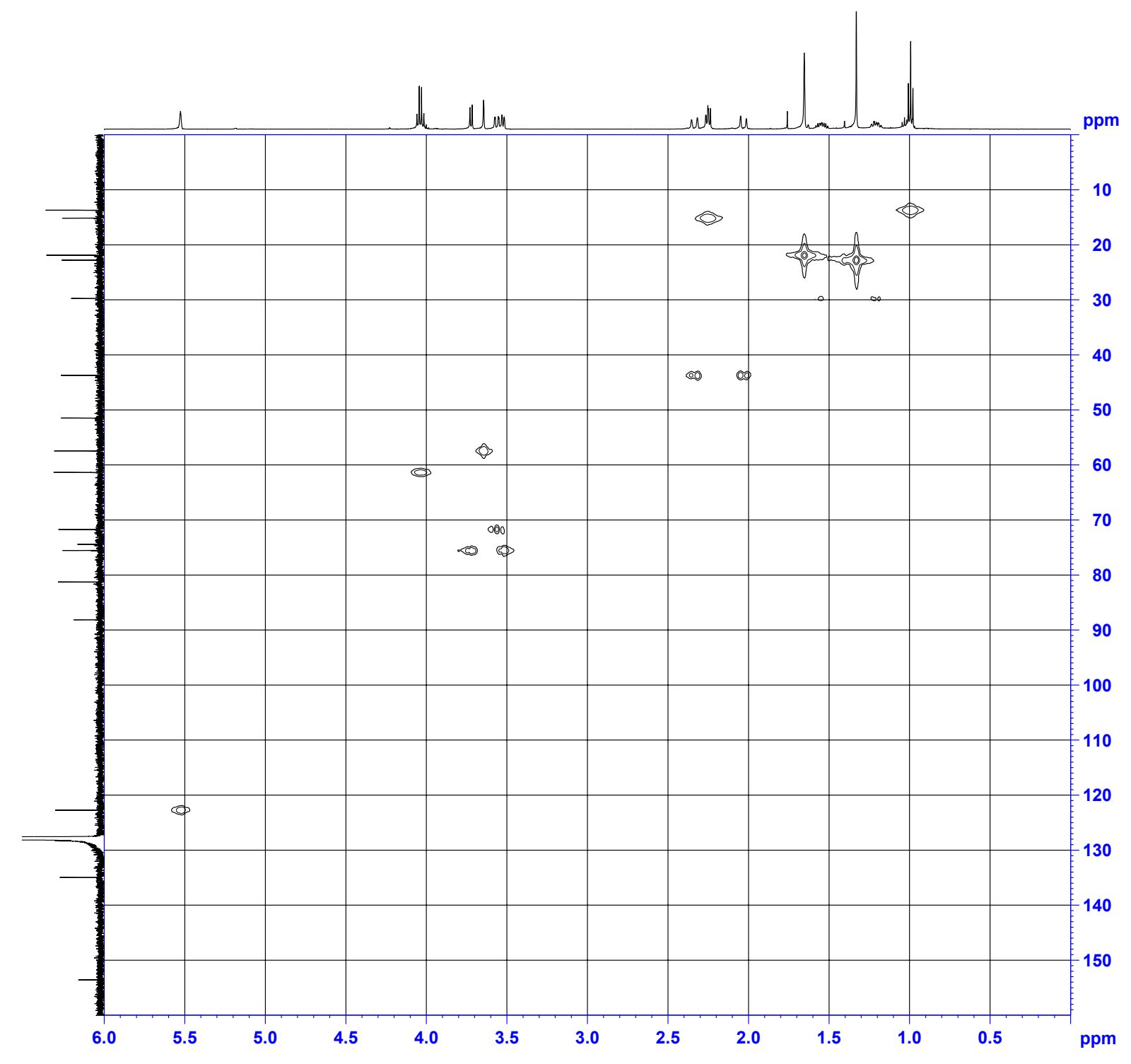

40 


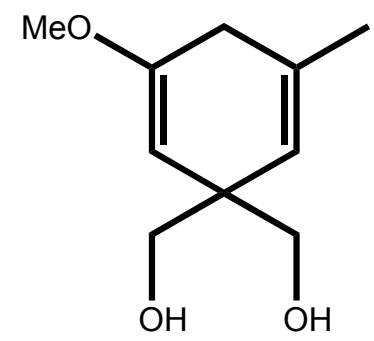

18

Diol 18. To a solution of $21.7 \mathrm{~g}(120 \mathrm{mmol})$ of 16 and $9.03 \mathrm{~g}(120 \mathrm{mmol})$ of tert-butanol in 200 $\mathrm{mL}$ of dry $\mathrm{THF}$ at $-78^{\circ} \mathrm{C}$ under $\mathrm{N}_{2}$ was added $300 \mathrm{~mL}$ of liquid ammonia. To the mixture was added $1.83 \mathrm{~g}(264 \mathrm{mmol})$ of lithium in small pieces over a period of $30 \mathrm{~min}$. The resulting dark blue solution was stirred for $30 \mathrm{~min}$ and the excess lithium was then destroyed by addition of $0.1 \mathrm{~mL}$ of 1,3-pentadiene. To the resulting pale yellow solution was added a solution of $29.4 \mathrm{~g}$ (121 mmol) of iodomethyl pivalate in $100 \mathrm{~mL}$ of dry THF via addition funnel. The mixture was stirred for $2 \mathrm{~h}$ and the reaction was then quenched by addition of $14 \mathrm{~g}(0.264 \mathrm{~mol})$ of solid $\mathrm{NH}_{4} \mathrm{Cl}$. The ammonia was allowed to evaporate overnight under $\mathrm{N}_{2}$. The mixture was filtered and concentrated in vacuo to give $35.6 \mathrm{~g}$ of pale yellow oil which shown one spot by TLC (silica gel, hexanes-ethyl acetate, $2: 1$ ). The pale yellow oil was used directly in the next reaction without further purification. To a slurry of $9.10 \mathrm{~g}(240 \mathrm{mmol})$ of lithium aluminum hydride in $200 \mathrm{~mL}$ of diethyl ether cooled to $-78{ }^{\circ} \mathrm{C}$ (dry ice-acetone bath) was added a solution of $35.6 \mathrm{~g}(120 \mathrm{mmol})$ of ester $17 \mathrm{in} 100 \mathrm{~mL}$ of diethyl ether over $1 \mathrm{~h}$. The mixture was allowed to stir at $-78^{\circ} \mathrm{C}$ for $5 \mathrm{~h}$ and then the temperature was raised to $\mathrm{rt}$ and the mixture was stirred over night. The mixture was cooled in an ice-water bath. To the stirred mixture was added $9.0 \mathrm{~mL}$ of water, $9.0 \mathrm{~mL}$ of $15 \%$ aqueous sodium hydroxide, and $18.0 \mathrm{~mL}$ of water sequentially over $2 \mathrm{~h}$, and the mixture was was stirred for $6 \mathrm{~h}$. The mixture was filtered and the filter cake was rinsed with two $100-\mathrm{mL}$ portions of diethyl ether. The filtrate was dried $\left(\mathrm{Na}_{2} \mathrm{SO}_{4}\right)$, filtered, and concentrated in vacuo to give a mixture of white needles and yellow oil from which $11.0 \mathrm{~g}(50 \%)$ of diol 18 was separated via filtration as white needles: $\mathrm{mp}$ 129-130 ${ }^{\circ} \mathrm{C} ;{ }^{1} \mathrm{H}$ NMR $\left(\mathrm{CD}_{2} \mathrm{Cl}_{2}, 500 \mathrm{MHz}\right) \delta 1.79$ (br s, 2H, OH), 1.80 (s, 3H, $\left.\mathrm{CH}_{3}\right), 2.68\left(\mathrm{~s}, 2 \mathrm{H}, \mathrm{CH}_{2}\right)$, $3.49\left(\mathrm{~d}, \mathrm{~J}=5.0 \mathrm{~Hz}, 4 \mathrm{H}, \mathrm{CH}_{2} \mathrm{OH}\right), 3.62\left(\mathrm{~s}, 3 \mathrm{H}, \mathrm{OCH}_{3}\right), 4.48(\mathrm{~s}, 1 \mathrm{H}, \mathrm{OC}=\mathrm{CH}), 5.30(\mathrm{~s}, 1 \mathrm{H},=\mathrm{CH})$; ${ }^{13} \mathrm{C}$ NMR $\left(\mathrm{CD}_{2} \mathrm{Cl}_{2}, 125 \mathrm{MHz}\right) \delta 22.5(\mathrm{q}), 34.0(\mathrm{t}), 47.5(\mathrm{~s}), 54.0(\mathrm{q}), 68.7(\mathrm{t}), 92.9(\mathrm{~d}), 122.0(\mathrm{~d})$, 134.4 (s), 156.8 (s); exact mass calcd. for $\mathrm{C}_{10} \mathrm{H}_{16} \mathrm{O}_{3}(\mathrm{M}+\mathrm{Na})^{+} \mathrm{m} / \mathrm{z}$ 207.0997, found $\mathrm{m} / \mathrm{z}$ 207.0991. Anal. calcd. for $\mathrm{C}_{10} \mathrm{H}_{16} \mathrm{O}_{3}$ : C, 65.19; $\mathrm{H}, 8.75$. Found: $\mathrm{C}, 65.33 ; \mathrm{H}, 8.83$. 


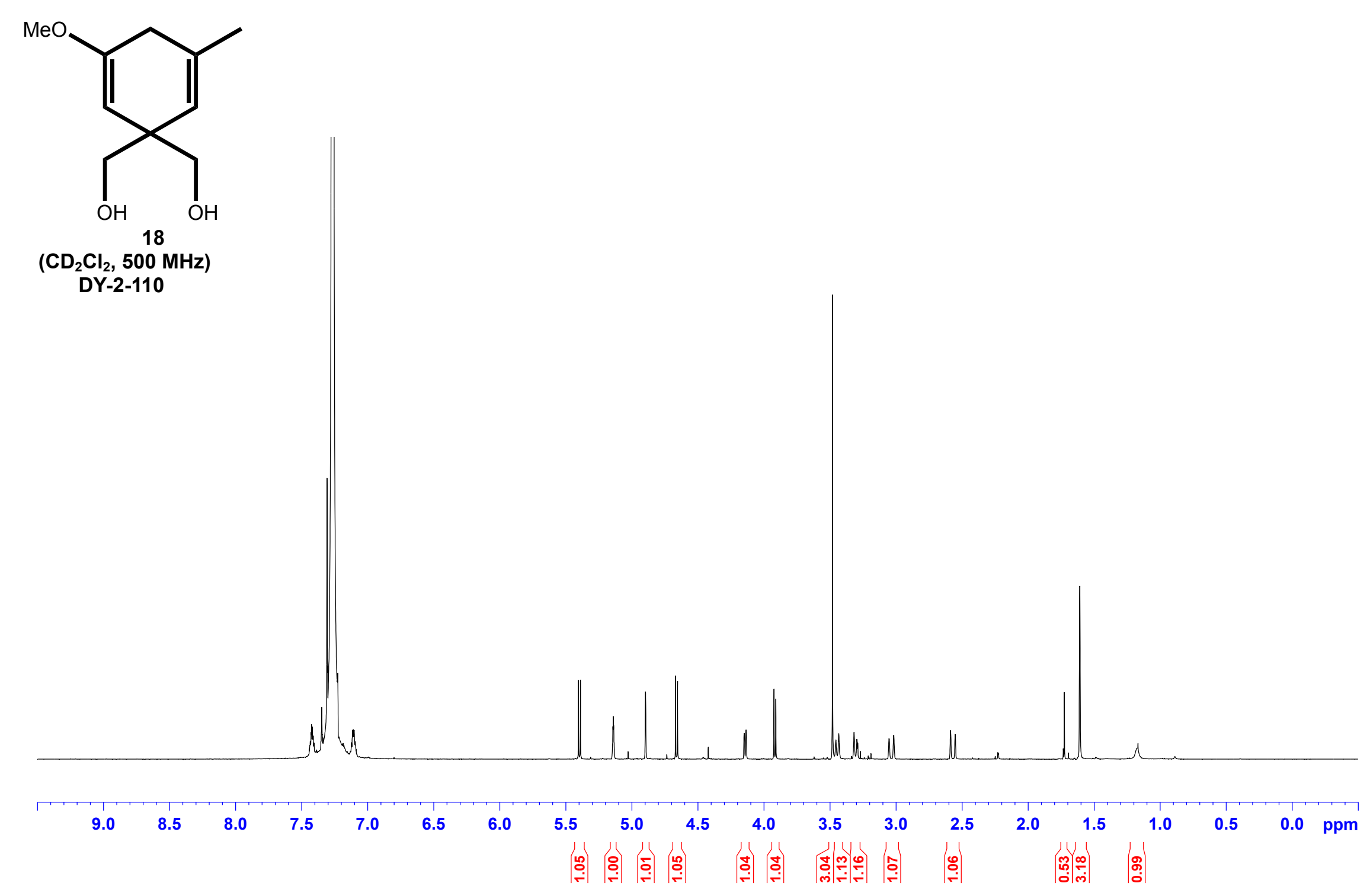




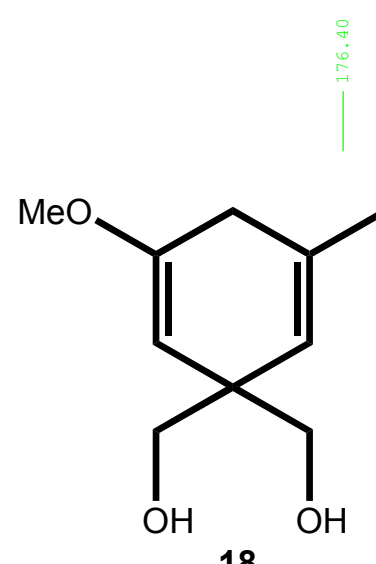

18

$\left(\mathrm{CD}_{2} \mathrm{Cl}_{2}, 125 \mathrm{MHz}\right)$

DY-2-110

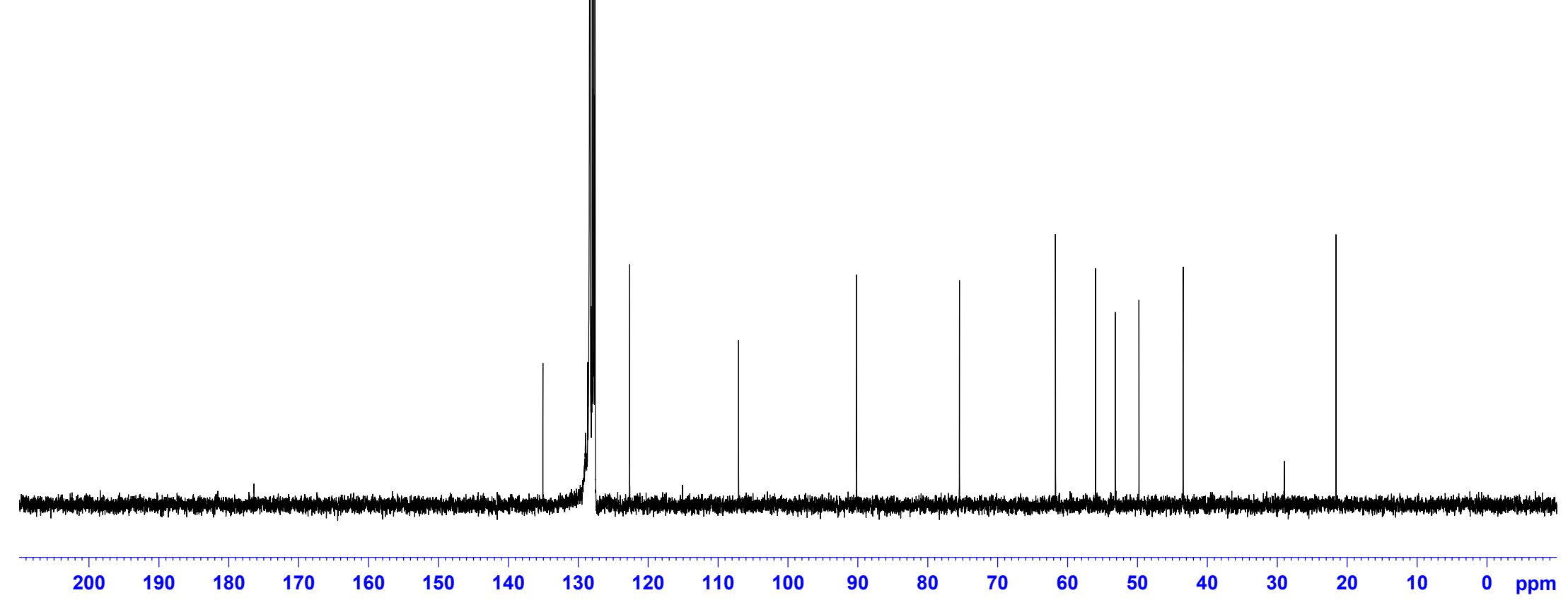




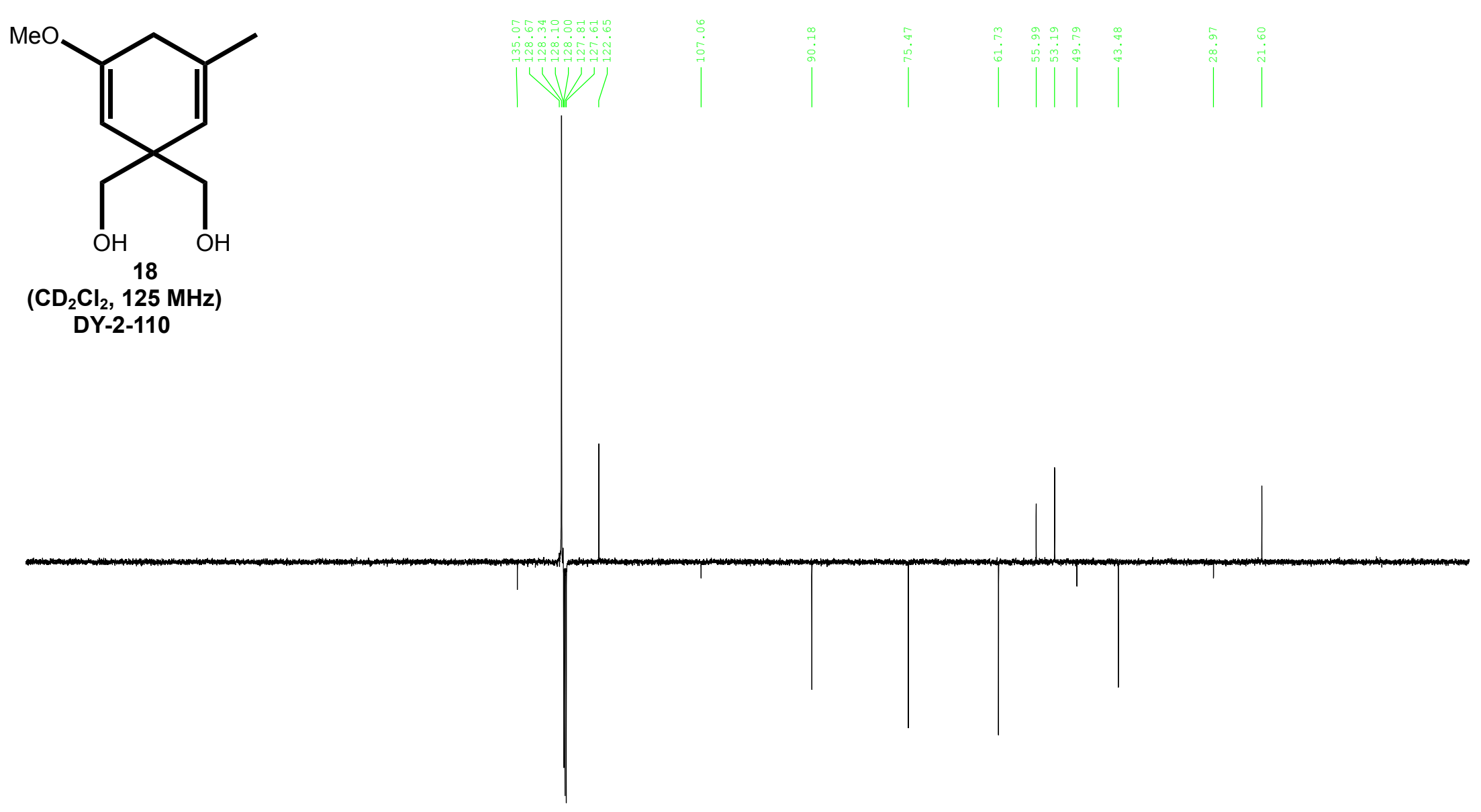

$\begin{array}{llllllllllllllllllllllll}200 & 190 & 180 & 170 & 160 & 150 & 140 & 130 & 120 & 110 & 100 & 90 & 80 & 70 & 60 & 50 & 40 & 30 & 20 & 10 & 0 & \mathrm{ppm}\end{array}$ 


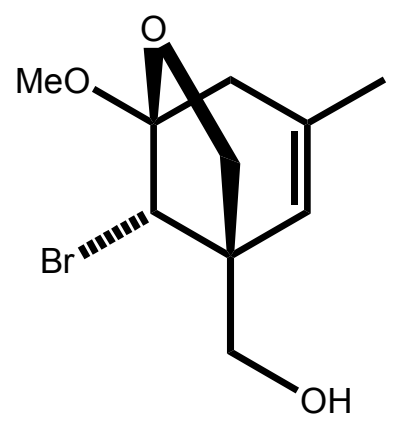

19

Alcohol 19. To a solution of $2.00 \mathrm{~g}(10.8 \mathrm{mmol})$ of diol 18 in $20 \mathrm{~mL}$ of dry dichloromethane at 0 ${ }^{\circ} \mathrm{C}$ (dry ice-acetone) was added $2.10 \mathrm{~g}(15.0 \mathrm{mmol})$ of powdered potassium carbonate, followed by slow addition of $2.02 \mathrm{~g}(11.0 \mathrm{mmol})$ of $\mathrm{N}$-bromosuccinimide over $5 \mathrm{~min}$. The solution was stirred for $5 \mathrm{~min}$, then poured into $20 \mathrm{~mL}$ of water. The aqueous phase was extracted with two $20-\mathrm{mL}$ portions of dichloromethane. The combined organic phases were dried $\left(\mathrm{Na}_{2} \mathrm{SO}_{4}\right)$, filtered, and concentrated in vacuo to afford a solution of the alcohol 19 in $10 \mathrm{~mL}$ of dichloromethane which was used directly in the next step. Due to instability of pure alcohol 19 in air, only NMR spectral data were collected: ${ }^{1} \mathrm{H}$ NMR $\left(\mathrm{C}_{6} \mathrm{D}_{6}, 500 \mathrm{MHz}\right) \delta 1.49\left(\mathrm{~s}, 3 \mathrm{H}, \mathrm{CH}_{3}\right), 2.42,2.81(\mathrm{ABq}, J=17.5 \mathrm{~Hz}, 2 \mathrm{H}$, $\left.\mathrm{CH}_{2} \mathrm{C}=\right)$, 3.19, $3.37\left(\mathrm{ABq}, J=11.0 \mathrm{~Hz}, 2 \mathrm{H}, \mathrm{CH}_{2} \mathrm{OH}\right), 3.24\left(\mathrm{~s}, 3 \mathrm{H}, \mathrm{OCH}_{3}\right), 3.79,4.00(\mathrm{ABq}, J=6.5$ $\left.\mathrm{Hz}, 2 \mathrm{H}, \mathrm{CH}_{2} \mathrm{O}\right), 4.51(\mathrm{~s}, 1 \mathrm{H}, \mathrm{CHBr}), 4.98(\mathrm{~s}, 1 \mathrm{H},=\mathrm{CH})$, the $\mathrm{OH}$ was not detected; ${ }^{13} \mathrm{C}$ NMR $\left(\mathrm{C}_{6} \mathrm{D}_{6}\right.$, $125 \mathrm{MHz}) \delta 21.5(\mathrm{q}), 43.1(\mathrm{t}), 48.8(\mathrm{q}), 49.3(\mathrm{~d}), 49.9(\mathrm{~s}), 61.6(\mathrm{t}), 75.0(\mathrm{t}), 107.3(\mathrm{~s}), 122.4(\mathrm{~d})$, $135.6(\mathrm{~s})$. 


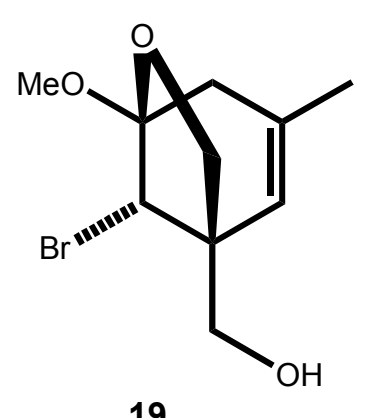

$\left(C_{6} D_{6}, 500 \mathrm{MHz}\right)$

(DY-2-100)
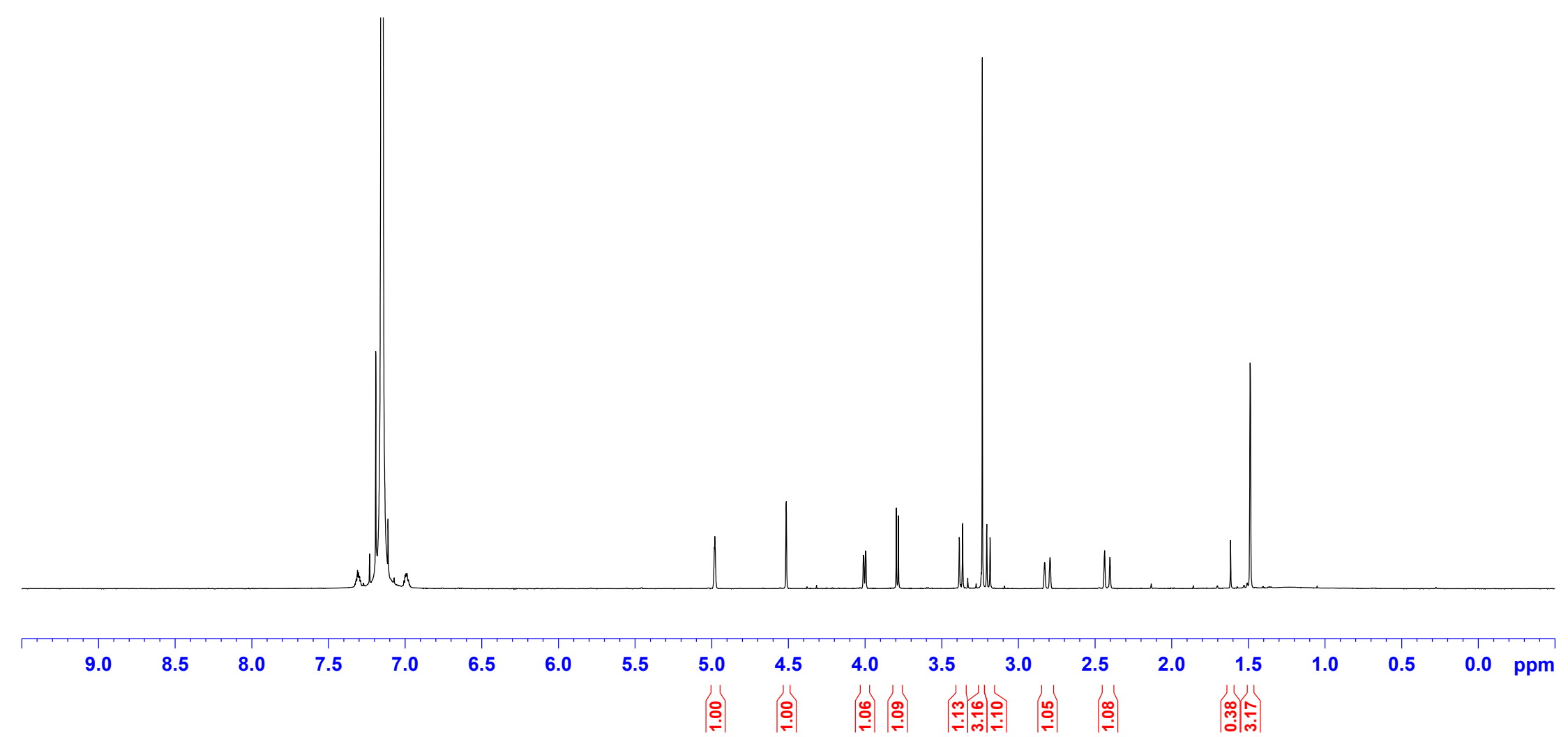


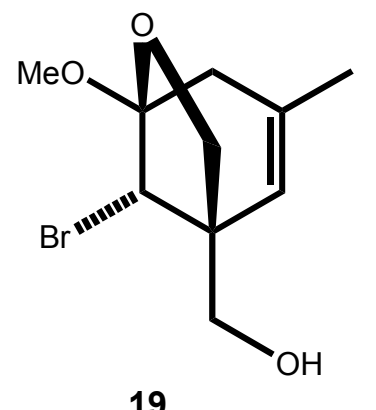

19

$\left(\mathrm{C}_{6} \mathrm{D}_{6}, 125 \mathrm{MHz}\right)$

(DY-2-100) 


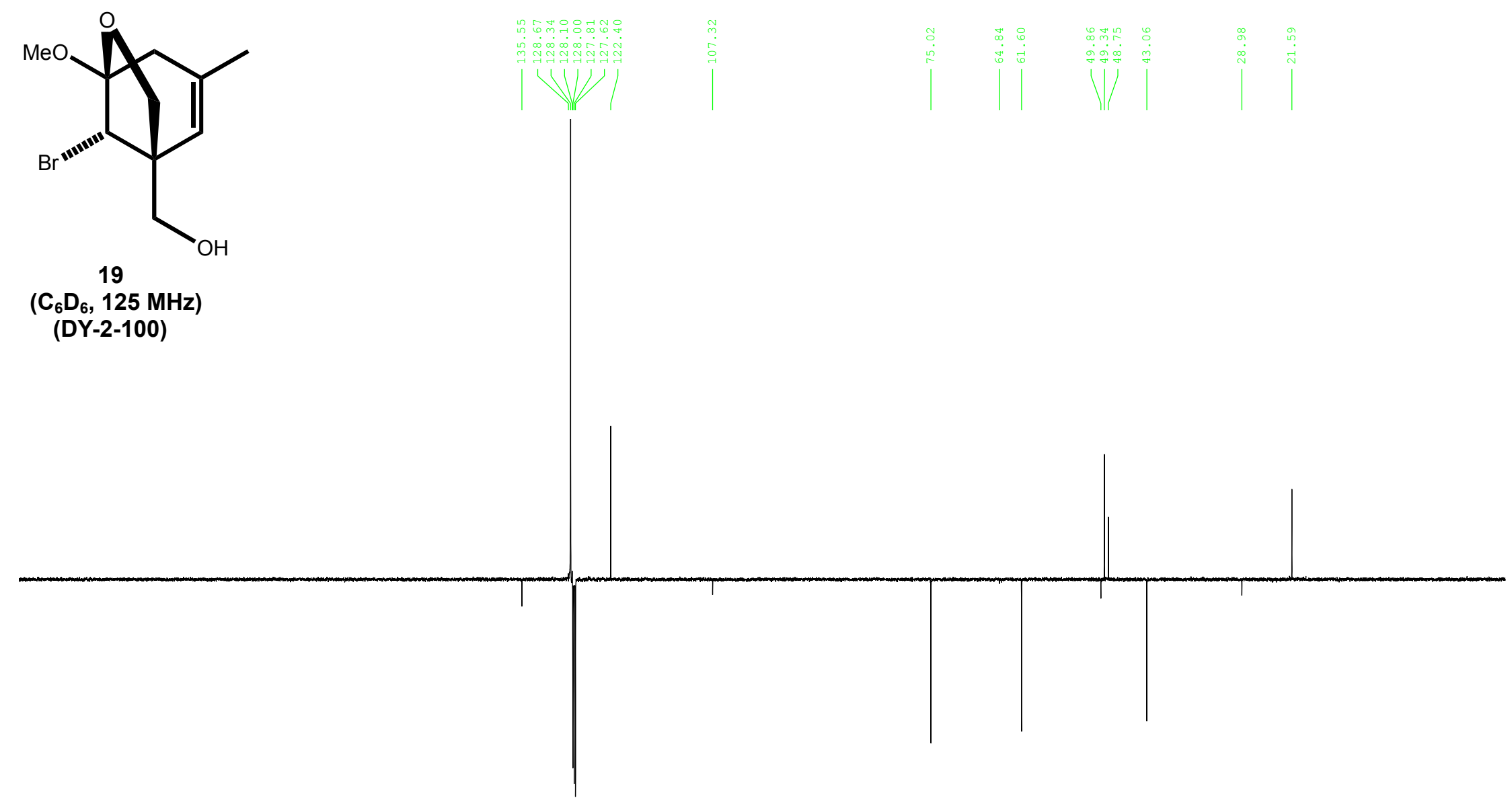




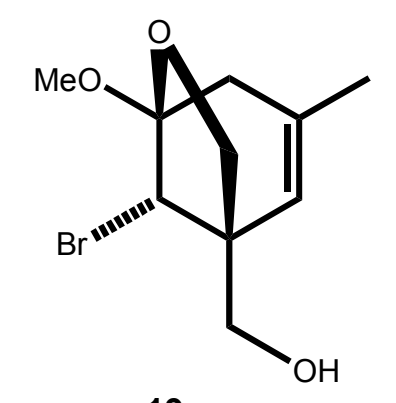

19

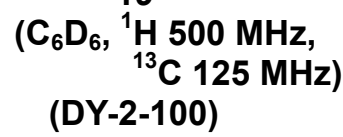

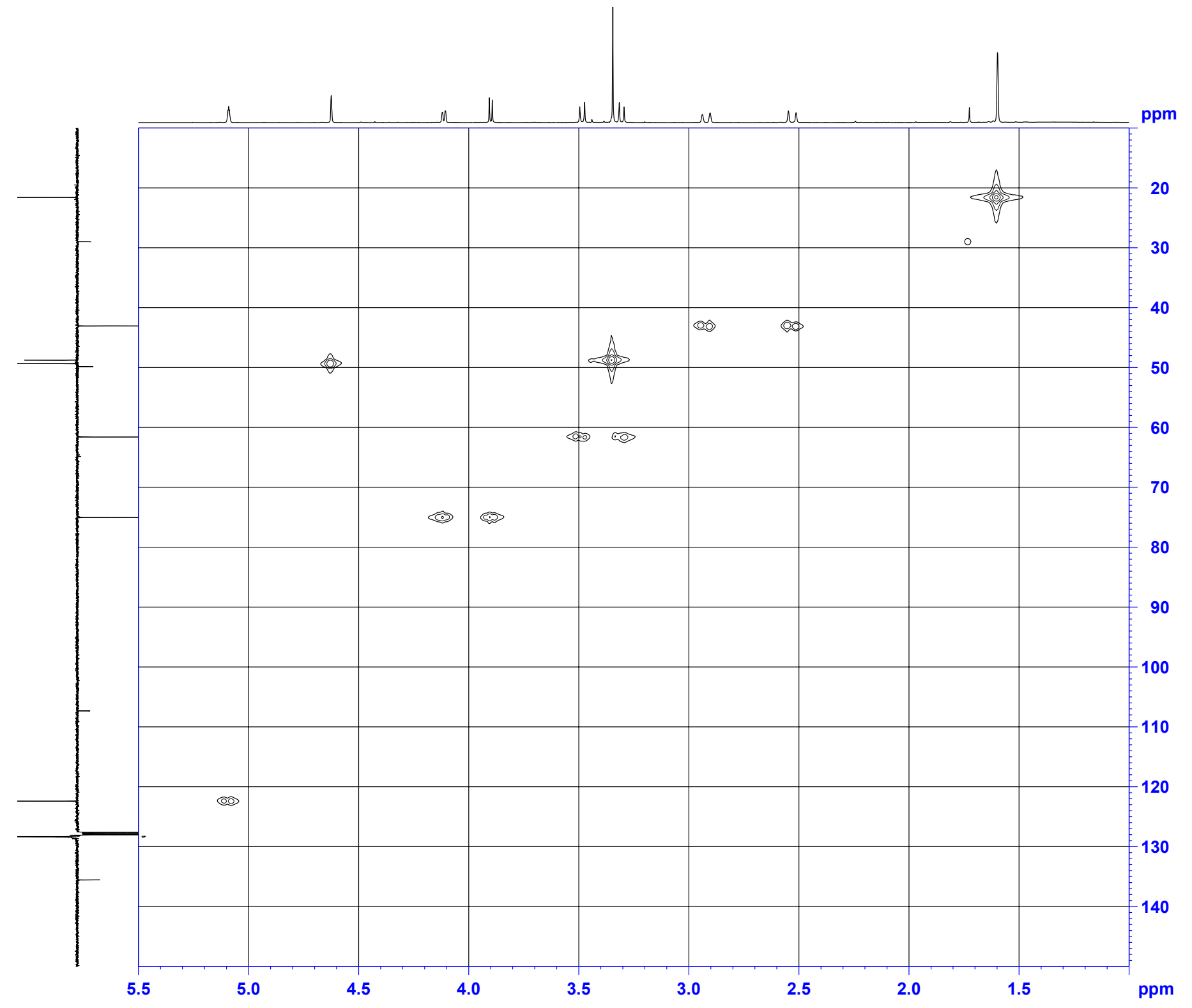

49 


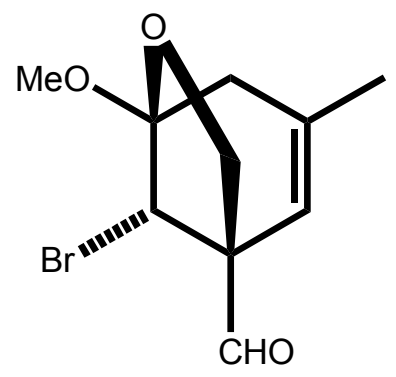

20

Aldehyde 20. To a solution of $1.63 \mathrm{~mL}(19.1 \mathrm{mmol})$ of oxalyl chloride in $100 \mathrm{~mL}$ of dry dichloromethane at $-78{ }^{\circ} \mathrm{C}$ (dry ice-acetone) was added a solution of $2.73 \mathrm{~mL}(38.4 \mathrm{mmol})$ of dry dimethylsulfoxide by syringe over $2 \mathrm{~min}$. The solution was stirred cold for $15 \mathrm{~min}$, and a solution of $3.16 \mathrm{~g}$ (12.0 mmol) of alcohol 19 in $20 \mathrm{~mL}$ of dry dichloromethane was added by cannula over $30 \mathrm{~min}$. The solution was stirred cold for $1 \mathrm{~h}$, and $10.0 \mathrm{~mL}(60 \mathrm{mmol})$ of diisoproplyethylamine was added rapidly via syringe. The mixture was stirred cold for $30 \mathrm{~min}$, and then raised to rt. The mixture was poured into $80 \mathrm{~mL}$ of dichloromethane in an ice-bath, and then washed with three $100-\mathrm{mL}$ portions of $3 \%$ aqueous $\mathrm{NH}_{4} \mathrm{Cl}$ and $100 \mathrm{~mL}$ of saturated aqueous $\mathrm{NaHCO}_{3}$. The organic phase was dried $\left(\mathrm{Na}_{2} \mathrm{SO}_{4}\right)$, filtered, and concentrated in vacuo to afford $3.13 \mathrm{~g}(99 \%)$ of aldehyde 20 as a brown oil that was sufficiently pure for future reactions: ${ }^{1} \mathrm{H} \mathrm{NMR}\left(\mathrm{CDCl}_{3}, 500 \mathrm{MHz}\right) \delta 1.43$ $\left(\mathrm{s}, 3 \mathrm{H}, \mathrm{CH}_{3}\right), 2.29,2.65\left(\mathrm{ABq}, J=17.5 \mathrm{~Hz}, 2 \mathrm{H}, \mathrm{CH}_{2}\right), 3.13\left(\mathrm{~s}, 3 \mathrm{H}, \mathrm{OCH}_{3}\right), 3.53,3.68(\mathrm{ABq}, J=6.5$ $\mathrm{Hz}, 2 \mathrm{H}, \mathrm{CH}_{2} \mathrm{O}$ ), 4.41 (s, $\left.1 \mathrm{H}, \mathrm{CHBr}\right), 5.66(\mathrm{~s}, 1 \mathrm{H},=\mathrm{CH}), 9.07$ (s, $\left.1 \mathrm{H}, \mathrm{CHO}\right) ;{ }^{13} \mathrm{C} \mathrm{NMR}\left(\mathrm{CDCl}_{3}, 125\right.$ $\mathrm{MHz}) \delta 21.5(\mathrm{q}), 42.8(\mathrm{t}), 47.0(\mathrm{~d}), 49.0(\mathrm{q}), 59.5(\mathrm{~s}), 73.7(\mathrm{t}), 107.6(\mathrm{~s}), 118.4(\mathrm{~d}), 136.8(\mathrm{~s}), 196.9$ (d). 


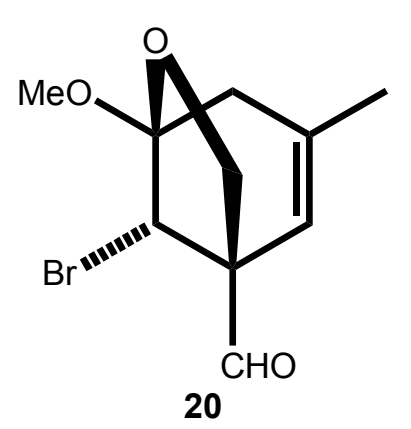

(CDCl $3,500 \mathrm{MHz}$ )

DY-2-102

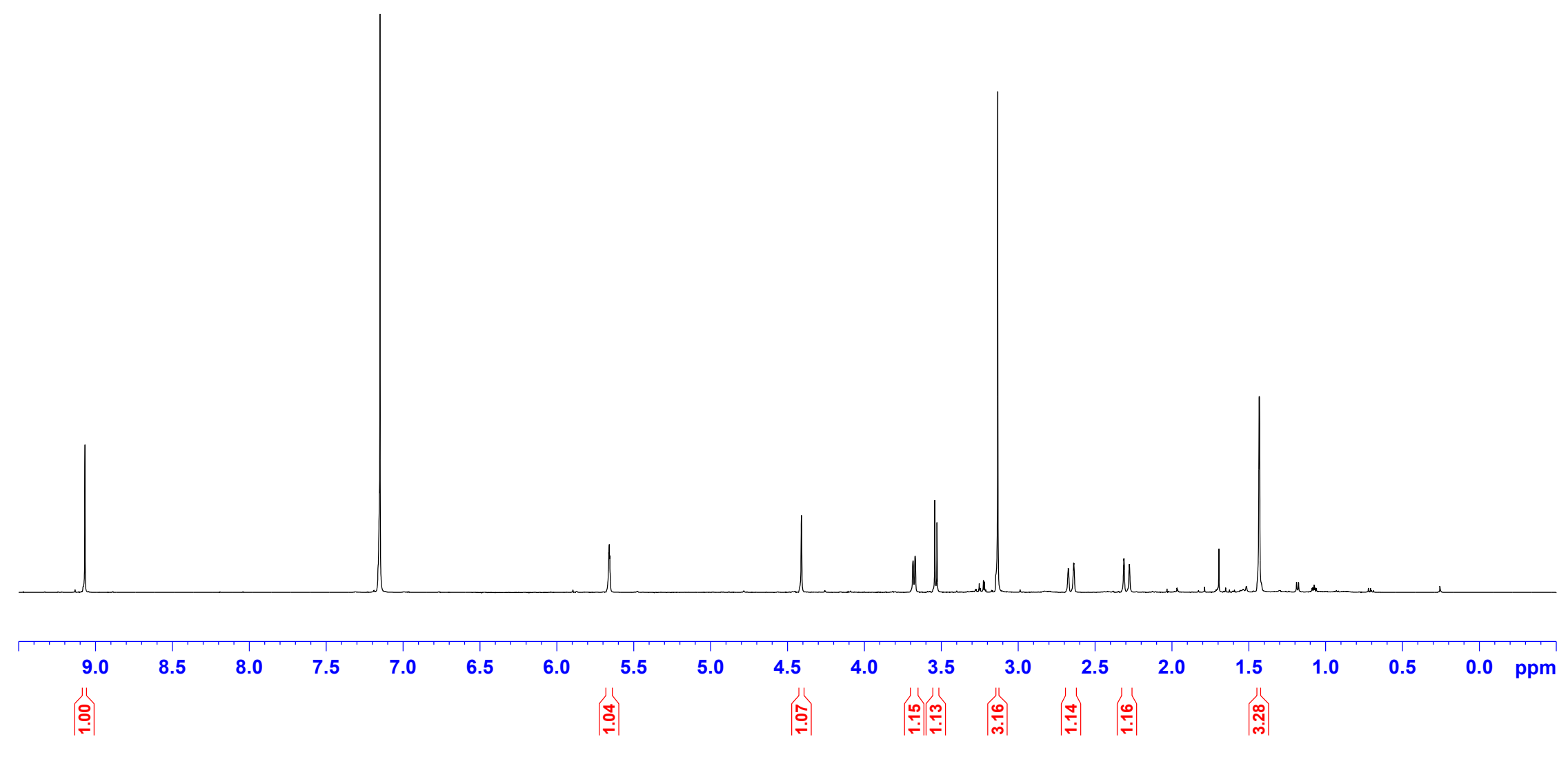




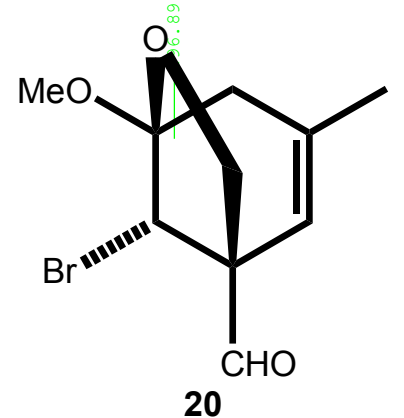

(CDCl, $125 \mathrm{MHz})$

DY-2-102

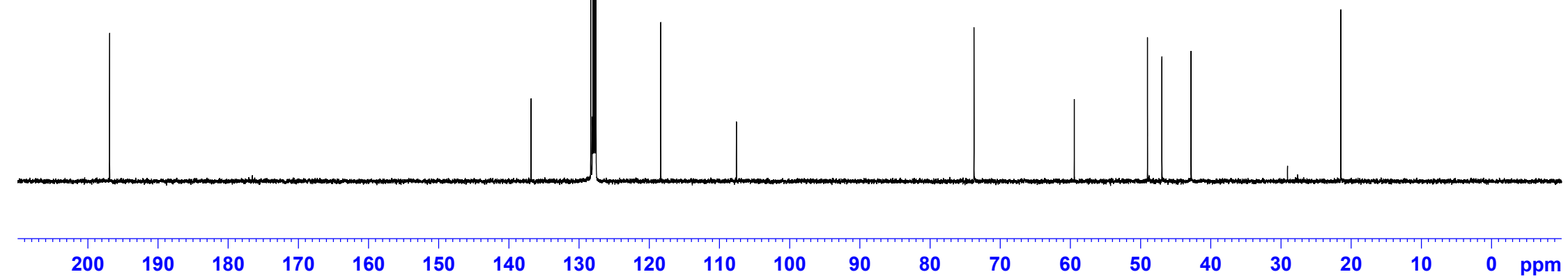




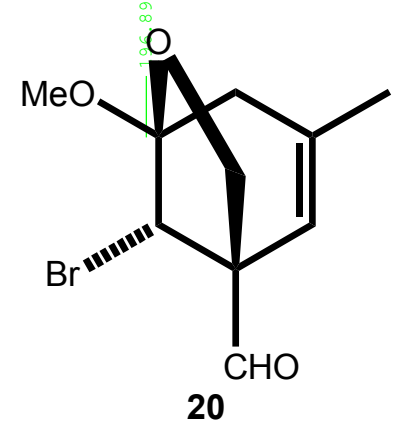

$\left(\mathrm{CDCl}_{3}, 125 \mathrm{MHz}\right)$

DY-2-102

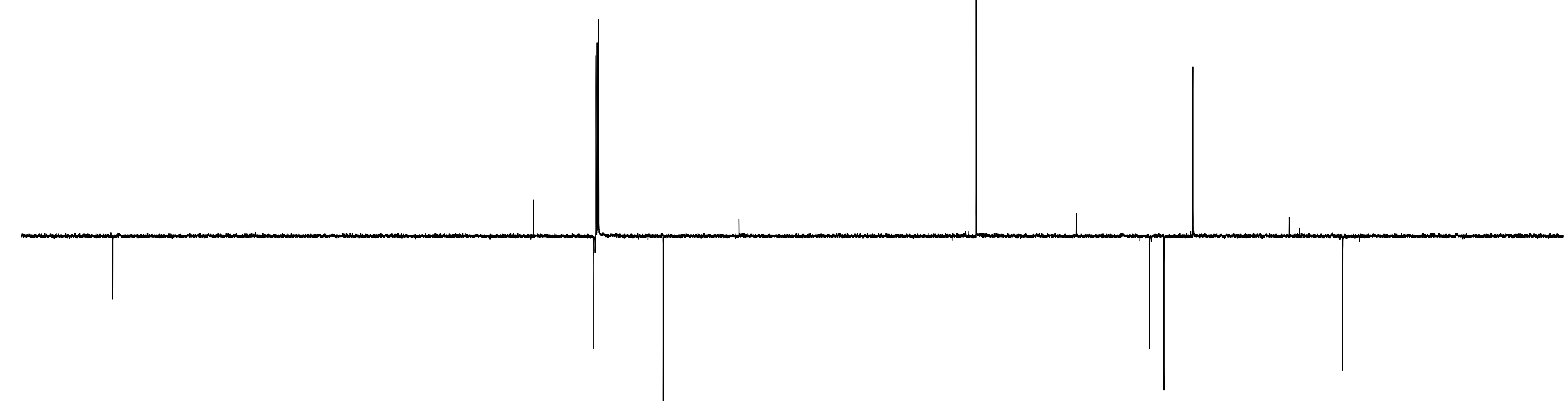




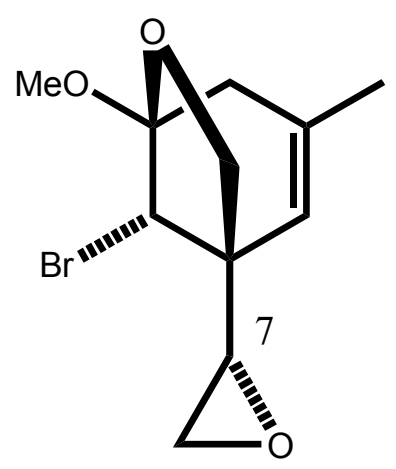

21

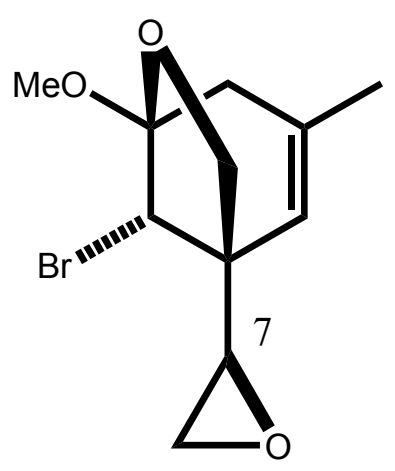

7-epi-21

Epoxides 21 and 7-epi-21. To a solution of $2.27 \mathrm{~g}(18.0 \mathrm{mmol})$ of dimethylsulfate in $6 \mathrm{~mL}$ of acetonitrile was added a solution of $1.23 \mathrm{~g}(19.8 \mathrm{mmol})$ of dimethylsulfide in $4 \mathrm{~mL}$ of acetonitrile. After stirring at $\mathrm{rt}$ overnight, the mixture was cooled in an ice-bath and $1.07 \mathrm{~g}(19.8 \mathrm{mmol})$ of sodium methoxide was added. After $30 \mathrm{~min}$, the mixture became a milky suspension. A solution of $3.13 \mathrm{~g}(12.0 \mathrm{mmol})$ of aldehyde 20 in $10 \mathrm{~mL}$ of acetonitrile was added dropwise. After stirring for $30 \mathrm{~min}$, the reaction gradually turned dark green. The suspension was concentrated in vacuo and the residue was washed with $10 \mathrm{~mL}$ of water. The aqueous phase was extracted with two 20-mL portions of dichloromethane. The combined organic phases were dried $\left(\mathrm{Na}_{2} \mathrm{SO}_{4}\right)$, filtered, and concentrated in vacuo. The residue was chromatographed over $20 \mathrm{~g}$ of silica gel (hexanes-ethyl acetate, $10: 1$ ) to afford $2.78 \mathrm{~g}$ ( $85 \%$ for three steps) of a 2:1 mixture of two epoxide diastereomers as a colorless oil. The oil was chromatographed again using MPLC (hexanes-ethyl acetate, 20:1) to afford $1.90 \mathrm{~g}(58 \%)$ of epoxide 21 and $0.94 \mathrm{~g} \mathrm{(29 \% )} \mathrm{of} \mathrm{7-epi-21} \mathrm{as}$ colorless oils. Epoxide 21: IR (neat) 3054, $1665 \mathrm{~cm}^{-1} ;{ }^{1} \mathrm{H}$ NMR $\left(\mathrm{C}_{6} \mathrm{D}_{6}, 500 \mathrm{MHz}\right) \delta 1.44(\mathrm{~s}, 3 \mathrm{H}$, $\left.\mathrm{CH}_{3}\right), 2.15(\mathrm{dd}, J=4.8,2.6 \mathrm{~Hz}, 1 \mathrm{H}, \mathrm{C} 8 \mathrm{H}), 2.29(\mathrm{dd}, J=4.8,4.2 \mathrm{~Hz}, 1 \mathrm{H}, \mathrm{C} 7 \mathrm{H}), 2.33(\mathrm{~d}, J=17.6 \mathrm{~Hz}$, $\left.1 \mathrm{H}, \mathrm{CH}_{2}\right), 2.65(\mathrm{dd}, J=4.1,2.7 \mathrm{~Hz}, 1 \mathrm{H}, \mathrm{C} 8 \mathrm{H}), 2.75\left(\mathrm{~d}, J=17.6 \mathrm{~Hz}, 1 \mathrm{H}, \mathrm{CH}_{2}\right), 3.15\left(\mathrm{~s}, 3 \mathrm{H}, \mathrm{OCH}_{3}\right)$, 3.63, $3.66\left(\mathrm{ABq}, J=7.1 \mathrm{~Hz}, 2 \mathrm{H}, \mathrm{CH}_{2} \mathrm{O}\right), 4.31(\mathrm{~s}, 1 \mathrm{H}, \mathrm{CHBr}), 5.02(\mathrm{~s}, 1 \mathrm{H},=\mathrm{CH}) ;{ }^{13} \mathrm{C} \operatorname{NMR}\left(\mathrm{C}_{6} \mathrm{D}_{6}\right.$, $125 \mathrm{MHz}) \delta 21.8(\mathrm{q}), 42.9(\mathrm{t}), 43.1(\mathrm{t}), 48.6(\mathrm{~s}), 48.9(\mathrm{q}), 50.3(\mathrm{~d}), 51.3(\mathrm{~d}), 75.2(\mathrm{t}), 107.5(\mathrm{~s}), 120.0$ (d), 136.6 (s); exact mass calcd. for $\mathrm{C}_{11} \mathrm{H}_{15}{ }^{79} \mathrm{BrO}_{3}(\mathrm{M}+\mathrm{Na})^{+} \mathrm{m} / \mathrm{z} 297.0102$, found $\mathrm{m} / \mathrm{z} 297.0111$. Anal. calcd. for $\mathrm{C}_{11} \mathrm{H}_{15} \mathrm{BrO}_{3}$ : C, 48.02; $\mathrm{H}, 5.50$. Found: $\mathrm{C}, 47.90 ; \mathrm{H}, 5.58$. Epoxide 7-epi-21: IR (neat) 3052, $1664 \mathrm{~cm}^{-1} ;{ }^{1} \mathrm{H}$ NMR $\left(\mathrm{C}_{6} \mathrm{D}_{6}, 500 \mathrm{MHz}\right) \delta 1.46$ (s, 3H, $\left.\mathrm{CH}_{3}\right), 2.21$ (app. t, $J=4.4 \mathrm{~Hz}, 1 \mathrm{H}$, $\mathrm{C} 7 \mathrm{H}$ ), $2.34\left(\mathrm{~d}, J=17.6 \mathrm{~Hz}, 1 \mathrm{H}, \mathrm{CH}_{2}\right.$ ), 2.57 (dd, $J=4.1,2.7 \mathrm{~Hz}, 1 \mathrm{H}, \mathrm{C} 8 \mathrm{H}$ ), 2.60 (dd, $J=4.7,2.7 \mathrm{~Hz}$, 
1H, C8H), $2.76\left(\mathrm{~d}, J=17.5 \mathrm{~Hz}, 1 \mathrm{H}, \mathrm{CH}_{2}\right), 3.15\left(\mathrm{~s}, 3 \mathrm{H}, \mathrm{OCH}_{3}\right), 3.69\left(\mathrm{~s}, 2 \mathrm{H}, \mathrm{CH}_{2} \mathrm{O}\right), 4.21(\mathrm{~s}, 1 \mathrm{H}$, $\mathrm{CHBr}), 5.17(\mathrm{~s}, 1 \mathrm{H},=\mathrm{CH}) ;{ }^{13} \mathrm{C}$ NMR $\left(\mathrm{C}_{6} \mathrm{D}_{6}, 125 \mathrm{MHz}\right) \delta 21.6(\mathrm{q}), 43.0(\mathrm{t}), 43.1$ (t) $47.9(\mathrm{~s}), 48.7(\mathrm{q})$, 49.1 (d), 51.9 (d), 75.4 (t), 107.7 (s), 121.9 (d), 135.9 (s); exact mass calcd. for $\mathrm{C}_{11} \mathrm{H}_{15}{ }^{79} \mathrm{BrO}_{3}$ $(\mathrm{M}+\mathrm{Na})^{+} \mathrm{m} / \mathrm{z}$ 297.0102, found $\mathrm{m} / \mathrm{z}$ 297.0117. Anal. calcd. for $\mathrm{C}_{11} \mathrm{H}_{15} \mathrm{BrO}_{3}: \mathrm{C}, 48.02 ; \mathrm{H}, 5.50$. Found: C, 48.08; H, 5.50. 


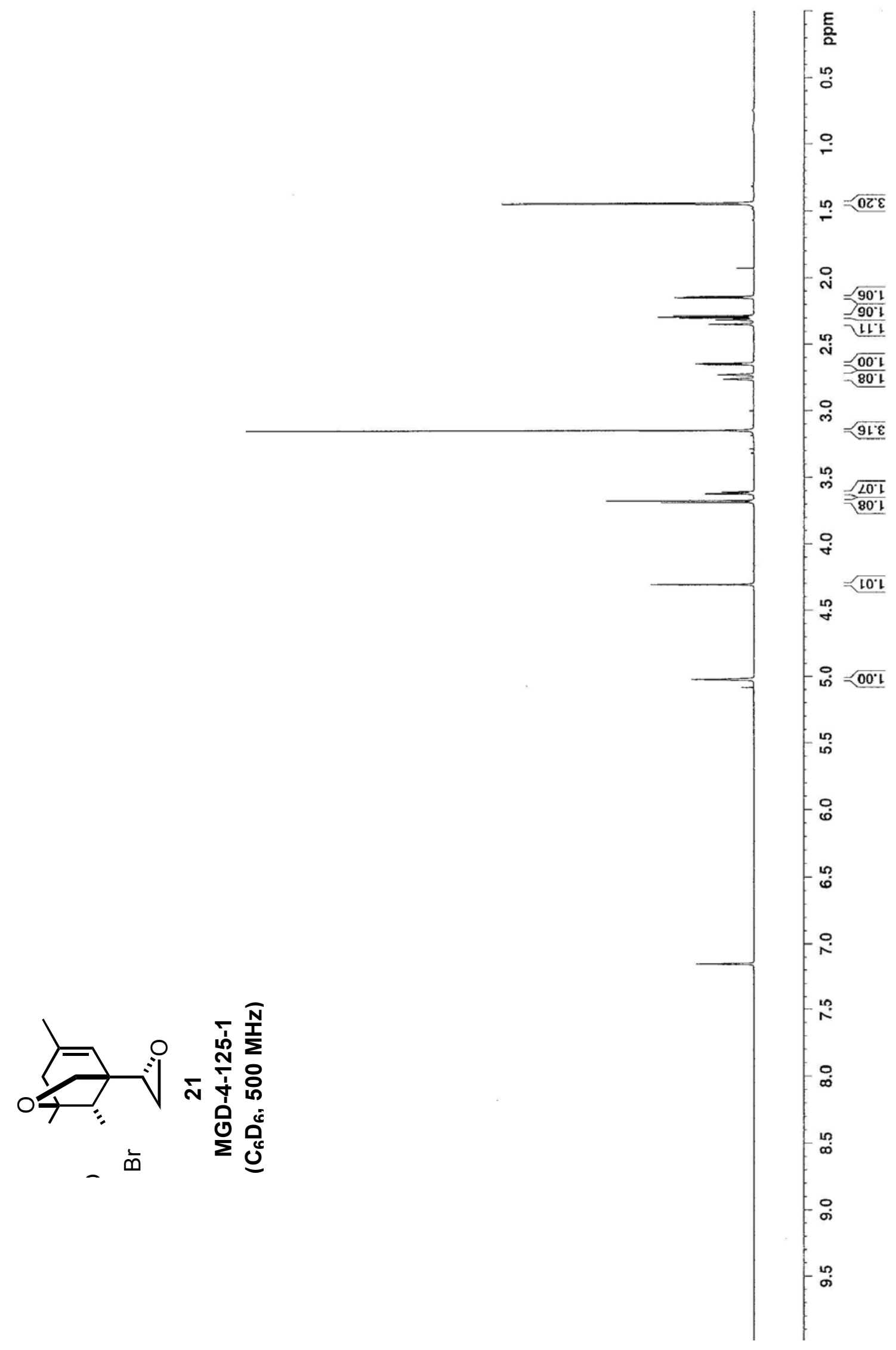



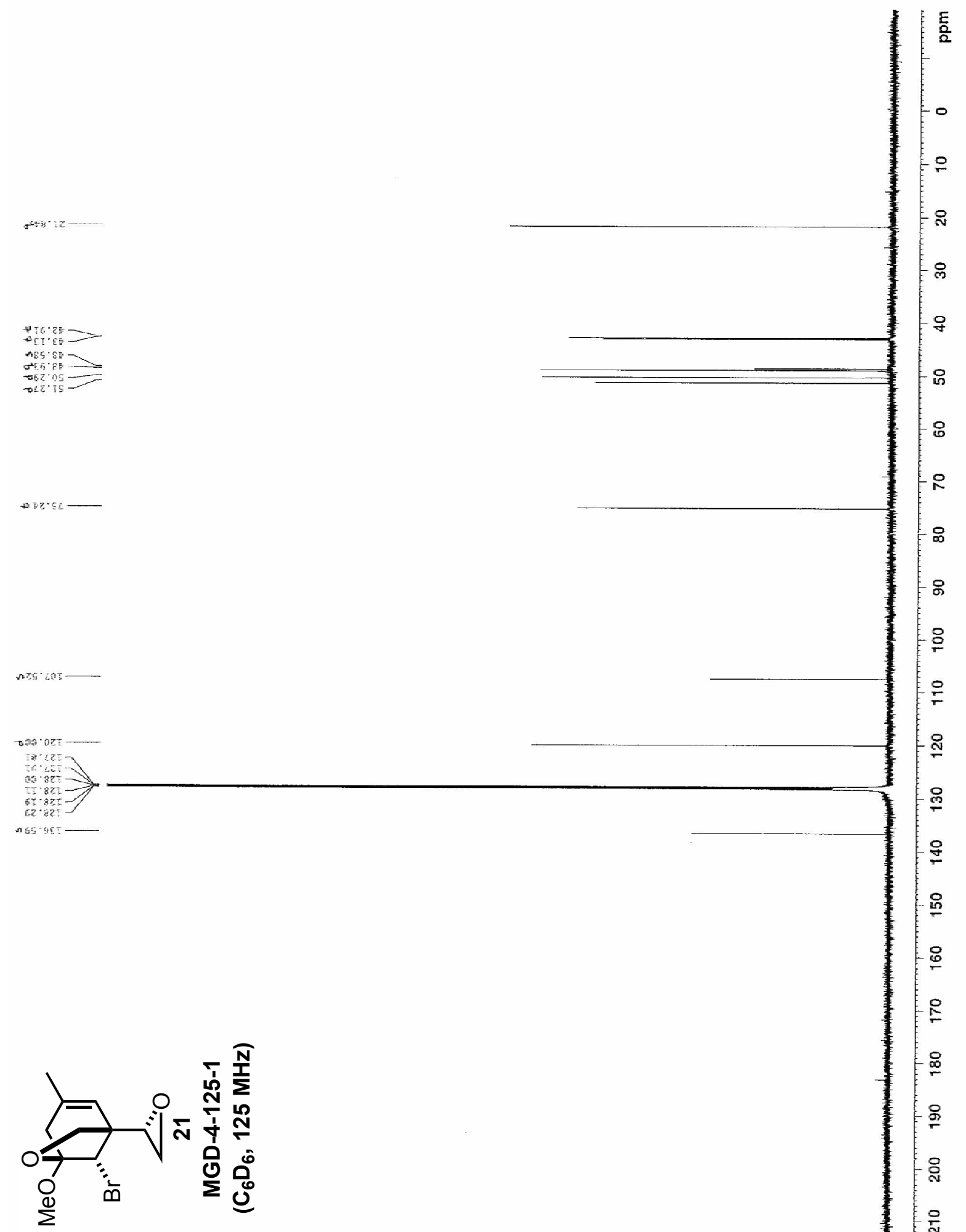

용 


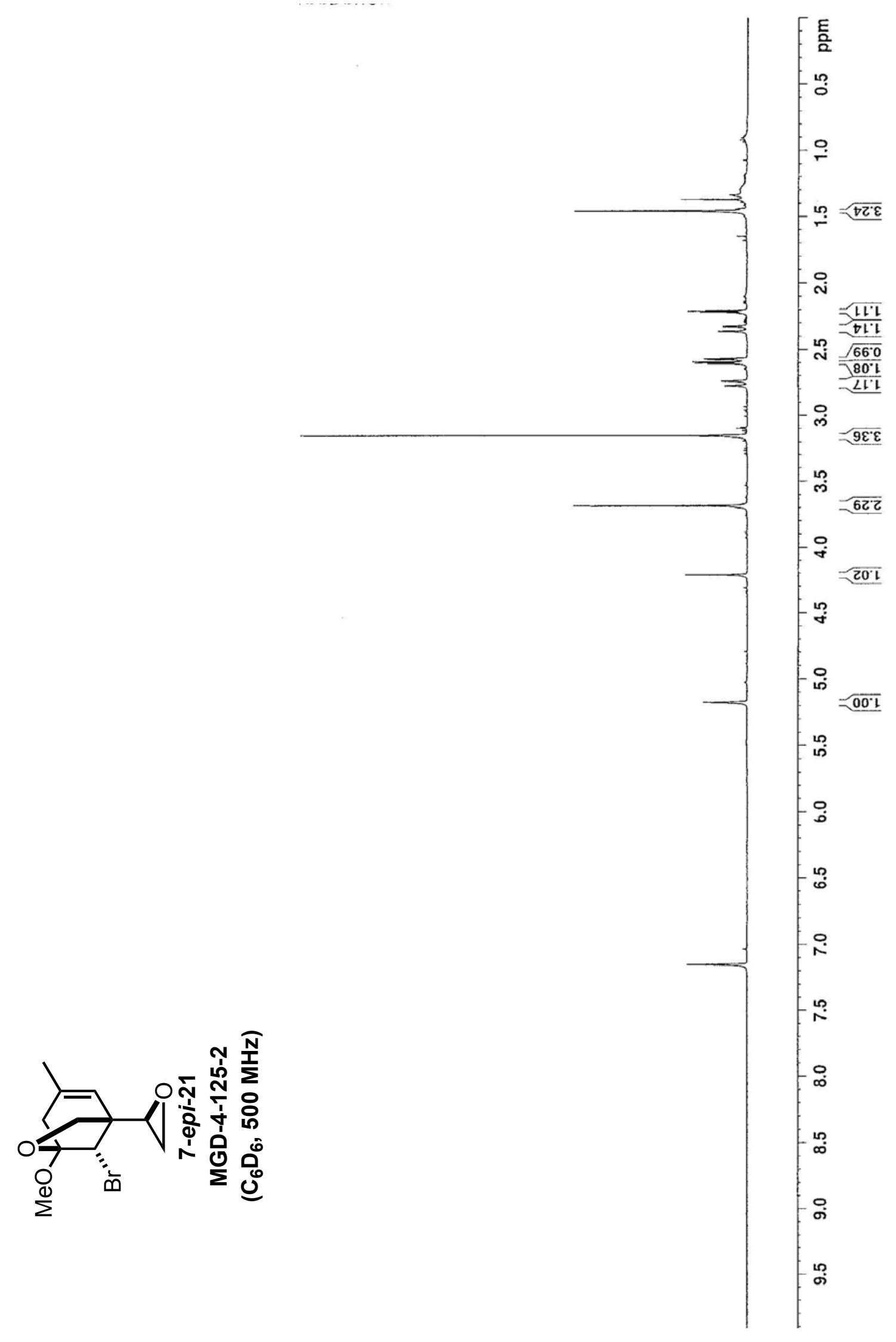




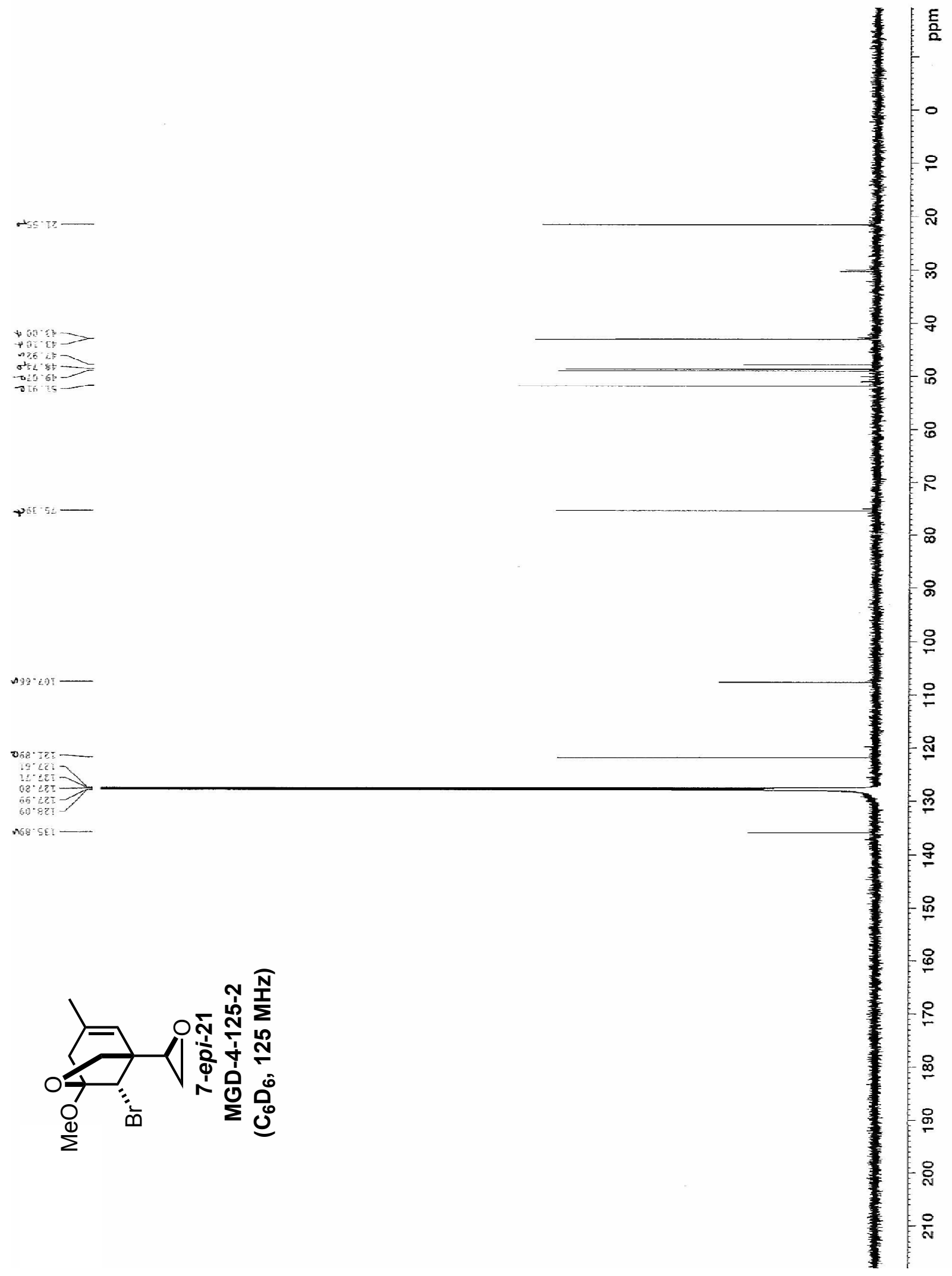




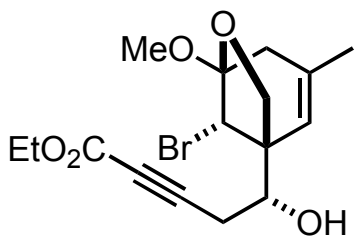

22

Alkynoate 22. To a solution of $784 \mathrm{mg}(7.99 \mathrm{mmol})$ of ethyl propiolate in $8 \mathrm{~mL}$ of freshly distilled tetrahydrofuran cooled to $-95{ }^{\circ} \mathrm{C}$ (ethyl acetate-liquid nitrogen) was added $3.2 \mathrm{~mL}(7.99 \mathrm{mmol})$ of 2.5 $\mathrm{M} \mathrm{n}$-butyllithium in hexanes and the mixture was stirred for $15 \mathrm{~min}$. To the solution was added $0.8 \mathrm{~mL}(0.91 \mathrm{~g}, 7.99 \mathrm{mmol})$ of borontrifluoride etherate via syringe followed by stirring for $15 \mathrm{~min}$. A solution of $440 \mathrm{mg}(1.6 \mathrm{mmol})$ of epoxide $21 \mathrm{in} 5 \mathrm{~mL}$ of dry tetrahydrofuran was then added via cannula, followed by one $1 \mathrm{~mL}$ tetrahydrofuran rinse. The mixture was stirred for $1.5 \mathrm{~h}$ at $-60{ }^{\circ} \mathrm{C}$ (dry ice-acetone). The solution was poured into $10 \mathrm{~mL}$ of saturated aqueous sodium bicarbonate. The aqueous phase was extracted with three $20-\mathrm{mL}$ portions of ethyl acetate. The combined organic phases were dried $\left(\mathrm{MgSO}_{4}\right)$, filtered, and concentrated in vacuo to give an amber oil. The amber oil was chromatographed over $50 \mathrm{~g}$ of silica gel (hexanes-ethyl acetate, $20: 1 \rightarrow 10: 1$ ) to afford $395 \mathrm{mg}(66 \%)$ of alkynoate 22 as a pale yellow crystalline solid: $\mathrm{mp} 83-85^{\circ} \mathrm{C}$; IR (thin film) 3444, 2239, $1711 \mathrm{~cm}^{-1} ;{ }^{1} \mathrm{H}$ NMR $\left(\mathrm{C}_{6} \mathrm{D}_{6}, 400 \mathrm{MHz}\right) \delta 1.03\left(\mathrm{t}, J=7.2 \mathrm{~Hz}, 3 \mathrm{H}, \mathrm{CH}_{2} \mathrm{C}_{3}\right), 1.59(\mathrm{~s}, 3 \mathrm{H}$, $\mathrm{CH}_{3}$ ), $2.02\left(\mathrm{dd}, J=17.4,9.4 \mathrm{~Hz}, 1 \mathrm{H}, \underline{\mathrm{C}}_{2} \mathrm{CH}\right.$ ), $2.34\left(\mathrm{dd}, J=17.2,2.4 \mathrm{~Hz}, 1 \mathrm{H}, \mathrm{C}_{2} \mathrm{CH}\right.$ ), 2.49 and $2.86\left(\mathrm{ABq}, J=20.6 \mathrm{~Hz}, 2 \mathrm{H}, \mathrm{CH}_{2}\right), 2.85(\mathrm{~s}, 1 \mathrm{H}, \mathrm{OH}), 3.34\left(\mathrm{~s}, 3 \mathrm{H}, \mathrm{OCH}_{3}\right), 3.78(\mathrm{~m}, 1 \mathrm{H}, \mathrm{CHOH}), 3.81$ (d, $\left.J=6.8 \mathrm{~Hz}, 1 \mathrm{H}, \mathrm{CH}_{2} \mathrm{O}\right), 4.05\left(\mathrm{q}, J=7.1 \mathrm{~Hz}, 2 \mathrm{H}, \mathrm{C}_{2} \mathrm{CH}_{3}\right), 4.16\left(\mathrm{~d}, J=6.8 \mathrm{~Hz}, 1 \mathrm{H}, \mathrm{CH}_{2} \mathrm{O}\right), 4.79$ (s, 1H, CHBr), $5.04(\mathrm{~m}, 1 \mathrm{H},=\mathrm{CH}) ;{ }^{13} \mathrm{C}$ NMR $\left(\mathrm{C}_{6} \mathrm{D}_{6}, 125 \mathrm{MHz}\right) \delta 13.7(\mathrm{q}), 21.8(\mathrm{q}), 23.0(\mathrm{t}), 43.1(\mathrm{t})$, $48.7(q), 49.7$ (d), 52.1 (s), 61.7 (t), 68.6 (d), $73.1(\mathrm{t}), 75.5$ (s), 86.1 (s), 107.1 (s), 121.3 (d), 136.6 (s), 153.6 (s); exact mass calcd. for $\mathrm{C}_{16} \mathrm{H}_{21}{ }^{79} \mathrm{BrO}_{5}(\mathrm{M}+\mathrm{Na})^{+} \mathrm{m} / \mathrm{z} 395.0470$, found $\mathrm{m} / \mathrm{z}$ 395.0462. Anal. calcd. for $\mathrm{C}_{16} \mathrm{H}_{21} \mathrm{BrO}_{5}$ : C, 51.49; $\mathrm{H}, 5.67$. Found: $\mathrm{C}, 52.05 ; \mathrm{H}, 5.89$. 


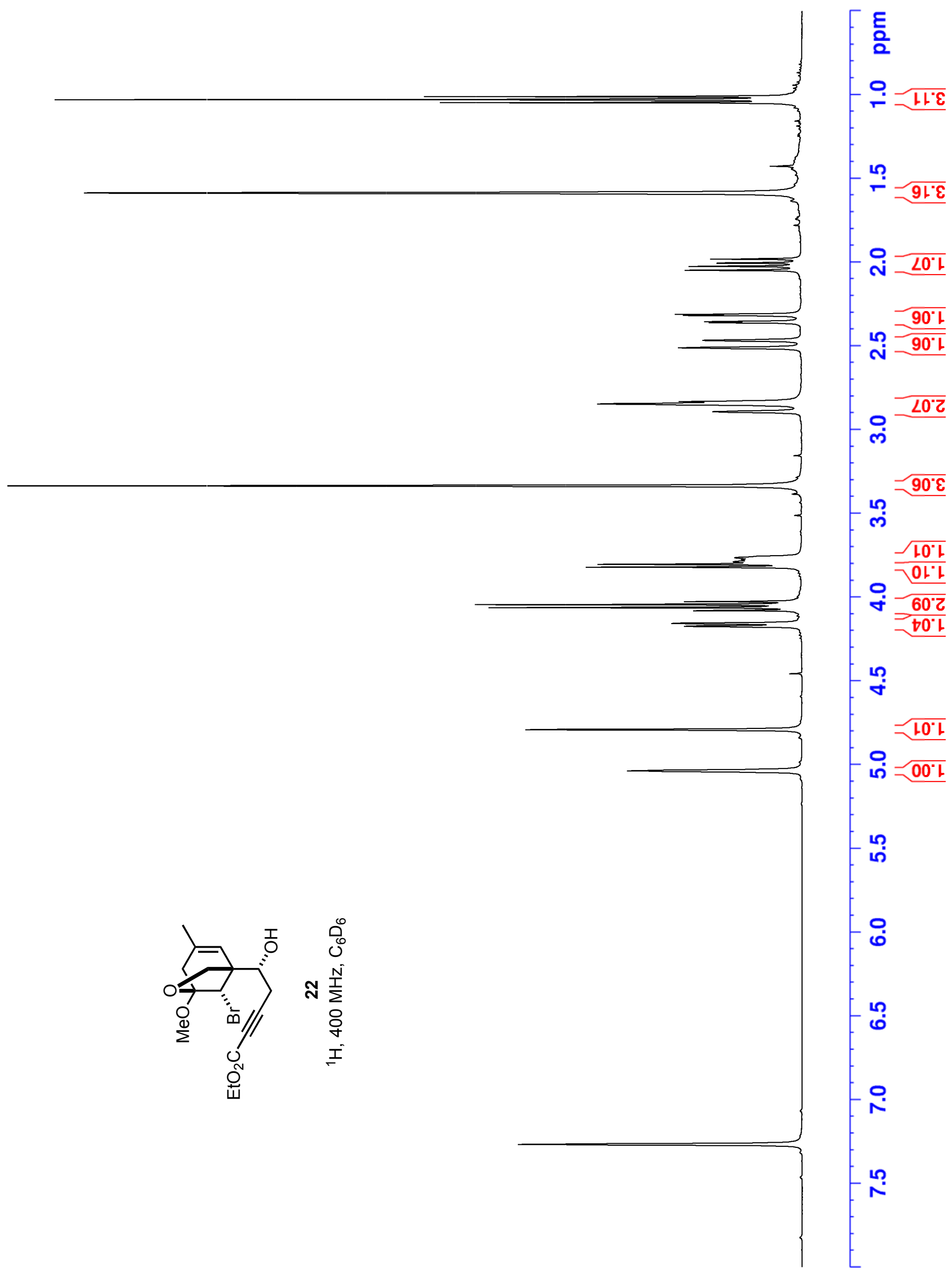




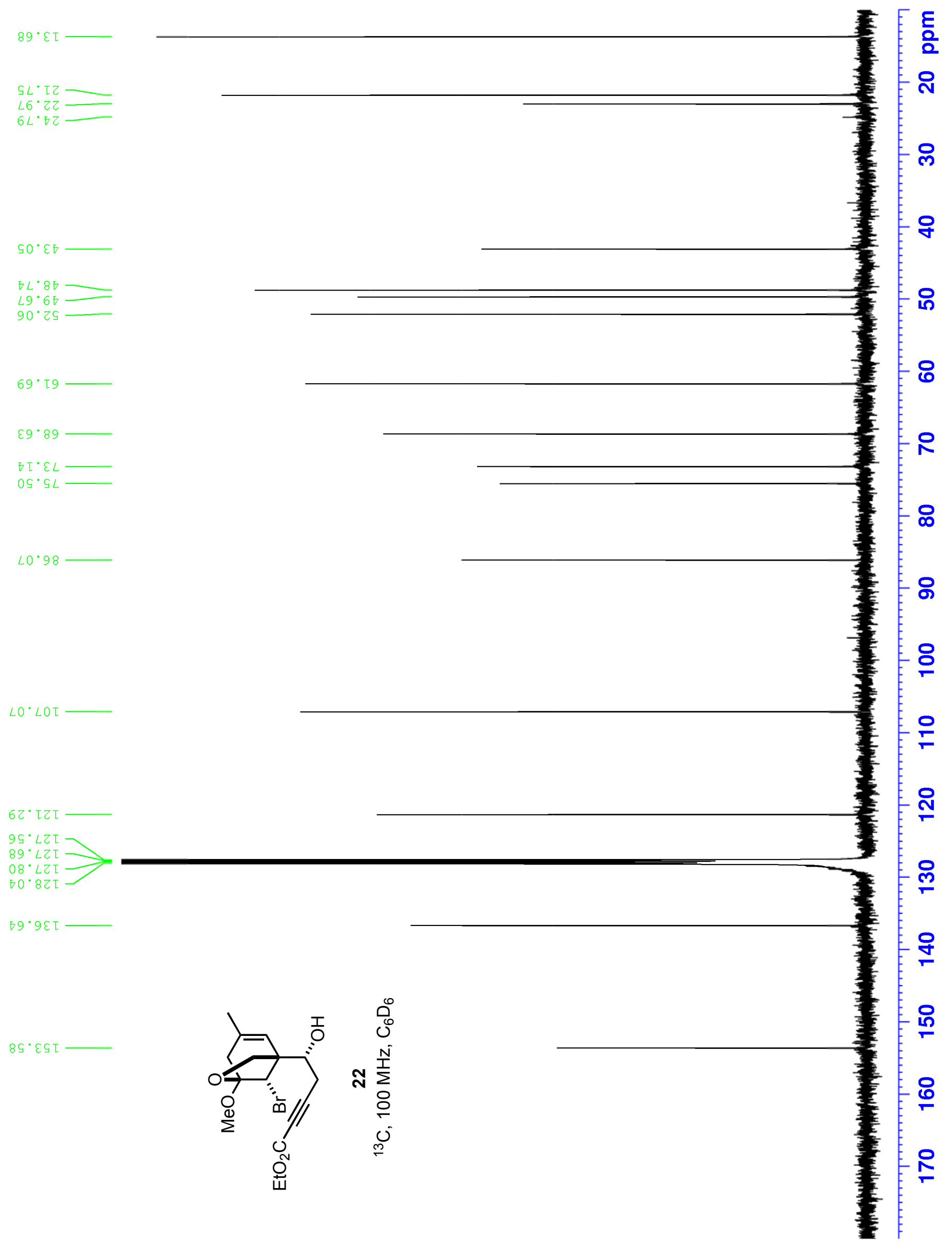




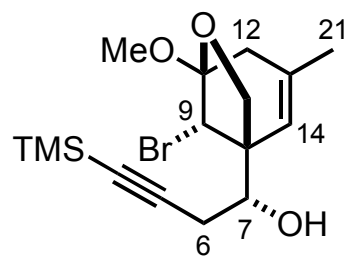

23

Acetylene 23. To a solution of $2.91 \mathrm{~mL}(2.02 \mathrm{~g}, 20.6 \mathrm{mmol})$ of trimethylsilylacetylene in $40 \mathrm{~mL}$ of dry tetrahydrofuran cooled to $-70^{\circ} \mathrm{C}$ (dry ice-acetone) was added $8.23 \mathrm{~mL}(20.6 \mathrm{mmol})$ of $2.5 \mathrm{M} \mathrm{n}$-butyllithium (hexanes) via syringe. After $15 \mathrm{~min}, 2.61 \mathrm{~mL}(2.92 \mathrm{~g}, 20.6 \mathrm{mmol})$ of boron trifluoride diethyl etherate was added via syringe. After $10 \mathrm{~min}$, a solution of $0.71 \mathrm{~g}(2.6 \mathrm{mmol})$ of epoxide 21 in $10 \mathrm{~mL}$ of dry tetrahydrofuran cooled in a dry ice-acetone bath was added via cannula (followed by a $10 \mathrm{~mL}$ rinse with dry tetrahydrofuran). After $30 \mathrm{~min}, 25 \mathrm{~mL}$ of saturated aqueous sodium bicarbonate was added. The aqueous phase was extracted with three $50-\mathrm{mL}$ portions of diethyl ether. The combined organic phases were washed with $50 \mathrm{~mL}$ of brine, dried $\left(\mathrm{MgSO}_{4}\right)$, filtered, and concentrated in vacuo. The residue was chromatographed over $25 \mathrm{~g}$ of silica gel (hexanes-ethyl acetate, 20:1) to afford $475 \mathrm{mg}(50 \%)$ of alkyne 23 as a yellow oil: ${ }^{1} \mathrm{H}$ $\operatorname{NMR}\left(\mathrm{C}_{6} \mathrm{D}_{6}, 500 \mathrm{MHz}\right) \delta 0.28\left(\mathrm{~s}, 9 \mathrm{H}, \mathrm{Si}\left(\mathrm{CH}_{3}\right)_{3}\right), 0.57$ (br s, 1H, OH), $1.58\left(\mathrm{~s}, 3 \mathrm{H}, \mathrm{C}(21) \mathrm{H}_{3}\right), 2.12$ (dd, $J=17.0,8.8 \mathrm{~Hz}, 1 \mathrm{H}, \mathrm{C}(6) \mathrm{H}), 2.44(\mathrm{dd}, J=17.0,3.3 \mathrm{~Hz}, 1 \mathrm{H}, \mathrm{C}(6) \mathrm{H}), 2.62,2.81\left(\mathrm{AB}_{\mathrm{q}}, J=17.5 \mathrm{~Hz}\right.$, $\left.2 \mathrm{H}, \mathrm{C}(12) \mathrm{H}_{2}\right), 3.34\left(\mathrm{~s}, 3 \mathrm{H}, \mathrm{OCH}_{3}\right), 3.82(\mathrm{dm}, J=8.7 \mathrm{~Hz}, 1 \mathrm{H}, \mathrm{C}(7) \mathrm{H}), 3.91(\mathrm{~d}, J=6.8 \mathrm{~Hz}, 1 \mathrm{H}$, $\mathrm{C}(20) \mathrm{H}), 4.22(\mathrm{~d}, J=6.8 \mathrm{~Hz}, 1 \mathrm{H}, \mathrm{C}(20) \mathrm{H}), 4.88(\mathrm{~s}, 1 \mathrm{H}, \mathrm{C}(9) \mathrm{H}), 5.15(\mathrm{~s}, 1 \mathrm{H}, \mathrm{C}(14) \mathrm{H}) ;{ }^{13} \mathrm{C} N M R$ $\left(\mathrm{C}_{6} \mathrm{D}_{6}, 125 \mathrm{MHz}\right) \delta-0.2(\mathrm{q}), 21.8(\mathrm{q}), 24.3(\mathrm{t}), 43.1(\mathrm{t}), 48.7(\mathrm{q}), 49.9(\mathrm{~d}), 52.0(\mathrm{~s}), 68.8(\mathrm{~d}), 73.2(\mathrm{t})$, 87.9 (s), 103.5 (s), 107.0 (s), 121.6 (d), 136.4 (s); exact mass calcd. for $\mathrm{C}_{16} \mathrm{H}_{25} \mathrm{BrO}_{3} \mathrm{Si}(\mathrm{M}+\mathrm{Na})^{+} \mathrm{m} / \mathrm{z}$ 395.0654, found $m / z 395.0657$. 


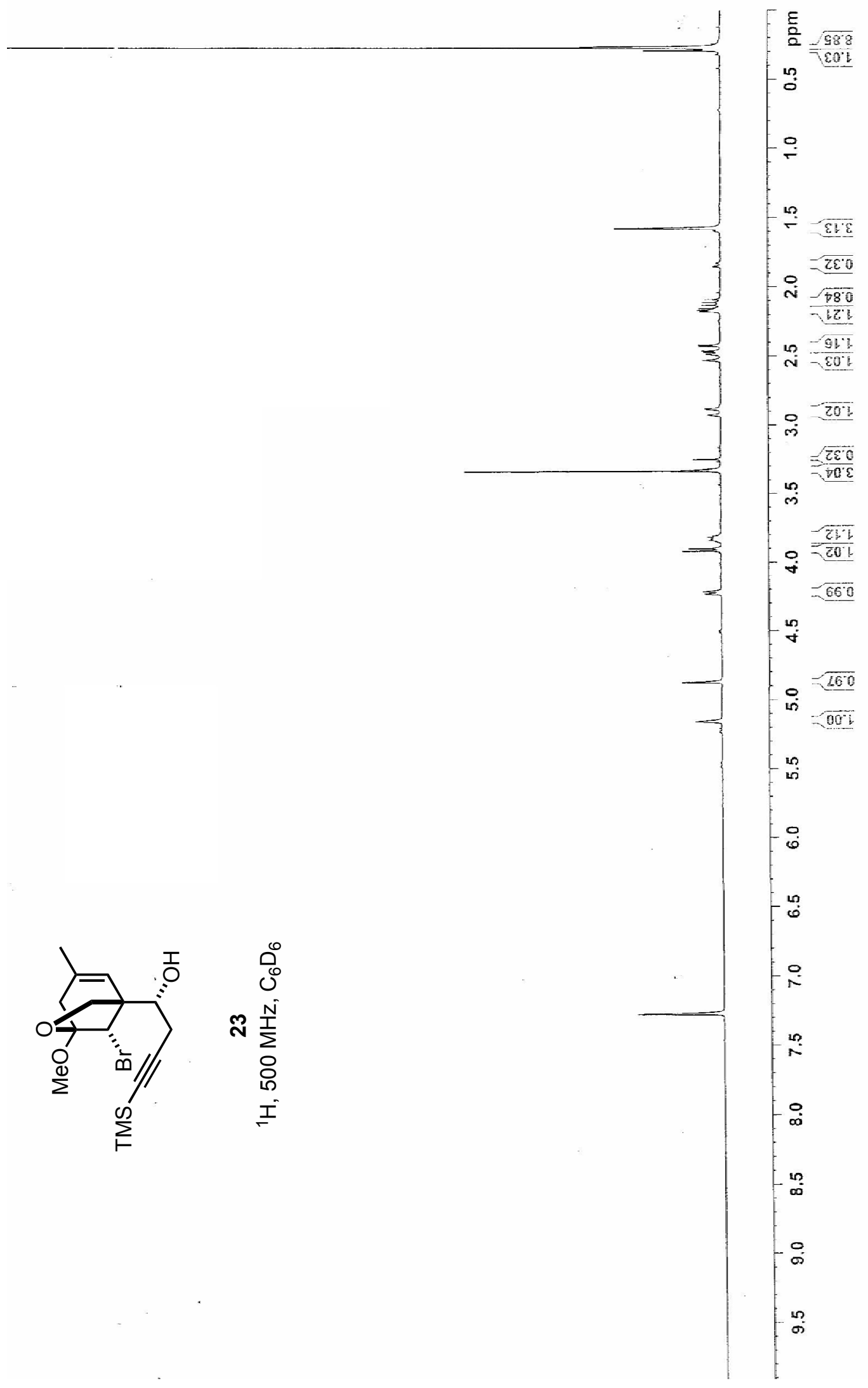




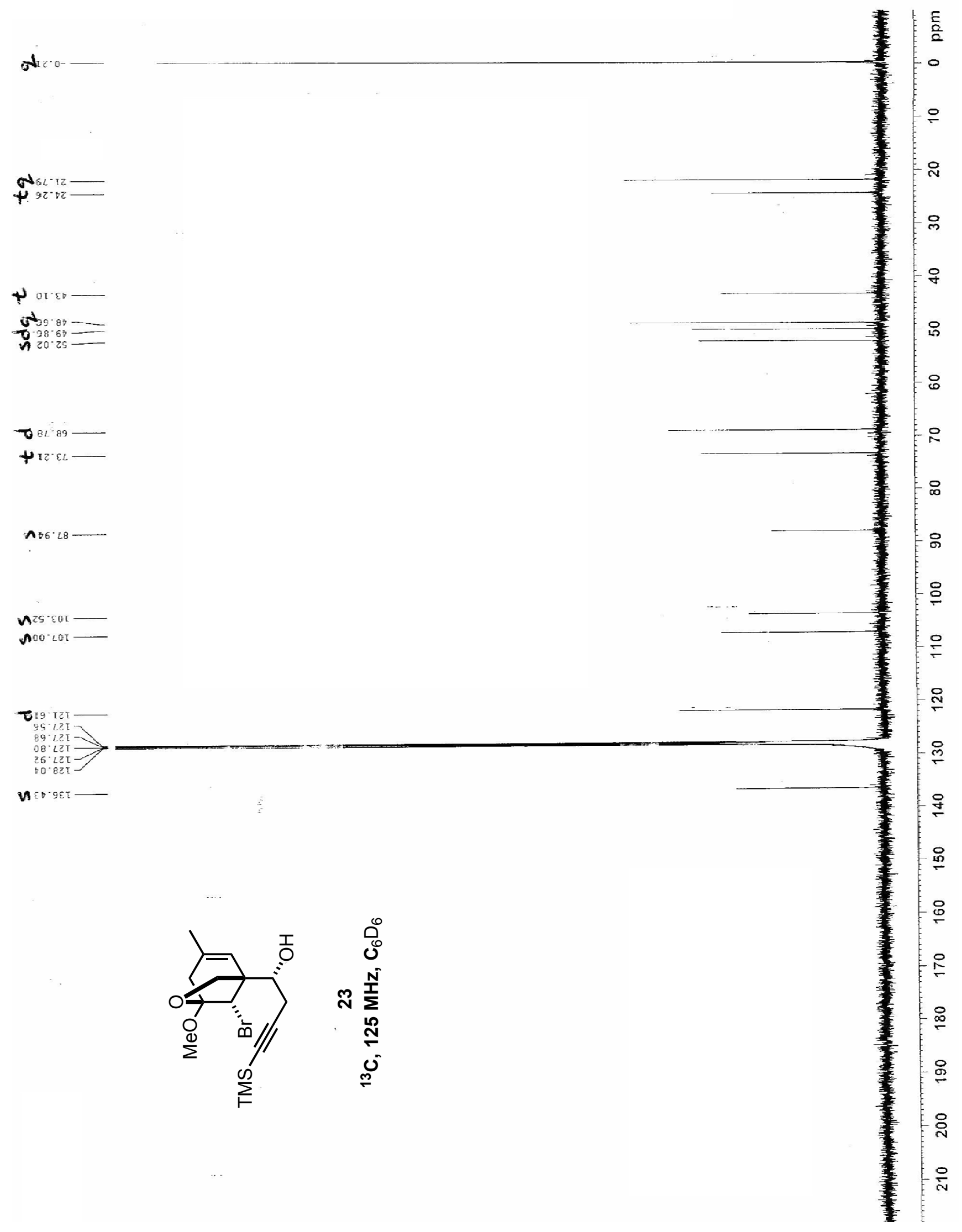




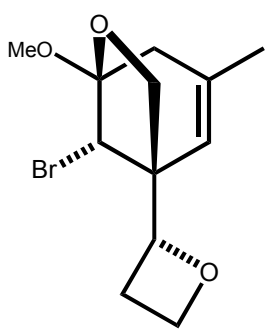

24

Oxetane 24. To a solution of $1.20 \mathrm{~g}(5.46 \mathrm{mmol})$ of trimethyloxosulfonium iodide in $10 \mathrm{~mL}$ of $t$ - $\mathrm{BuOH}$ was added $0.61 \mathrm{~g}(5.46 \mathrm{mmol})$ of $t-\mathrm{BuOK}$ under $\mathrm{N}_{2}$ at rt. The mixture was warmed at 50 ${ }^{\circ} \mathrm{C}$ for 30 min during which time the reaction mixture became milky. A solution of $0.50 \mathrm{~g}(1.8$ mmol) of epoxide 21 in $10 \mathrm{~mL}$ of $t$-BuOH was added by addition funnel, followed by a $2 \mathrm{~mL} t$-BuOH rinse. The resulting suspension was stirred for $16 \mathrm{~h}$, concentrated in vacuo, washed with $15 \mathrm{~mL}$ of $\mathrm{H}_{2} \mathrm{O}$, and extracted with three $20-\mathrm{mL}$ portions of $\mathrm{CH}_{2} \mathrm{Cl}_{2}$. The combined organic extracts were dried $\left(\mathrm{Na}_{2} \mathrm{SO}_{4}\right)$ and concentrated in vacuo. The residual pale yellow oil was purified by chromatography over $20 \mathrm{~g}$ of silica gel (hexanes-ethyl acetate, $5: 1)$ to afford $0.38 \mathrm{~g}(73 \%)$ of oxetane 24 as a colorless oil. IR (neat) 2967, $1664 \mathrm{~cm}^{-1} ;{ }^{1} \mathrm{H}$ NMR $\left(\mathrm{C}_{6} \mathrm{D}_{6}, 500 \mathrm{MHz}\right) \delta 1.47$ (s, 3H, $\left.\mathrm{CH}_{3}\right), 2.42$ and $2.85\left(\mathrm{ABq}, J=17.5 \mathrm{~Hz}, 2 \mathrm{H}, \mathrm{CH}_{2}\right), 2.04$ and $2.59\left(\mathrm{~m}, 2 \mathrm{H}, \mathrm{C}_{8} \mathrm{H}_{2}\right), 3.22\left(\mathrm{~s}, 3 \mathrm{H}, \mathrm{OCH}_{3}\right)$, 3.76 and $4.00\left(\mathrm{ABq}, J=7.0 \mathrm{~Hz}, 2 \mathrm{H}, \mathrm{CH}_{2} \mathrm{O}\right), 4.28$ and $4.32\left(\mathrm{~m}, 2 \mathrm{H}, \mathrm{C}_{9} \mathrm{H}_{2}\right), 4.56(\mathrm{t}, J=8.0 \mathrm{~Hz}, 1 \mathrm{H}$, $\left.\mathrm{C}_{7} \mathrm{H}\right), 4.67(\mathrm{~s}, 1 \mathrm{H}, \mathrm{CHBr}), 5.12(\mathrm{~s}, 1 \mathrm{H},=\mathrm{CH}) ;{ }^{13} \mathrm{C} N M R\left(\mathrm{C}_{6} \mathrm{D}_{6}, 125 \mathrm{MHz}\right) \delta 21.6(\mathrm{q}), 21.9(\mathrm{t}), 43.2(\mathrm{t})$, $47.5(\mathrm{~d}), 48.7(\mathrm{q}), 50.9(\mathrm{~s}), 68.2(\mathrm{t}), 74.2(\mathrm{t}), 80.6(\mathrm{~d}), 107.7(\mathrm{~s}), 121.2(\mathrm{~d}), 136.1(\mathrm{~s})$; exact mass calcd. for $\mathrm{C}_{12} \mathrm{H}_{17}{ }^{79} \mathrm{BrO}_{2}(\mathrm{M}+\mathrm{Na})^{+} \mathrm{m} / \mathrm{z} 311.0259$, found $\mathrm{m} / \mathrm{z}$ 311.0251. This material contained a trace contaminant by NMR, but was suitable for use in the next reaction. 


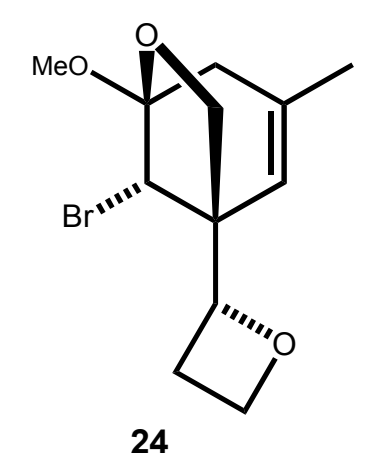

$\left(\mathrm{C}_{6} \mathrm{D}_{6}, 500 \mathrm{MHz}\right)$

DY-2-97

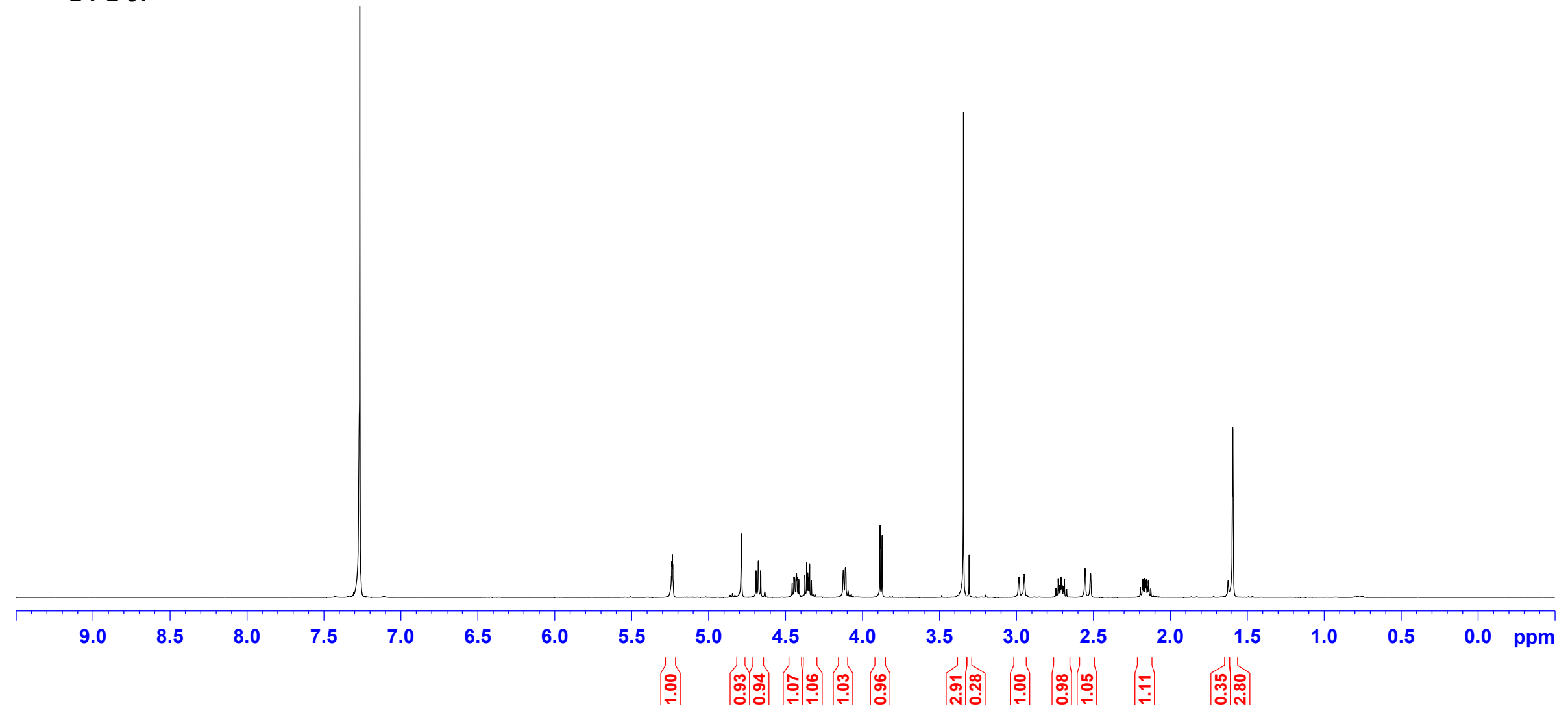




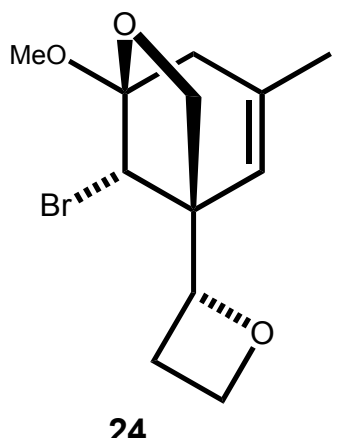

$\left(\mathrm{C}_{6} \mathrm{D}_{6}, 500 \mathrm{MHz}\right)$ DY-2-97

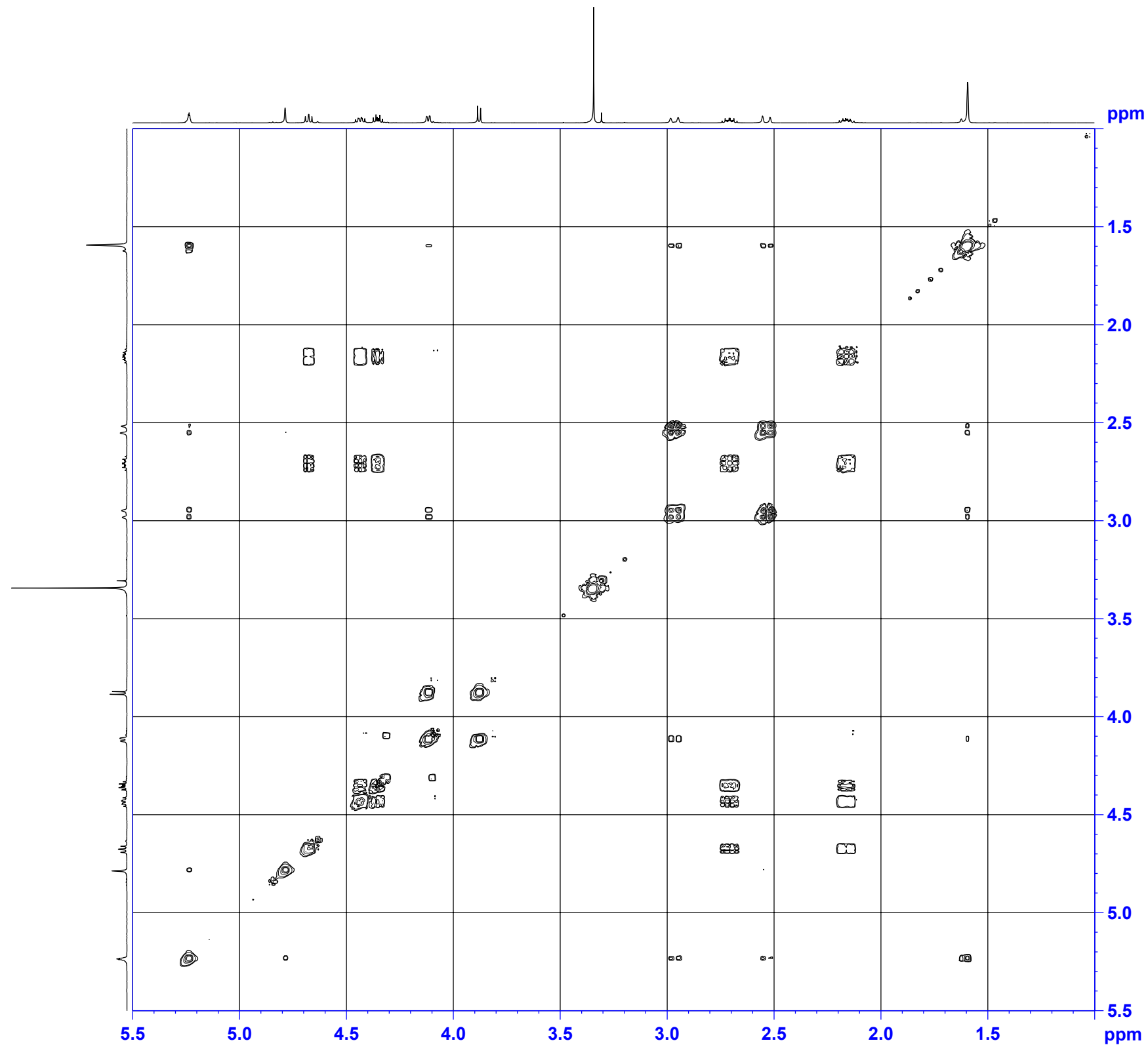

68 


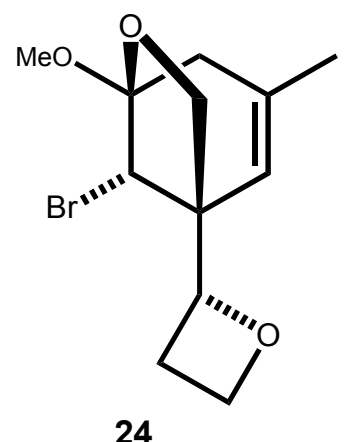

$\left(\mathrm{C}_{6} \mathrm{D}_{6}, 125 \mathrm{MHz}\right)$

DY-2-97 


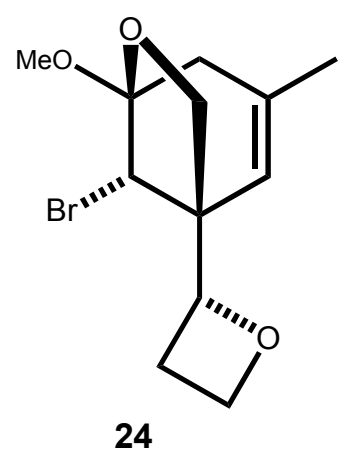

$\left(\mathrm{C}_{6} \mathrm{D}_{6}, 125 \mathrm{MHz}\right)$

DY-2-97

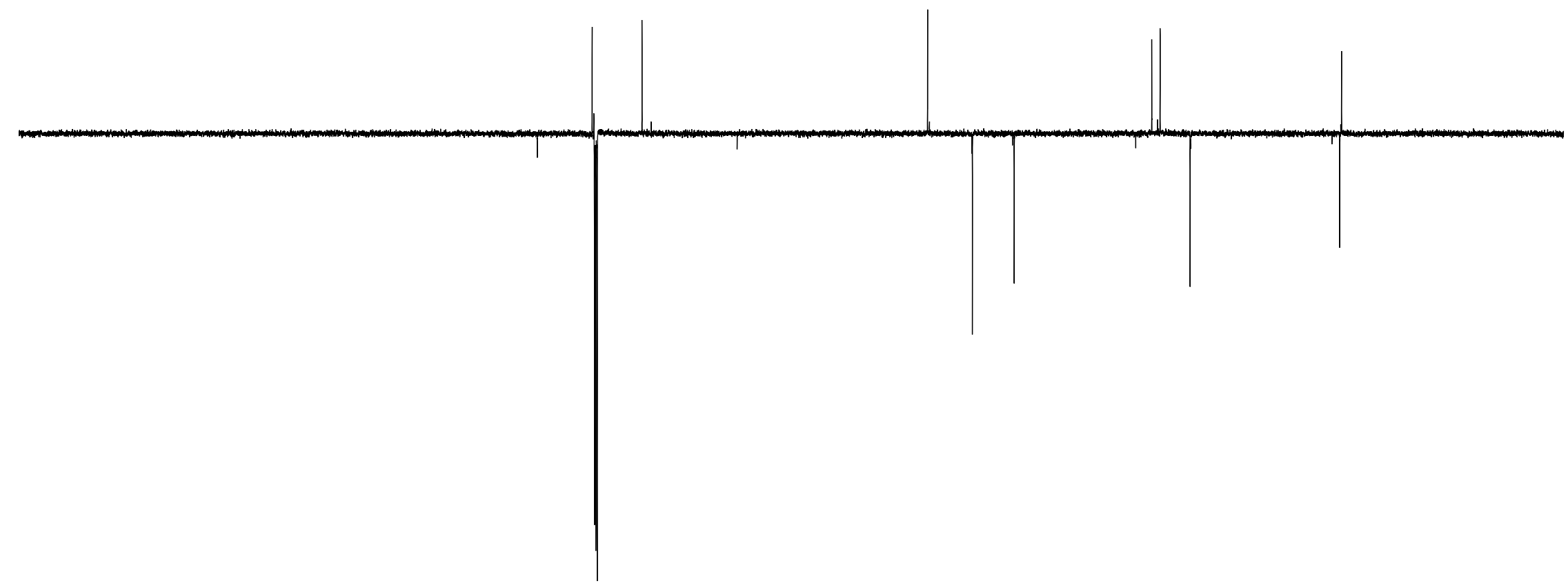



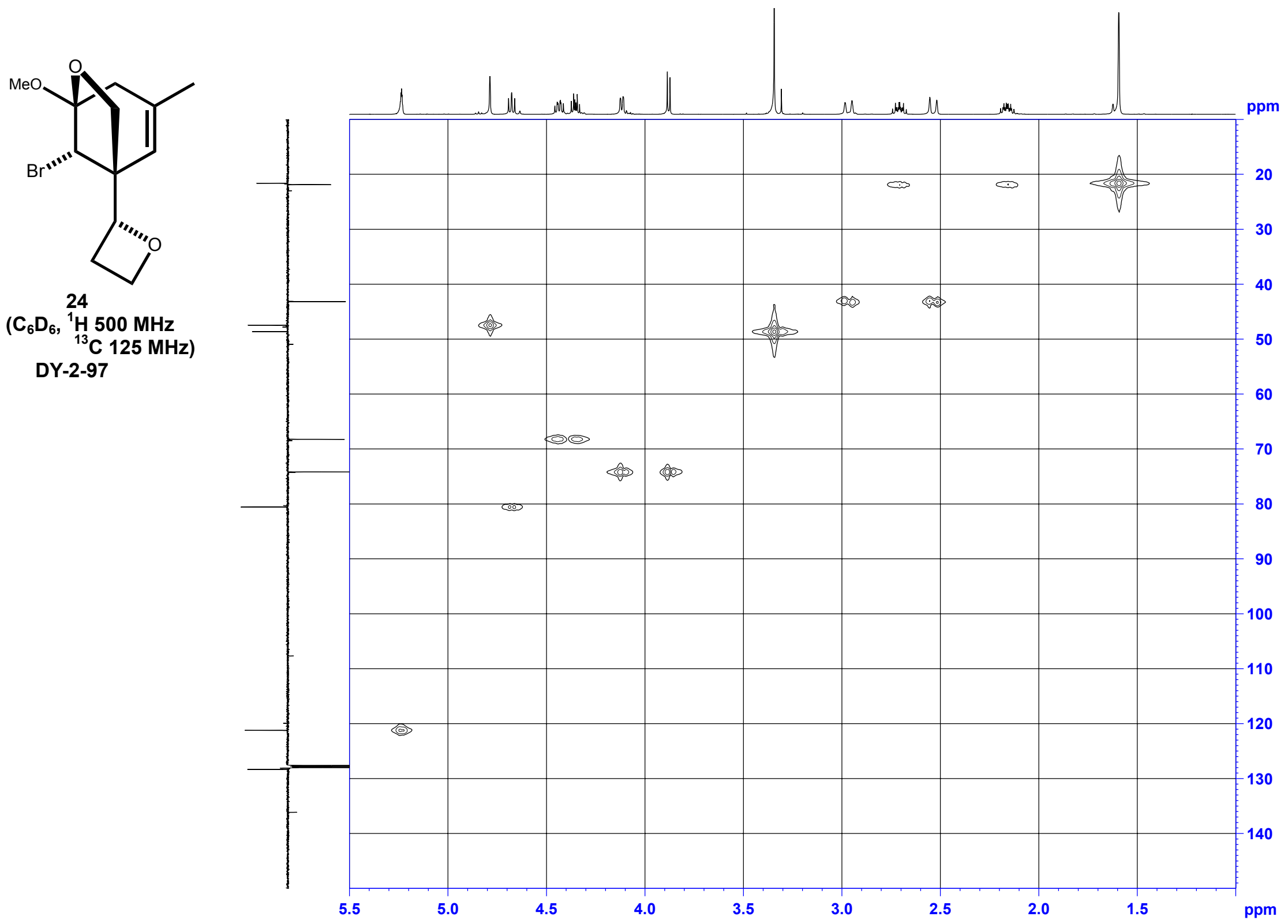


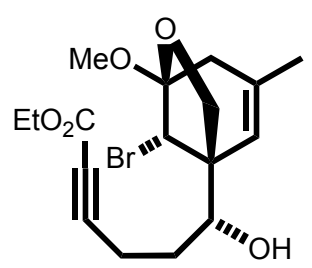

25

Alkyne 25. To a solution of $0.182 \mathrm{~g}(1.86 \mathrm{mmol})$ of ethyl propiolate in $2 \mathrm{~mL}$ of dry tetrahydrofuran cooled to $-85^{\circ} \mathrm{C}$ (dry ice-ethyl acetate) was added $0.75 \mathrm{~mL}(1.86 \mathrm{mmol})$ of $2.5 \mathrm{M} \mathrm{n}$-butyllithium in hexanes. The mixture was stirred for $15 \mathrm{~min}$ and $0.22 \mathrm{~mL}(0.21 \mathrm{~g}, 1.86 \mathrm{mmol})$ of boron trifluoride etherate was added by syringe. The mixture was stirred for $15 \mathrm{~min}$ and a solution of $0.27 \mathrm{~g} \mathrm{(0.93}$ $\mathrm{mmol}$ ) of oxetane $24 \mathrm{in} 1.0 \mathrm{~mL}$ of dry tetrahydrofuran was added by syringe (followed by two 0.2-mL tetrahydrofuran rinses). The solution was stirred for $2 \mathrm{~h}$ and the temperature was then slowly raised to rt over 30 min period. The mixture was then poured into $2 \mathrm{~mL}$ of saturated aqueous sodium bicarbonate. The aqueous phase was extracted with three 5-mL portions of dichloromethane. The combined organic phases were washed with $5 \mathrm{~mL}$ of brine, dried $\left(\mathrm{Na}_{2} \mathrm{SO}_{4}\right)$, filtered, and concentrated in vacuo. The residue was purified by chromatography over $10 \mathrm{~g}$ of silica gel (hexanes-ethyl acetate, 5:1) to give $330 \mathrm{mg}(92 \%)$ of alkynes 25 as colorless oil. Due to instability of pure alkyne 25 in air, only NMR spectra data were collected. ${ }^{1} \mathrm{H} N M R\left(C_{6} D_{6}\right.$, $500 \mathrm{MHz}) \delta 0.87\left(\mathrm{t}, J=7.0 \mathrm{~Hz}, 3 \mathrm{H}, \mathrm{CH}_{2} \mathrm{CH}_{3}\right), 0.92$ and $1.39\left(\mathrm{~m}, 2 \mathrm{H}, \mathrm{C}(8) \mathrm{H}_{2}\right), 1.30(\mathrm{~d}, J=6 \mathrm{~Hz}, 1 \mathrm{H}$, $\mathrm{OH}), 1.48\left(\mathrm{~s}, 3 \mathrm{H}, \mathrm{CH}_{3}\right), 1.88$ and $1.98\left(\mathrm{~m}, 2 \mathrm{H}, \mathrm{C}(9) \mathrm{H}_{2}\right), 2.39$ and $2.78\left(\mathrm{ABq}, J=17.5 \mathrm{~Hz}, 2 \mathrm{H}, \mathrm{CH}_{2}\right)$, $3.23\left(\mathrm{~s}, 3 \mathrm{H}, \mathrm{OCH}_{3}\right), 3.37(\mathrm{~m}, 1 \mathrm{H}, \mathrm{C} \underline{\mathrm{HOH}}), 3.58$ and $3.88\left(\mathrm{ABq}, J=6.5 \mathrm{~Hz}, 2 \mathrm{H}, \mathrm{CH}_{2} \mathrm{O}\right), 3.91$ (q, $J=$ $\left.7.0 \mathrm{~Hz}, 2 \mathrm{H}, \mathrm{CH}_{2} \mathrm{CH}_{3}\right), 4.62(\mathrm{~s}, 1 \mathrm{H}, \mathrm{CHBr}), 4.98(\mathrm{~s}, 1 \mathrm{H},=\mathrm{CH}) ;{ }^{13} \mathrm{C} N M R\left(\mathrm{C}_{6} \mathrm{D}_{6}, 125 \mathrm{MHz}\right) \delta 13.7$ (q), $15.7(\mathrm{t}), 21.7(\mathrm{q}), 29.5(\mathrm{t}), 43.0(\mathrm{t}), 48.7(\mathrm{q}), 49.8(\mathrm{q}), 52.4(\mathrm{~s}), 61.4(\mathrm{t}), 69.0(\mathrm{~d}), 72.9(\mathrm{t}), 74.6(\mathrm{~s})$, 87.7 (s), 107.0 (s), 122.1 (d), 136.3 (s), 153.5 (s). 

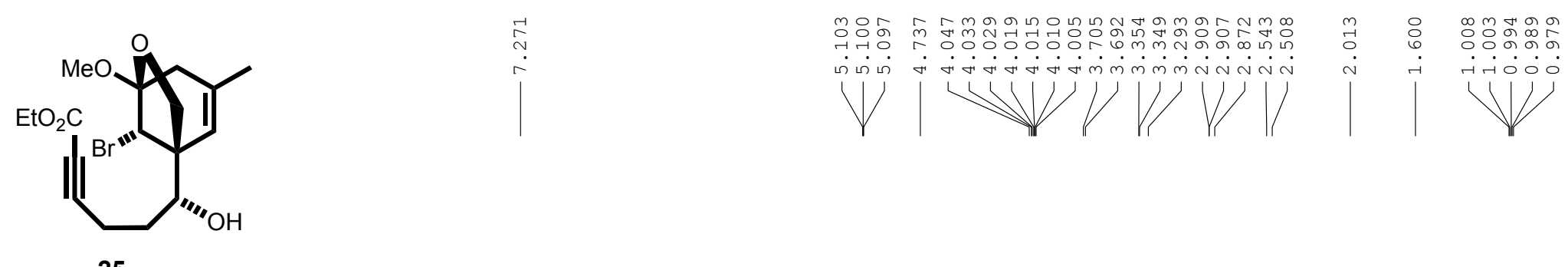

( $\left.\mathrm{C}_{6} \mathrm{D}_{6}, 500 \mathrm{MHz}\right)$

DY-2-81A

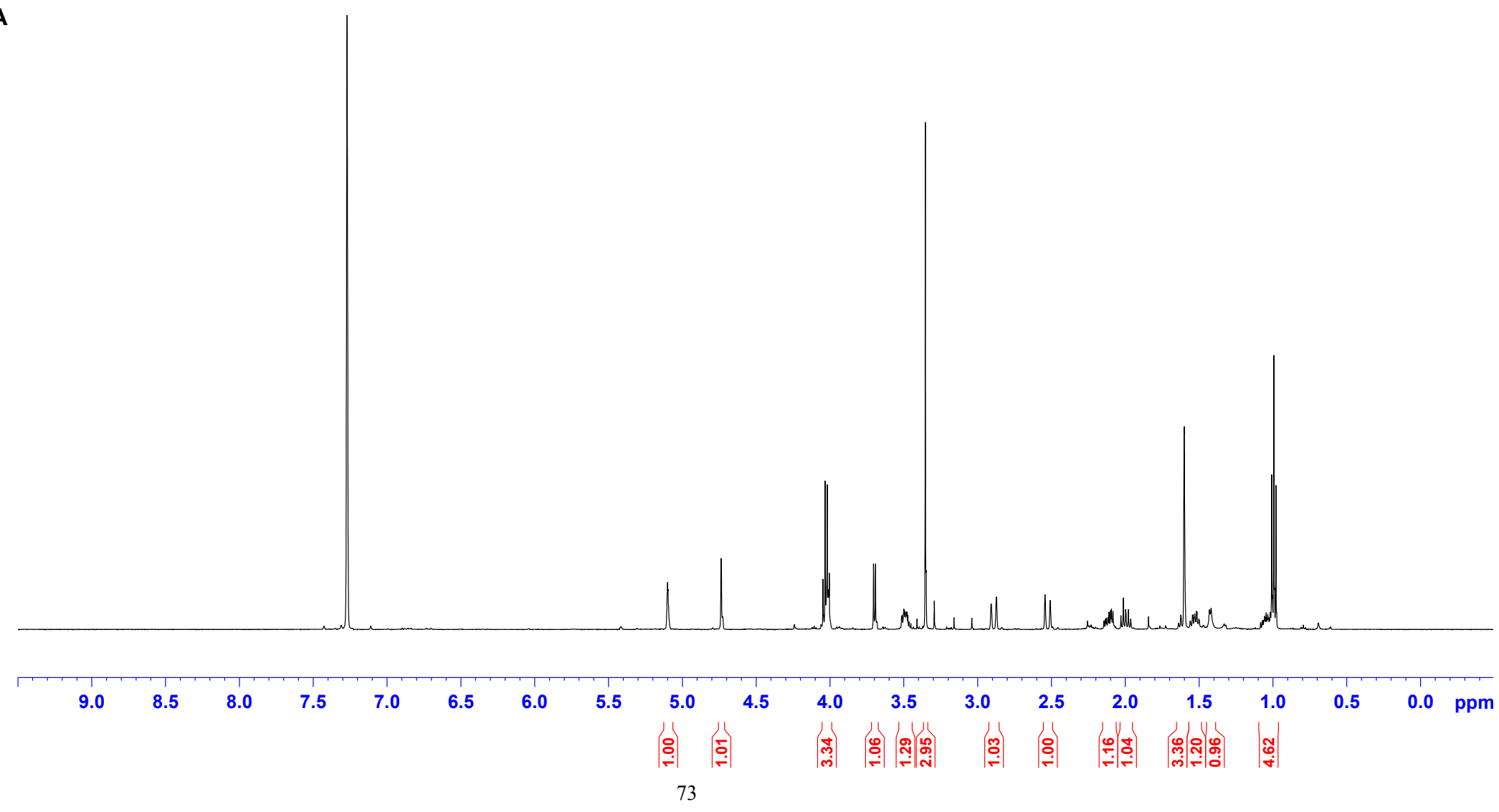




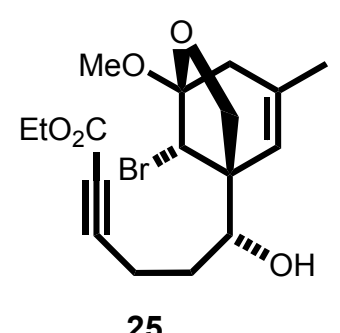

25

( $\left.\mathrm{C}_{6} \mathrm{D}_{6}, 500 \mathrm{MHz}\right)$

DY-2-81A

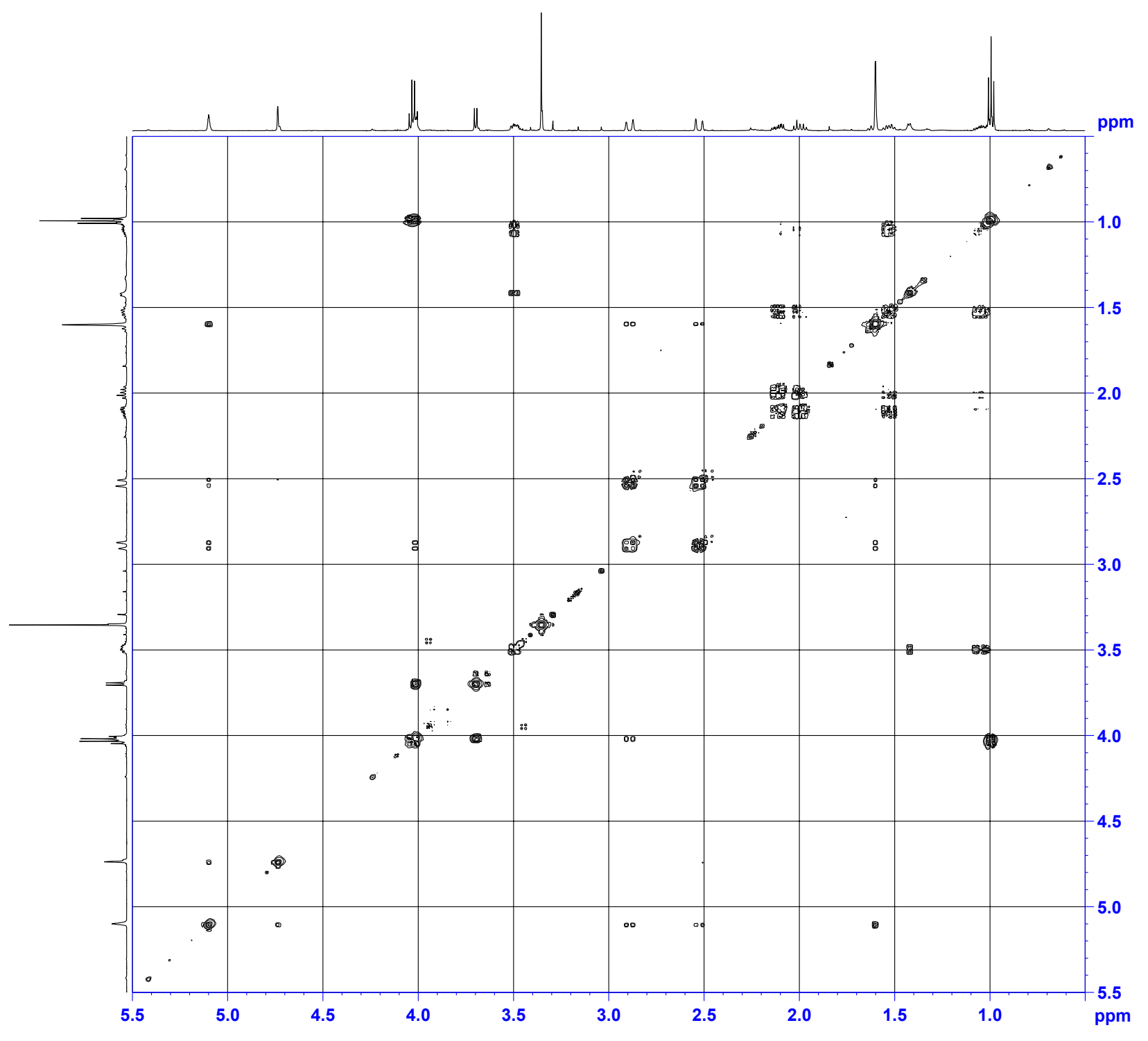

74 


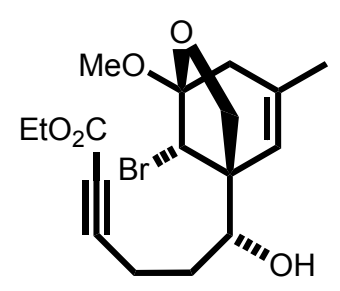

25

$\left(\mathrm{C}_{6} \mathrm{D}_{6}, 125 \mathrm{MHz}\right)$

DY-2-81A

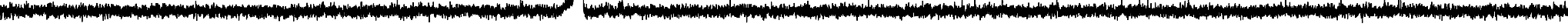

$\begin{array}{lllllllllll}200 & 190 & 180 & 170 & 160 & 150 & 140 & 130 & 120 & 11\end{array}$ 


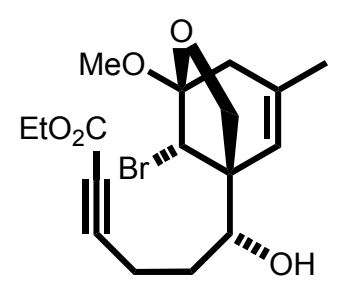

25

$\left(\mathrm{C}_{6} \mathrm{D}_{6}, 125 \mathrm{MHz}\right)$

DY-2-81A 


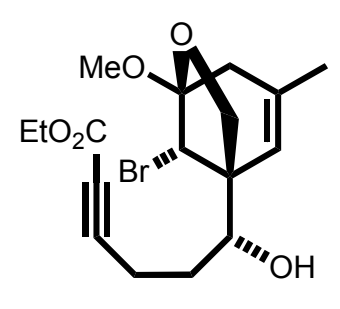

25

$\left(\mathrm{C}_{6} \mathrm{D}_{6},{ }^{1} \mathrm{H} 500 \mathrm{MHz}\right.$

${ }^{13} \mathrm{C} 125 \mathrm{MHz}$ )

DY-2-81A

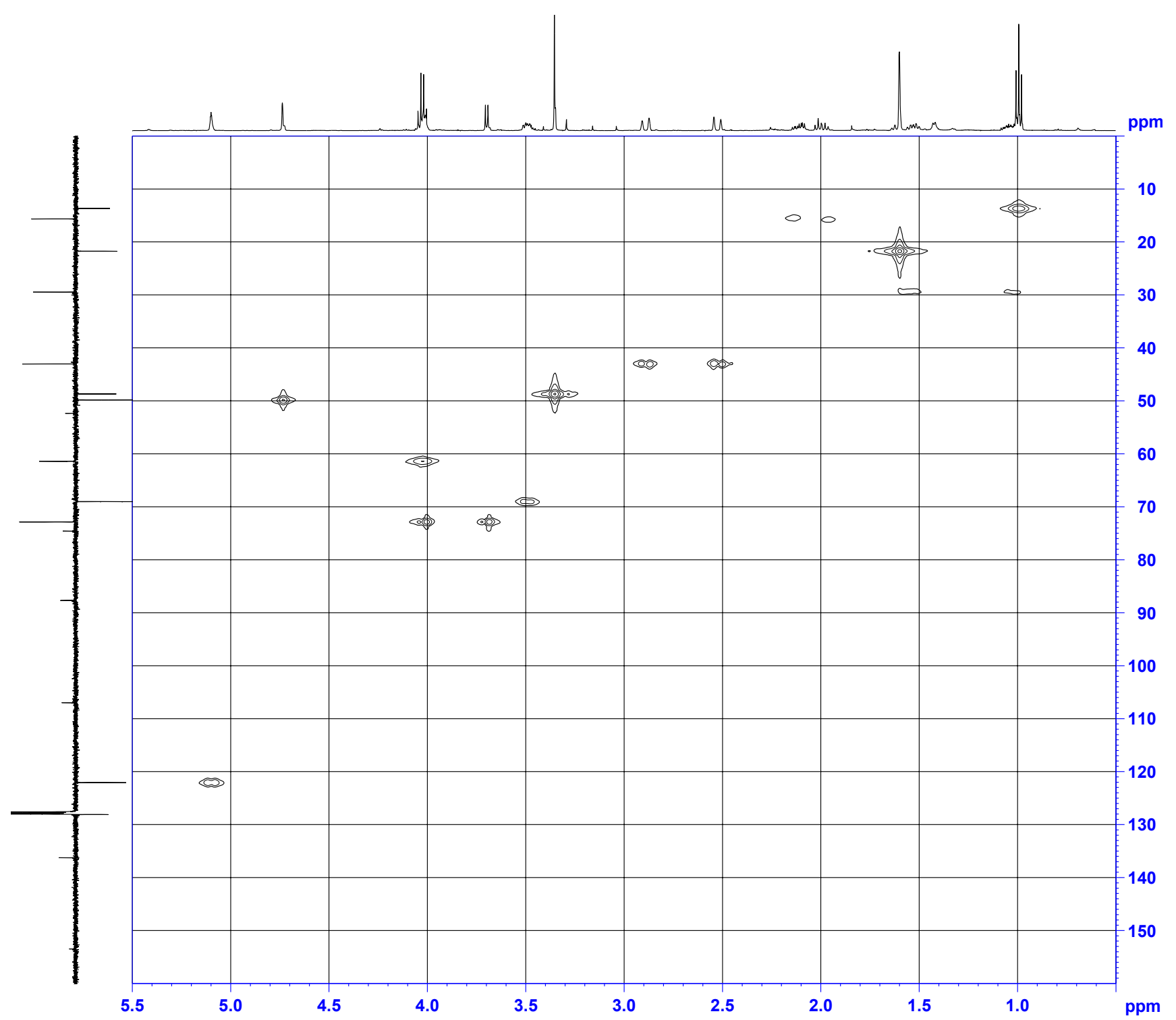

77 


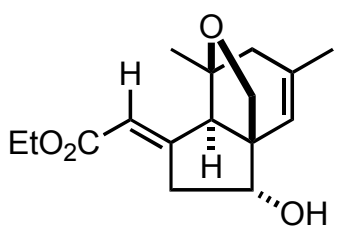

26

Perhydroindan 26. To a solution of $0.72 \mathrm{~g}(2.01 \mathrm{mmol})$ of 10 and $16.5 \mathrm{mg}(0.1 \mathrm{mmol})$ of azo-bis-isobutyronitrile in $200 \mathrm{~mL}$ of dry, degassed benzene at $105^{\circ} \mathrm{C}$ was added $1.17 \mathrm{~g}$ (4.02 mmol) of tri-n-butylstannane in $4 \mathrm{~mL}$ of dry, degassed benzene over a period of $1 \mathrm{~h}$. The mixture was warmed under reflux for $2 \mathrm{~h}$, and then concentrated in vacuo to give a pale yellow solid that was triturated with $2 \mathrm{~mL}$ of pentane. The crude solid was chromatographed over $30 \mathrm{~g}$ of silica gel (eluted with hexanes-ethyl acetate, 19:1) to afford $407 \mathrm{mg}$ (73\%) of 26 as a white crystalline solid: $\mathrm{mp} 131-132{ }^{\circ} \mathrm{C}$; IR (thin film) $3428,1712,1648 \mathrm{~cm}^{-1} ;{ }^{1} \mathrm{H}$ NMR $\left(500 \mathrm{MHz}, \mathrm{CDCl}_{3}\right) \delta 1.27\left(\mathrm{t}, J=7.2 \mathrm{~Hz}, 3 \mathrm{H}, \mathrm{CH}_{2} \mathrm{CH}_{3}\right), 1.54\left(\mathrm{~s}, 3 \mathrm{H}, \mathrm{CH}_{3}\right), 1.66\left(\mathrm{~s}, 3 \mathrm{H},=\mathrm{CCH}_{3}\right)$, $2.15(\mathrm{br} \mathrm{s}, 1 \mathrm{H}, \mathrm{OH}), 2.23,2.33\left(\mathrm{ABq}, J=17.8 \mathrm{~Hz}, 2 \mathrm{H}, \mathrm{CH}_{2}\right), 2.96(\mathrm{~s}, 1 \mathrm{H}, \mathrm{CH}), 3.10(\mathrm{dd}, J=$ 20.8, 2.2 Hz, $\left.1 \mathrm{H}, \underline{\mathrm{C}}_{2} \mathrm{CHOH}\right), 3.34\left(\mathrm{dm}, J=20.5 \mathrm{~Hz}, 1 \mathrm{H}, \mathrm{C}_{2} \mathrm{CHOH}\right), 3.44(\mathrm{~d}, J=7.5 \mathrm{~Hz}, 1 \mathrm{H}$, $\mathrm{CH}_{2} \mathrm{O}$ ), $3.84\left(\mathrm{~d}, J=7.5 \mathrm{~Hz}, 1 \mathrm{H}, \mathrm{CH}_{2} \mathrm{O}\right), 4.15\left(\mathrm{q}, J=7.2 \mathrm{~Hz}, 2 \mathrm{H}, \mathrm{C}_{2} \mathrm{CH}_{3}\right), 4.21$ (d, $J=5.0 \mathrm{~Hz}$, $1 \mathrm{H}, \mathrm{C} \underline{\mathrm{HOH}}) 5.98(\mathrm{~m}, 1 \mathrm{H},=\mathrm{CH}), 6.0\left(\mathrm{~m}, 1 \mathrm{H},=\mathrm{CHCCO}_{2}\right) ;{ }^{13} \mathrm{C} \mathrm{NMR}\left(125 \mathrm{MHz}, \mathrm{CDCl}_{3}\right) \delta 14.3$ (q), $22.0(\mathrm{q}), 22.4(\mathrm{q}), 43.4(\mathrm{t}), 50.2(\mathrm{t}), 58.0(\mathrm{~d}), 59.0(\mathrm{~s}), 59.9(\mathrm{t}), 71.0(\mathrm{~d}), 78.9(\mathrm{t}), 84.9(\mathrm{~s})$, 116.7 (d), 126.3 (d), 135.4 (s), 161.3 (s), 166.4 (s); exact mass calcd for $\mathrm{C}_{16} \mathrm{H}_{22} \mathrm{O}_{4}(\mathrm{M}+\mathrm{Na})^{+}$ $\mathrm{m} / \mathrm{z}$ 301.1416, found 301.1428. Anal. Calcd for $\mathrm{C}_{16} \mathrm{H}_{22} \mathrm{O}_{4}: \mathrm{C}, 69.04 ; \mathrm{H}, 7.97$. Found: $\mathrm{C}, 68.81$; $\mathrm{H}, 8.01$. 


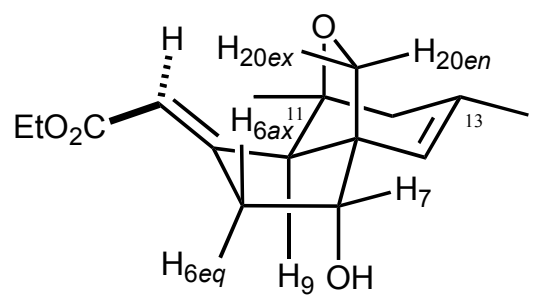

\begin{tabular}{|c|c|}
\hline Proton Irradiated & NOE \\
\hline $\mathrm{H}_{7}(4.21 \mathrm{ppm})$ & $\mathrm{H}_{20 \text { en }}(0.8 \%), \mathrm{H}_{20 \text { ex }}(1.3 \%), \mathrm{H}_{6 \text { ax }}(2.6 \%), \mathrm{H}_{6 \text { eq }}(1.2 \%), \mathrm{OH}(2.3 \%)$ \\
\hline $\mathrm{H}_{20 \text { en }}(3.84 \mathrm{ppm})$ & $\mathrm{H}_{7}(0.8 \%), \mathrm{H}_{20 \text { ex }}(17.0 \%)$ \\
\hline $\mathrm{H}_{20 \text { ex }}(3.44 \mathrm{ppm})$ & $\mathrm{H}_{7}(1.8 \%), \mathrm{H}_{20 \text { en }}(18.0 \%), \mathrm{H}_{6 \text { ax }}(3.6 \%)$ \\
\hline $\mathrm{H}_{6 \mathrm{ax}}(3.34 \mathrm{ppm})$ & $\mathrm{H}_{7}(3.4 \%), \mathrm{H}_{20 \text { ex }}(3.4 \%), \mathrm{H}_{6 \text { eq }}(10.9 \%)$ \\
\hline $\mathrm{H}_{6 \text { eq }}(3.10 \mathrm{ppm})$ & $\mathrm{H}_{7}(1.4 \%), \mathrm{H}_{6 a x}(11.8 \%), \mathrm{OH}(1.8 \%)$ \\
\hline $\mathrm{H}_{9}(2.96 \mathrm{ppm})$ & $\mathrm{H}_{12 \text { ax }}(1.7 \%), \mathrm{C}_{11} \mathrm{CH}_{3}(0.8 \%)$ \\
\hline $\mathrm{H}_{12 \text { ax }}(2.33 \mathrm{ppm})$ & $\mathrm{H}_{9}(2.5 \%), \mathrm{H}_{12 \text { eq }}(12 \%), \mathrm{C}_{13} \mathrm{CH}_{3}(1.9 \%), \mathrm{C}_{11} \mathrm{CH}_{3}(2.5 \%)$ \\
\hline $\mathrm{C}_{13} \mathrm{CH}_{3}(1.66 \mathrm{ppm})$ & $\mathrm{H}_{12 \text { ax }}(1.7 \%), \mathrm{H}_{12 \text { eq }}(1.8 \%)$ \\
\hline $\mathrm{C}_{11} \mathrm{CH}_{3}(1.54 \mathrm{ppm})$ & $\mathrm{H}_{9}(1.9 \%), \mathrm{H}_{12 \text { ax }}(4.0 \%), \mathrm{H}_{12 \text { eq }}(4.0 \%)$ \\
\hline
\end{tabular}



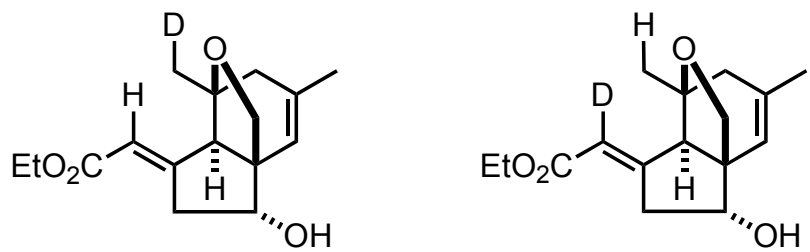

deuterated-26

deuterated Perhydroindan 26. To a solution of $209 \mathrm{mg}(0.58 \mathrm{mmol})$ of 10 and 4.8 $\mathrm{mg}(0.03 \mathrm{mmol})$ of azo-bis-isobutyronitrile in $60 \mathrm{~mL}$ of dry, degassed benzene at $105{ }^{\circ} \mathrm{C}$ was added $341 \mathrm{mg}(1.17 \mathrm{mmol})$ of tri- $n$-butyltin deuteride in $2 \mathrm{~mL}$ of dry, degassed benzene via pipet. The mixture was warmed under reflux for $4 \mathrm{~h}$, and then concentrated in vacuo to give a pale yellow solid that was triturated with $2 \mathrm{~mL}$ of pentane. The crude solid was chromatographed over $50 \mathrm{~g}$ of silica gel (eluted with hexanes-ethyl acetate, 19:1 $\rightarrow$ 9:1) to afford $126 \mathrm{mg}(73 \%)$ of deuterated-26 as a white crystalline solid: $\mathrm{mp} 130-131^{\circ} \mathrm{C} ;{ }^{2} \mathrm{H}$ NMR $\left(76 \mathrm{MHz} \mathrm{CHCl}_{3}\right) \delta 1.57$ (s, 1D, $\left.\mathrm{CH}_{2} \mathrm{D}\right), 6.06$ (s, 1D, =CDCCO ${ }_{2}$. Anal. Calcd for $\mathrm{C}_{16} \mathrm{H}_{21} \mathrm{DO}_{4}: \mathrm{C}$, 69.04; H+D as $H, 7.94$. Found: $C, 68.81 ; H, 8.00$. 


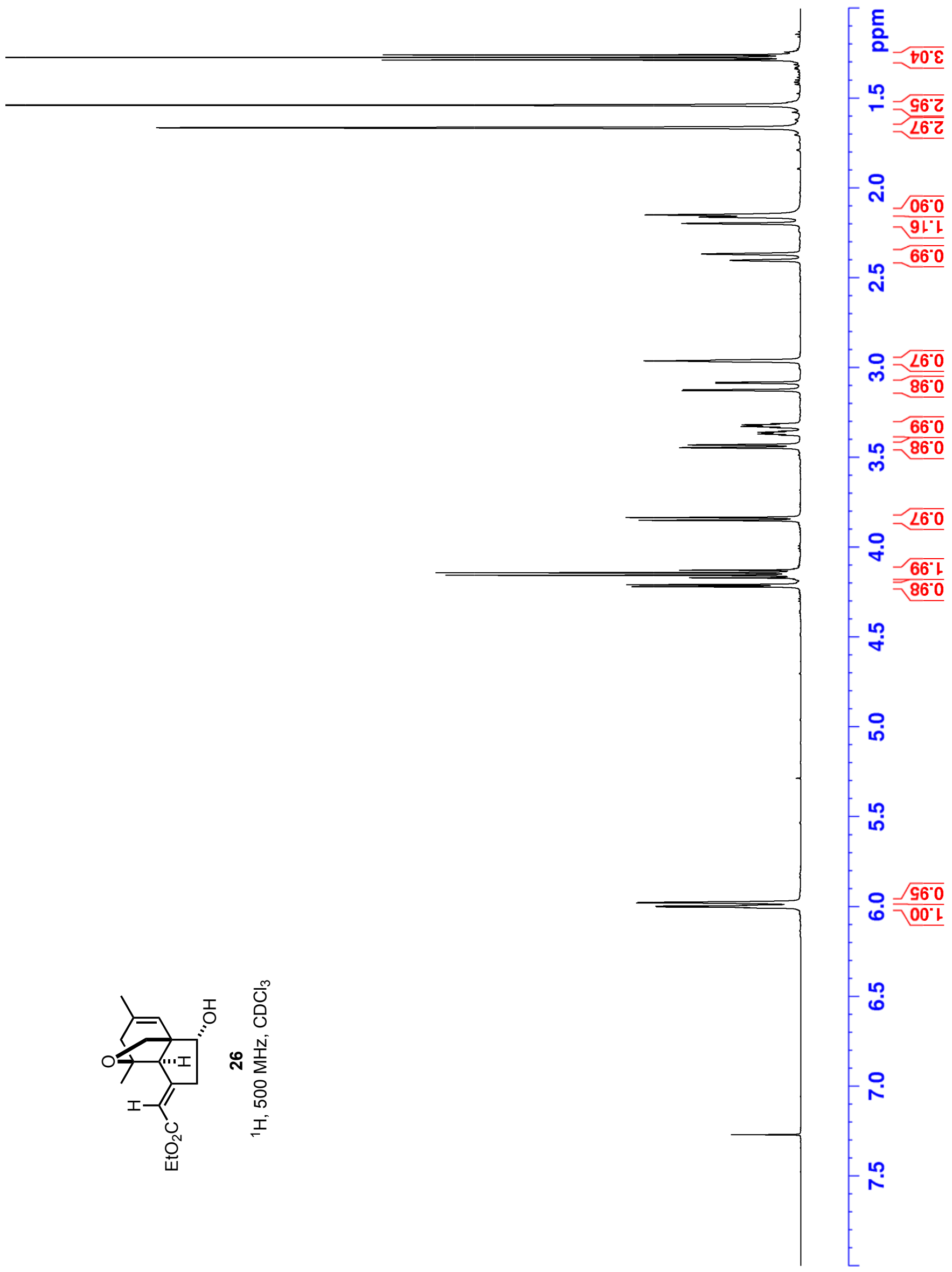




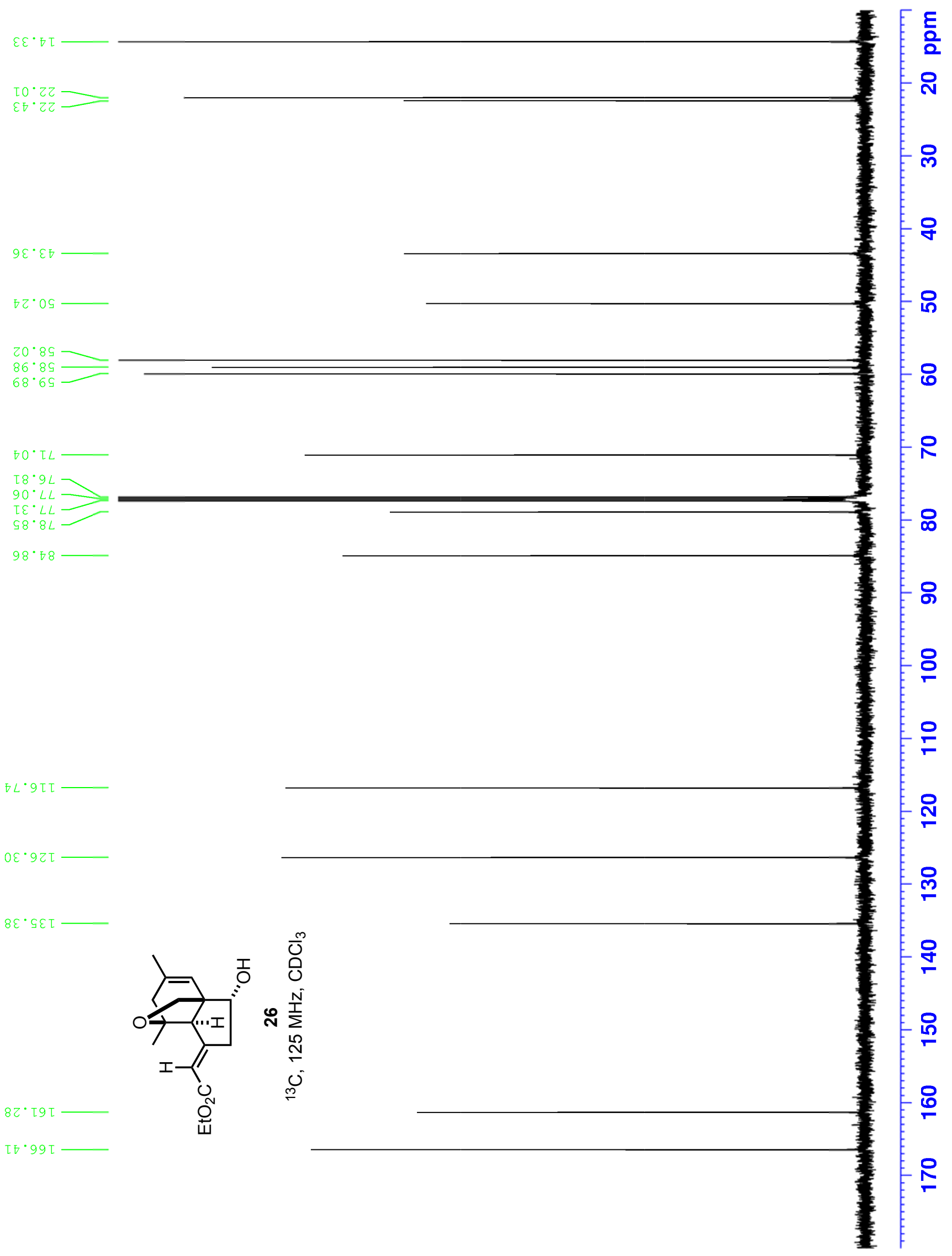




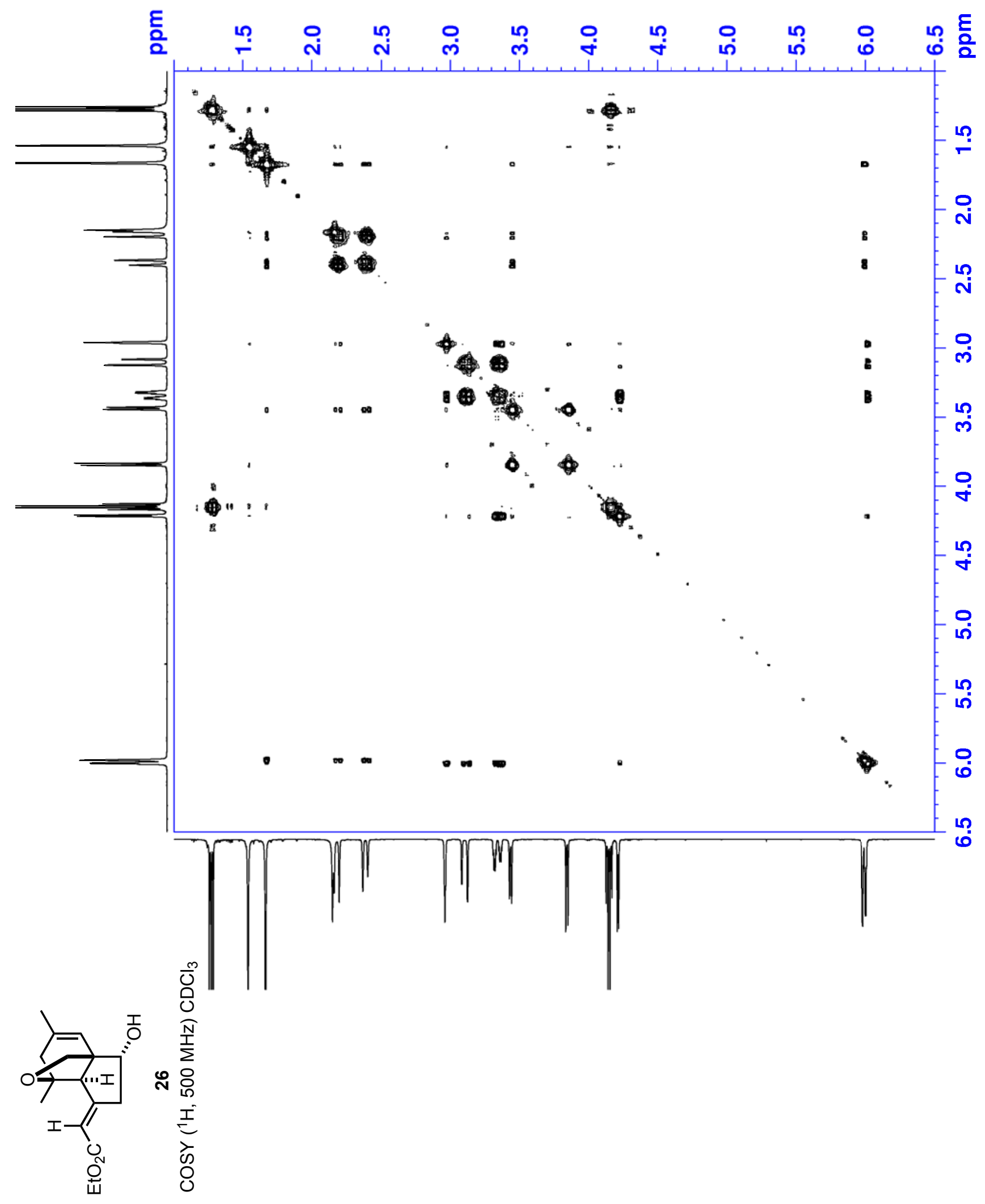




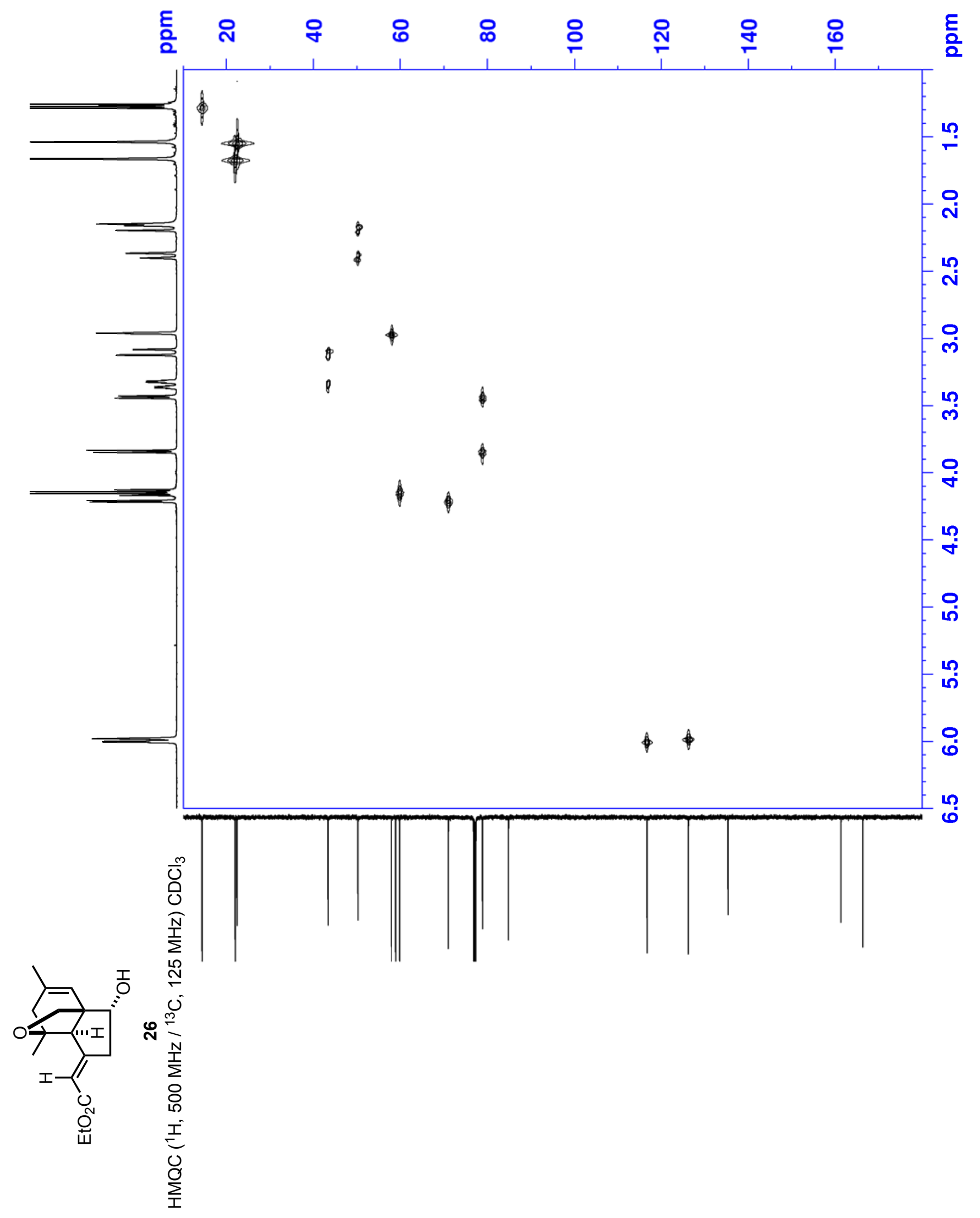




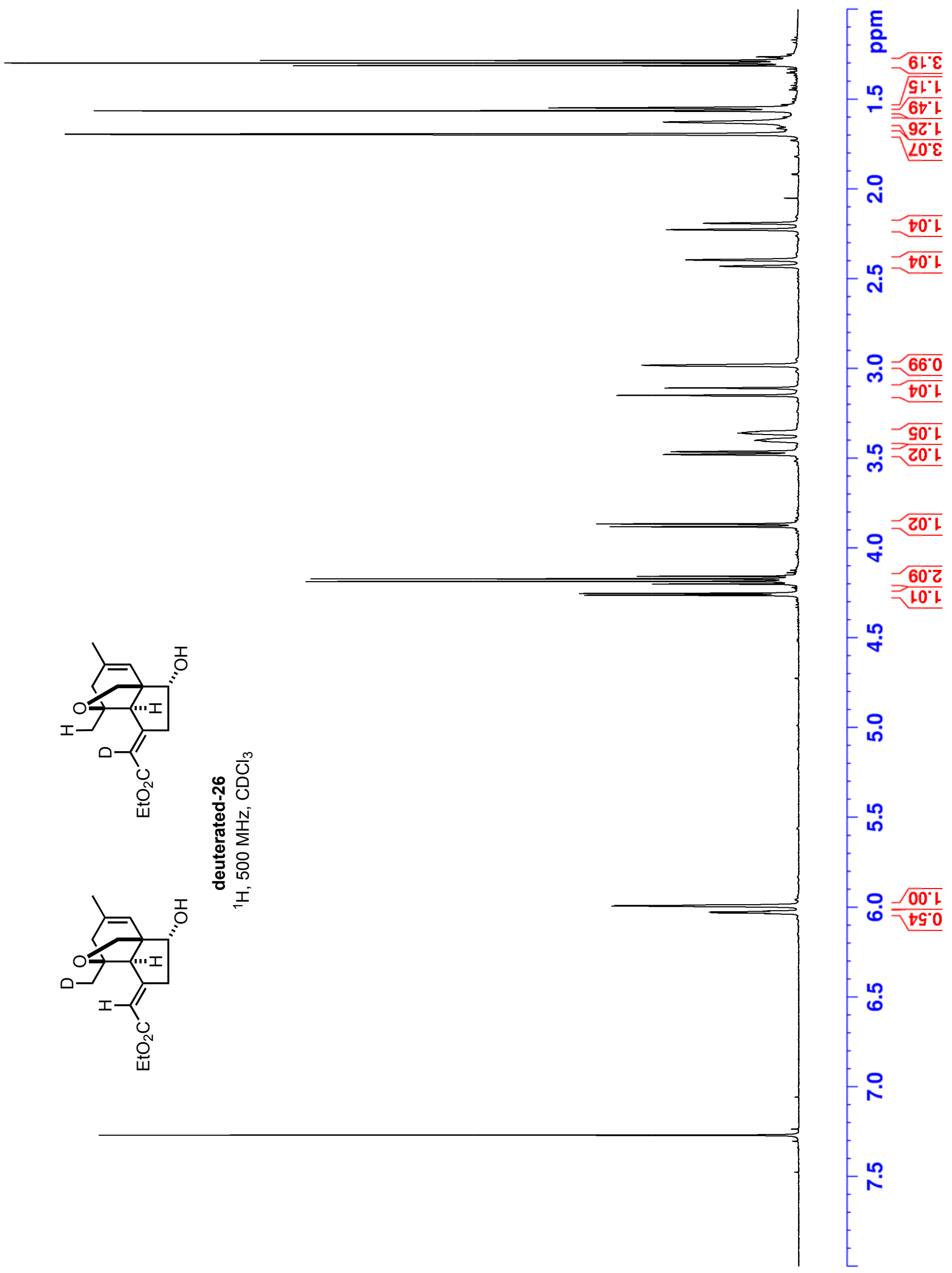




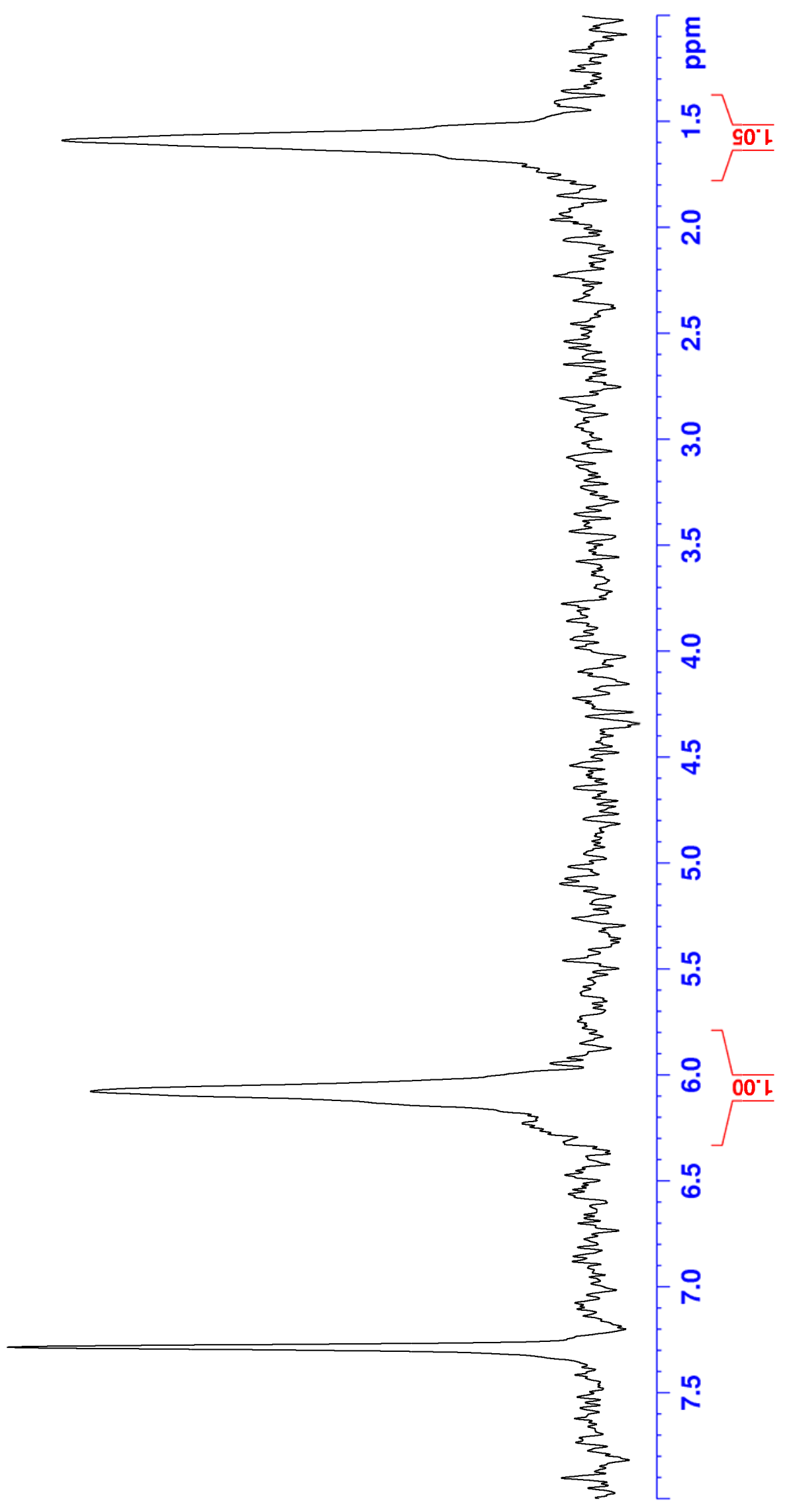




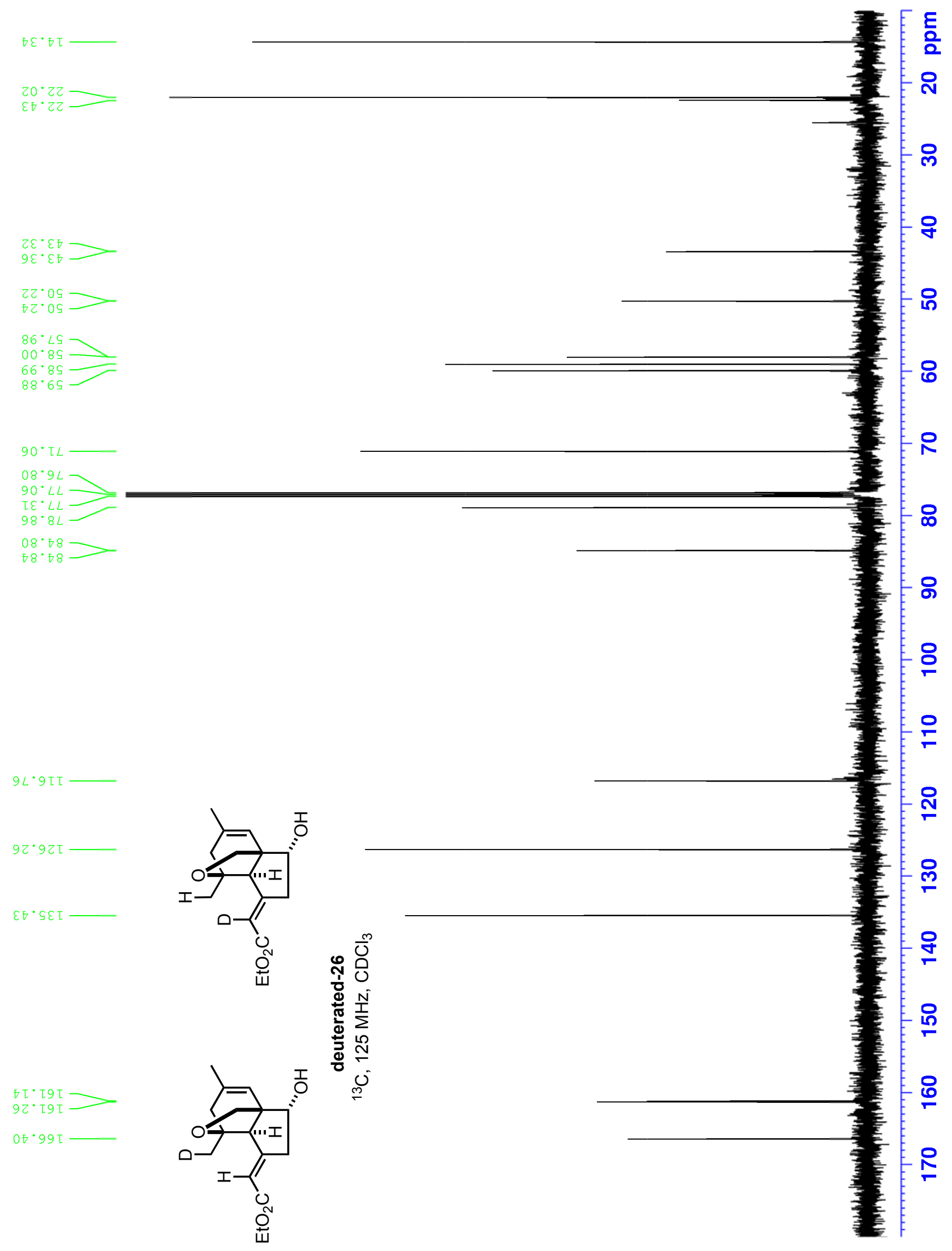




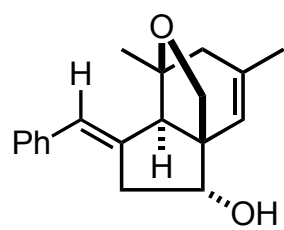

27

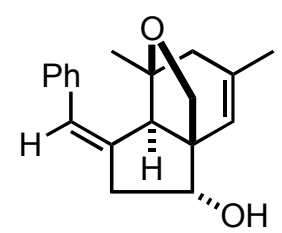

28

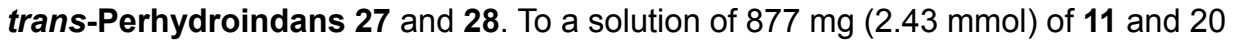
$\mathrm{mg}(0.12 \mathrm{mmol})$ of azo-bis-isobutyronitrile in $240 \mathrm{~mL}$ of dry, degassed benzene at $110^{\circ} \mathrm{C}$ was

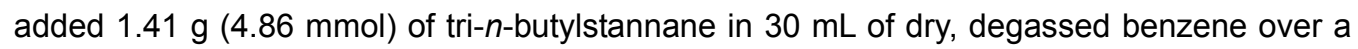
period of $45 \mathrm{~min}$. The mixture was warmed under reflux for $15 \mathrm{~min}$, and then concentrated in vacuo. The residual crude oil was chromatographed over $50 \mathrm{~g}$ of silica gel (eluted with hexanes-ethyl acetate, $20: 1)$ to afford $673 \mathrm{mg}(98 \%)$ of a $1: 1(E: Z)$ mixture of 27 and $\mathbf{2 8}$, respectively. The less polar $E$ isomer (27) was isolated as a pale yellow oil: IR (thin film) 3402 $\mathrm{cm}^{-1} ;{ }^{1} \mathrm{H}$ NMR $\left(500 \mathrm{MHz}, \mathrm{CDCl}_{3}\right) \delta 1.62\left(\mathrm{~s}, 3 \mathrm{H}, \mathrm{CH}_{3}\right), 1.71\left(\mathrm{~s}, 3 \mathrm{H},=\mathrm{CCH}_{3}\right), 2.08(\mathrm{br} \mathrm{s}, 1 \mathrm{H}, \mathrm{OH})$, 2.28 and $2.37\left(\mathrm{ABq}, J=17.5 \mathrm{~Hz}, 2 \mathrm{H}, \mathrm{CH}_{2}\right), 2.72\left(\mathrm{dd}, J=18.7,1.8 \mathrm{~Hz}, 1 \mathrm{H}, \mathrm{C}_{2} \mathrm{CHOH}\right), 3.03$ (s, $1 \mathrm{H}, \mathrm{CH}), 3.23-3.29\left(\mathrm{~m}, 1 \mathrm{H}, \mathrm{CH}_{2} \mathrm{CHOH}\right), 3.58\left(\mathrm{~d}, J=7.5 \mathrm{~Hz}, 1 \mathrm{H}, \mathrm{CH}_{2} \mathrm{O}\right), 3.89(\mathrm{~d}, J=8.0$ $\left.\mathrm{Hz}, 1 \mathrm{H}, \mathrm{CH}_{2} \mathrm{O}\right), 4.23(\mathrm{~d}, J=5.0 \mathrm{~Hz}, 1 \mathrm{H}, \underline{\mathrm{CH} O H}), 6.00(\mathrm{~m}, 1 \mathrm{H},=\mathrm{CH}), 6.60(\mathrm{~m}, 1 \mathrm{H},=\mathrm{C} \underline{\mathrm{H} A r})$, $7.22\left(\mathrm{~m}, 1 \mathrm{H}, \mathrm{ArH}_{p}\right), 7.30-7.37\left(\mathrm{~m}, 4 \mathrm{H}, \mathrm{ArH}_{o}, \mathrm{ArH}_{m}\right) ;{ }^{13} \mathrm{C} \mathrm{NMR}\left(125 \mathrm{MHz}, \mathrm{CDCl}_{3}\right) \delta 22.1$ (q), $22.6(q), 41.8(t), 50.3(t), 57.9(d), 59.2(s), 71.8(d), 79.2(t), 85.3(s), 126.4(d), 126.5(d)$, 127.2 (d), 128.28 (d), 128.33 (d), 135.5 (s), 138.1 (s), 139.8 (s); exact mass calcd for $\mathrm{C}_{19} \mathrm{H}_{22} \mathrm{O}_{2}(\mathrm{M}+\mathrm{Na})^{+} \mathrm{m} / \mathrm{z} 305.1517$, found $\mathrm{m} / \mathrm{z} 305.1515$. 


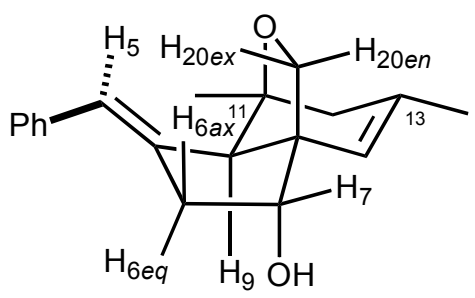

\begin{tabular}{|c|c|}
\hline$\underline{\text { Proton Irradiated }}$ & $\underline{\mathrm{NOE}}$ \\
\hline $\mathrm{H}_{5}(6.60 \mathrm{ppm})$ & $\operatorname{Ar~H}(2.8 \%), \mathrm{H}_{9}(1.2 \%), \mathrm{H}_{6 \text { eq }}(0.5 \%), \mathrm{C}_{11} \mathrm{CH}_{3}(4.3 \%)$ \\
\hline $\mathrm{H}_{14}(6.00 \mathrm{ppm})$ & $\mathrm{H}_{7}(0.9 \%), \mathrm{H}_{20 \text { ex }}(0.8 \%), \mathrm{H}_{9}(0.5 \%), \mathrm{OH}(1.3 \%), \mathrm{C}_{11} \mathrm{CH}_{3}(2.0 \%)$ \\
\hline $\mathrm{H}_{7}(4.23 \mathrm{ppm})$ & $\mathrm{H}_{14}(1.0 \%), \mathrm{H}_{20 \text { en }}(0.8 \%), \mathrm{H}_{20 \text { ex }}(1.4 \%), \mathrm{H}_{6 \text { ax }}(2.6 \%), \mathrm{H}_{6 \text { eq }}(1.2 \%)$, \\
\hline & $\mathrm{OH}(1.9 \%)$ \\
\hline $\mathrm{H}_{20 \text { en }}(3.89 \mathrm{ppm})$ & $\mathrm{H}_{14}(1.1 \%), \mathrm{H}_{7}(0.8 \%), \mathrm{H}_{20 \text { ex }}(15.7 \%)$ \\
\hline $\mathrm{H}_{20 \text { ex }}(3.58 \mathrm{ppm})$ & $\mathrm{H}_{7}(1.7 \%), \mathrm{H}_{20 \text { en }}(17.2 \%), \mathrm{H}_{6 \text { ax }}(4.4 \%)$ \\
\hline $\mathrm{H}_{6 \mathrm{ax}}(3.26 \mathrm{ppm})$ & $\operatorname{Ar~H}(3.7 \%), \mathrm{H}_{7}(3.4 \%), \mathrm{H}_{20 \text { ex }}(4.8 \%), \mathrm{H}_{6 \text { eq }}(15.7 \%)$ \\
\hline $\mathrm{H}_{9}(3.03 \mathrm{ppm})$ & $\mathrm{H}_{5}(1.1 \%), \mathrm{H}_{5}(0.5 \%), \mathrm{H}_{12 \text { ax }}(1.7 \%), \mathrm{OH}(0.7 \%), \mathrm{C}_{11} \mathrm{CH}_{3}(0.8 \%)$ \\
\hline $\mathrm{H}_{6 \text { eq }}(3.03 \mathrm{ppm})$ & $\mathrm{H}_{7}(1.4 \%), \mathrm{H}_{6 a x}(14.9 \%), \mathrm{H}_{9}(0.5 \%), \mathrm{OH}(1.6 \%)$ \\
\hline $\mathrm{H}_{12 a x}(2.37 \mathrm{ppm})$ & $\mathrm{H}_{9}(2.5 \%), \mathrm{H}_{12 \text { eq }}(9.0 \%), \mathrm{C}_{13} \mathrm{CH}_{3}(1.8 \%), \mathrm{C}_{11} \mathrm{CH}_{3}(2.5 \%)$ \\
\hline $\mathrm{H}_{12 \text { eq }}(2.28 \mathrm{ppm})$ & $\mathrm{H}_{12 \text { eq }}(11.8 \%), \mathrm{C}_{13} \mathrm{CH}_{3}(1.7 \%), \mathrm{C}_{11} \mathrm{CH}_{3}(2.0 \%)$ \\
\hline $\mathrm{C}_{13} \mathrm{CH}_{3}(1.71 \mathrm{ppm})$ & $\mathrm{H}_{14}(3.2 \%), \mathrm{H}_{12 \text { ax }}(2.1 \%), \mathrm{H}_{12 \text { eq }}(2.2 \%)$ \\
\hline $\mathrm{C}_{11} \mathrm{CH}_{3}(1.62 \mathrm{ppm})$ & $\mathrm{H}_{5}(9.0 \%), \mathrm{H}_{9}(2.1 \%), \mathrm{H}_{12 \text { ax }}(4.2 \%), \mathrm{H}_{12 \text { eq }}(3.7 \%)$ \\
\hline
\end{tabular}


The more polar $Z$ isomer (28) was isolated as a pale yellow oil: IR (thin film) $3384 \mathrm{~cm}^{-1} ;{ }^{1} \mathrm{H}$ $\operatorname{NMR}\left(500 \mathrm{MHz}, \mathrm{CDCl}_{3}\right) \delta 0.77\left(\mathrm{~s}, 3 \mathrm{H}, \mathrm{CH}_{3}\right), 1.69\left(\mathrm{~s}, 3 \mathrm{H},=\mathrm{CCH}_{3}\right), 2.04(\mathrm{br} \mathrm{s}, 1 \mathrm{H}, \mathrm{OH}), 2.16$ and $2.26\left(\mathrm{ABq}, J=17.8 \mathrm{~Hz}, 2 \mathrm{H}, \mathrm{CH}_{2}\right), 2.62\left(\mathrm{dd}, J=18.0,1.0 \mathrm{~Hz}, 1 \mathrm{H}, \mathrm{C}_{2} \mathrm{CHOH}\right), 3.31(\mathrm{~m}$, $\left.1 \mathrm{H}, \underline{\mathrm{C}}_{2} \mathrm{CHOH}\right), 3.56(\mathrm{t}, J=3.0 \mathrm{~Hz}, 1 \mathrm{H}, \mathrm{CH}), 3.61\left(\mathrm{~d}, J=7.5 \mathrm{~Hz}, 1 \mathrm{H}, \mathrm{CH}_{2} \mathrm{O}\right), 3.88(\mathrm{~d}, J=7.5$ $\left.\mathrm{Hz}, 1 \mathrm{H}, \mathrm{CH}_{2} \mathrm{O}\right), 4.16(\mathrm{~d}, J=4.5 \mathrm{~Hz}, 1 \mathrm{H}, \underline{\mathrm{C}} \underline{\mathrm{OH}}), 6.09(\mathrm{~m}, 1 \mathrm{H},=\mathrm{CH}), 6.64(\mathrm{~m}, 1 \mathrm{H},=\mathrm{C} \underline{\mathrm{H} A r})$, 7.18-7.20 (m, 1H, $\left.\mathrm{ArH}_{p}\right), 7.27-7.31\left(\mathrm{~m}, 4 \mathrm{H}, \mathrm{ArH}_{o}, \mathrm{ArH}_{m}\right) ;{ }^{13} \mathrm{C} \mathrm{NMR}\left(125 \mathrm{MHz}, \mathrm{CDCl}_{3}\right) \delta 22.1$ (q), $23.6(\mathrm{q}), 44.8(\mathrm{t}), 50.6(\mathrm{t}), 55.0(\mathrm{~d}), 61.5(\mathrm{~s}), 71.5(\mathrm{~d}), 79.2(\mathrm{t}), 86.8(\mathrm{~s}), 126.4(\mathrm{~d}), 127.2(\mathrm{~d})$, 127.8 (d), 128.2 (d), 128.3 (d), 135.8 (s), 139.6 (s), 139.7 (s); exact mass calcd for $\mathrm{C}_{19} \mathrm{H}_{22} \mathrm{O}_{2}$ $(\mathrm{M}+\mathrm{Na})^{+} \mathrm{m} / \mathrm{z}$ 305.1517, found $\mathrm{m} / \mathrm{z} 305.1517$. 

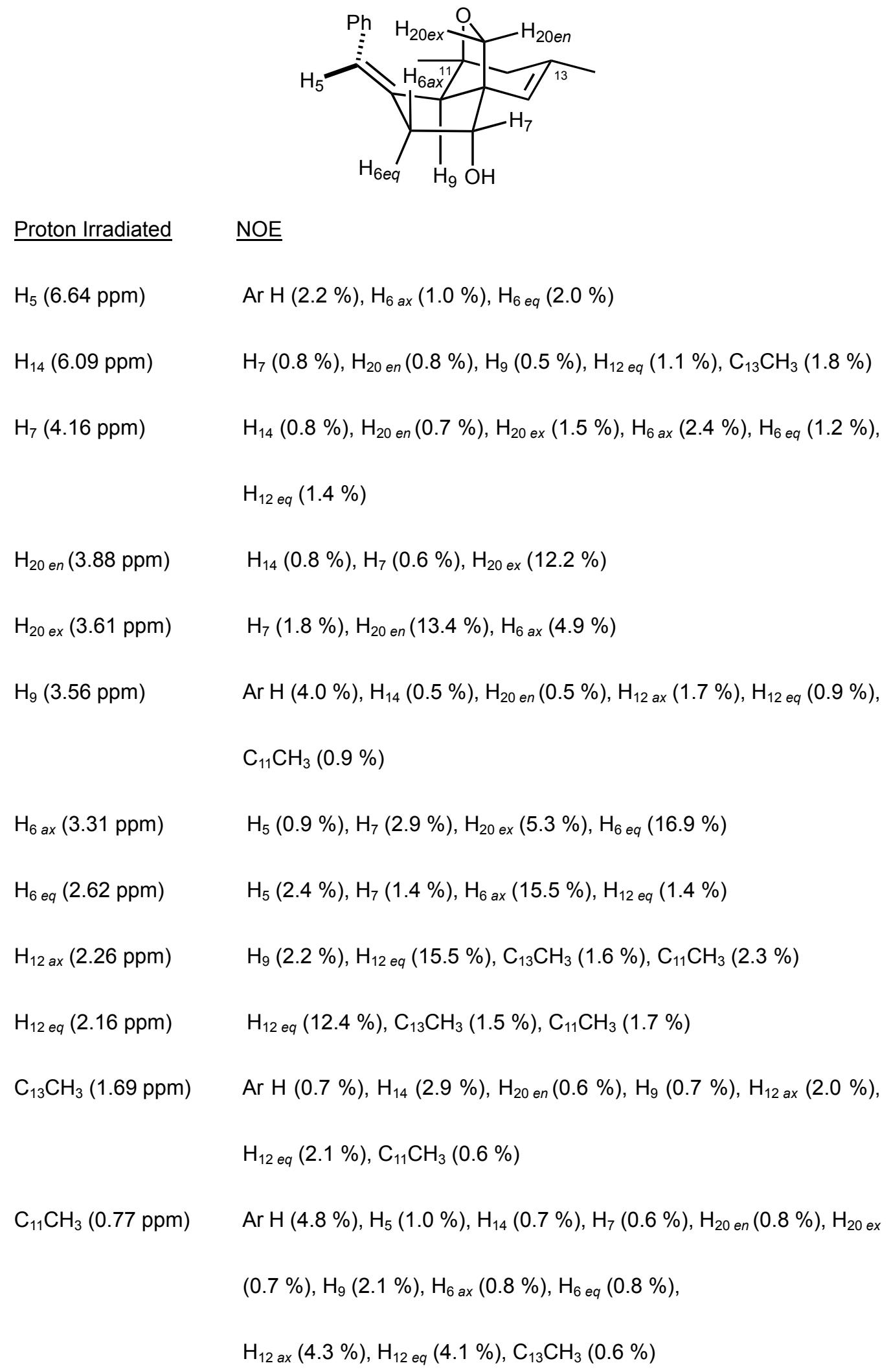


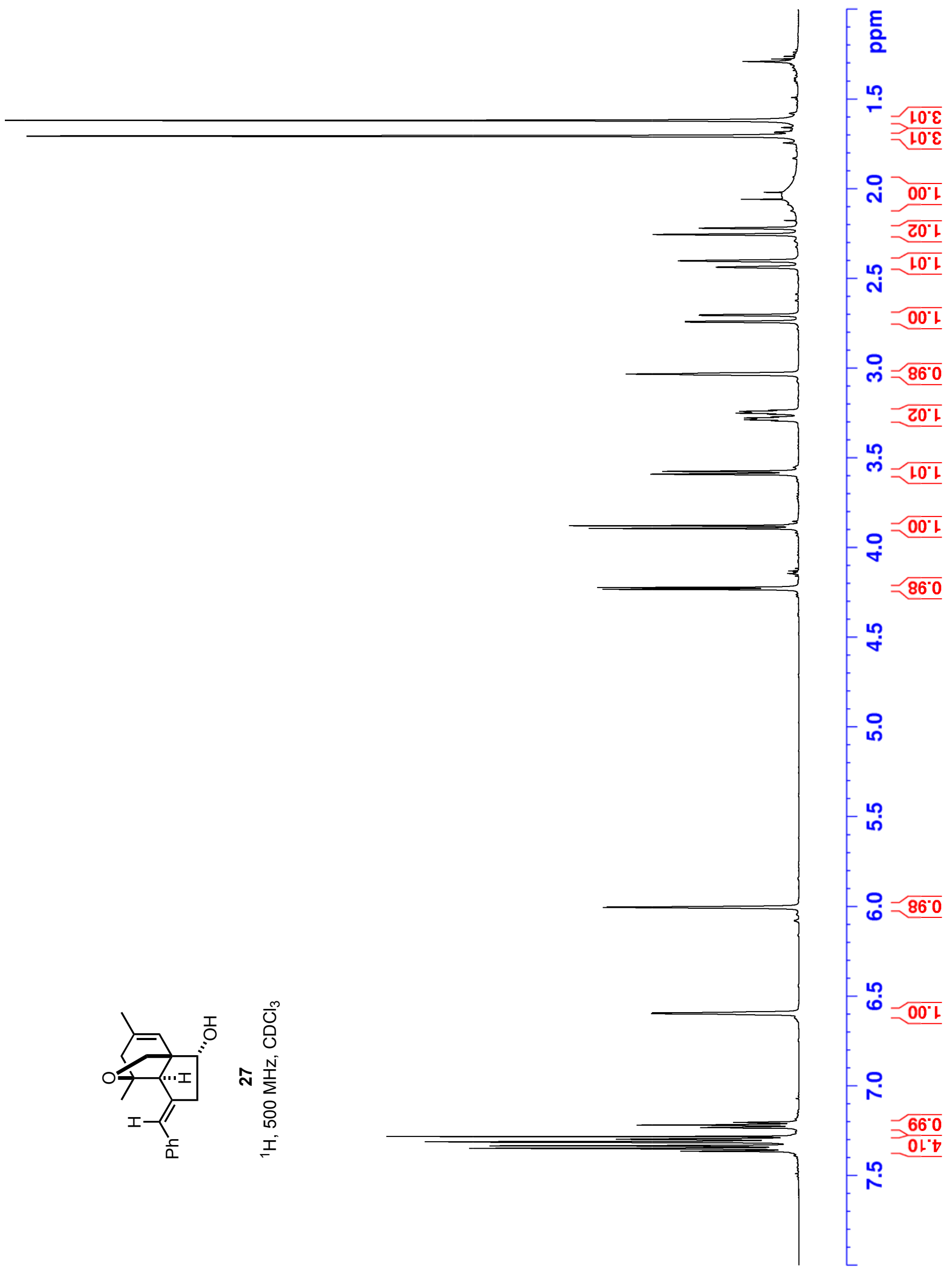




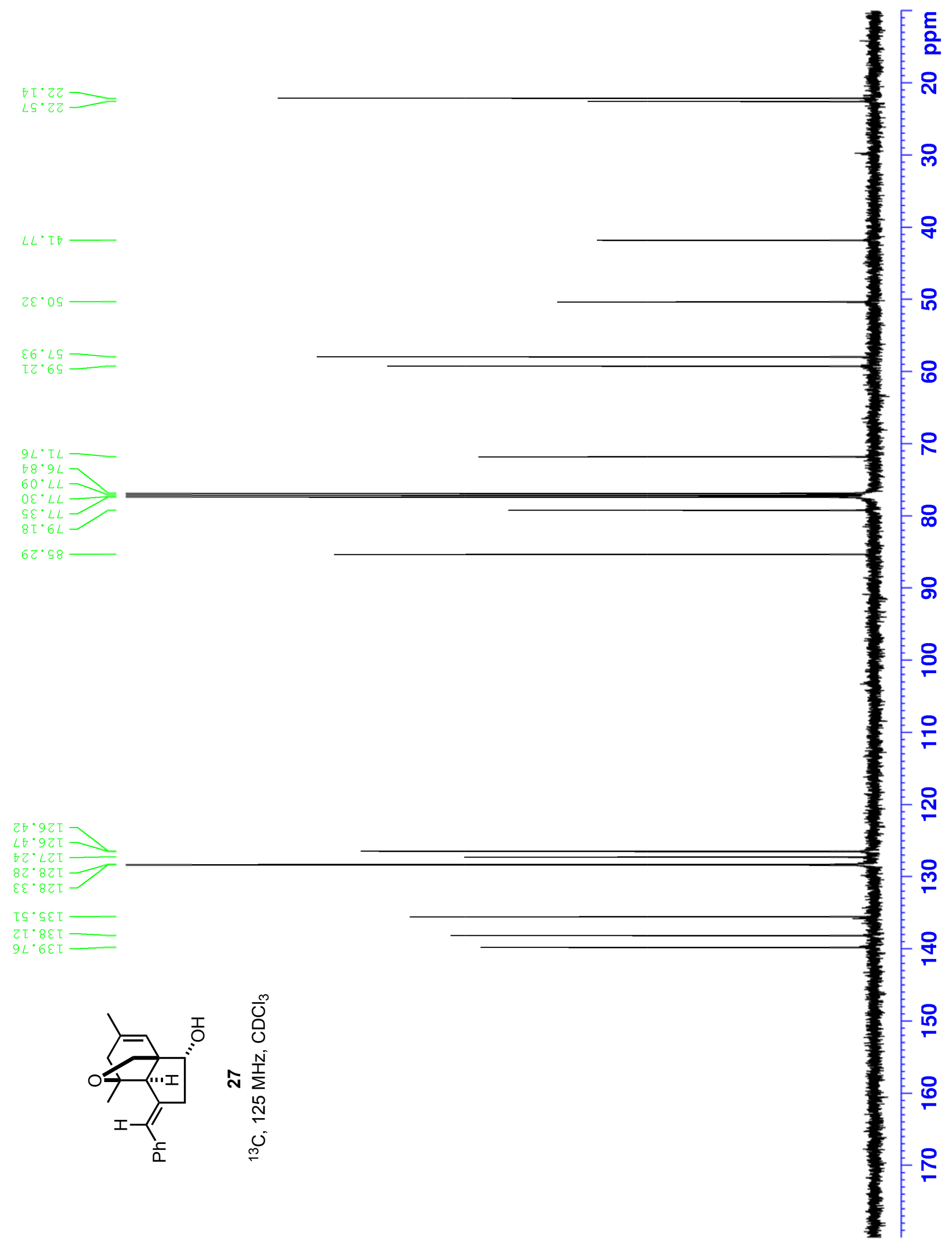




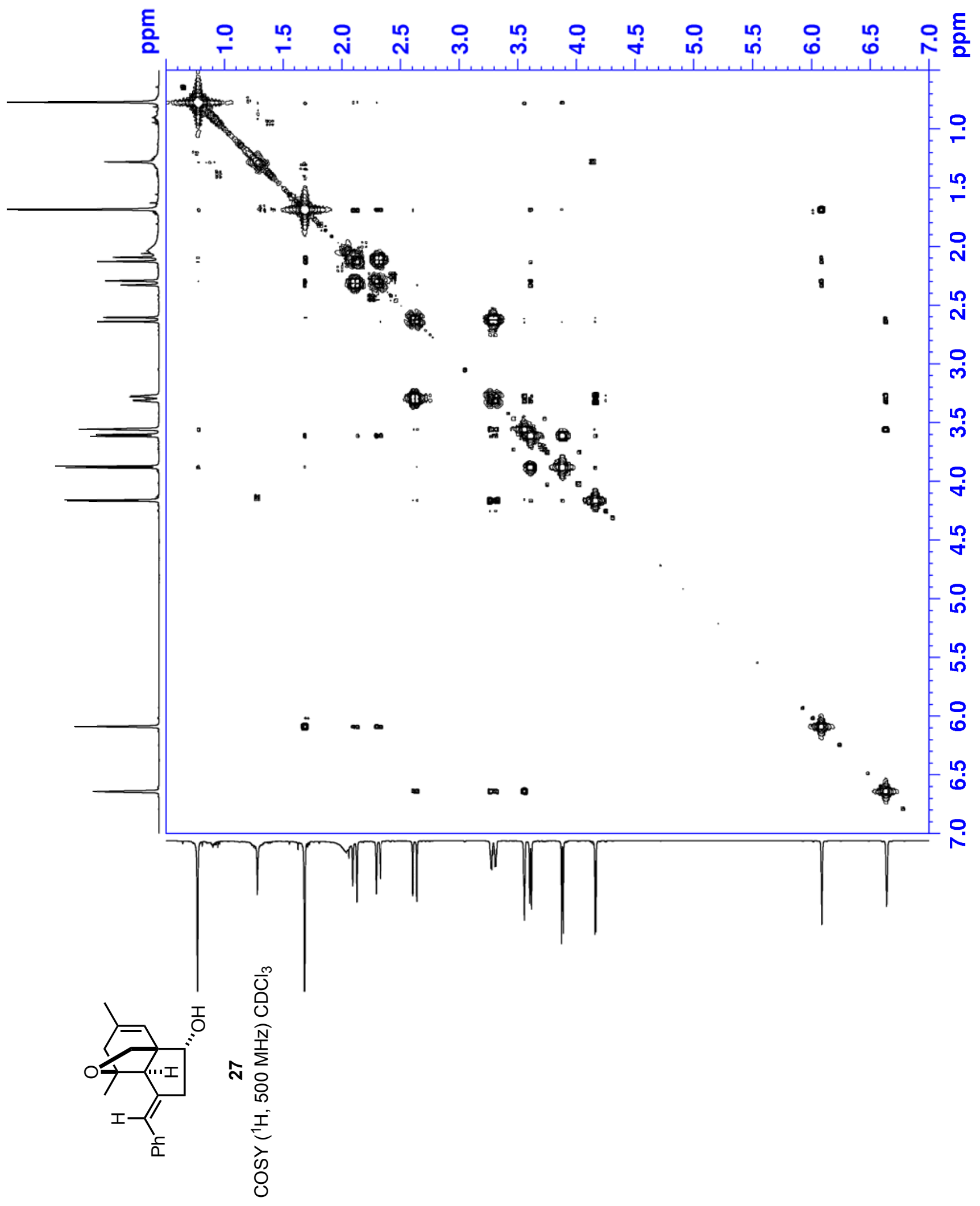




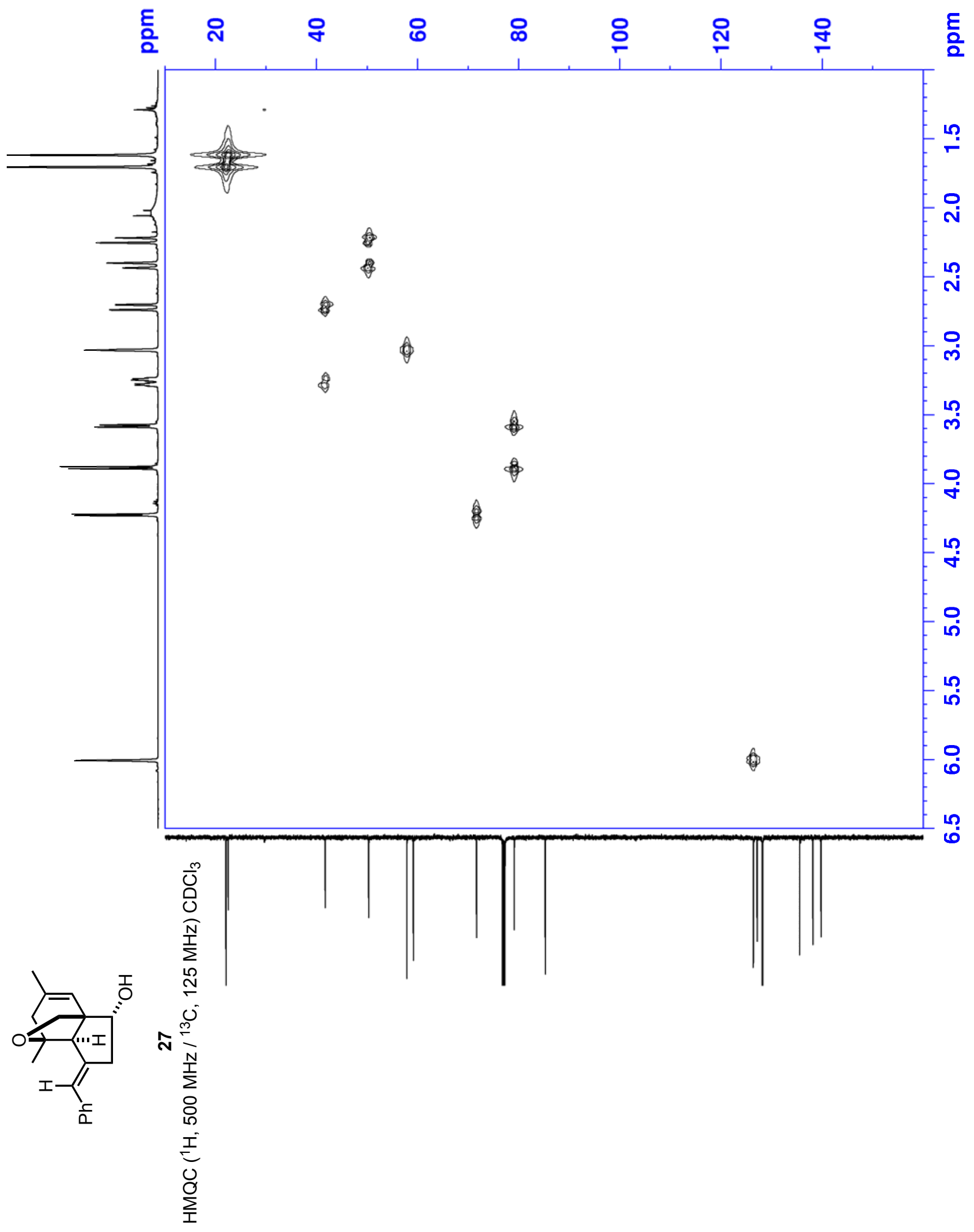




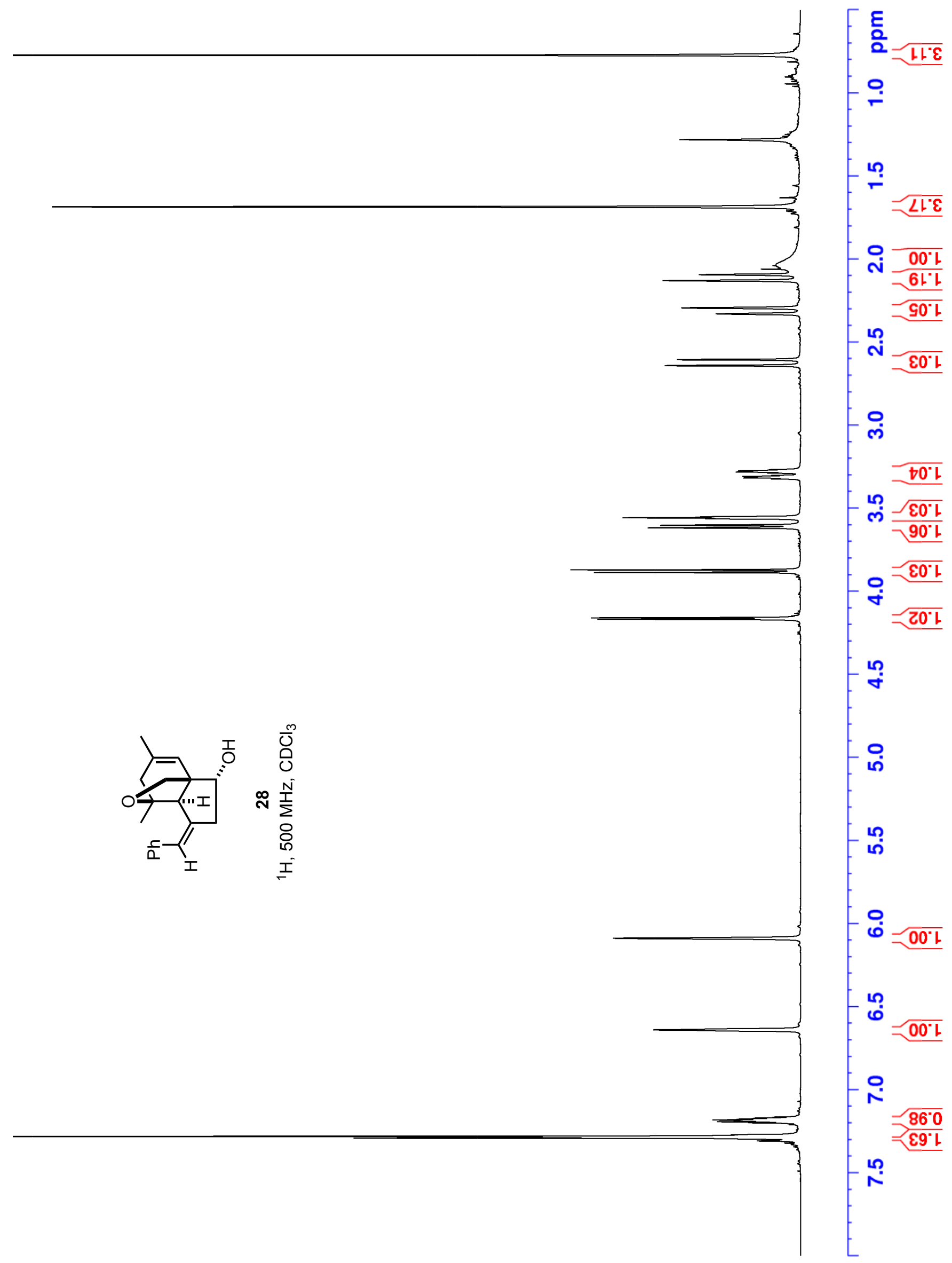




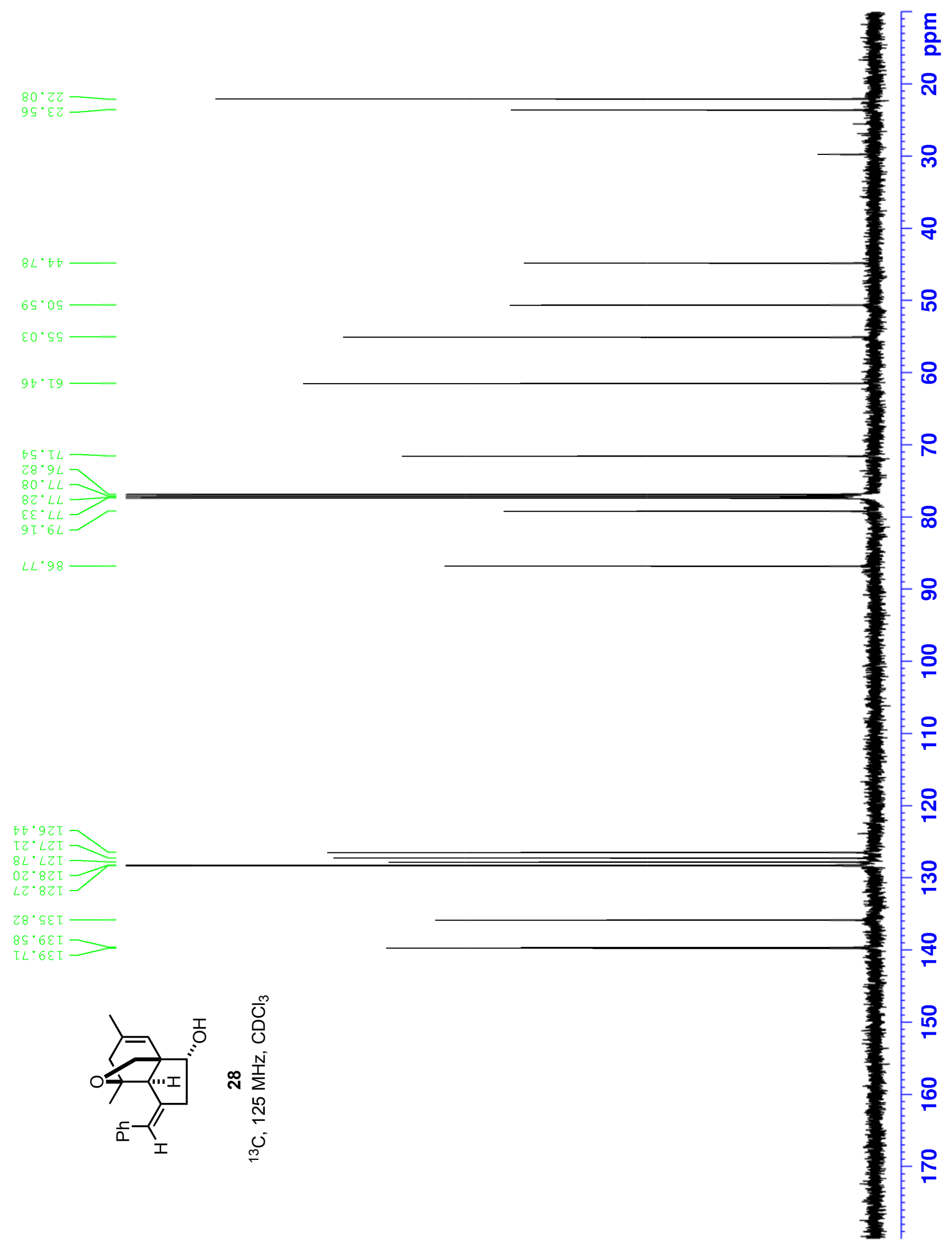




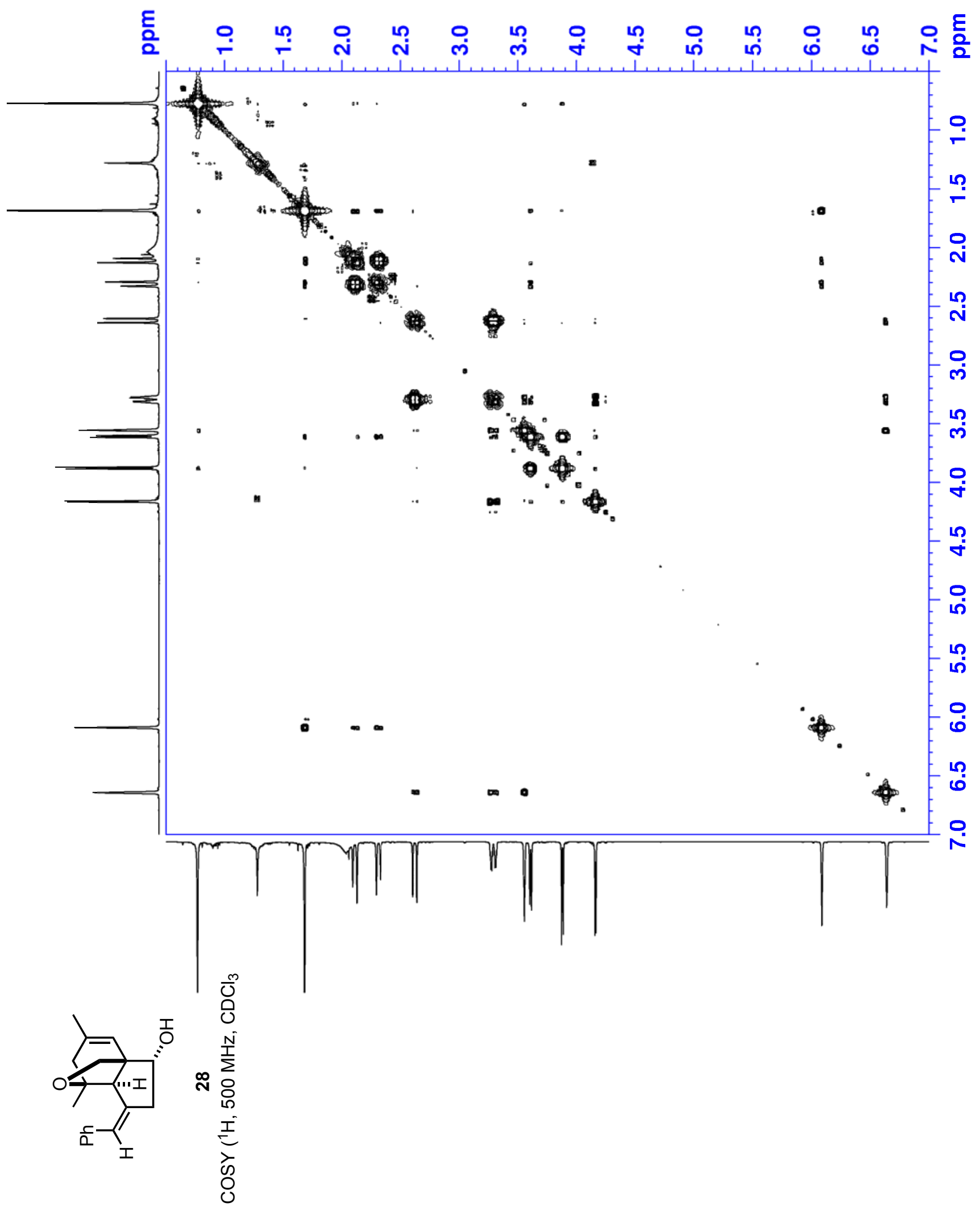




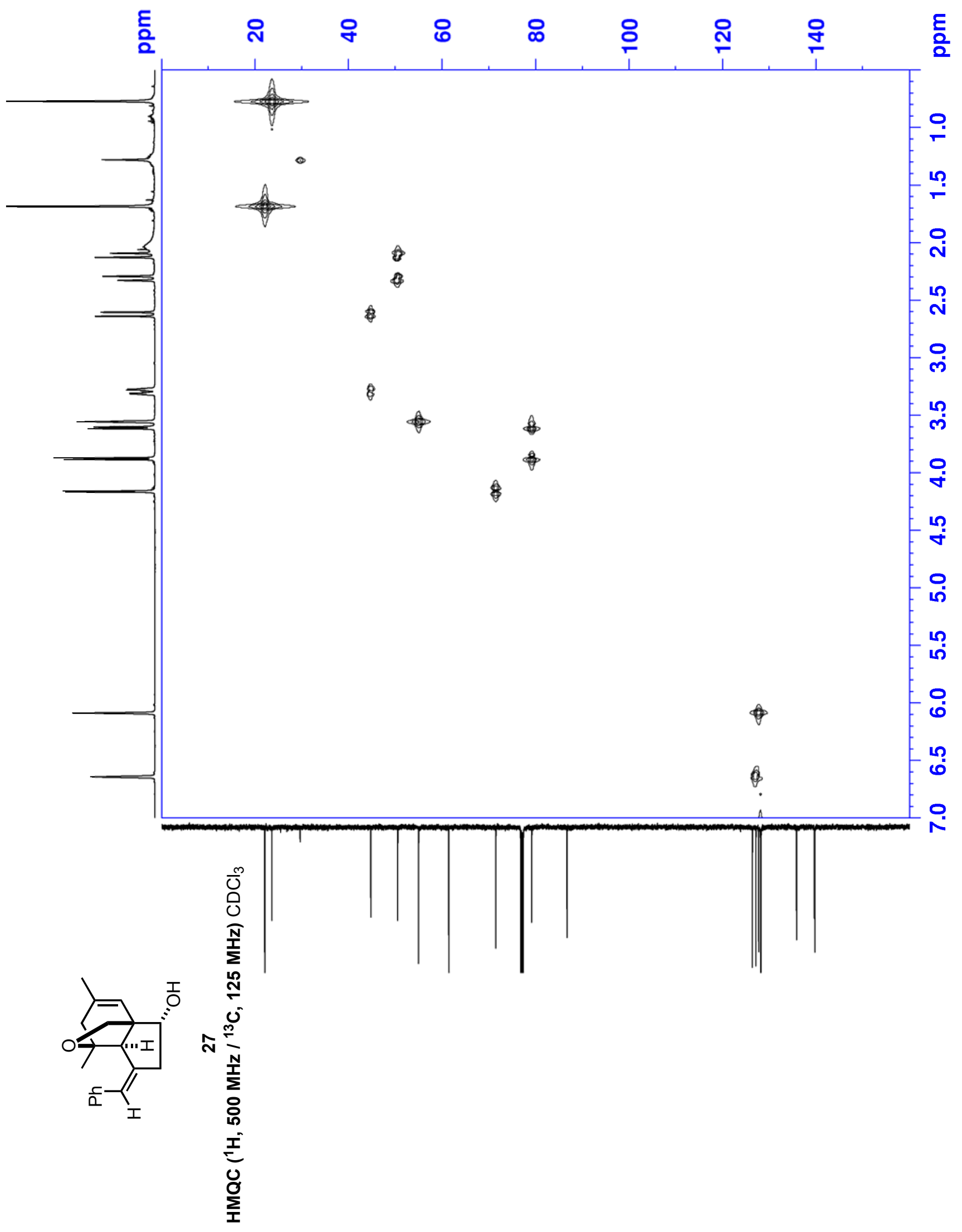




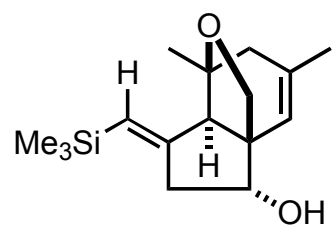

29

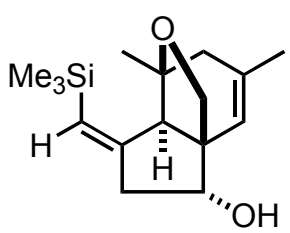

30

Vinylsilanes 29 and 30 . To a solution of $5.26 \mathrm{~g}(14.7 \mathrm{mmol})$ of 12 in $1.5 \mathrm{~L}$ of dry, degassed benzene at $100^{\circ} \mathrm{C}$ was added $8.57 \mathrm{~g}(29.4 \mathrm{mmol})$ of tri- $n$-butylstannane and 120.8 $\mathrm{mg}(0.74 \mathrm{mmol})$ of azo-bis-isobutyronitrile in $35 \mathrm{~mL}$ of dry, degassed benzene over a period of $45 \mathrm{~min}$. The mixture was warmed under reflux for $1 \mathrm{~h}$, and then concentrated in vacuo. The residual crude oil was chromatographed over $100 \mathrm{~g}$ of silica gel (eluted with hexanes-ethyl acetate, $15: 1 \rightarrow 10: 1)$ to afford $4.09 \mathrm{~g}(99 \%)$ of a $4: 1(E: Z)$ mixture of 29 and 30 , respectively. The less polar $E$ isomer (29) was isolated as a white crystalline solid: $\mathrm{mp} 97-99^{\circ} \mathrm{C}$; IR (thin film) $3414 \mathrm{~cm}^{-1} ;{ }^{1} \mathrm{H}$ NMR (500 MHz, $\left.\mathrm{CDCl}_{3}\right) \delta 0.10\left(\mathrm{~s}, 9 \mathrm{H}, \mathrm{Si}\left(\mathrm{CH}_{3}\right)_{3}\right), 1.53\left(\mathrm{~s}, 3 \mathrm{H}, \mathrm{CH}_{3}\right), 1.66(\mathrm{~s}$, $\left.3 \mathrm{H},=\mathrm{CCH}_{3}\right), 2.03($ br s, $1 \mathrm{H}, \mathrm{OH}), 2.20$ and $2.30\left(\mathrm{ABq}, J=17.5 \mathrm{~Hz}, 2 \mathrm{H}, \mathrm{CH}_{2}\right), 2.50(\mathrm{dd}, J=$ 18.5, $\left.1.5 \mathrm{~Hz}, 1 \mathrm{H}, \underline{\mathrm{C}}_{2} \mathrm{CHOH}\right), 2.79(\mathrm{~s}, 1 \mathrm{H}, \mathrm{CH}), 2.99$ (dm, J = $\left.18.5 \mathrm{~Hz}, 1 \mathrm{H}, \mathrm{C}_{2} \mathrm{CHOH}\right), 3.48$ (d, J = 7.5 Hz, 1H, CH $5.68(\mathrm{~m}, 1 \mathrm{H},=\mathrm{CH}), 5.94\left(\mathrm{~m}, 1 \mathrm{H},=\mathrm{C} \underline{\mathrm{HSi}}\left(\mathrm{CH}_{3}\right)_{3}\right) ;{ }^{13} \mathrm{C} \mathrm{NMR}\left(125 \mathrm{MHz}, \mathrm{CDCl}_{3}\right) \delta-0.4(\mathrm{q}), 22.1$ $(q), 22.2(q), 42.7(t), 50.5(t), 58.0(d), 59.3(s), 71.3(d), 78.9(t), 85.1(s), 125.6(d), 126.3(d)$, 135.4 (s), 155.2 (s); exact mass calcd for $\mathrm{C}_{16} \mathrm{H}_{26} \mathrm{O}_{2} \mathrm{Si}(\mathrm{M}+\mathrm{Na})^{+} \mathrm{m} / \mathrm{z} 301.1600$, found $\mathrm{m} / \mathrm{z}$ 301.1596. 

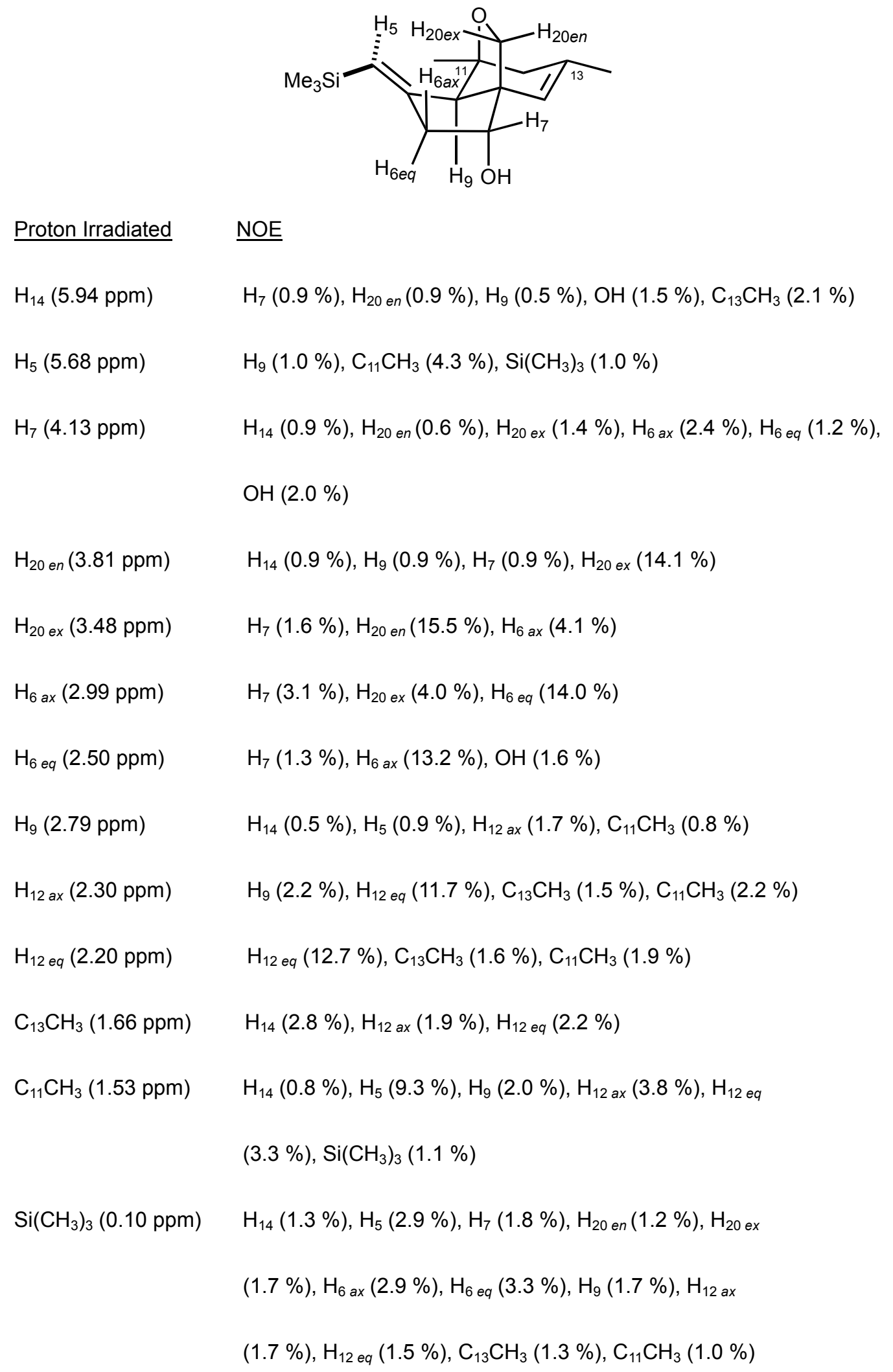
The more polar $Z$ isomer (30) was isolated as a white crystalline solid: mp $122-124{ }^{\circ} \mathrm{C}$; ${ }^{1} \mathrm{H}$ $\operatorname{NMR}\left(500 \mathrm{MHz}, \mathrm{CDCl}_{3}\right) \delta 0.15\left(\mathrm{~s}, 9 \mathrm{H}, \mathrm{Si}\left(\mathrm{CH}_{3}\right)_{3}\right), 1.54\left(\mathrm{~s}, 3 \mathrm{H}, \mathrm{CH}_{3}\right), 1.69\left(\mathrm{~s}, 3 \mathrm{H},=\mathrm{CCH}_{3}\right), 1.71$ (br s, $1 \mathrm{H}, \mathrm{OH}), 2.28$ and $2.33\left(\mathrm{ABq}, J=18.0 \mathrm{~Hz}, 2 \mathrm{H}, \mathrm{CH}_{2}\right), 2.43\left(\mathrm{~d}, J=17.5,1 \mathrm{H}, \underline{\mathrm{C}}_{2} \mathrm{CHOH}\right)$, 2.90 (br s, $1 \mathrm{H}, \mathrm{CH}), 3.29\left(\mathrm{dm}, J=17.5 \mathrm{~Hz}, 1 \mathrm{H}, \mathrm{CH}_{2} \mathrm{CHOH}\right), 3.61\left(\mathrm{~d}, J=7.5 \mathrm{~Hz}, 1 \mathrm{H}, \mathrm{CH}_{2} \mathrm{O}\right)$, $3.91\left(\mathrm{~d}, J=7.5 \mathrm{~Hz}, 1 \mathrm{H}, \mathrm{CH}_{2} \mathrm{O}\right), 4.08(\mathrm{~d}, J=4.5 \mathrm{~Hz}, 1 \mathrm{H}, \underline{\mathrm{CHOH}}), 5.74(\mathrm{~m}, 1 \mathrm{H},=\mathrm{CH}), 6.09(\mathrm{~m}$, $\left.1 \mathrm{H},=\mathrm{C} \underline{\mathrm{HSi}}\left(\mathrm{CH}_{3}\right)_{3}\right) ;{ }^{13} \mathrm{C} \mathrm{NMR}\left(125 \mathrm{MHz}, \mathrm{CDCl}_{3}\right) \delta 0.3$ (q), 22.1 (q), 23.5 (q), 48.6 (t), 50.6 (t), 56.8 (d), 61.8 (s), 71.6 (d), 79.9 (t), 85.8 (s), 128.0 (d), 128.3 (d), 135.6 (s), 154.9 (s); exact mass calcd for $\mathrm{C}_{16} \mathrm{H}_{26} \mathrm{O}_{2} \mathrm{Si}(\mathrm{M}+\mathrm{Na})^{+} \mathrm{m} / \mathrm{z}$ 301.1600, found $\mathrm{m} / \mathrm{z}$ 301.1576. Anal. Calcd for $\mathrm{C}_{16} \mathrm{H}_{26} \mathrm{O}_{2} \mathrm{Si}: \mathrm{C}, 69.01 ; \mathrm{H}, 9.41$. Found: $\mathrm{C}, 68.85 ; \mathrm{H}, 9.38$. 


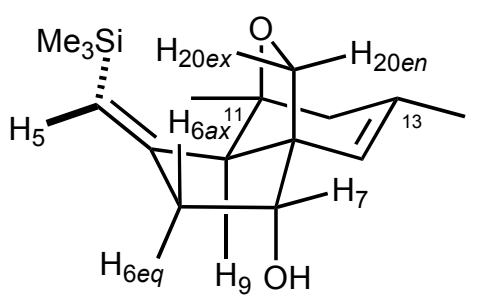

\begin{tabular}{|c|c|}
\hline$\underline{\text { Proton Irradiated }}$ & NOE \\
\hline $\mathrm{H}_{14}(6.09 \mathrm{ppm})$ & $\mathrm{H}_{7}(0.5 \%), \mathrm{H}_{20 \text { en }}(0.5 \%), \mathrm{C}_{13} \mathrm{CH}_{3}(2.1 \%)$ \\
\hline $\mathrm{H}_{5}(5.74 \mathrm{ppm})$ & $\mathrm{H}_{6 \text { ax }}(0.6 \%), \mathrm{H}_{6 \text { eq }}(2.0 \%), \mathrm{Si}\left(\mathrm{CH}_{3}\right)_{3}(1.8 \%)$ \\
\hline \multirow[t]{2}{*}{$\mathrm{H}_{7}(4.08 \mathrm{ppm})$} & $\mathrm{H}_{14}(0.7 \%), \mathrm{H}_{20 \text { en }}(0.5 \%), \mathrm{H}_{20 \text { ex }}(1.4 \%), \mathrm{H}_{6 \text { ax }}(1.9 \%), \mathrm{H}_{6 \text { eq }}(1.1 \%)$ \\
\hline & $\mathrm{C}_{13} \mathrm{CH}_{3}(1.6 \%)$ \\
\hline $\mathrm{H}_{20 \text { en }}(3.91 \mathrm{ppm})$ & $\mathrm{H}_{14}(0.9 \%), \mathrm{H}_{7}(0.5 \%), \mathrm{H}_{20 \text { ex }}(10.3 \%)$ \\
\hline $\mathrm{H}_{20 \text { ex }}(3.61 \mathrm{ppm})$ & $\mathrm{H}_{7}(1.5 \%), \mathrm{H}_{20 \text { en }}(10.9 \%), \mathrm{H}_{6 \text { ax }}(4.2 \%)$ \\
\hline $\mathrm{H}_{6 \text { ax }}(3.29 \mathrm{ppm})$ & $\mathrm{H}_{5}(0.6 \%), \mathrm{H}_{7}(2.2 \%), \mathrm{H}_{20 \text { ex }}(4.4 \%), \mathrm{H}_{6 \text { eq }}(13.2 \%)$ \\
\hline $\mathrm{H}_{6 \mathrm{eq}}(2.43 \mathrm{ppm})$ & $\mathrm{H}_{5}(2.2 \%), \mathrm{H}_{7}(1.1 \%), \mathrm{H}_{6 \text { ax }}(11.6 \%), \mathrm{OH}(1.1 \%)$ \\
\hline $\mathrm{H}_{9}(2.90 \mathrm{ppm})$ & $\mathrm{H}_{12 \text { ax }}(1.2 \%), \mathrm{C}_{11} \mathrm{CH}_{3}(0.7 \%)$ \\
\hline $\mathrm{C}_{13} \mathrm{CH}_{3}(1.69 \mathrm{ppm})$ & $\mathrm{H}_{14}(3.0 \%), \mathrm{H}_{20 \text { en }}(0.5 \%), \mathrm{H}_{9}(0.6 \%), \mathrm{H}_{12 \text { ax }}(1.7 \%), \mathrm{H}_{12 \text { eq }}(1.6 \%)$ \\
\hline \multirow[t]{2}{*}{$\mathrm{C}_{11} \mathrm{CH}_{3}(1.54 \mathrm{ppm})$} & $\mathrm{H}_{5}(1.0 \%), \mathrm{H}_{20 \text { en }}(0.5 \%), \mathrm{H}_{20 \text { ex }}(0.6 \%), \mathrm{H}_{9}(1.4 \%), \mathrm{H}_{12 \text { ax }}(2.6 \%)$, \\
\hline & $\mathrm{H}_{12 \text { eq }}(2.2 \%), \mathrm{Si}\left(\mathrm{CH}_{3}\right)_{3}(6.7 \%)$ \\
\hline $\mathrm{Si}\left(\mathrm{CH}_{3}\right)_{3}(0.15 \mathrm{ppm})$ & $\mathrm{H}_{5}(3.3 \%), \mathrm{H}_{9}(4.1 \%), \mathrm{H}_{6 \text { eq }}(2.1 \%), \mathrm{C}_{13} \mathrm{CH}_{3}(1.3 \%), \mathrm{C}_{11} \mathrm{CH}_{3}(6.7 \%)$ \\
\hline
\end{tabular}




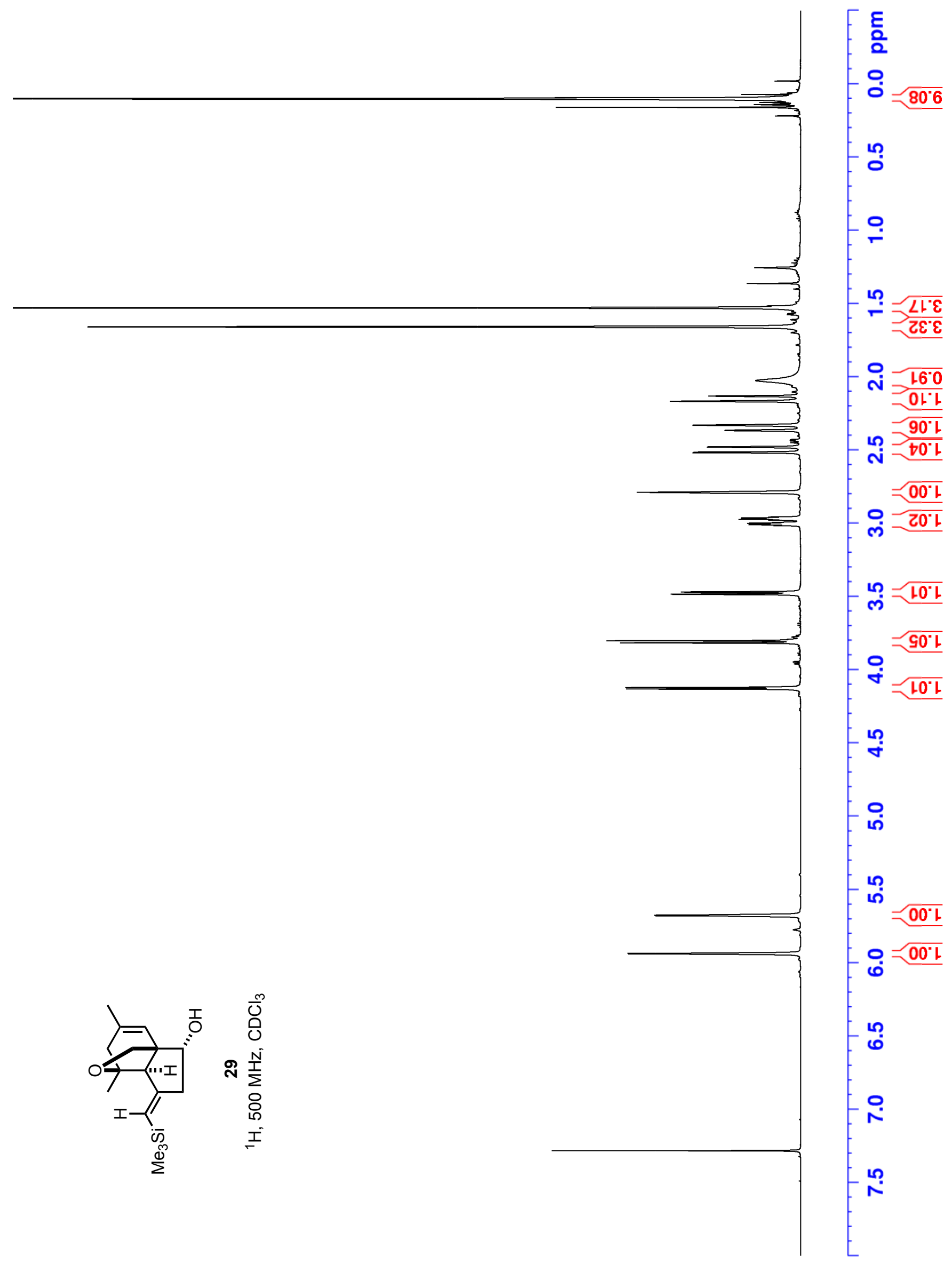




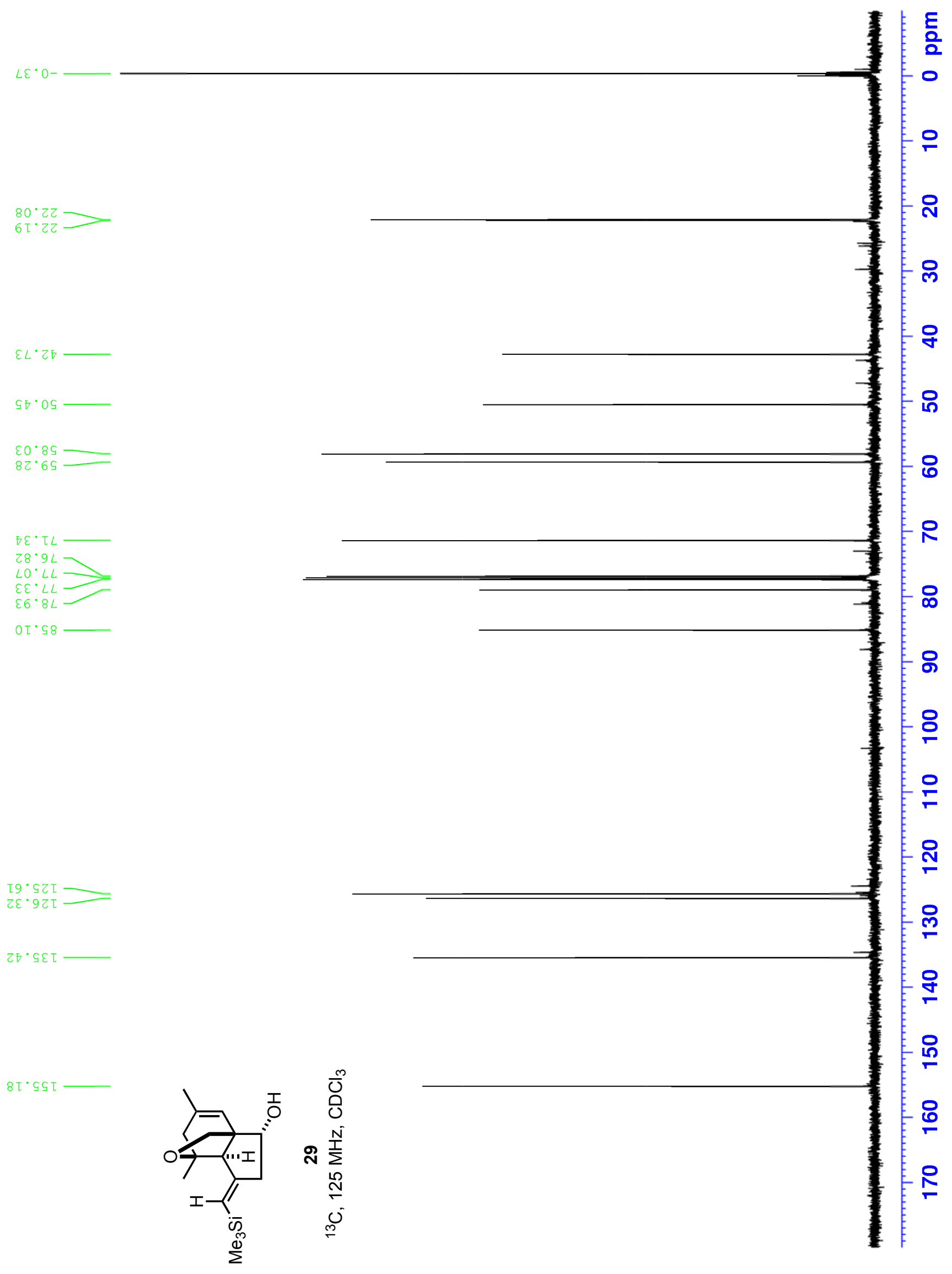




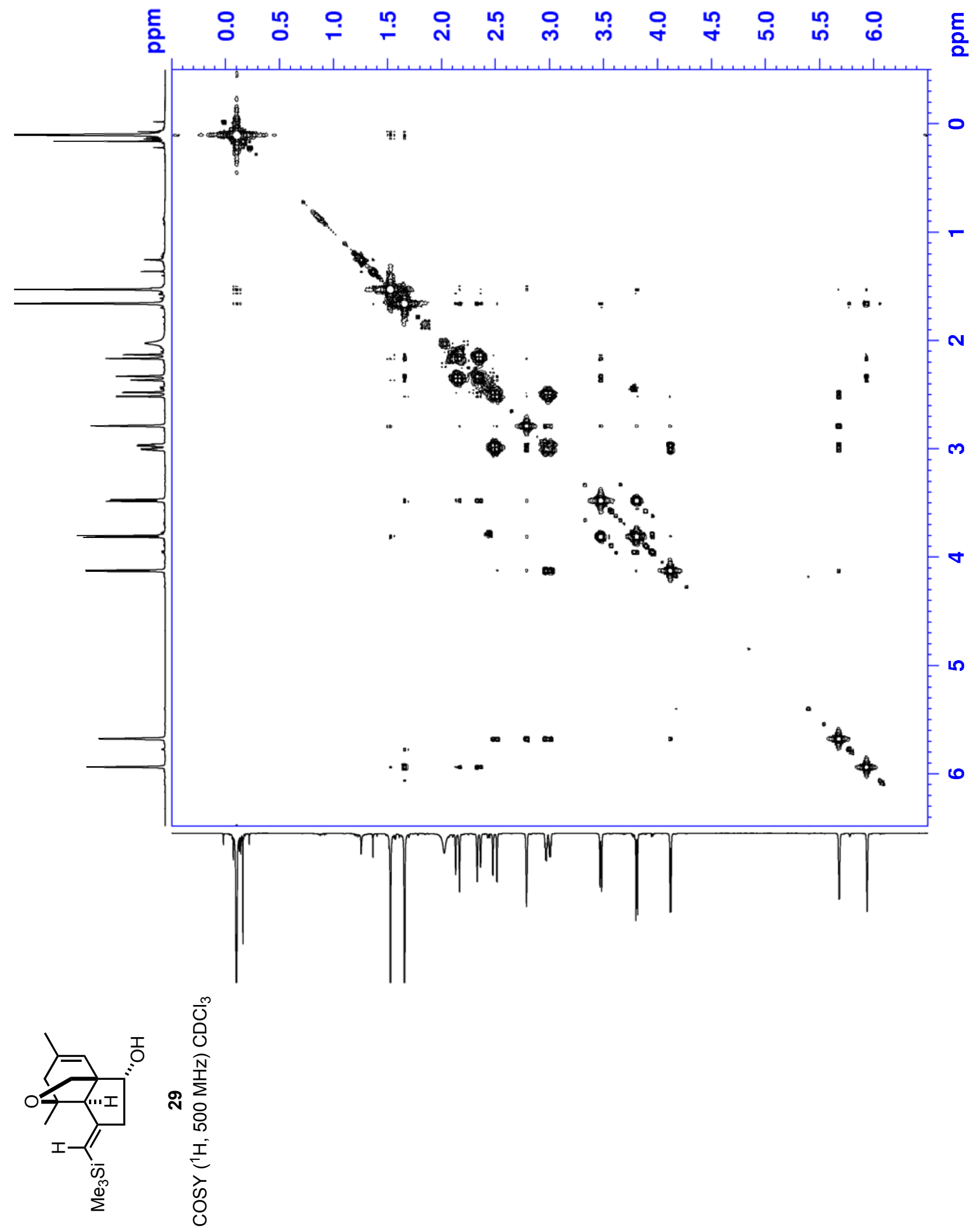




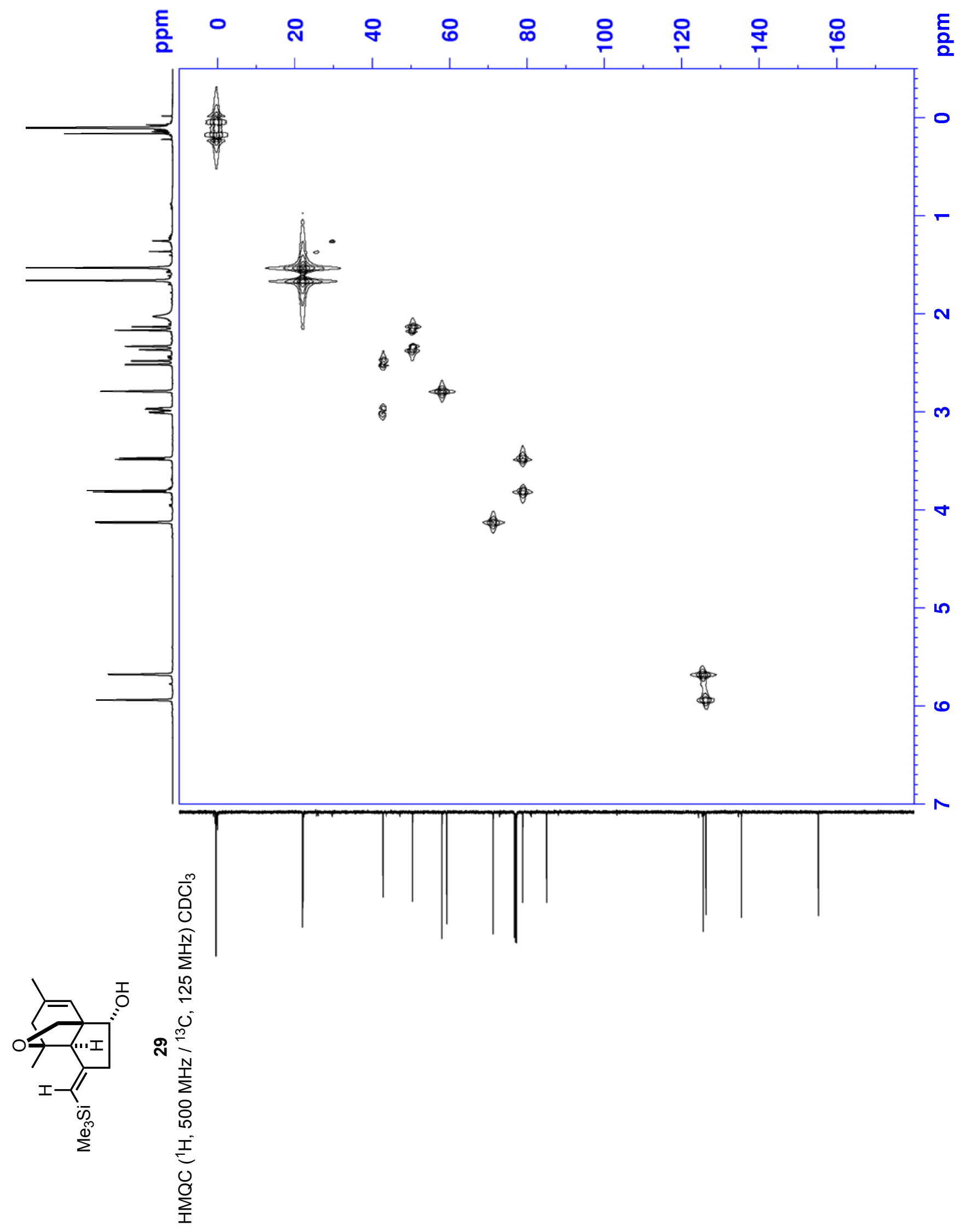




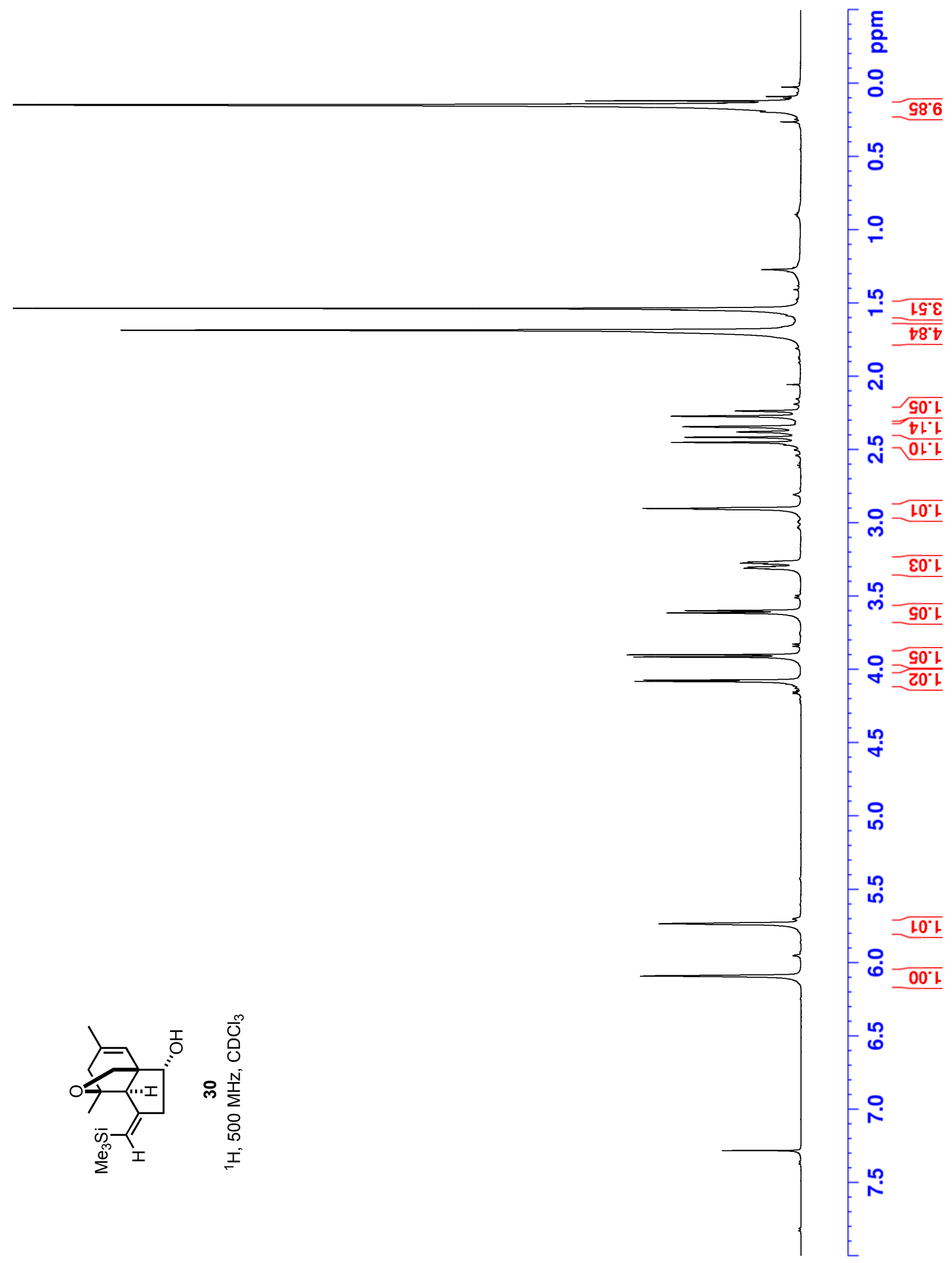




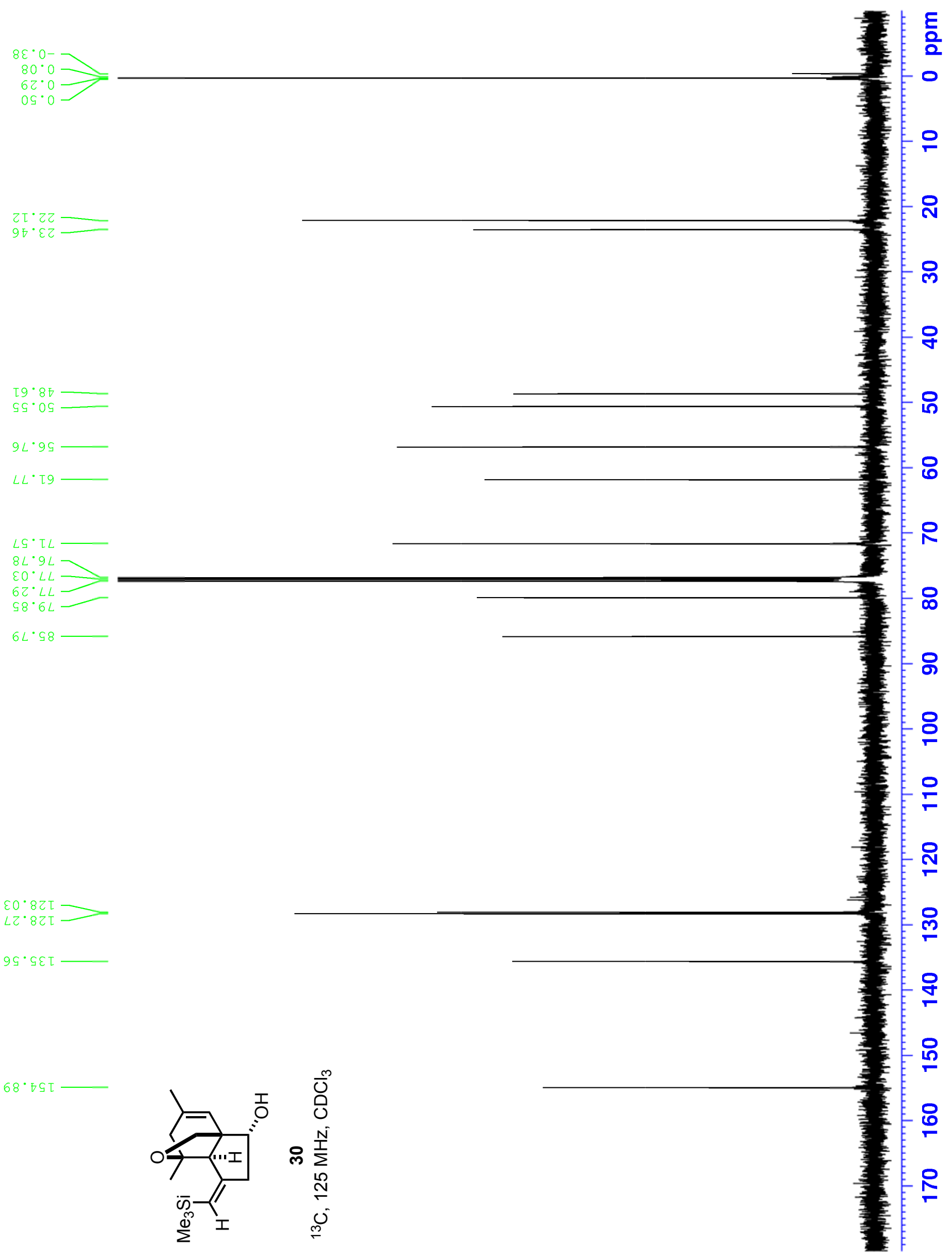




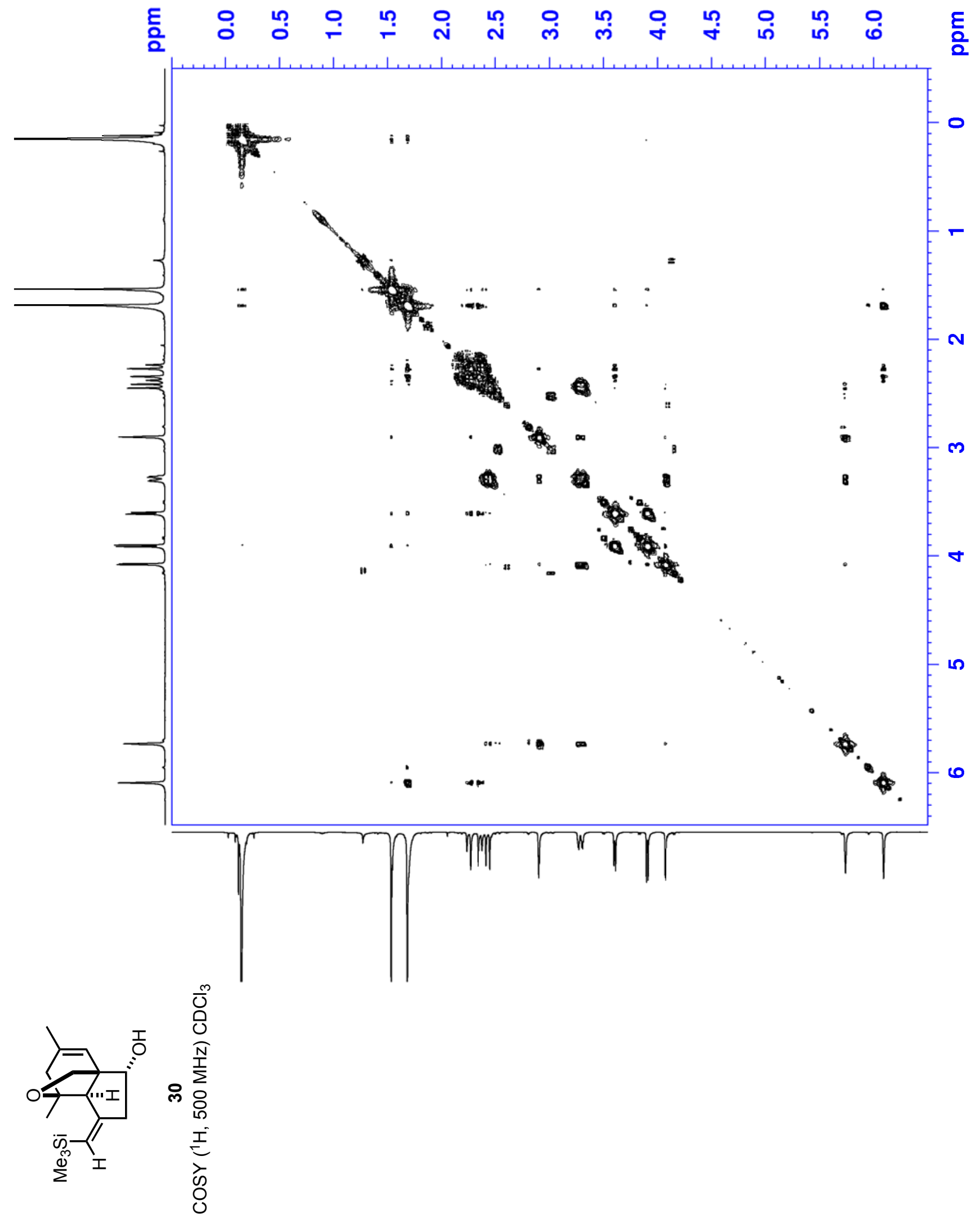




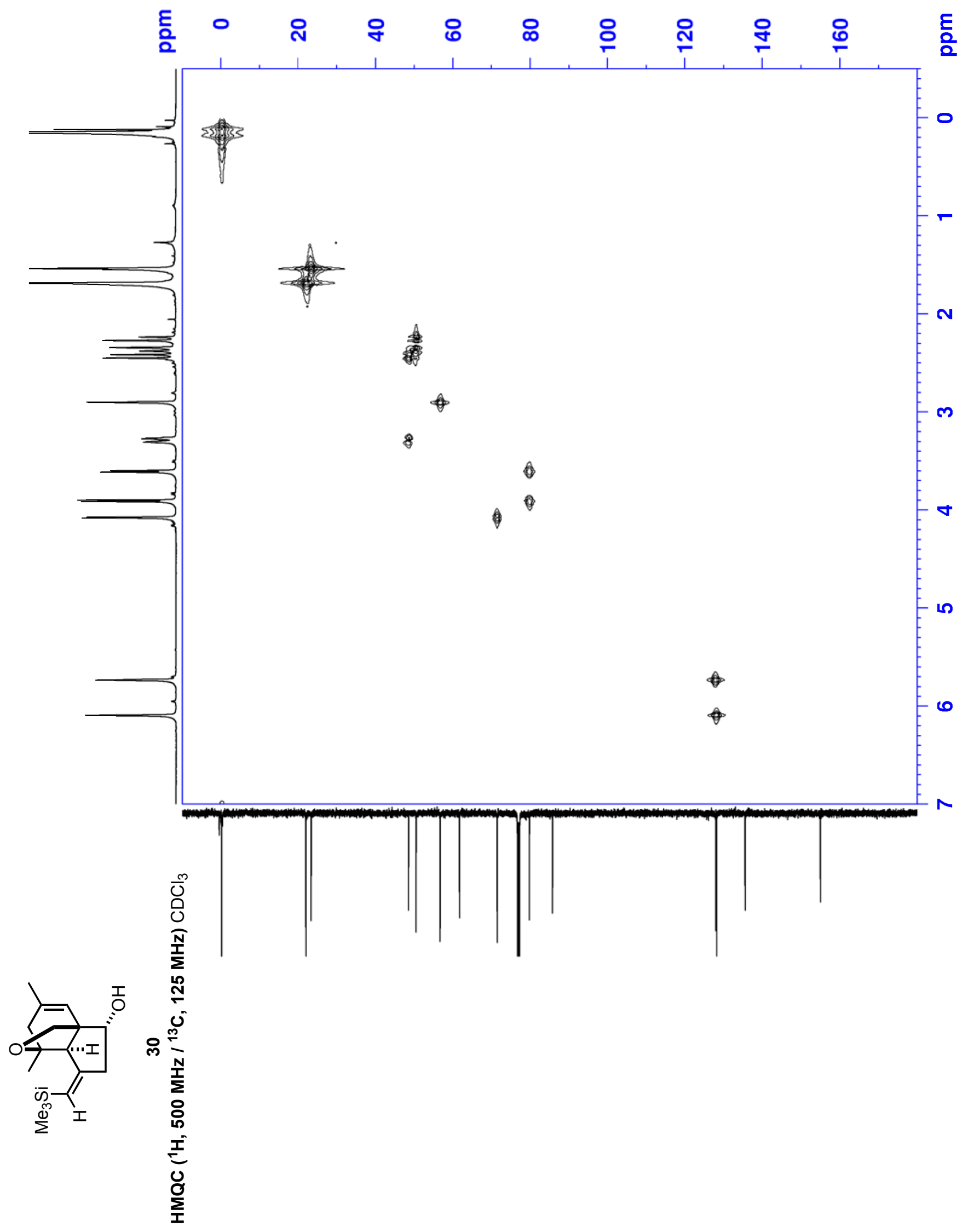




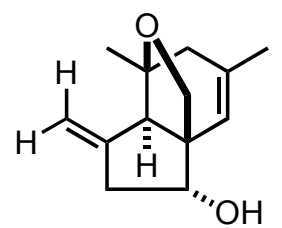

31

Perhydroindan 31. To a solution of $724 \mathrm{mg}(2.54 \mathrm{mmol})$ of 13 and $63 \mathrm{mg}(0.38 \mathrm{mmol})$ of azo-bis-isobutyronitrile in $250 \mathrm{~mL}$ of dry, degassed benzene at $100{ }^{\circ} \mathrm{C}$ was added $2.22 \mathrm{~g}$ (7.62 mmol) of tri-n-butylstannane in $8 \mathrm{~mL}$ of dry, degassed benzene over a period of $30 \mathrm{~min}$. The mixture was warmed under reflux for $2.5 \mathrm{~h}$, and then concentrated in vacuo to give a pale yellow oil. The crude oil was purified by chromatography over $15 \mathrm{~g}$ of silica gel (eluted with hexanes-ethyl acetate, 20:1), followed by MPLC chromatography over a Lobar size B column (eluted with dichloromethane-ethyl acetate, 40:1). The trans-perhydroindan 31 was isolated as a water-white oil (125 mg, 24\%); IR (thin film) 3413, $1654 \mathrm{~cm}^{-1} ;{ }^{1} \mathrm{H}$ NMR (500 MHz, $\mathrm{CDCl}_{3}$ ) $\delta 1.54\left(\mathrm{~s}, 3 \mathrm{H}, \mathrm{CH}_{3}\right), 1.66\left(\mathrm{~s}, 3 \mathrm{H},=\mathrm{CCH}_{3}\right), 1.93(\mathrm{br} \mathrm{s}, 1 \mathrm{H}, \mathrm{OH}), 2.23,2.32(\mathrm{ABq}, \mathrm{J}=17.8 \mathrm{~Hz}$ $2 \mathrm{H}, \mathrm{CH}_{2}$ ), 2.52 (d, J = $\left.18.5 \mathrm{~Hz}, 1 \mathrm{H}, \underline{\mathrm{C}}_{2} \mathrm{CHOH}\right), 2.80(\mathrm{~d}, J=2.5 \mathrm{~Hz}, 1 \mathrm{H}, \mathrm{CH}), 3.05(\mathrm{~m}, 1 \mathrm{H}$, $\left.\mathrm{CH}_{2} \mathrm{CHOH}\right), 3.50\left(\mathrm{~d}, J=7.5 \mathrm{~Hz}, 1 \mathrm{H}, \mathrm{CH}_{2} \mathrm{O}\right), 3.83\left(\mathrm{~d}, J=7.5 \mathrm{~Hz}, 1 \mathrm{H}, \mathrm{CH}_{2} \mathrm{O}\right), 4.11(\mathrm{~d}, J=5.0$ $\mathrm{Hz}, 1 \mathrm{H}, \underline{\mathrm{CHOH}}), 5.15-5.18\left(\mathrm{~m}, 2 \mathrm{H},=\underline{\mathrm{C}}_{2}\right), 5.96(\mathrm{~m}, 1 \mathrm{H},=\mathrm{C} \underline{\mathrm{H}}) ;{ }^{13} \mathrm{C} \mathrm{NMR}\left(125 \mathrm{MHz}, \mathrm{CDCl}_{3}\right) \delta$ $22.1(\mathrm{q}), 22.2(\mathrm{q}), 43.0(\mathrm{t}), 50.1(\mathrm{t}), 55.9(\mathrm{~d}), 60.3(\mathrm{~s}), 71.2(\mathrm{~d}), 79.0(\mathrm{t}), 84.7(\mathrm{~s}), 111.2(\mathrm{t})$, 126.3 (d), 135.5 (s), 146.4 (s); exact mass calcd for $\mathrm{C}_{13} \mathrm{H}_{18} \mathrm{O}_{2}(\mathrm{M}+\mathrm{Na})^{+} \mathrm{m} / \mathrm{z} 229.1204$, found 229.1208. 


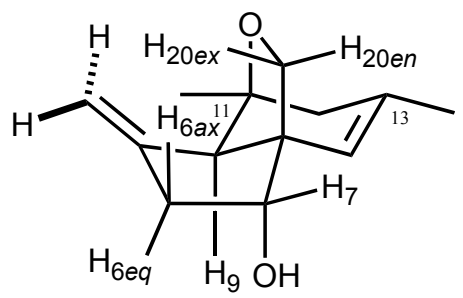

\begin{tabular}{|c|c|}
\hline Proton Irradiated & $\underline{\mathrm{NOE}}$ \\
\hline $\mathrm{H}_{7}(4.11 \mathrm{ppm})$ & $\mathrm{H}_{20 \text { en }}(0.5 \%), \mathrm{H}_{20 \text { ex }}(1.1 \%), \mathrm{H}_{6 \text { ax }}(1.3 \%), \mathrm{H}_{6 \text { eq }}(0.8 \%), \mathrm{OH}(1.4 \%)$ \\
\hline $\mathrm{H}_{20 \text { en }}(3.83 \mathrm{ppm})$ & $\mathrm{H}_{20 \text { ex }}(5.9 \%)$ \\
\hline $\mathrm{H}_{20 \text { ex }}(3.50 \mathrm{ppm})$ & $\mathrm{H}_{7}(0.9 \%), \mathrm{H}_{20 \text { en }}(6.2 \%), \mathrm{H}_{6 \text { ax }}(1.9 \%)$ \\
\hline $\mathrm{H}_{6 \mathrm{ax}}(3.05 \mathrm{ppm})$ & $\mathrm{H}_{7}(1.4 \%), \mathrm{H}_{20 \text { ex }}(2.1 \%), \mathrm{H}_{6 \text { eq }}(8.2 \%)$ \\
\hline $\mathrm{H}_{9}(2.80 \mathrm{ppm})$ & $\mathrm{H}_{6 \text { ax }}(0.7 \%), \mathrm{H}_{6 \text { eq }}(1.0 \%), \mathrm{H}_{12 \text { ax }}(0.9 \%), \mathrm{C}_{11} \mathrm{CH}_{3}(0.6 \%)$ \\
\hline $\mathrm{H}_{6 \text { e }}(2.52 \mathrm{ppm})$ & $\mathrm{H}_{7}(0.6 \%), \mathrm{H}_{6 \text { ax }}(9.1 \%), \mathrm{OH}(0.7 \%)$ \\
\hline $\mathrm{H}_{12 \text { ax }}(2.32 \mathrm{ppm})$ & $\mathrm{H}_{9}(0.8 \%), \mathrm{H}_{12 \text { eq }}(4.5 \%), \mathrm{C}_{13} \mathrm{CH}_{3}(0.8 \%), \mathrm{C}_{11} \mathrm{CH}_{3}(1.2 \%)$ \\
\hline $\mathrm{H}_{12 \text { eq }}(2.23 \mathrm{ppm})$ & $\mathrm{H}_{12 \text { ax }}(3.2 \%), \mathrm{C}_{13} \mathrm{CH}_{3}(0.9 \%), \mathrm{C}_{11} \mathrm{CH}_{3}(1.1 \%)$ \\
\hline $\mathrm{C}_{13} \mathrm{CH}_{3}(1.68 \mathrm{ppm})$ & $\mathrm{H}_{12 \text { ax }}(1.0 \%), \mathrm{H}_{12 \text { eq }}(1.0 \%)$ \\
\hline $\mathrm{C}_{11} \mathrm{CH}_{3}(1.54 \mathrm{ppm})$ & $\mathrm{H}_{9}(1.0 \%), \mathrm{H}_{12 \text { ax }}(1.9 \%), \mathrm{H}_{12 \text { eq }}(1.6 \%)$ \\
\hline
\end{tabular}




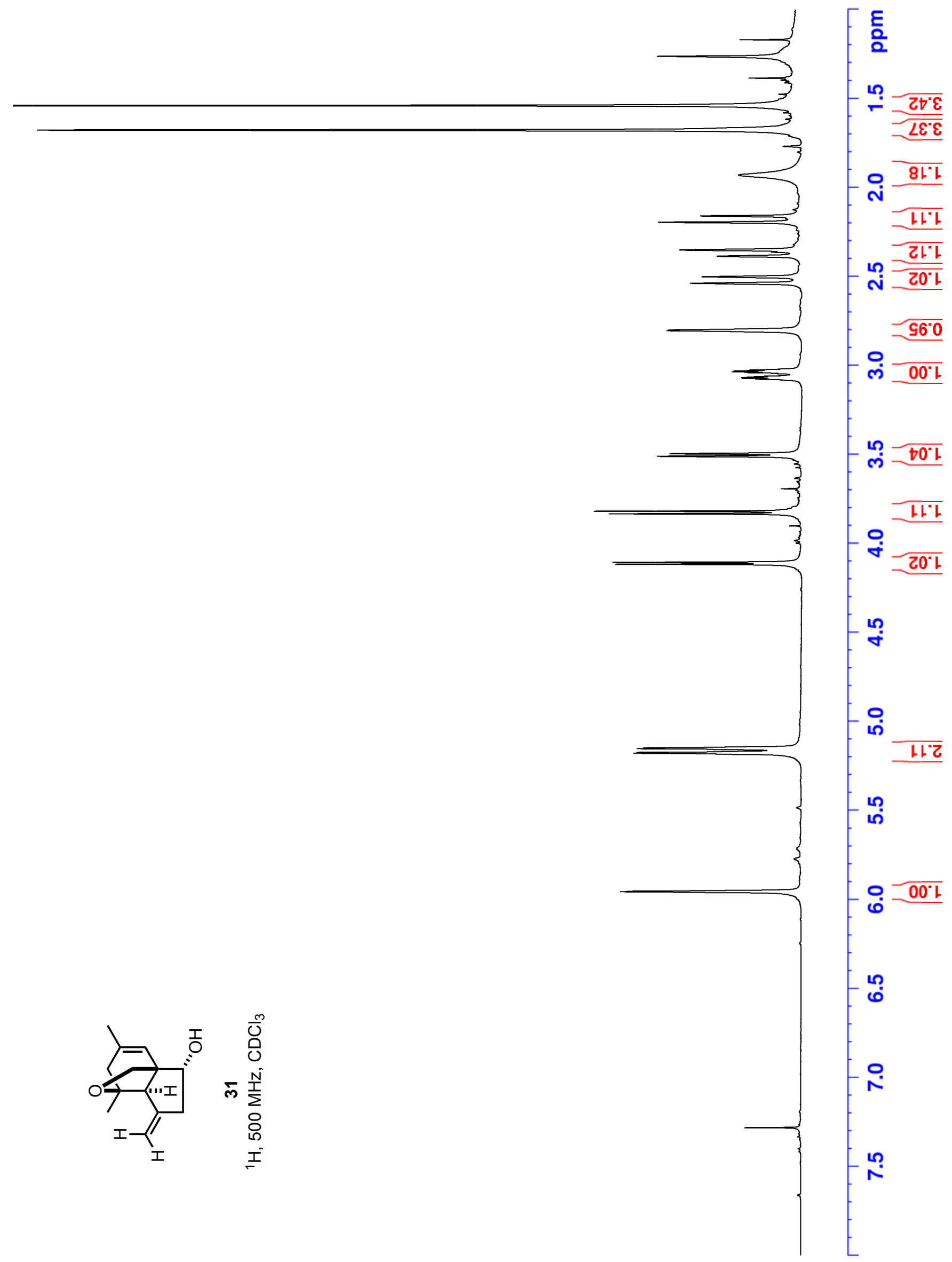




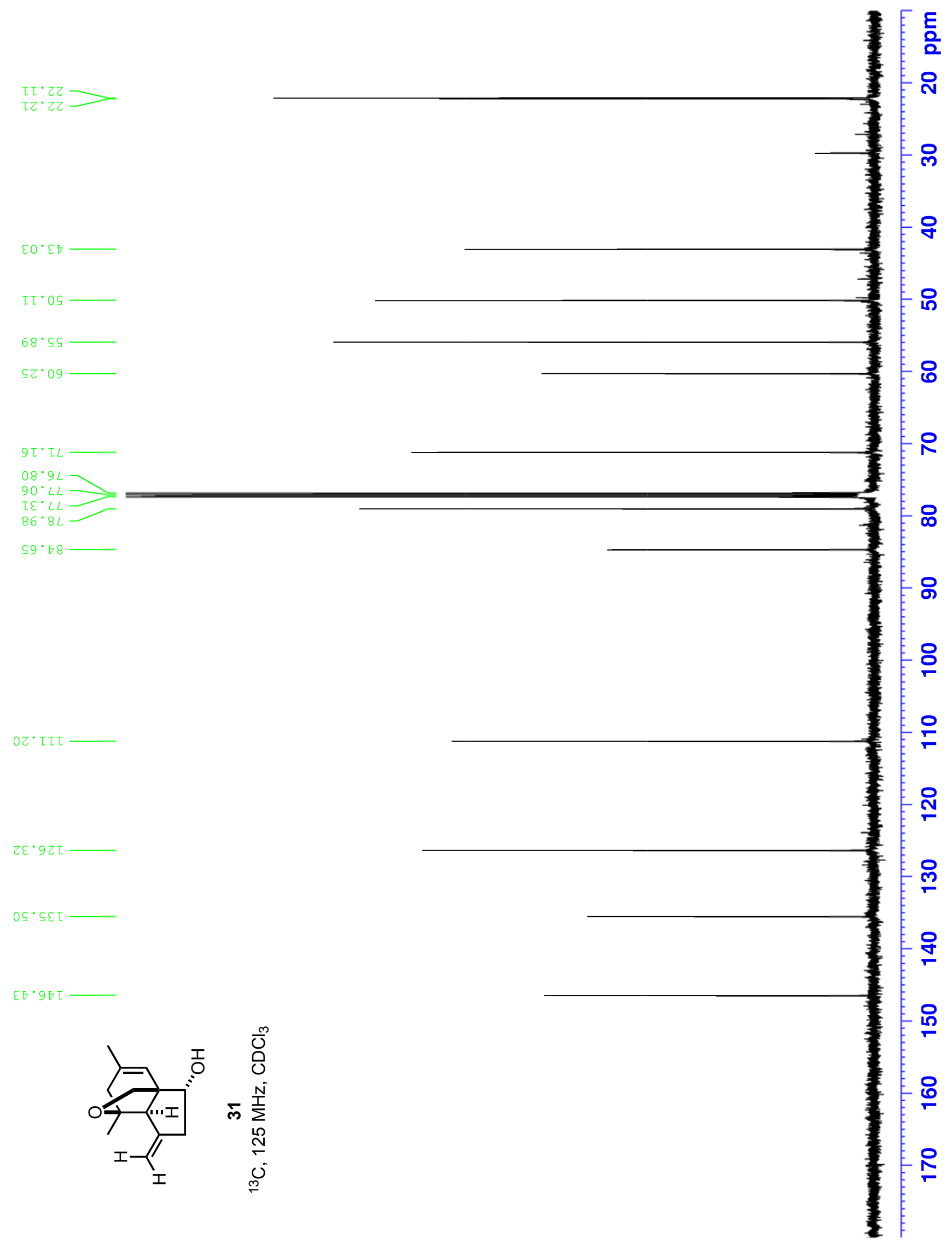




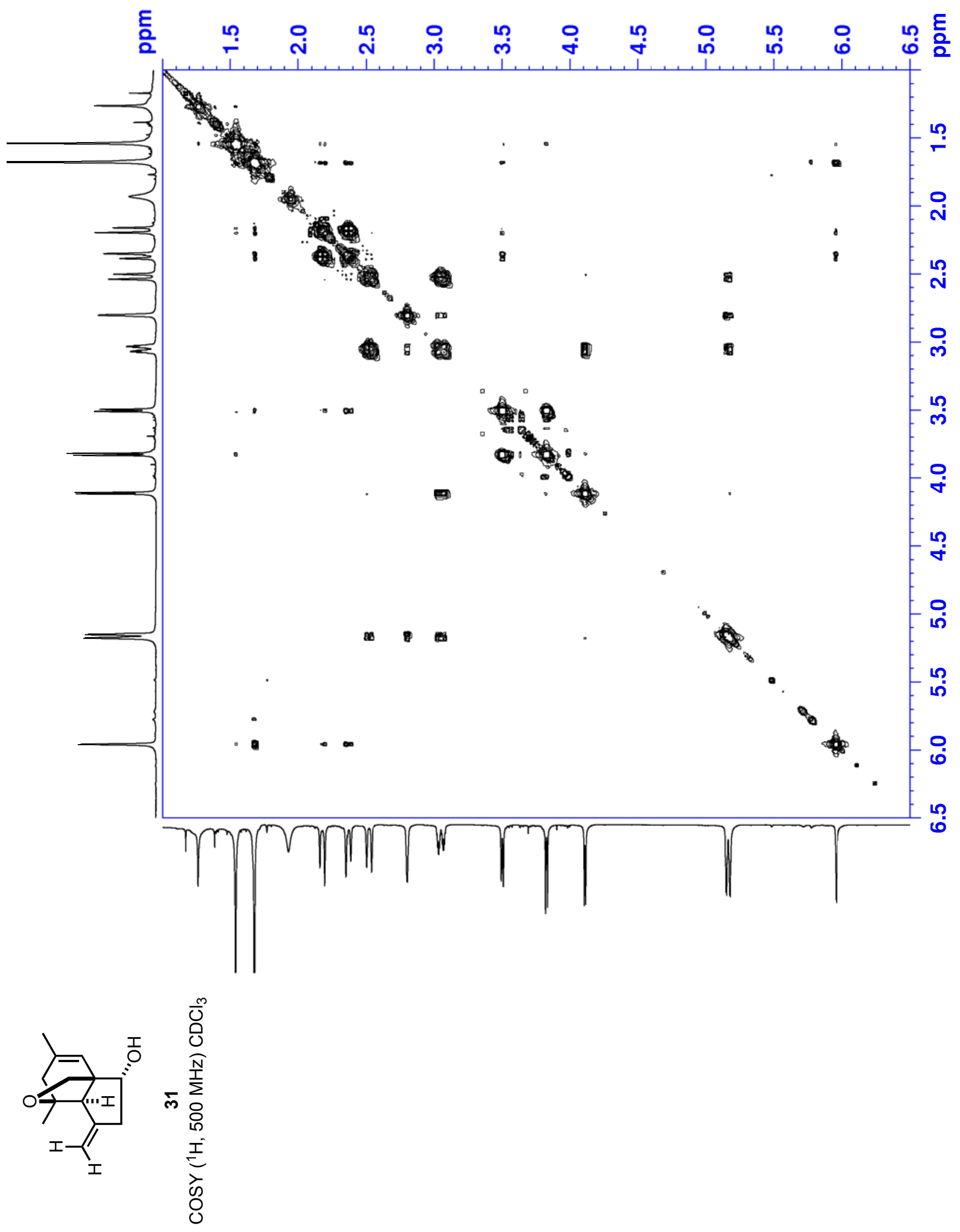




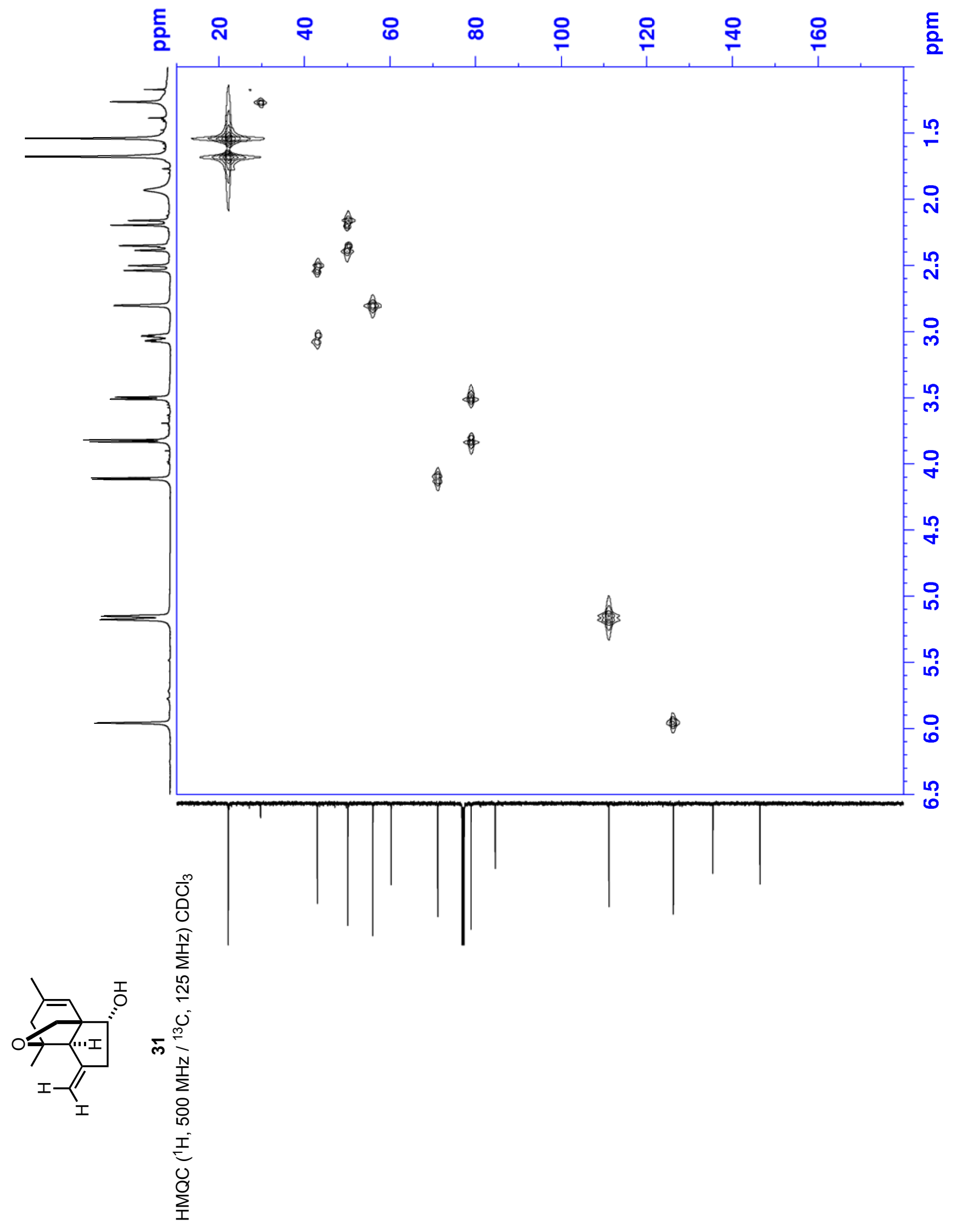




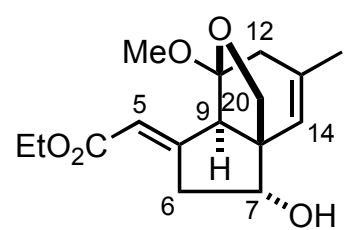

32

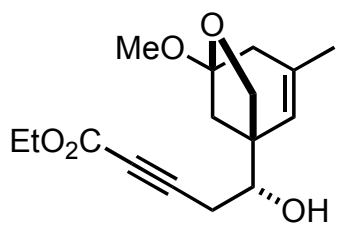

des-Br-22

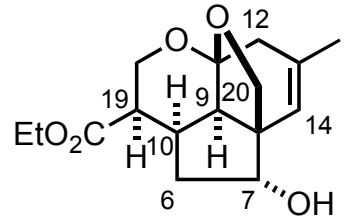

33

A. Normal Tin Hydride Concentration: A solution of $115 \mathrm{mg}(0.308 \mathrm{mmol})$ of bromide 22, $184 \mathrm{mg}(0.632 \mathrm{mmol})$ of tri- $n$-butyltin hydride, and $3 \mathrm{mg}(0.02 \mathrm{mmol})$ of azo-bis-isobutyronitrile in $35 \mathrm{~mL}$ of dry, degassed benzene was warmed to reflux (oil bath $100^{\circ} \mathrm{C}$ ) for $45 \mathrm{~min}$. The solvent was removed in vacuo and the residue chromatographed over $3 \mathrm{~g}$ of silica gel (hexanes-ethyl acetate, $30: 1)$ to afford $38 \mathrm{mg} \mathrm{(42 \% )}$ of trans-perhydroindan 32 as a colorless oil contaminated with tin impurity: IR (neat) 3452, 1712 , $1652 \mathrm{~cm}^{-1} ;{ }^{1} \mathrm{H}$ NMR $\left(\mathrm{C}_{6} \mathrm{D}_{6}, 500 \mathrm{MHz}\right) \delta 0.99\left(\mathrm{t}, \mathrm{J}=7.1 \mathrm{~Hz}, 3 \mathrm{H}, \mathrm{CH}_{2} \mathrm{CH}_{3}\right), 1.37$ (br s, $\left.1 \mathrm{H}, \mathrm{OH}\right)$, $1.47\left(\mathrm{~s}, 3 \mathrm{H}, \mathrm{CH}_{3}\right), 2.21,2.40\left(\mathrm{AB}_{\mathrm{q}}, J=16.5 \mathrm{~Hz}, 2 \mathrm{H}, \mathrm{C}(12) \mathrm{H}_{2}\right), 2.99(\mathrm{~s}, 1 \mathrm{H}, \mathrm{C}(9) \mathrm{H}), 3.11$ (dd, J $\left.=20.7,2.4 \mathrm{~Hz}, 1 \mathrm{H}, \mathrm{C}(6) \mathrm{H}_{e q}\right), 3.27\left(\mathrm{~s}, 3 \mathrm{H}, \mathrm{OCH}_{3}\right), 3.39(\mathrm{~d}, J=7.6 \mathrm{~Hz}, 1 \mathrm{H}, \mathrm{C}(20) \mathrm{H}), 3.52-3.59$ $\left(\mathrm{m}, 1 \mathrm{H}, \mathrm{C}(6) \mathrm{H}_{a x}\right), 3.56(\mathrm{~d}, J=7.5 \mathrm{~Hz}, 1 \mathrm{H}, \mathrm{C}(20) \mathrm{H}), 3.64(\mathrm{~d}, J=5.3 \mathrm{~Hz}, 1 \mathrm{H}, \mathrm{C}(7) \mathrm{H}), 4.05(\mathrm{q}, J$ $\left.=7.1 \mathrm{~Hz}, 2 \mathrm{H}, \underline{\mathrm{C}}_{2} \mathrm{CH}_{3}\right), 5.70(\mathrm{~s}, 1 \mathrm{H}, \mathrm{C}(14) \mathrm{H}), 6.89(\mathrm{q}, J=2.5 \mathrm{~Hz}, 1 \mathrm{H}, \mathrm{C}(5) \mathrm{H}) ;{ }^{13} \mathrm{C} N M R\left(\mathrm{C}_{6} \mathrm{D}_{6}\right.$, $125 \mathrm{MHz}) \delta 14.1(\mathrm{q}), 21.8(\mathrm{q}), 43.7(\mathrm{t}), 45.0(\mathrm{t}), 50.4(\mathrm{q}), 56.1(\mathrm{~d}), 58.6(\mathrm{~s}), 59.4(\mathrm{t}), 70.6(\mathrm{~d})$, 77.2 (t), 110.5 (s), 117.7 (d), 126.6 (d), 134.4 (s), 159.3 (s), 166.6 (s); exact mass calcd. for $\mathrm{C}_{16} \mathrm{H}_{22} \mathrm{O}_{5}(\mathrm{M}+\mathrm{Na})^{+} \mathrm{m} / \mathrm{z} 317.1365$, found $\mathrm{m} / \mathrm{z}$ 317.1360. Anal. calcd. for $\mathrm{C}_{16} \mathrm{H}_{22} \mathrm{O}_{5}: \mathrm{C}, 65.29 ; \mathrm{H}$, 7.53. Found: C, 64.56; $\mathrm{H}, 7.73$.

Continued elution (hexanes-ethyl acetate, $30: 1)$ gave a $19 \mathrm{mg}(21 \%)$ of a $1: 10$ mixture of trans-perhydroindan 32 and tetracycle 33, respectively. Further elution with the same solvent system afforded $28 \mathrm{mg}(31 \%)$ of tetracycle 33 as a white solid: $\mathrm{mp} 105-108^{\circ} \mathrm{C}$; IR (thin film) 3446, 1724, $1638 \mathrm{~cm}^{-1} ;{ }^{1} \mathrm{H}$ NMR $\left(\mathrm{C}_{6} \mathrm{D}_{6}, 500 \mathrm{MHz}\right) \delta 1.15(\mathrm{t}, \mathrm{J}=7.3 \mathrm{~Hz}, 3 \mathrm{H}$, 
$\left.\mathrm{CH}_{2} \mathrm{C}_{3}\right), 1.58\left(\mathrm{~s}, 3 \mathrm{H}, \mathrm{C}(21) \mathrm{H}_{3}\right), 1.70$ (br s, $\left.1 \mathrm{H}, \mathrm{OH}\right), 2.04$ (dd, J = 14.8, 9.8 Hz, 1H, C(6) $\mathrm{H}_{e q}$ ), 2.46-2.49 (m, 1H, C(19)H), $2.51(\mathrm{~d}, J=11.5 \mathrm{~Hz}, 1 \mathrm{H}, \mathrm{C}(9) \mathrm{H}), 2.59$ and $2.68\left(\mathrm{AB}_{\mathrm{q}}, J=16.3 \mathrm{~Hz}\right.$, $\left.2 \mathrm{H}, \mathrm{C}(12) \mathrm{H}_{2}\right), 2.60-2.66(\mathrm{~m}, 1 \mathrm{H}, \mathrm{C}(10) \mathrm{H}), 3.52\left(\mathrm{ddd}, J=14.5,8.8,4.5 \mathrm{~Hz}, 1 \mathrm{H}, \mathrm{C}(6) \mathrm{H}_{a x}\right), 3.57$ (dd, $\left.J=11.0,3.5 \mathrm{~Hz}, 1 \mathrm{H}, \mathrm{OCH}_{11 \text { ax }}\right), 3.74\left(\operatorname{app~t}, J=8.5 \mathrm{~Hz}, 2 \mathrm{H}, \mathrm{C}(20) \mathrm{H}_{2}\right), 3.97(\mathrm{~d}, J=4.0 \mathrm{~Hz}$, $1 \mathrm{H}, \mathrm{C}(7) \mathrm{H}), 4.10-4.18\left(\mathrm{~m}, 2 \mathrm{H}, \underline{\mathrm{H}}_{2} \mathrm{CH}_{3}\right), 4.71\left(\mathrm{dd}, J=11.0,5.0 \mathrm{~Hz}, 1 \mathrm{H}, \mathrm{OCH}_{11}\right.$ eq $), 6.01(\mathrm{~m}, 1 \mathrm{H}$, $\mathrm{C}(14) \mathrm{H}) ;{ }^{13} \mathrm{C} N M R\left(\mathrm{C}_{6} \mathrm{D}_{6}, 125 \mathrm{MHz}\right) \delta 14.0(\mathrm{q}), 22.2(\mathrm{q}), 31.4(\mathrm{~d}), 38.2(\mathrm{t}), 39.1(\mathrm{~d}), 48.1(\mathrm{t})$, $49.5(\mathrm{~d}), 59.5(\mathrm{~s}), 59.9(\mathrm{t}), 63.7(\mathrm{t}), 74.3(\mathrm{~d}), 77.0(\mathrm{t}), 108.1(\mathrm{~s}), 129.4(\mathrm{~d}), 134.9(\mathrm{~s}), 170.9(\mathrm{~s})$ exact mass calcd. for $\mathrm{C}_{16} \mathrm{H}_{22} \mathrm{O}_{5}(\mathrm{M}+\mathrm{Na})^{+} \mathrm{m} / \mathrm{z} 317.1365$, found $\mathrm{m} / \mathrm{z} 317.1374$. Anal. calcd. for $\mathrm{C}_{16} \mathrm{H}_{22} \mathrm{O}_{5}: \mathrm{C}, 65.29 ; \mathrm{H}, 7.53$. Found: $\mathrm{C}, 65.06 ; \mathrm{H}, 7.51$.

B. High Effective Tin Hydride Concentration: A solution of $445 \mathrm{mg}(1.19 \mathrm{mmol})$ of bromide 22, $3.47 \mathrm{~g}(11.9 \mathrm{mmol})$ of tri- $n$-butyltin hydride, and $2 \mathrm{mg}(0.012 \mathrm{mmol})$ of azo-bis-isobutyronitrile in $119 \mathrm{~mL}$ of dry, degassed benzene was warmed to reflux (oil bath $100{ }^{\circ} \mathrm{C}$ ) for $3 \mathrm{~h}$. The solvent was removed in vacuo and the residue was purified by chromatography over $75 \mathrm{~g}$ of silica gel (gradient elution with hexanes-ethyl acetate [20:1 (1200 mL), 10:1 (440 mL), 5:1 (300 mL), 1:1 (400 mL)] to give $263 \mathrm{mg}(75 \%)$ of trans-perhydroindan 32 as a yellow oil with tin impurities, $46 \mathrm{mg}(13 \%)$ of a 1:1 mixture of trans-perhydroindan 32 to tetracycle 34 , and $36 \mathrm{mg}(10 \%)$ of tetracycle 33 as a colorless oil with some tin impurity.

C. Low effective concentration of $n-\mathrm{Bu}_{3} \mathrm{SnH}$ : To a solution of $388 \mathrm{mg}(1.04 \mathrm{mmol})$ of 22 in $100 \mathrm{~mL}$ of dry, degassed benzene at $100{ }^{\circ} \mathrm{C}$ was added $17 \mathrm{mg}(0.1 \mathrm{mmol})$ of azo-bis-isobutyronitrile and $302 \mathrm{mg}(4.02 \mathrm{mmol})$ of tri-n-butylstannane in $4 \mathrm{~mL}$ of dry, degassed benzene over a period of $1 \mathrm{~h}$. An additional $17 \mathrm{mg}(0.1 \mathrm{mmol})$ of 
azo-bis-isobutyronitrile and $302 \mathrm{mg}(4.02 \mathrm{mmol})$ of tri-n-butylstannane in $4 \mathrm{~mL}$ of dry, degassed benzene was then added over a period of $1 \mathrm{~h}$. The mixture was warmed under reflux for $30 \mathrm{~min}$, and then concentrated in vacuo to give a pale yellow oil. The crude oil was purified by chrmomatography over $50 \mathrm{~g}$ of silica gel (eluted with hexanes-ethyl acetate, 5:1) followed by MPLC (eluted with hexanes-ethyl acetate, 6:1) to afford $5 \mathrm{mg}(2 \%)$ of trans-perhydroindan 32 as a yellow residue with tin impurities, $13 \mathrm{mg} \mathrm{(4 \% )} \mathrm{of} \mathrm{a} \mathrm{1:1} \mathrm{mixture} \mathrm{of}$ trans-perhydroindan 32 to reduction product 38a, $16 \mathrm{mg}(5 \%)$ of reduction product des-Br-22 as a yellow residue with tin impurities, and $197 \mathrm{mg}(64 \%)$ of tetracycle 32 as a white crystalline solid. The structure of the reduction product des-Br-22 is inferred from signals in the spectrum of the aforementioned fraction. Unfortunately, none of this product was isolated in its pure form. 
nOe Analysis of trans-Perhydroindan 32

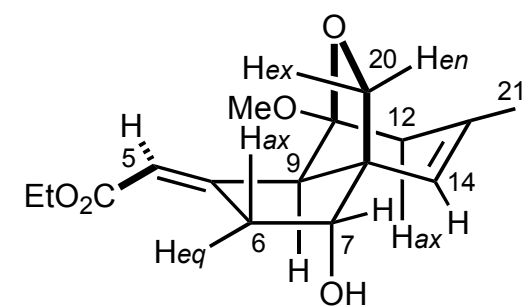

nOe Data for trans-Perhydroindan 32

\begin{tabular}{cccc} 
Proton Irradiated & $\delta(\mathbf{p p m})$ & nOe Observed & $\delta$ (ppm) \\
\hline $\mathrm{C}(5) \mathrm{H}$ & 6.89 & $\mathrm{OCH}_{3}(0.4 \%)$ & 3.27 \\
& & $\mathrm{C}(9) \mathrm{H}(0.6 \%)$ & 2.99 \\
$\mathrm{C}(14) \mathrm{H}$ & \multirow{3}{*}{5.70} & $\mathrm{C}(7) \mathrm{H}(0.8 \%)$ & 3.64 \\
& & $\mathrm{C}(20) \mathrm{H}_{e n}(0.7 \%)$ & 3.56 \\
& & $\mathrm{C}(9) \mathrm{H}(0.5 \%)$ & 2.99 \\
& & $\mathrm{C}(21) \mathrm{H}_{3}(1.8 \%)$ & 1.47 \\
$\mathrm{C}(9) \mathrm{H}$ & \multirow{3}{*}{2.99} & $\mathrm{OH}(0.6 \%)$ & 1.37 \\
& \multirow{3}{*}{2.21} & $\mathrm{C}(5) \mathrm{H}(0.6 \%)$ & 6.89 \\
$\mathrm{C}(12) \mathrm{H}_{a x}$ & $\mathrm{C}(12) \mathrm{H}_{a x}(1.4 \%)$ & 2.21 \\
& & $\mathrm{C}(9) \mathrm{H}(1.7 \%)$ & 2.99 \\
& & $\mathrm{C}(12) \mathrm{H}_{e q}(10.0 \%)$ & 2.40
\end{tabular}


nOe Analysis of Tetracycle 33

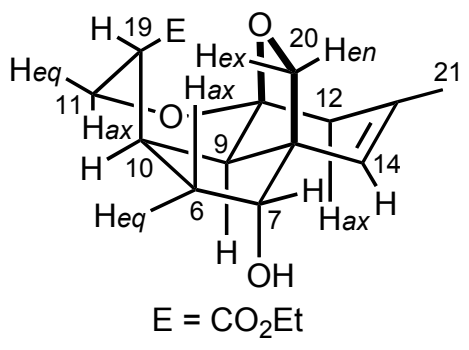

nOe Data for Tetracycle 33

\begin{tabular}{|c|c|c|c|}
\hline Proton Irradiated & $\delta(\mathrm{ppm})$ & nOe Observed & $\delta$ (ppm) \\
\hline \multirow[t]{2}{*}{$\mathrm{C}(14) \mathrm{H}$} & 6.01 & $\mathrm{C}(7) \mathrm{H}(0.6 \%)$ & 3.97 \\
\hline & & $\mathrm{C}(20) \mathrm{H}_{e n}(0.7 \%)$ & 3.74 \\
\hline \multirow[t]{2}{*}{$\mathrm{C}(11) \mathrm{H}_{\mathrm{eq}}$} & 4.71 & $\mathrm{C}(11) \mathrm{H}_{a x}(12.1 \%)$ & 3.57 \\
\hline & & $\mathrm{C}(19) \mathrm{H}(1.4 \%)$ & $2.46-2.49$ \\
\hline \multirow[t]{5}{*}{$\mathrm{C}(7) \mathrm{H}$} & 3.97 & $\mathrm{C}(14) \mathrm{H}(0.5 \%)$ & 6.01 \\
\hline & & $\mathrm{C}(20) \mathrm{H}_{e x}(1.4 \%)$ & 3.74 \\
\hline & & $\mathrm{C}(6) \mathrm{H}_{a x}(1.8 \%)$ & 3.52 \\
\hline & & $\mathrm{C}(6) \mathrm{H}_{e q}(0.8 \%)$ & 2.04 \\
\hline & & $\mathrm{OH}(1.5 \%)$ & 1.70 \\
\hline \multirow[t]{3}{*}{$\mathrm{C}(11) \mathrm{H}_{a x}$} & 3.57 & $\mathrm{C}(11) \mathrm{H}_{e q}(12.6 \%)$ & 4.71 \\
\hline & & $\mathrm{C}(10) \mathrm{H}(1.6 \%)$ & $2.60-2.66$ \\
\hline & & $\mathrm{C}(19) \mathrm{H}(2.6 \%)$ & $2.46-2.49$ \\
\hline \multirow[t]{3}{*}{$\mathrm{C}(6) \mathrm{H}_{a x}$} & 3.52 & $\mathrm{C}(7) \mathrm{H}(2.5 \%)$ & 3.97 \\
\hline & & $\mathrm{C}(20) \mathrm{H}_{e x}(4.1 \%)$ & 3.74 \\
\hline & & $\mathrm{C}(6) \mathrm{H}_{e q}(12.5 \%)$ & 2.04 \\
\hline \multirow[t]{3}{*}{$\mathrm{C}(6) \mathrm{H}_{e q}$} & 2.04 & $\mathrm{C}(7) \mathrm{H}(1.0 \%)$ & 3.97 \\
\hline & & $\mathrm{C}(6) \mathrm{H}_{a x}(11.6 \%)$ & 3.52 \\
\hline & & $\mathrm{C}(10) \mathrm{H}(2.3 \%)$ & $2.60-2.66$ \\
\hline
\end{tabular}




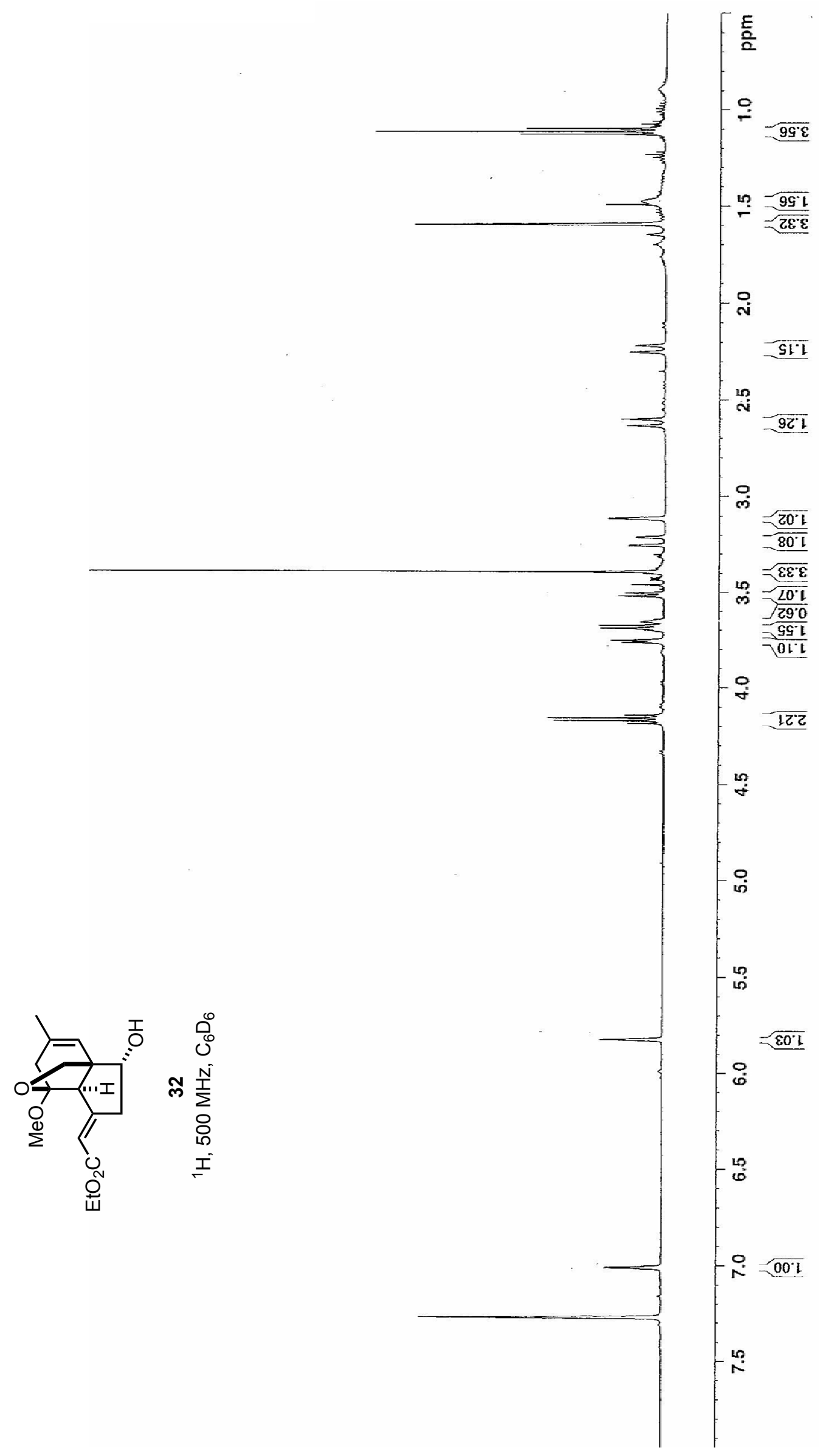




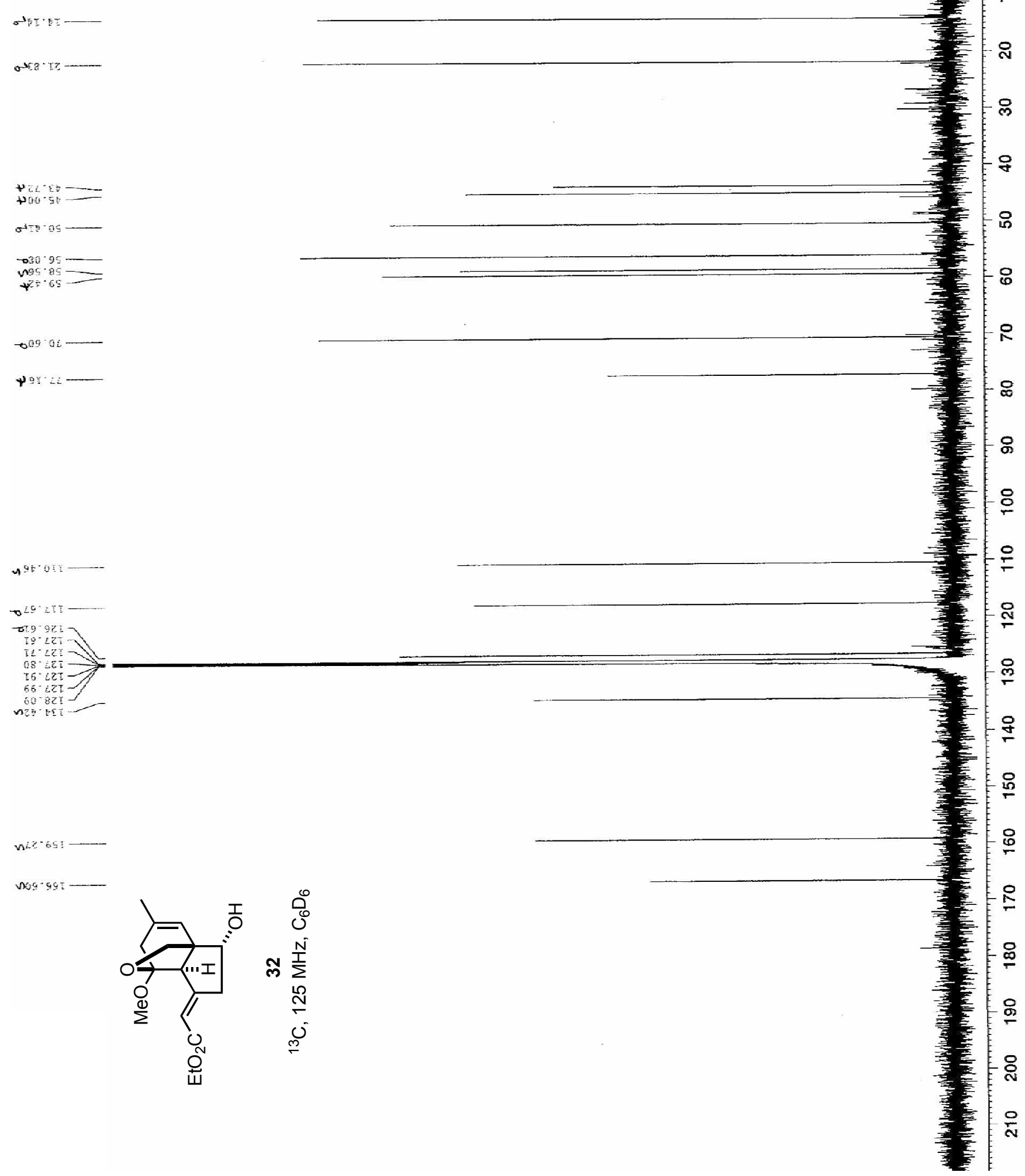




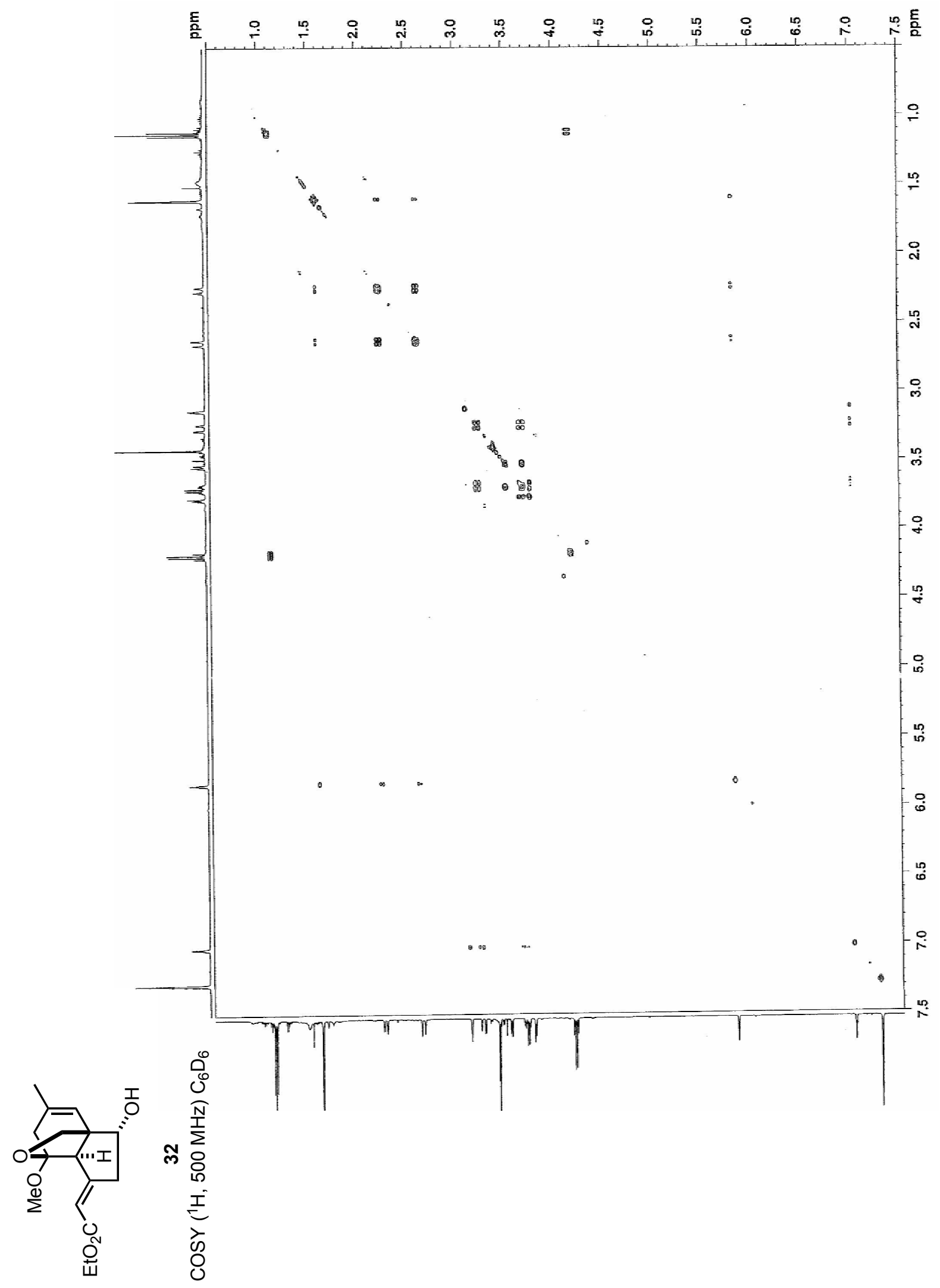




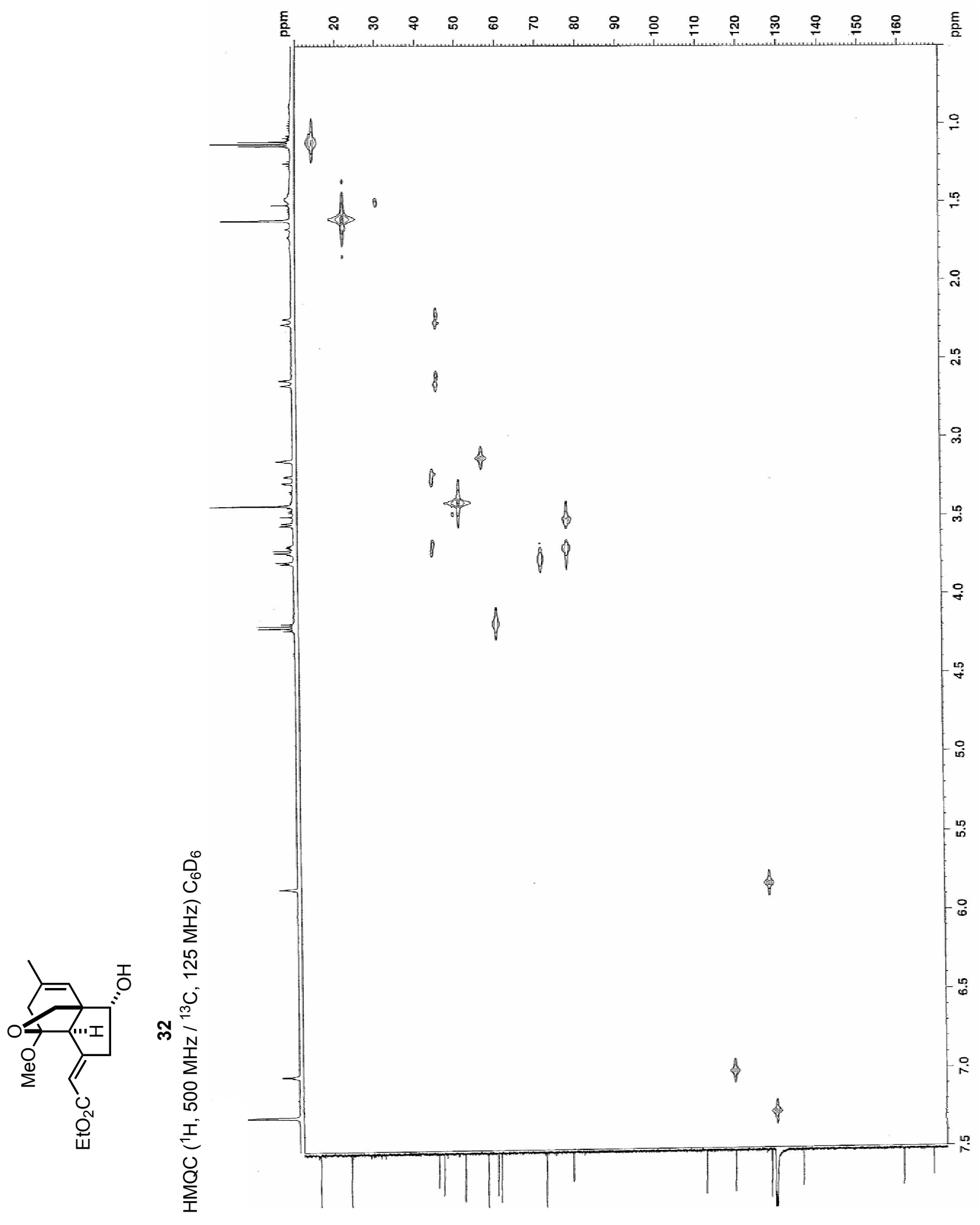




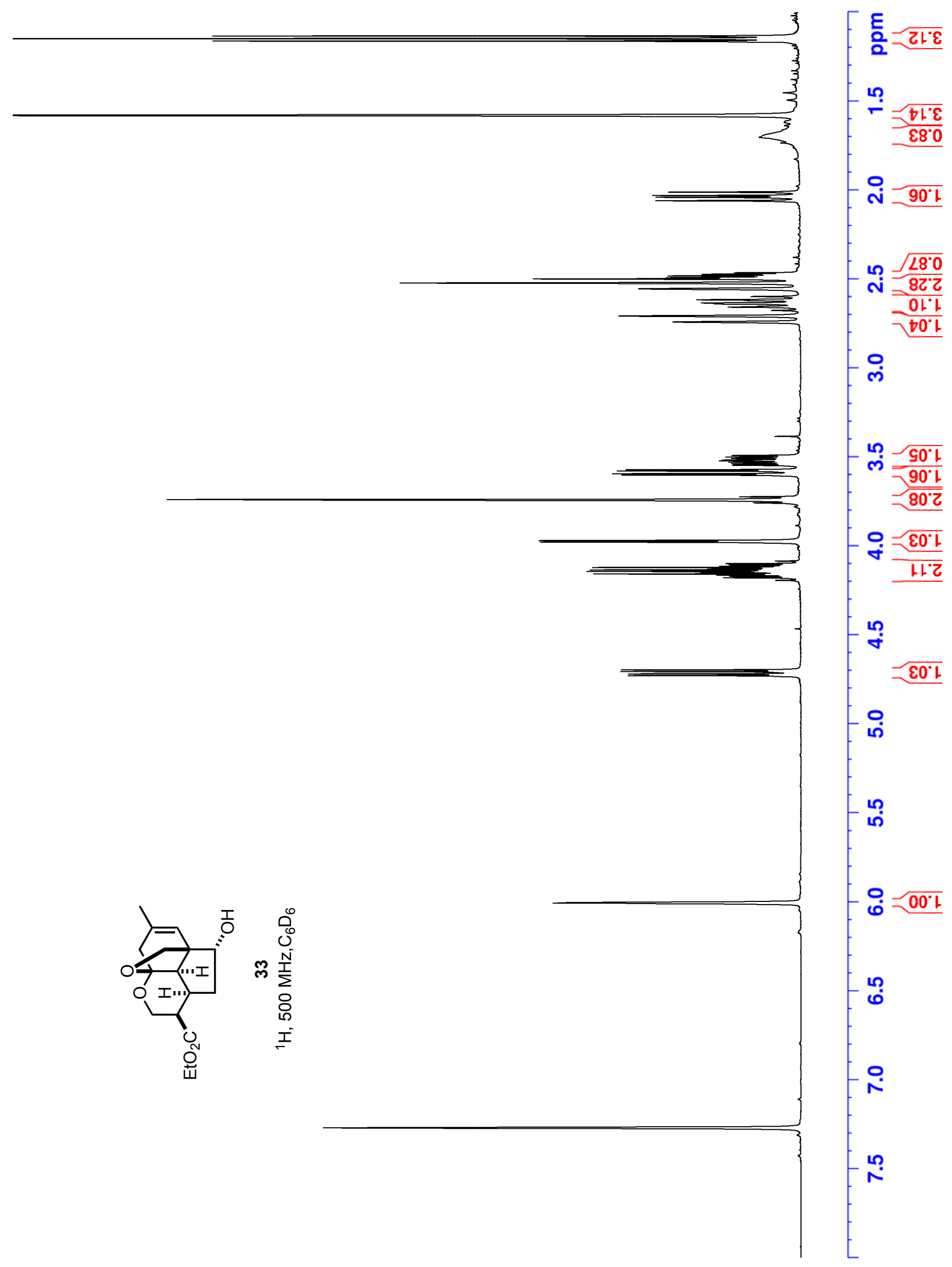









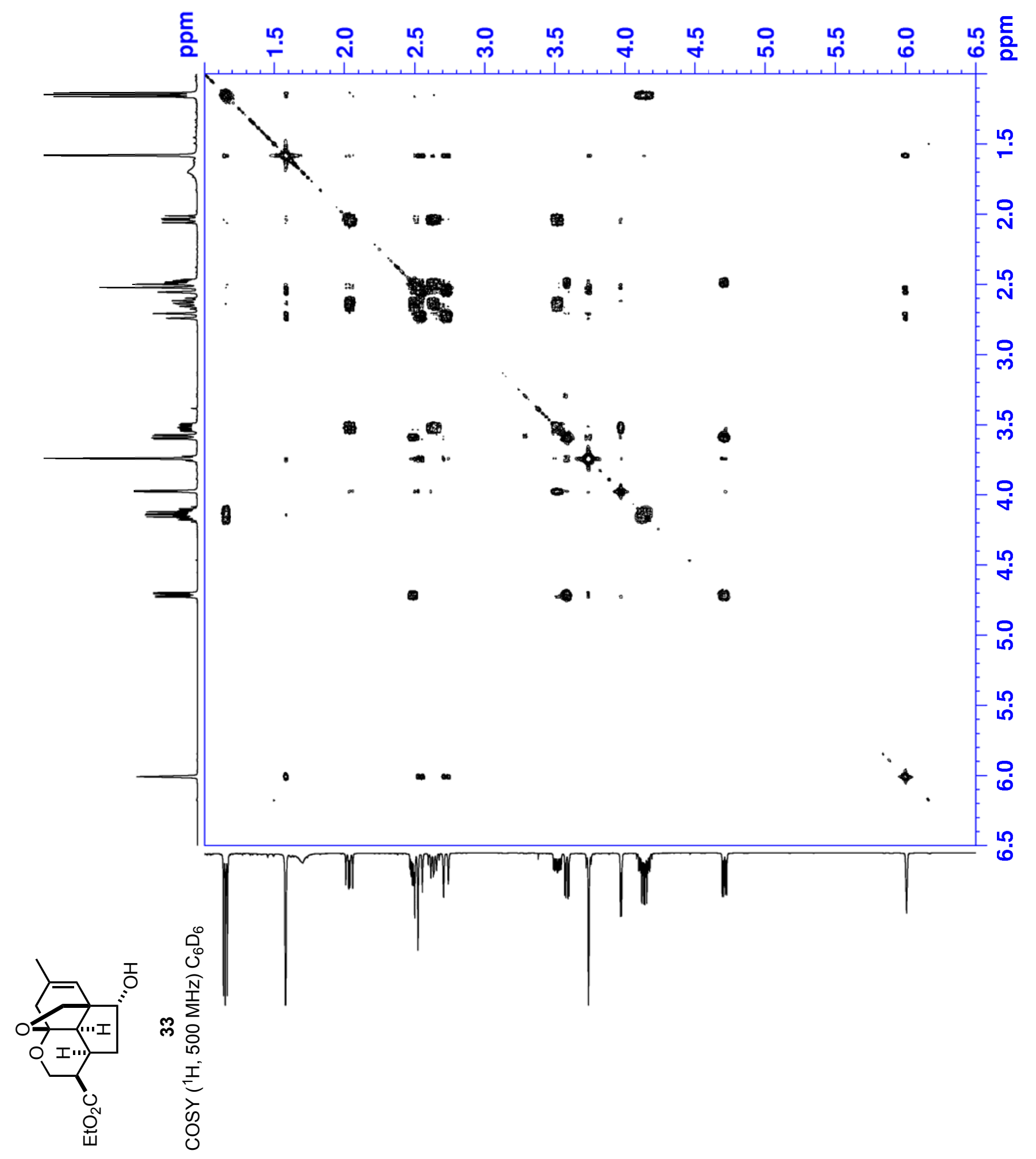




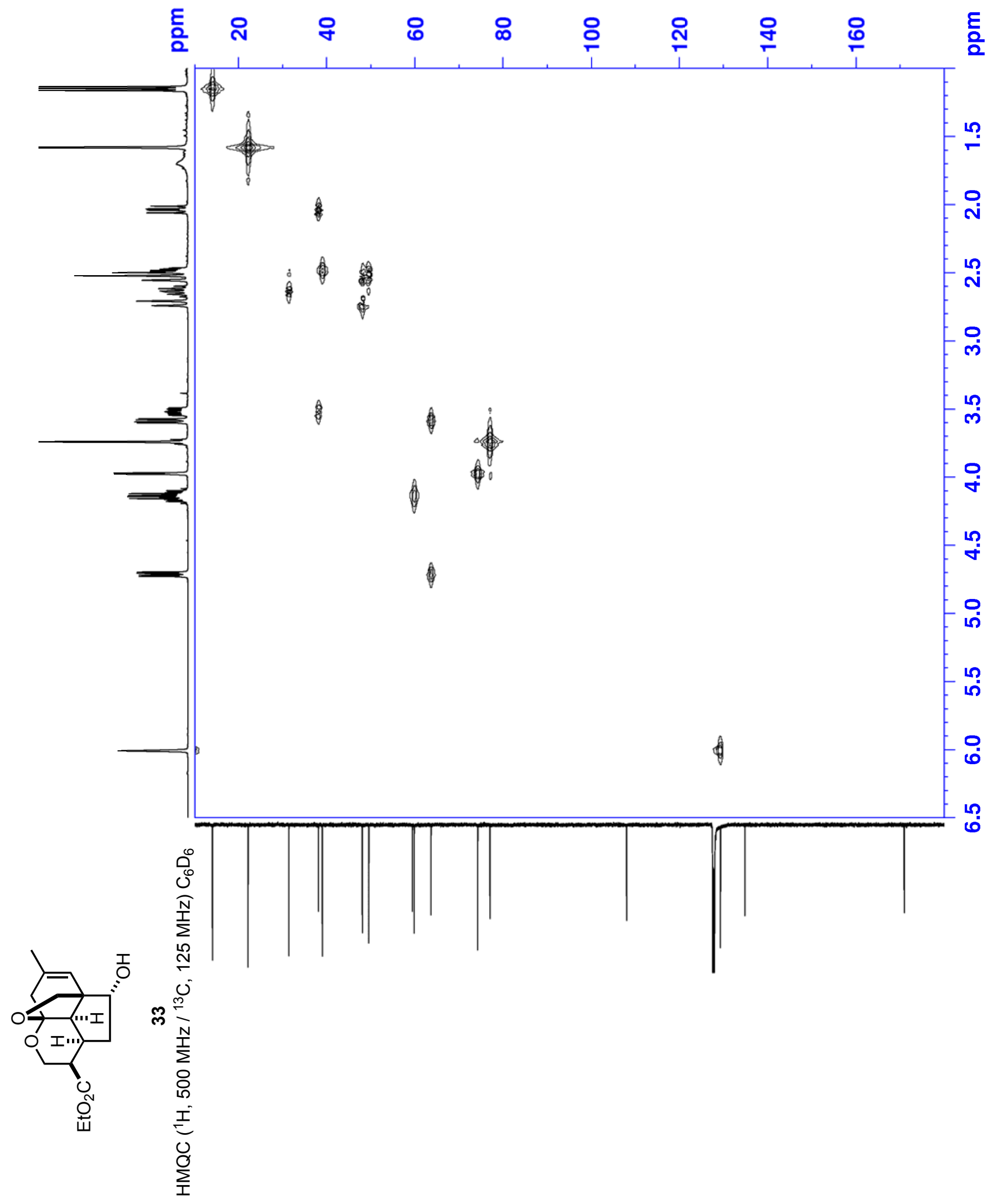




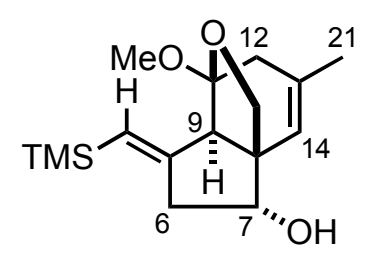

$(E)-35$

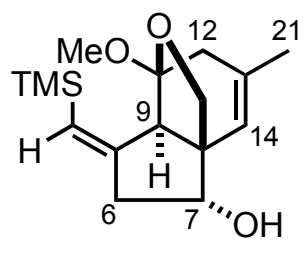

$(Z)-35$

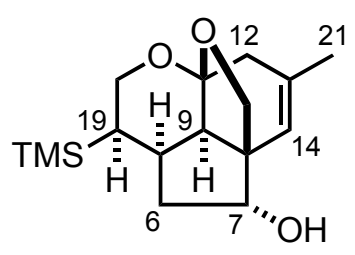

36

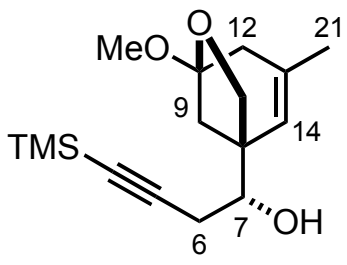

38

trans-Perhydroindan (E)-35 and trans-Perhydroindan (Z)-35 and Tetracycle 36 and Acetylene 38. A. Normal Tin Hydride Concentration: A solution of $357 \mathrm{mg}(0.957 \mathrm{mmol})$ of bromide $23,1.39 \mathrm{~g}(4.78 \mathrm{mmol})$ of tri- $n$ butyltin hydride, and $3 \mathrm{mg}(0.02 \mathrm{mmol})$ of azo-bis-isobutyronitrile in $110 \mathrm{~mL}$ of dry, degassed benzene was warmed to reflux (oil bath $110^{\circ} \mathrm{C}$ ) for $60 \mathrm{~min}$. The solvent was removed in vacuo. The residue was chromatographed over $150 \mathrm{~g}$ of silica gel (hexanes-ethyl acetate 20:1 $(1200 \mathrm{~mL}), 10: 1(440 \mathrm{~mL}), 5: 1(720 \mathrm{~mL}))$ to afford $195 \mathrm{mg}(69 \%)$ of a $5.5: 1$ inseparable mixture of reduction product 38 to trans-perhydroindans $(E)-35 /(Z)-35$ as a colorless oil. Continued elution gave 24 mg $(9 \%)$ of a $1: 5$ mixture of trans-perhydroindans $(E)-35 /(Z)-35$ to tetracycle 36 as a colorless oil. Further elution afforded $30 \mathrm{mg}(11 \%)$ of tetracycle 36 as a colorless oil that solidified upon standing at rt: $\mathrm{mp} 134-136^{\circ} \mathrm{C}$; IR (thin film) 3425 $\mathrm{cm}^{-1} ;{ }^{1} \mathrm{H}$ NMR $\left(\mathrm{C}_{6} \mathrm{D}_{6}, 500 \mathrm{MHz}\right) \delta 0.04\left(\mathrm{~s}, 9 \mathrm{H}, \mathrm{Si}^{\mathrm{t}} \mathrm{Bu}\right), 1.62-1.66(\mathrm{~m}, 1 \mathrm{H}, \mathrm{C}(19) \mathrm{H})$, $1.67\left(\mathrm{~s}, 3 \mathrm{H}, \mathrm{C}(21) \mathrm{H}_{3}\right), 1.71(\mathrm{br} s, 1 \mathrm{H}, \mathrm{OH}), 1.93(\mathrm{dd}, J=13.5,8.5 \mathrm{~Hz}, 1 \mathrm{H}$, $\left.\mathrm{C}(6) \mathrm{H}_{e q}\right), 2.16-2.22\left(\mathrm{~m}, 1 \mathrm{H}, \mathrm{C}(6) \mathrm{H}_{a x}\right), 2.63(\mathrm{~d}, J=12.0 \mathrm{~Hz}, 1 \mathrm{H}, \mathrm{C}(9) \mathrm{H}), 2.65-2.72$ (m, 1H, C(10)H), 2.77 and $2.79\left(\mathrm{AB}_{\mathrm{q}}, J=15.8 \mathrm{~Hz}, 2 \mathrm{H}, \mathrm{C}(12) \mathrm{H}_{2}\right), 3.58(\mathrm{~d}, J=7.5$ $\left.\mathrm{Hz}, 1 \mathrm{H}, \mathrm{C}(20) \mathrm{H}_{e x}\right), 3.84-3.87\left(\mathrm{~m}, 1 \mathrm{H}, \mathrm{OCH}_{e q}\right), 3.89(\mathrm{~d}, J=3.5 \mathrm{~Hz}, 1 \mathrm{H}, \mathrm{C}(7) \mathrm{H})$, 
$3.94\left(\mathrm{~d}, J=7.5 \mathrm{~Hz}, 1 \mathrm{H}, \mathrm{C}(20) \mathrm{H}_{e n}\right), 4.49\left(\mathrm{dd}, J=13.7,11.7 \mathrm{~Hz}, 1 \mathrm{H}, \mathrm{OCH}_{a x}\right), 6.15$ $(\mathrm{m}, 1 \mathrm{H}, \mathrm{C}(14) \mathrm{H}) ;{ }^{13} \mathrm{C} \operatorname{NMR}\left(\mathrm{C}_{6} \mathrm{D}_{6}, 125 \mathrm{MHz}\right) \delta-1.7$ (q), 22.6 (q), 24.0 (d), 27.0 (d), $40.1(t), 49.1(d), 49.4(t), 59.6(s), 59.7(t), 73.8(d), 80.3(t), 108.4(s), 129.7(d)$ 135.7 (s); exact mass calcd. for $\mathrm{C}_{16} \mathrm{H}_{26} \mathrm{O}_{3} \mathrm{Si}(\mathrm{M}+\mathrm{Na})^{+} \mathrm{m} / \mathrm{z} 317.1549$, found $\mathrm{m} / \mathrm{z}$ 317.1558. Anal. calcd. for $\mathrm{C}_{16} \mathrm{H}_{26} \mathrm{O}_{3} \mathrm{Si}: \mathrm{C}, 65.26 ; \mathrm{H}, 8.90$. Found: $\mathrm{C}, 65.47 ; \mathrm{H}$, 8.97.

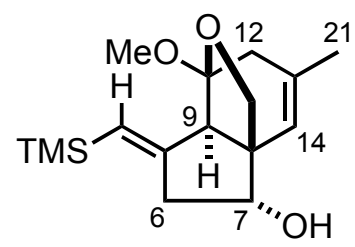

$(E)-35$

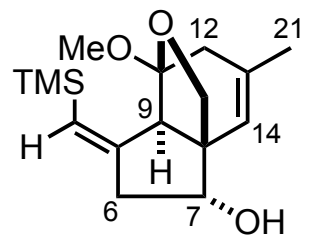

$(Z)-35$

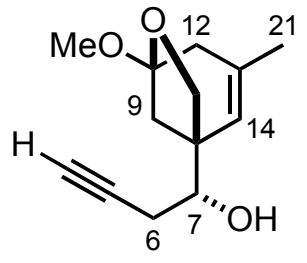

38

trans-Perhydroindan (E)-36, trans-Perhydroindan $(Z)-36$, and Acetylene 38 . To a solution of $37 \mathrm{mg}(0.13 \mathrm{mmol})$ of an $84: 16$ mixture of 38 to $(E)-35 /(Z)-35$ in $3 \mathrm{~mL}$ of dry tetrahydrofuran was added $130 \mu \mathrm{L}(0.13 \mathrm{mmol})$ of tetra- $n$-butylammonium fluoride (1.0 $\mathrm{M}$ in tetrahydrofuran). Thin layer analysis (silica gel, hexanes-ethyl acetate, 1:1) showed starting material and a more polar spot after 2 min. The solvent was removed in vacuo. The residue was chromatographed over $25 \mathrm{~g}$ of silica gel (hexanes-ethyl acetate, 10:1) to give 6.0 $\mathrm{mg}(100 \%$ recovery) of a 3.1 to 1 inseparable mixture of trans-perhydroindans (E)-35 to (Z)-35 as a colorless oil that solidified upon standing at rt: $\mathrm{mp} 121$ $144^{\circ} \mathrm{C}$; data for the major isomer $(E)-35:{ }^{1} \mathrm{H}$ NMR $\left(\mathrm{C}_{6} \mathrm{D}_{6}, 500 \mathrm{MHz}\right) \delta 0.28(\mathrm{~s}, 9 \mathrm{H}$, $\left.\mathrm{Si}\left(\mathrm{CH}_{3}\right)_{3}\right), 1.62\left(\mathrm{~s}, 3 \mathrm{H}, \mathrm{C}(21) \mathrm{H}_{3}\right), 2.42,2.58\left(\mathrm{AB}_{\mathrm{q}}, J=16.4 \mathrm{~Hz}, 2 \mathrm{H}, \mathrm{C}(12) \mathrm{H}_{2}\right), 2.54$ (d, $\left.J=18.3 \mathrm{~Hz}, 1 \mathrm{H}, \mathrm{C}(6) \mathrm{H}_{\mathrm{eq}}\right), 2.95-3.00\left(\mathrm{~m}, 1 \mathrm{H}, \mathrm{C}(6) \mathrm{H}_{a x}\right), 3.02(\mathrm{~s}, 1 \mathrm{H}, \mathrm{C}(9) \mathrm{H})$, 
$3.48\left(\mathrm{~s}, 3 \mathrm{H}, \mathrm{OCH}_{3}\right), 3.64(\mathrm{~d}, J=8.0 \mathrm{~Hz}, 1 \mathrm{H}, \mathrm{C}(20) \mathrm{H}), 3.73-3.76(\mathrm{~m}, 2 \mathrm{H}, \mathrm{C}(7) \mathrm{H}$, $\mathrm{C}(20) \mathrm{H}), 5.78(\mathrm{~s}, 1 \mathrm{H}, \mathrm{C}(14) \mathrm{H}), 6.69(\mathrm{~s}, 1 \mathrm{H}, \mathrm{C}(5) \mathrm{H})$, the hydroxyl proton was not recorded; ${ }^{13} \mathrm{C}$ NMR $\left(\mathrm{C}_{6} \mathrm{D}_{6}, 125 \mathrm{MHz}\right) \delta-0.5(\mathrm{q}), 22.0(\mathrm{q}), 43.3(\mathrm{t}), 45.4(\mathrm{t}), 50.6$ (q), $56.0(\mathrm{~d}), 59.0(\mathrm{~s}), 70.7(\mathrm{~d}), 77.2(\mathrm{t}), 111.1(\mathrm{~s}), 125.8(\mathrm{~d}), 126.4(\mathrm{~d}), 134.8(\mathrm{~s})$, 154.2 (s); data for the minor isomer (Z)-36: ${ }^{1} \mathrm{H} \operatorname{NMR}\left(\mathrm{C}_{6} \mathrm{D}_{6}, 500 \mathrm{MHz}\right) \delta 0.40(\mathrm{~s}$, $\left.9 \mathrm{H}, \mathrm{Si}\left(\mathrm{CH}_{3}\right)_{3}\right), 1.62\left(\mathrm{~s}, 3 \mathrm{H}, \mathrm{C}(21) \mathrm{H}_{3}\right), 2.43,2.61\left(\mathrm{AB}_{\mathrm{q}}, J=16.5 \mathrm{~Hz}, 2 \mathrm{H}, \mathrm{C}(12) \mathrm{H}_{2}\right)$, $2.42\left(\mathrm{~d}, J=18.0 \mathrm{~Hz}, 1 \mathrm{H}, \mathrm{C}(6) \mathrm{H}_{e q}\right), 3.03-3.10\left(\mathrm{~m}, 1 \mathrm{H}, \mathrm{C}(6) \mathrm{H}_{a x}\right), 3.17(\mathrm{~s}, 1 \mathrm{H}$, $\mathrm{C}(9) \mathrm{H}), 3.45\left(\mathrm{~s}, 3 \mathrm{H}, \mathrm{OCH}_{3}\right), 3.61(\mathrm{~d}, J=5.0 \mathrm{~Hz}, 1 \mathrm{H}, \mathrm{C}(7) \mathrm{H}), 3.61-3.64(\mathrm{~m}, 1 \mathrm{H}$, $\mathrm{C}(20) \mathrm{H}), 3.73-3.76(\mathrm{~m}, 1 \mathrm{H}, \mathrm{C}(20) \mathrm{H}), 5.86(\mathrm{~s}, 1 \mathrm{H}, \mathrm{C}(14) \mathrm{H}), 5.91(\mathrm{~s}, 1 \mathrm{H}, \mathrm{C}(5) \mathrm{H})$, the hydroxyl proton was not recorded; ${ }^{13} \mathrm{C}$ NMR $\left(\mathrm{C}_{6} \mathrm{D}_{6}, 125 \mathrm{MHz}\right) \delta 0.1$ (q), 21.9 (q), $45.9(\mathrm{t}), 47.9(\mathrm{t}), 49.8(\mathrm{q}), 55.7(\mathrm{~d}), 61.2(\mathrm{~s}), 70.7(\mathrm{~d}), 77.5(\mathrm{t}), 110.7(\mathrm{~s}), 125.8$ (d), 126.4 (d), 134.6 (s), 152.9 (s); exact mass calcd. for $\mathrm{C}_{16} \mathrm{H}_{26} \mathrm{O}_{3} \mathrm{Si}(\mathrm{M}+\mathrm{Na})^{+} \mathrm{m} / \mathrm{z}$ submitted

Continued elution (hexanes-ethyl acetate, 10:1) gave $16 \mathrm{mg}(70 \%)$ of terminal alkyne 38 as a colorless oil: ${ }^{1} \mathrm{H}$ NMR $\left(\mathrm{C}_{6} \mathrm{D}_{6}, 500 \mathrm{MHz}\right) \delta 1.28(\mathrm{~d}, J=10.1$ $\mathrm{Hz}, 1 \mathrm{H}, \mathrm{C}(9) \mathrm{H}), 1.47$ (br s, 1H, OH), $1.58\left(\mathrm{~s}, 3 \mathrm{H}, \mathrm{C}(21) \mathrm{H}_{3}\right), 1.83(\mathrm{t}, J=2.6 \mathrm{~Hz}$, $1 \mathrm{H}, \equiv \mathrm{CH}), 1.88(\mathrm{~d}, J=10.2 \mathrm{~Hz}, 1 \mathrm{H}, \mathrm{C}(9) \mathrm{H}), 2.10(\mathrm{dt}, J=16.7,3.1 \mathrm{~Hz}, 1 \mathrm{H}$, $\mathrm{C}(6) \mathrm{H}), 2.24$ (ddd, $J=16.8,9.5,2.6 \mathrm{~Hz}, 1 \mathrm{H}, \mathrm{C}(6) \mathrm{H}), 2.48,2.53\left(\mathrm{AB}_{\mathrm{q}}, J=16.9 \mathrm{~Hz}\right.$, $\left.2 \mathrm{H}, \mathrm{C}(12) \mathrm{H}_{2}\right), 3.42\left(\mathrm{~s}, 3 \mathrm{H}, \mathrm{OCH}_{3}\right), 3.53(\mathrm{dd}, J=9.5,3.7 \mathrm{~Hz}, 1 \mathrm{H}, \mathrm{C}(7) \mathrm{H}), 3.90(\mathrm{~d}$, $J=6.7 \mathrm{~Hz}, 1 \mathrm{H}, \mathrm{C}(20) \mathrm{H}), 4.21(\mathrm{dd}, J=6.8,1.0 \mathrm{~Hz}, 1 \mathrm{H}, \mathrm{C}(20) \mathrm{H}), 5.80(\mathrm{~s}, 1 \mathrm{H}$, $\mathrm{C}(14) \mathrm{H}) ;{ }^{13} \mathrm{C}$ NMR $\left(\mathrm{C}_{6} \mathrm{D}_{6}, 125 \mathrm{MHz}\right) \delta 22.1(\mathrm{q}), 24.6(\mathrm{t}), 38.1(\mathrm{t}), 45.7(\mathrm{t}), 48.9(\mathrm{q})$, $50.4(\mathrm{~s}), 71.0$ (d), 72.6 (d), 79.8 (t), 81.1 (s), 108.8 (s), 124.3 (d), 135.2 (s); exact 
mass calcd. for $\mathrm{C}_{13} \mathrm{H}_{18} \mathrm{O}_{3}(\mathrm{M}+\mathrm{Na})^{+} \mathrm{m} / \mathrm{z}$ 245.1154, found $\mathrm{m} / \mathrm{z}$ 245.1152. Anal. calcd. for $\mathrm{C}_{13} \mathrm{H}_{18} \mathrm{O}_{3} \mathrm{C}, 70.24 ; \mathrm{H}, 8.16$. Found: $\mathrm{C}, 70.23 ; \mathrm{H}, 8.42$.

B. Low Tin Hydride Concentration: A solution of $85 \mathrm{mg}(0.23 \mathrm{mmol})$ of bromide 23, $2 \mathrm{mg}(0.01 \mathrm{mmol})$ of azo-bis-isobutyronitrile, and $66 \mathrm{mg}(0.23 \mathrm{mmol})$ of tri-n-butylstannane in $25 \mathrm{~mL}$ of dry, degassed benzene was warmed under reflux for $1 \mathrm{~h}$, and then concentrated in vacuo to give a pale yellow oil. The crude oil was purified by chrmomatography over $25 \mathrm{~g}$ of silica gel (eluted with hexanesethyl acetate, $20: 1 \rightarrow 10: 1 \rightarrow 5: 1 \rightarrow 2: 1)$ to afford $6.3 \mathrm{mg}(9 \%)$ of a $5.6: 1.8: 1$ mixture of 38 to $(E)-35$ to $(Z)-35$ as a colorles residue, and $42 \mathrm{mg}(63 \%)$ of tetracycle $\mathbf{3 6}$ as a white crystalline solid. 
nOe Analysis of Tetracycle 36

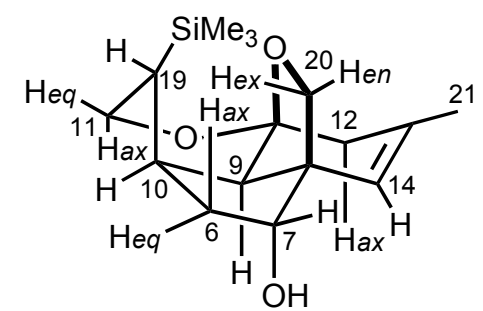

Proton Irradiated $\quad$ NOE

$\mathrm{H}_{14}(6.15 \mathrm{ppm}) \quad \mathrm{H}_{20 \text { en }}(0.6 \%), \mathrm{H}_{7}(0.6 \%), \mathrm{H}_{21}(1.7 \%)$

$\mathrm{H}_{11 \text { ax }}(4.49 \mathrm{ppm}) \quad \mathrm{H}_{11 \text { eq }}(1.0 \%), \mathrm{C}_{6 \text { ax }}(0.6 \%), \mathrm{Si}\left(\mathrm{CH}_{3}\right)_{3}(1.8 \%)$

$\mathrm{H}_{20 \text { en }}(3.94 \mathrm{ppm}) \quad \mathrm{H}_{14}(0.9 \%), \mathrm{H}_{20 \text { ex }}(13.8 \%)$

$\mathrm{H}_{20 \text { ex }}(3.58 \mathrm{ppm}) \quad \mathrm{H}_{11 \text { ax }}(0.8 \%), \mathrm{H}_{20}$ en $(15.6 \%), \mathrm{H}_{6 \text { ax }}(6.4 \%), \mathrm{Si}\left(\mathrm{CH}_{3}\right)_{3}(0.5 \%)$

$\mathrm{H}_{12 \text { ax }}(2.77 \mathrm{ppm}) \quad \mathrm{H}_{14}(1.2 \%), \mathrm{H}_{9}(2.0 \%), \mathrm{H}_{21}(2.7 \%)$

$\mathrm{H}_{6 \mathrm{ax}}(2.16-2.22 \mathrm{ppm}) \quad \mathrm{H}_{11 \text { ax }}(0.6 \%), \mathrm{H}_{7}(2.6 \%), \mathrm{H}_{20 \text { ex }}(6.6 \%), \mathrm{H}_{6 \text { eq }}(9.9 \%), \mathrm{Si}\left(\mathrm{CH}_{3}\right)_{3}$

$(2.5 \%)$

$\mathrm{H}_{6 \text { eq }}(1.93 \mathrm{ppm}) \quad \mathrm{H}_{7}(1.4 \%), \mathrm{H}_{10}(2.0 \%), \mathrm{H}_{9}(0.5 \%), \mathrm{H}_{6 \text { ax }}(8.5 \%), \mathrm{OH}(0.7 \%)$,

$\mathrm{Si}\left(\mathrm{CH}_{3}\right)_{3}(2.1 \%)$

$\mathrm{H}_{19}(1.62-1.66 \mathrm{ppm}) \quad \mathrm{H}_{11 \text { ax }}(0.7 \%), \mathrm{H}_{11 \text { eq }}(2.0 \%), \mathrm{H}_{10}(3.3 \%), \mathrm{H}_{9}(1.2 \%), \mathrm{Si}\left(\mathrm{CH}_{3}\right)_{3}(1.4 \%)$

$\mathrm{Si}\left(\mathrm{CH}_{3}\right)_{3}(0.10 \mathrm{ppm}) \quad \mathrm{H}_{11 \text { ax }}(3.4 \%), \mathrm{H}_{11 \text { eq }}(3.7 \%), \mathrm{H}_{20 \text { ex }}(1.7 \%), \mathrm{H}_{10}(3.2 \%), \mathrm{H}_{9}(1.3 \%)$

$\mathrm{H}_{6 \mathrm{ax}}(4.6 \%), \mathrm{H}_{6 \text { eq }}(3.7 \%), \mathrm{H}_{19}(3.9 \%)$ 


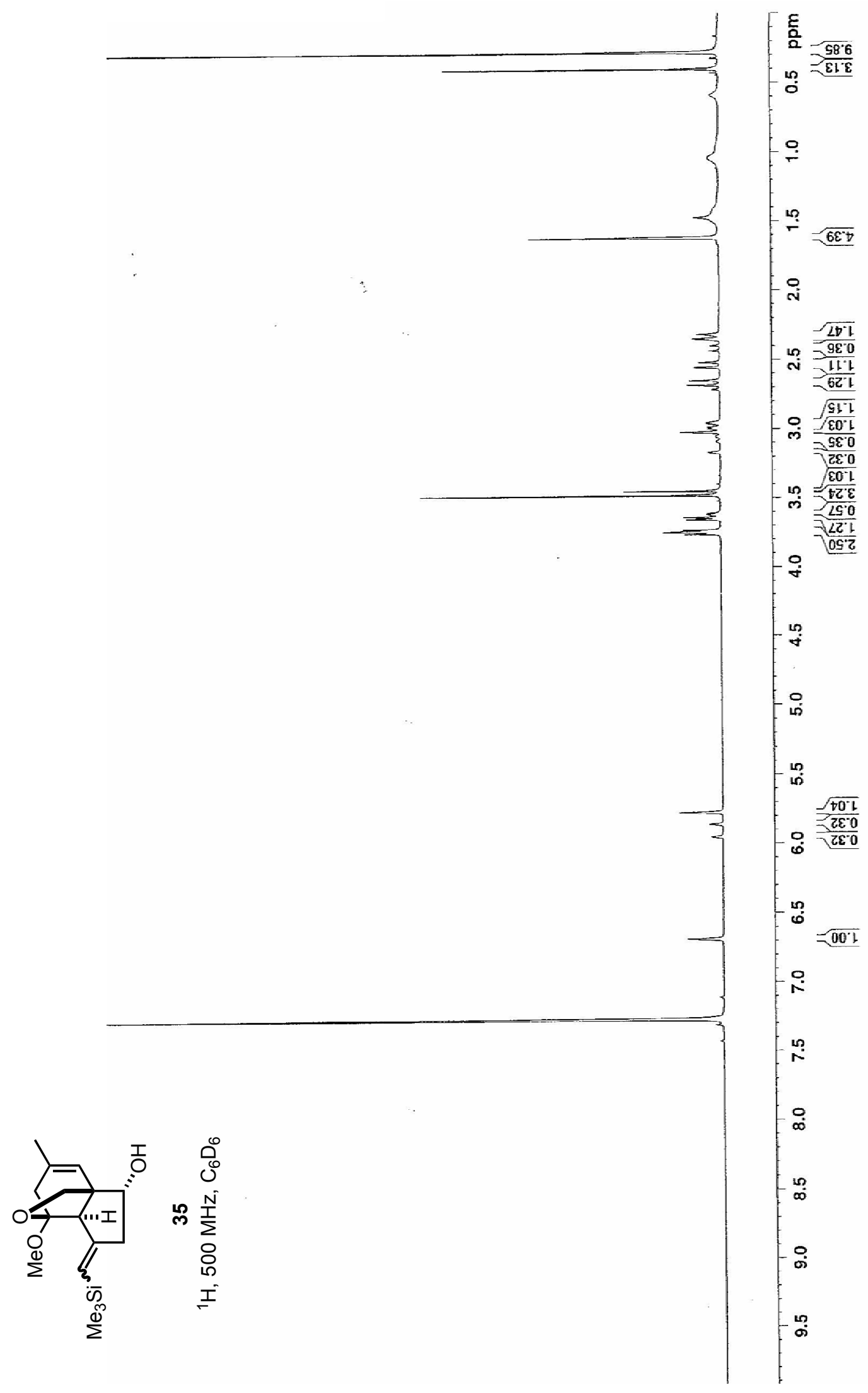




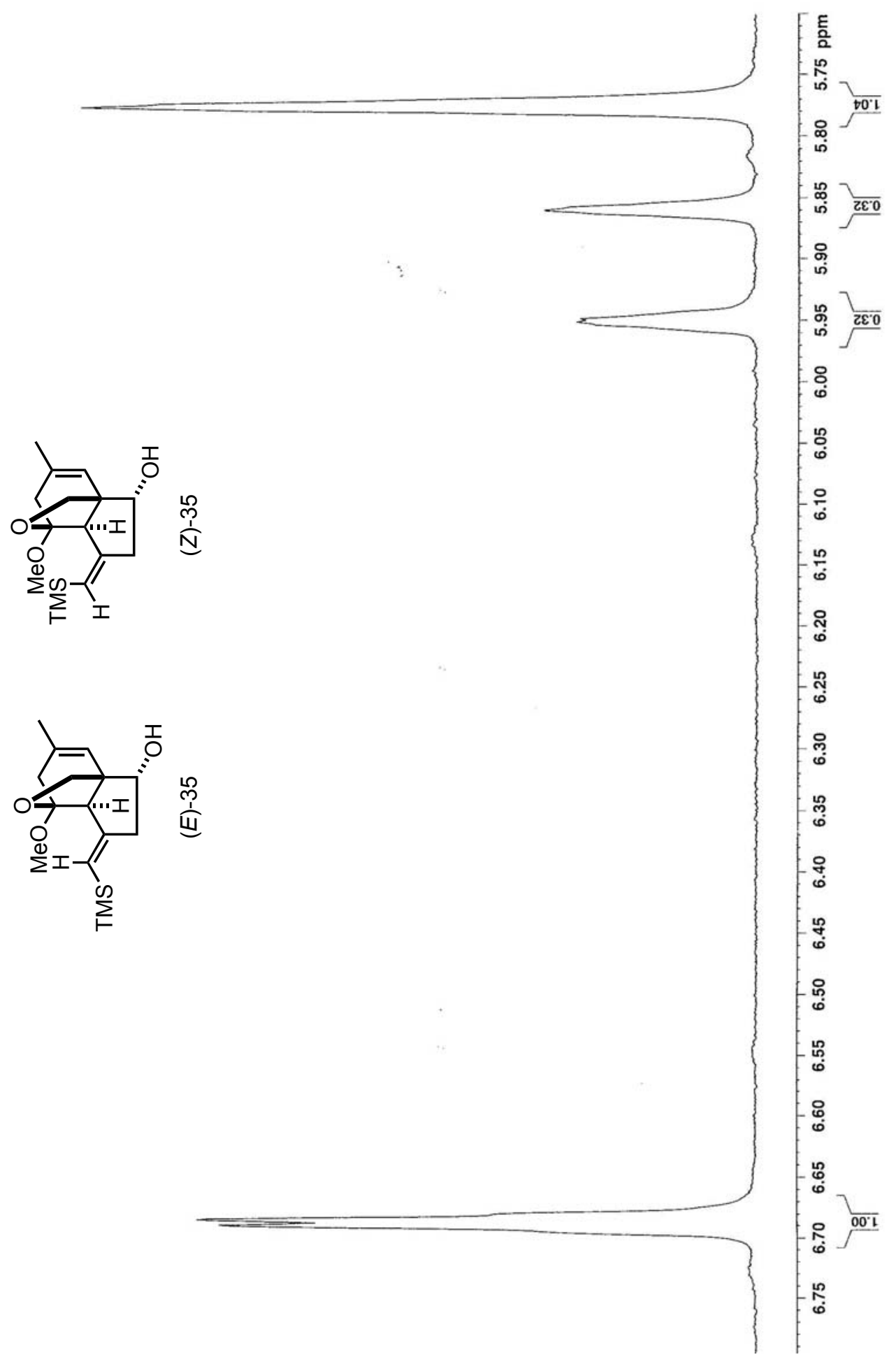




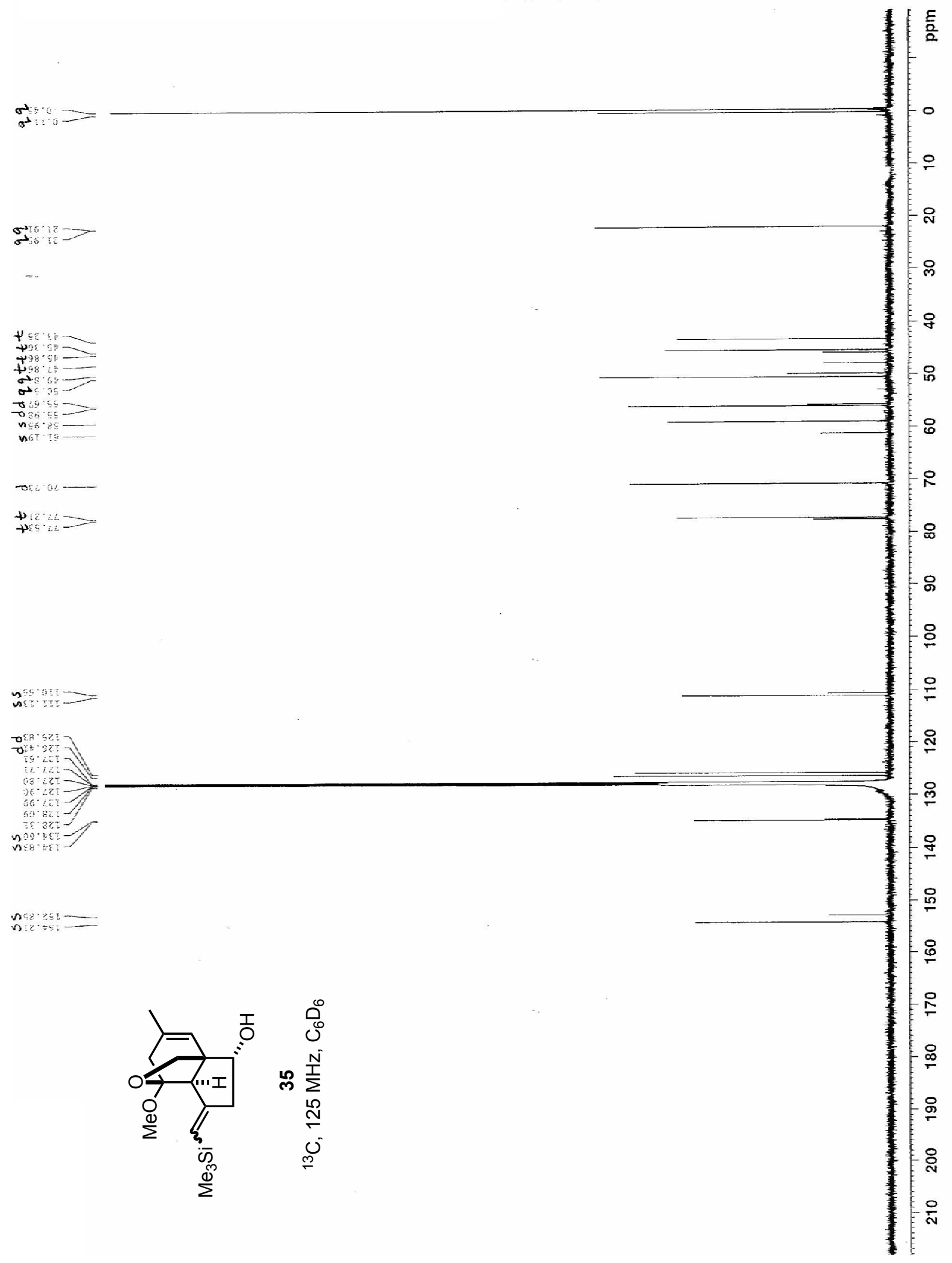




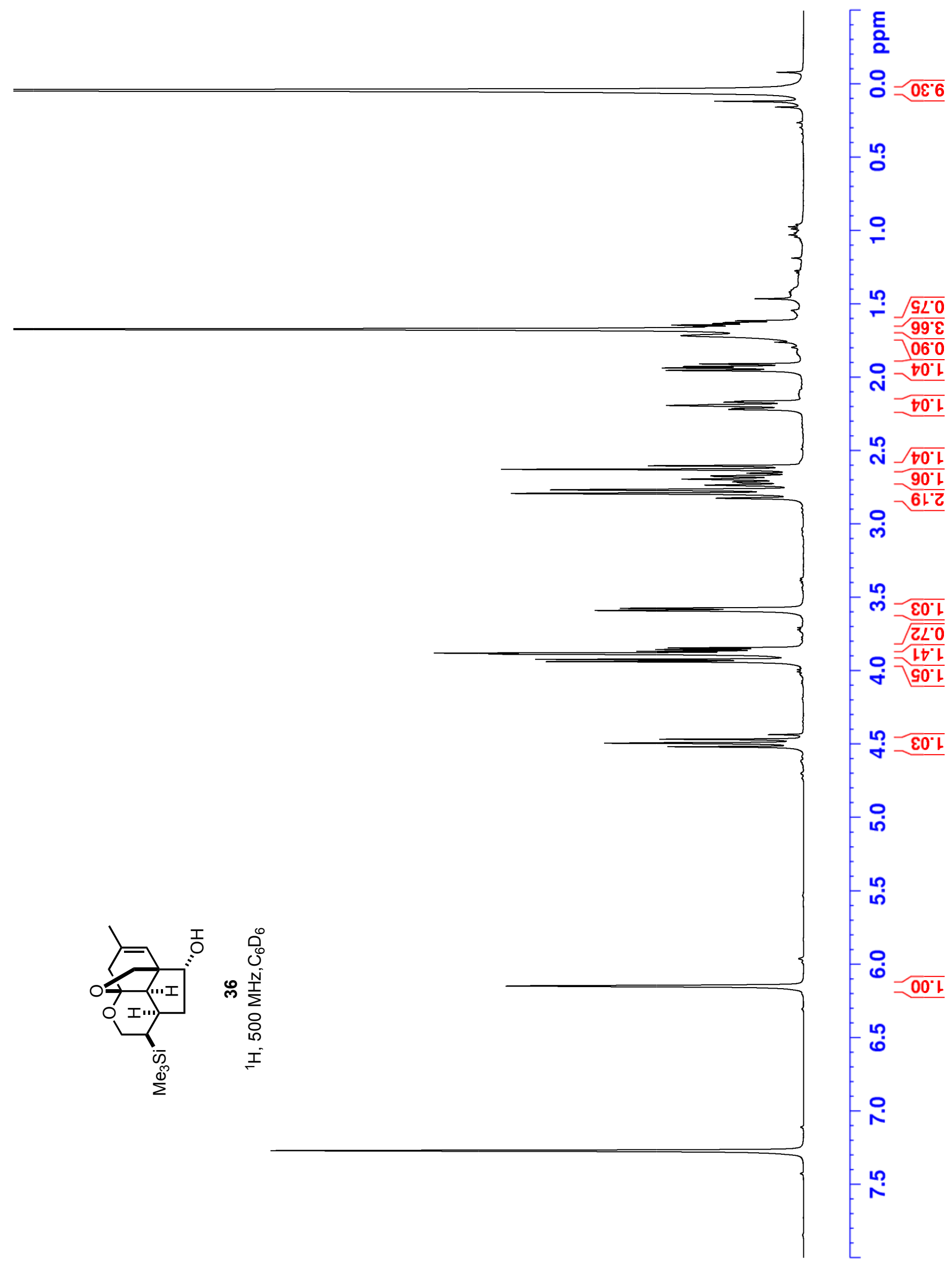




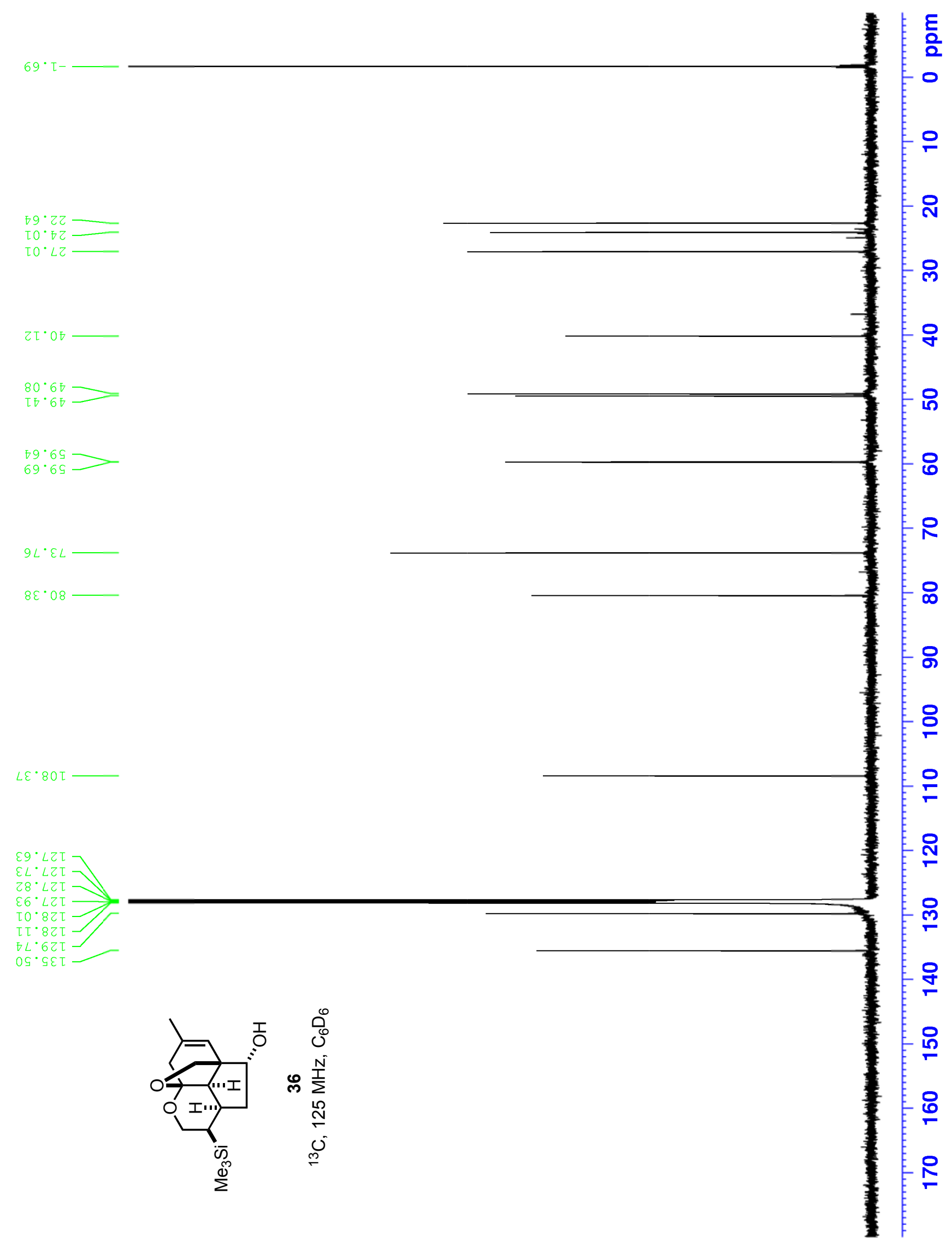




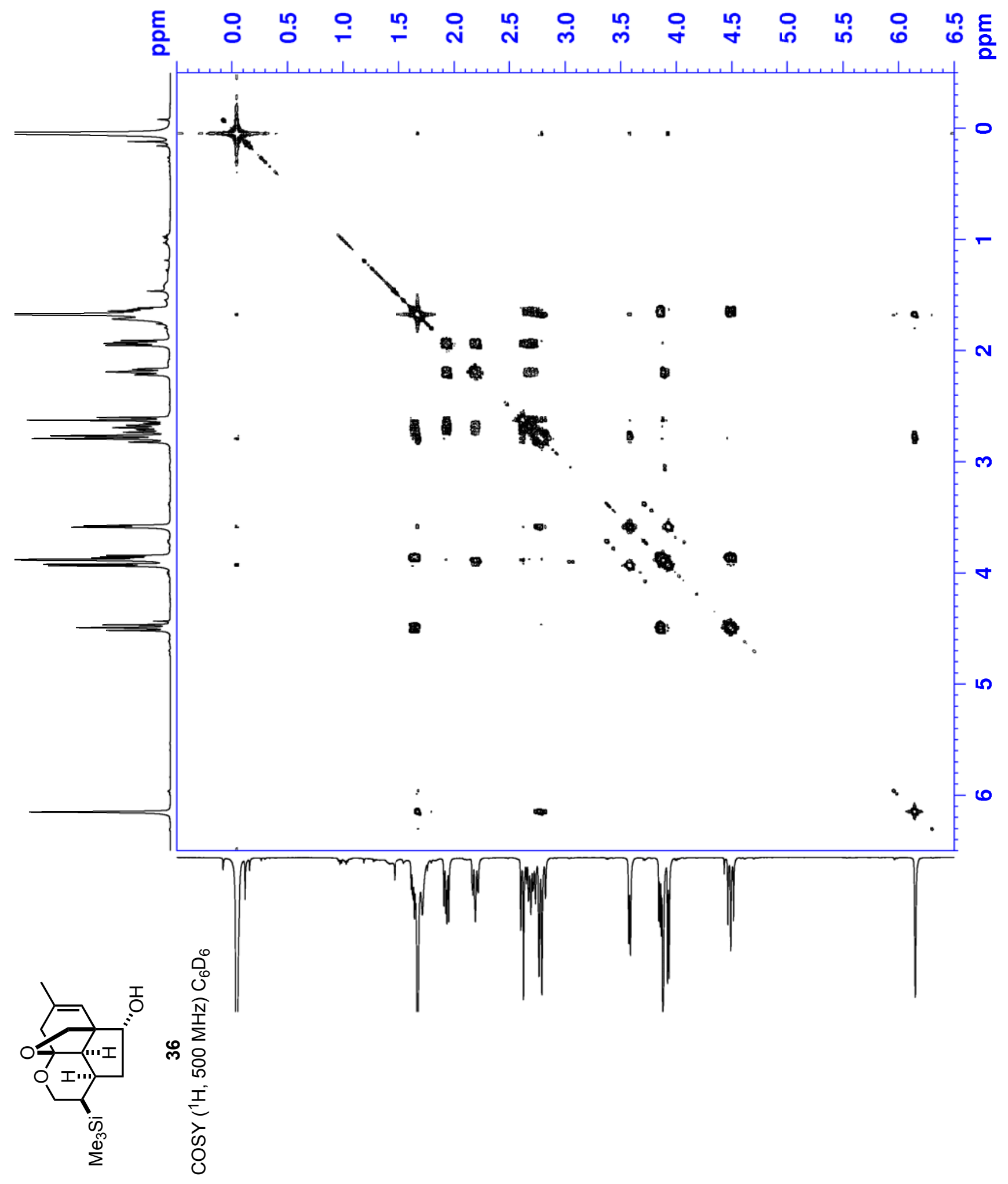




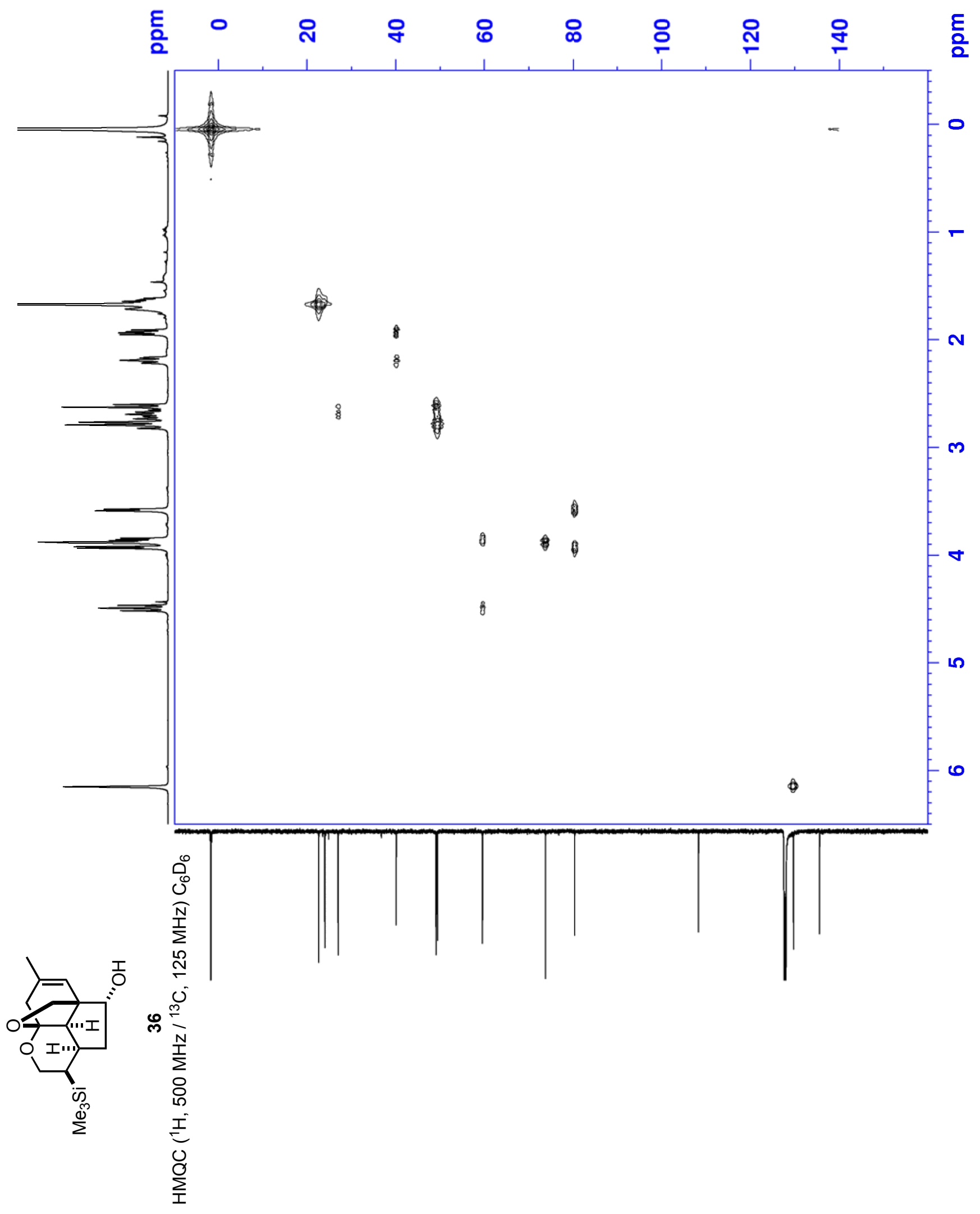




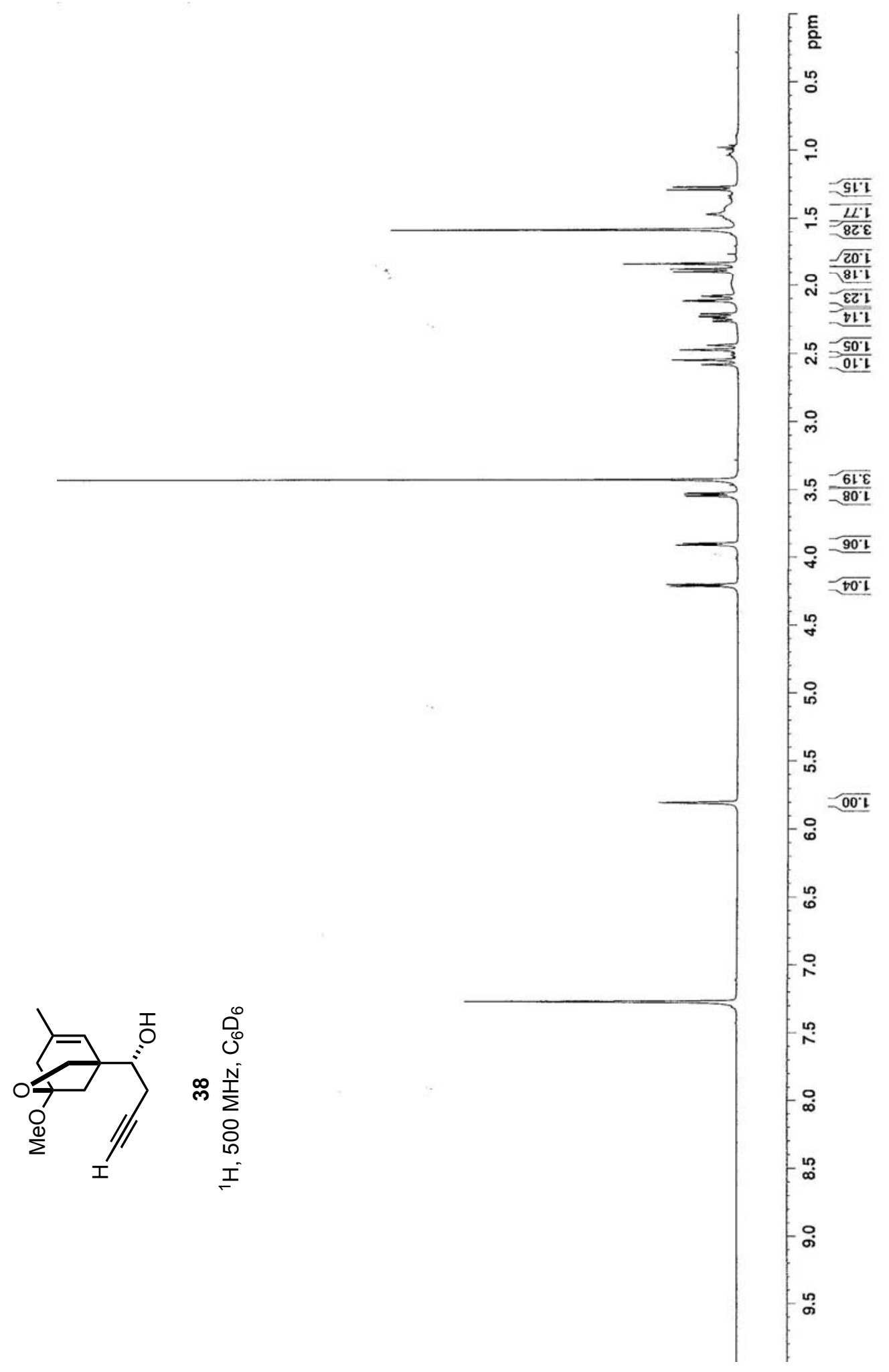




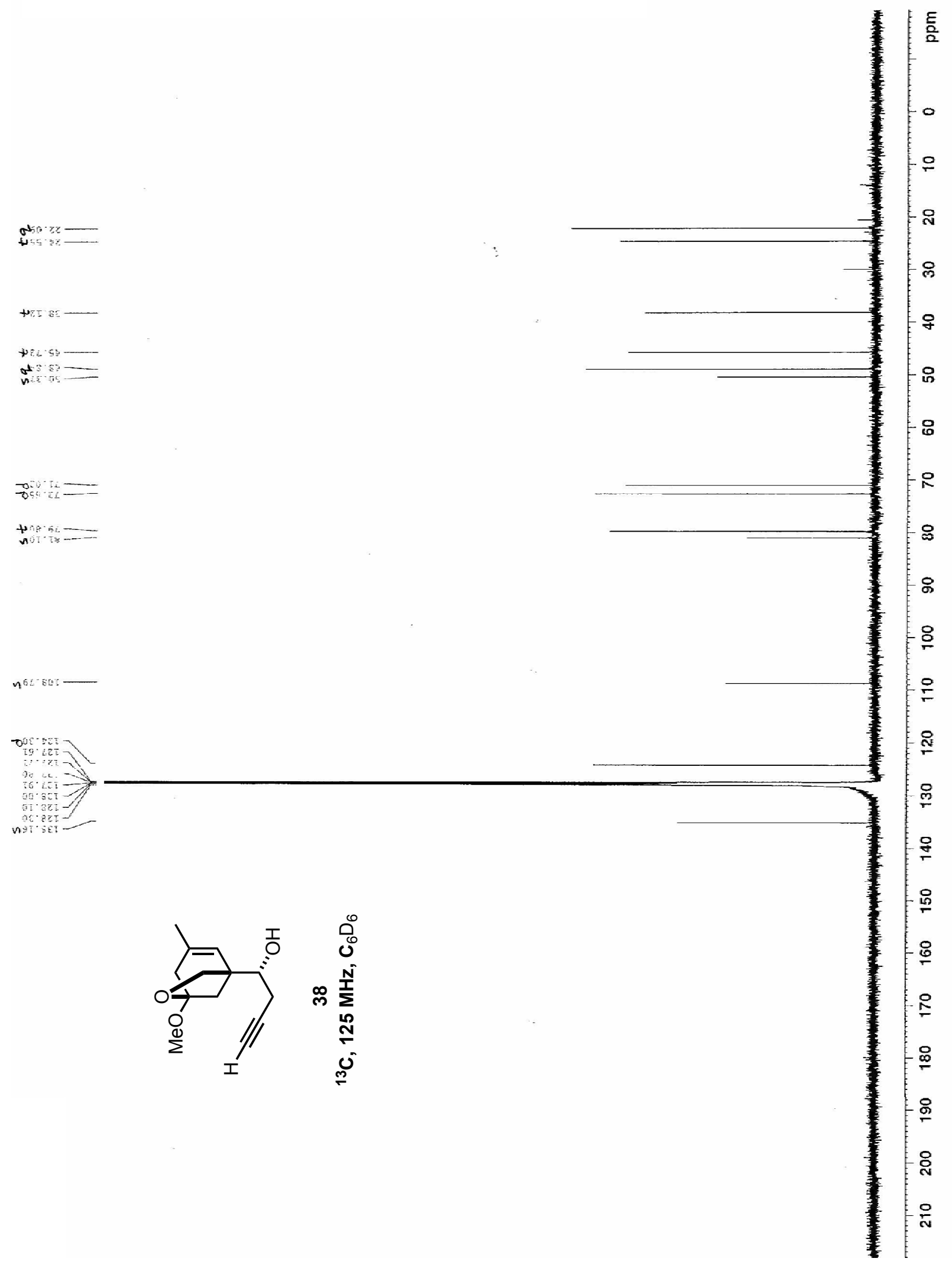




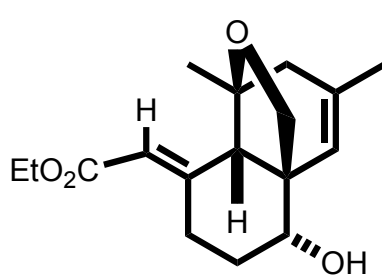

39

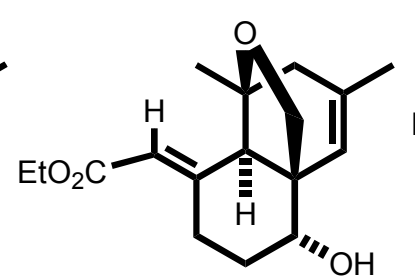

40

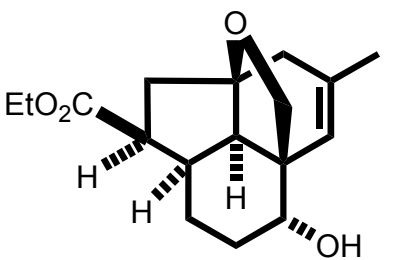

41

cis-Perhydronaphthalenes $\mathbf{3 9}$ and trans-Perhydronaphthalene $\mathbf{4 0}$ and $\mathbf{4 1 .}$ To a solution of $720 \mathrm{mg}(1.94 \mathrm{mmol})$ of bromide $15 \mathrm{and} 16 \mathrm{mg}(0.10 \mathrm{mmol})$ of azo-bis-isobutyronitrile in 200 $\mathrm{mL}$ of dry, degassed benzene, heated to $105^{\circ} \mathrm{C}$, was added a solution of $1.13 \mathrm{~g}(3.88 \mathrm{mmol})$ of tri- $n$-butyltin hydride in $4 \mathrm{~mL}$ of benzene over $1 \mathrm{~h}$ by syringe pump. The mixture was heated at reflux for $2 \mathrm{~h}$ (oil bath $105{ }^{\circ} \mathrm{C}$ ), the solvent was removed in vacuo, and the residue was purified by chromatography over $50 \mathrm{~g}$ of silica gel (hexanes-ethyl acetate, 5:1) to give $260 \mathrm{mg}$ (46\%) of trans-perhydronaphthalene $40,70 \mathrm{mg} \mathrm{(12 \% )}$ of trans-perhydronaphthalene 41 as colorless oils, and $130 \mathrm{mg}$ (23\%) of cis-perhydronaphthalene 39 as colorless crystals. cis-Perhydronaphthalene 39: $\mathrm{mp} 131-132{ }^{\circ} \mathrm{C}$; IR $\left(\mathrm{CHCl}_{3}\right) 3417,1713,1649 \mathrm{~cm}^{-1} ;{ }^{1} \mathrm{H}$ NMR $\left(\mathrm{CDCl}_{3}, 500 \mathrm{MHz}\right) \delta 1.30\left(\mathrm{t}, \mathrm{J}=7.5 \mathrm{~Hz}, 3 \mathrm{H}, \mathrm{CH}_{2} \mathrm{CH}_{3}\right), 1.48\left(\mathrm{~s}, 3 \mathrm{H}, \mathrm{CH}_{3}\right), 1.67\left(\mathrm{~s}, 3 \mathrm{H}, \mathrm{CH}_{3}\right), 1.74$ (s, $1 \mathrm{H}, \mathrm{OH}), 1.85$ and $4.05\left(\mathrm{~m}, 2 \mathrm{H}, \mathrm{C}(8) \mathrm{H}_{2}\right), 2.13$ and $2.45\left(\mathrm{ABq}, \mathrm{J}=18.5 \mathrm{~Hz}, 2 \mathrm{H}, \mathrm{CH}_{2}\right), 1.61$ and $1.92\left(\mathrm{~m}, 2 \mathrm{H}, \mathrm{C}(9) \mathrm{H}_{2}\right), 2.16(\mathrm{~s}, 1 \mathrm{H}, \mathrm{CH}), 3.77$ and $4.03\left(\mathrm{ABq}, 2 \mathrm{H}, \mathrm{C}(6) \mathrm{H}_{2}\right), 3.92(\mathrm{dd}, J=$ 11.5, $4.5 \mathrm{~Hz}, 1 \mathrm{H}, \underline{\mathrm{H}} \mathrm{OH}), 4.17\left(\mathrm{~m}, 2 \mathrm{H}, \mathrm{CH}_{2} \mathrm{CH}_{3}\right), 5.63$ (s, $\left.1 \mathrm{H},=\mathrm{CHCO}_{2} \mathrm{Et}\right), 5.64(\mathrm{~s}, 1 \mathrm{H}$, $\left.\mathrm{CH}_{3} \mathrm{C}=\mathrm{C} \underline{\mathrm{H}}\right) ;{ }^{13} \mathrm{C} \mathrm{NMR}\left(\mathrm{CDCl}_{3}, 125 \mathrm{MHz}\right) \delta 14.3(\mathrm{q}), 22.4(\mathrm{q}), 25.1$ (q), $27.6(\mathrm{t}), 32.2(\mathrm{t}), 43.9(\mathrm{t})$, $51.9(\mathrm{~s}), 55.4(\mathrm{~d}), 59.9(\mathrm{t}), 73.9(\mathrm{~d}), 80.0(\mathrm{t}), 80.4(\mathrm{~s}), 112.6(\mathrm{~d}), 121.3(\mathrm{~d}), 135.4(\mathrm{~s}), 155.3(\mathrm{~s})$ 166.5 (s); exact mass calcd. for $\mathrm{C}_{17} \mathrm{H}_{24} \mathrm{O}_{4}(\mathrm{M}+\mathrm{Na})^{+} \mathrm{m} / \mathrm{z}$ 315.1572, found $\mathrm{m} / \mathrm{z} 315.1570$. trans-Perhydronaphthalene 40: IR (neat) 3457, $1712,1637 \mathrm{~cm}^{-1} ;{ }^{1} \mathrm{H} \mathrm{NMR}\left(\mathrm{CDCl}_{3}, 400 \mathrm{MHz}\right) \delta$ $1.30\left(\mathrm{t}, J=7.0 \mathrm{~Hz}, 3 \mathrm{H}, \mathrm{CH}_{2} \mathrm{CH}_{3}\right), 1.40\left(\mathrm{~s}, 3 \mathrm{H}, \mathrm{CH}_{3}\right), 1.68\left(\mathrm{br} \mathrm{s}, 4 \mathrm{H}, \mathrm{CH}_{3}\right.$ and $\left.\mathrm{OH}\right), 1.88$ and 2.25 
(m, 2H, C(8) $\left.\mathrm{H}_{2}\right), 2.37$ and $2.59\left(\mathrm{ABq}, J=18.0 \mathrm{~Hz}, 2 \mathrm{H}, \mathrm{CH}_{2}\right), 2.58$ and $3.50\left(\mathrm{~m}, 2 \mathrm{H}, \mathrm{C}(9) \mathrm{H}_{2}\right)$, $2.70(\mathrm{~s}, 1 \mathrm{H}, \mathrm{CH}), 3.91\left(\mathrm{~s}, 2 \mathrm{H}, \mathrm{C}(6) \mathrm{H}_{2}\right), 4.00(\mathrm{dd}, J=6.0,1.5 \mathrm{~Hz}, 1 \mathrm{H}, \underline{\mathrm{CHOH}}), 4.17(\mathrm{~m}, 2 \mathrm{H}$, $\left.\mathrm{CH}_{2} \mathrm{CH}_{3}\right), 5.87\left(\mathrm{~s}, 1 \mathrm{H},=\mathrm{C} \underline{\mathrm{H} C O}{ }_{2} \mathrm{Et}\right), 5.91\left(\mathrm{~s}, 1 \mathrm{H}, \mathrm{CH}_{3} \mathrm{C}=\mathrm{C} \underline{\mathrm{H}}\right) ;{ }^{13} \mathrm{C} \mathrm{NMR}\left(\mathrm{CDCl}_{3}, 125 \mathrm{MHz}\right) \delta 14.3$ (q), $21.9(q), 22.6(t), 23.4(q), 31.9(t), 50.1(t), 53.4(s), 54.9(d), 59.7(t), 67.0(d), 79.0(t)$, 84.1 (s), 117.5 (d), 131.6 (d), 134.5 (s), 158.8 (s), 166.4 (s); exact mass calcd. for $\mathrm{C}_{17} \mathrm{H}_{24} \mathrm{O}_{4}$ $(\mathrm{M}+\mathrm{Na})^{+} \mathrm{m} / \mathrm{z}$ 315.1572, found $\mathrm{m} / \mathrm{z}$ 315.1570. $\quad$ trans-Perhydronaphthalene 41: IR (neat) 3424, $1728 \mathrm{~cm}^{-1} ;{ }^{1} \mathrm{H} \mathrm{NMR}\left(\mathrm{CDCl}_{3}, 500 \mathrm{MHz}\right) \delta 1.25$ (t, $\left.J=7.0 \mathrm{~Hz}, 3 \mathrm{H}, \mathrm{CH}_{2} \mathrm{CH}_{3}\right), 1.70\left(\mathrm{~s}, 3 \mathrm{H}, \mathrm{CH}_{3}\right)$, 1.38 and $2.47\left(\mathrm{~m}, 2 \mathrm{H}, \mathrm{CH}_{2} \mathrm{CHOH}\right), 1.75$ and $1.78\left(\mathrm{~m}, 2 \mathrm{H}, \mathrm{C}(6) \mathrm{H}_{2}\right), 1.75(\mathrm{br} \mathrm{s}, 1 \mathrm{H}, \mathrm{OH}), 1.85$ and $2.66\left(\mathrm{dd}, 2 \mathrm{H}, J=14.0,10.0 \mathrm{~Hz}, \underline{\mathrm{H}}_{2} \mathrm{COR}\right.$ ), 2.30 and $2.45\left(\mathrm{ABq}, J=17.0 \mathrm{~Hz}, 2 \mathrm{H}, \mathrm{CH}_{2}\right.$ ), $2.24\left(\mathrm{~d}, J=11.5 \mathrm{~Hz}, 1 \mathrm{H}, \mathrm{CO}_{2} \mathrm{EtCHCHC} \underline{\mathrm{H}}\right), 2.66\left(\mathrm{~m}, 1 \mathrm{H}, \mathrm{CO}_{2} \mathrm{EtCHCHCH}\right), 3.26(\mathrm{t}, J=10.0 \mathrm{~Hz}$, $1 \mathrm{H}, \mathrm{C} \underline{\mathrm{H} O H}), 3.66$ and $3.81\left(\mathrm{ABq}, J=7.0 \mathrm{~Hz}, 2 \mathrm{H}, \mathrm{CH}_{2}\right), 3.96(\mathrm{dd}, J=7.5,6.0 \mathrm{~Hz}, 1 \mathrm{H}$, $\left.\mathrm{CH}_{\mathrm{H} C O} \mathrm{Et}\right), 4.13$ (q, J=7.0 Hz, 2H, CH $\left.\mathrm{CH}_{3}\right), 6.03(\mathrm{~s}, 1 \mathrm{H},=\mathrm{C} \underline{\mathrm{H}}) ;{ }^{13} \mathrm{C} \mathrm{NMR}\left(\mathrm{CDCl}_{3}, 125 \mathrm{MHz}\right) \delta$ $14.4(q), 20.4(t), 22.7(q), 33.2(t), 37.3(d), 38.0(t), 44.1(t), 47.7(d), 50.8(d), 51.0(s), 59.9(t)$ 65.2 (d), 81.5 (t), 93.3 (s), 130.8 (d), 134.8 (s), 173.7 (s); exact mass calcd. for $\mathrm{C}_{17} \mathrm{H}_{24} \mathrm{O}_{4}$ $(\mathrm{M}+\mathrm{Na})^{+} \mathrm{m} / \mathrm{z} 315.1572$, found $\mathrm{m} / \mathrm{z} 315.1553$. 


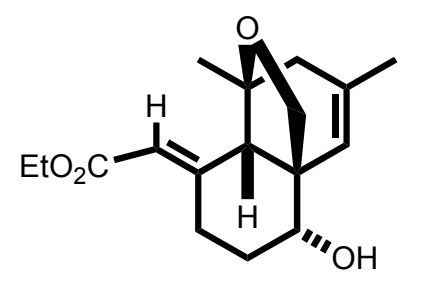

39

(500 MHz, $\mathrm{CDCl}_{3}$ )

DY-2-47E

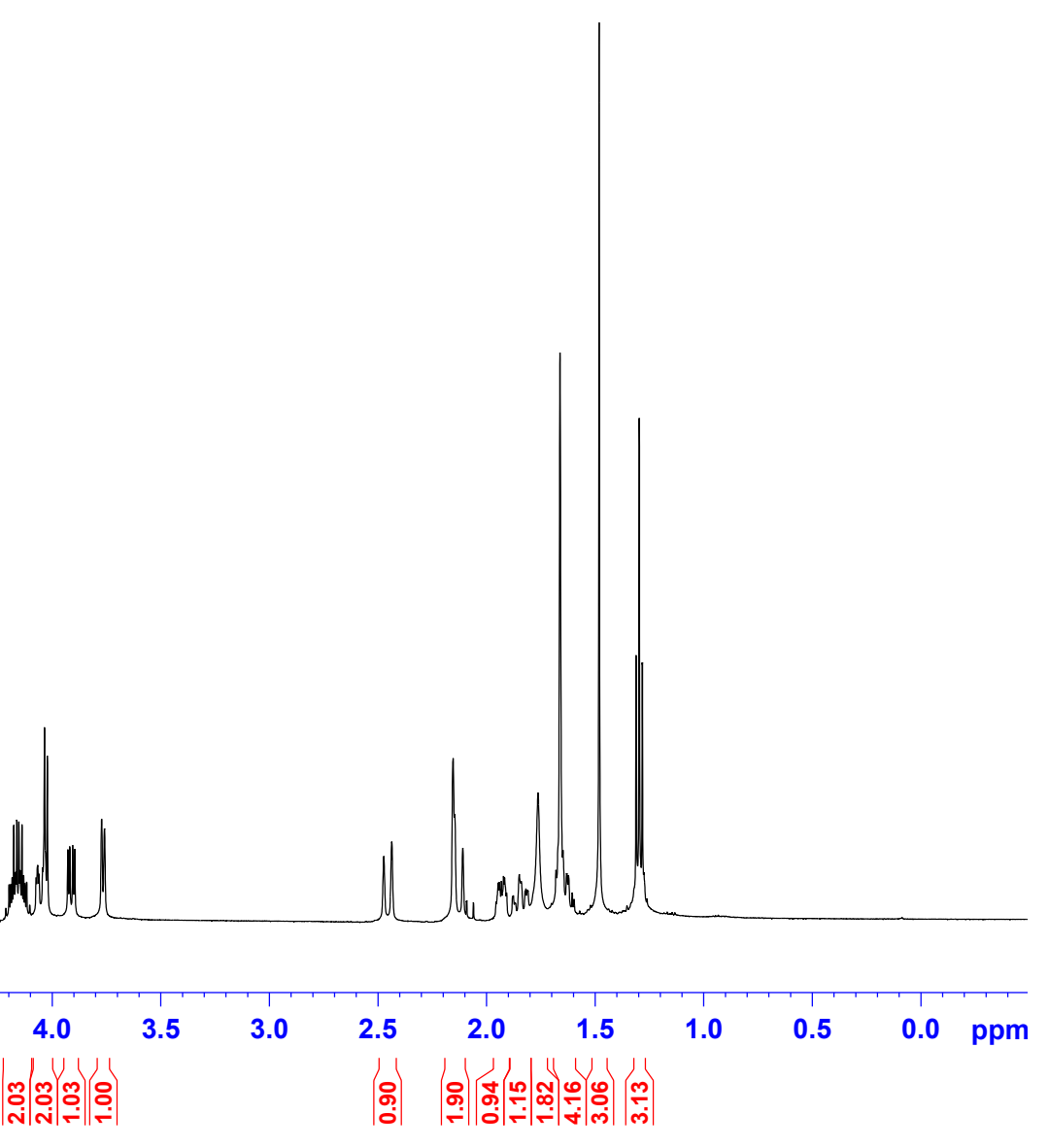

147 


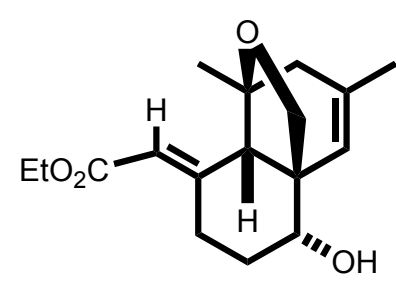

39

(500 MHz, $\mathrm{CDCl}_{3}$ )

DY-2-47E

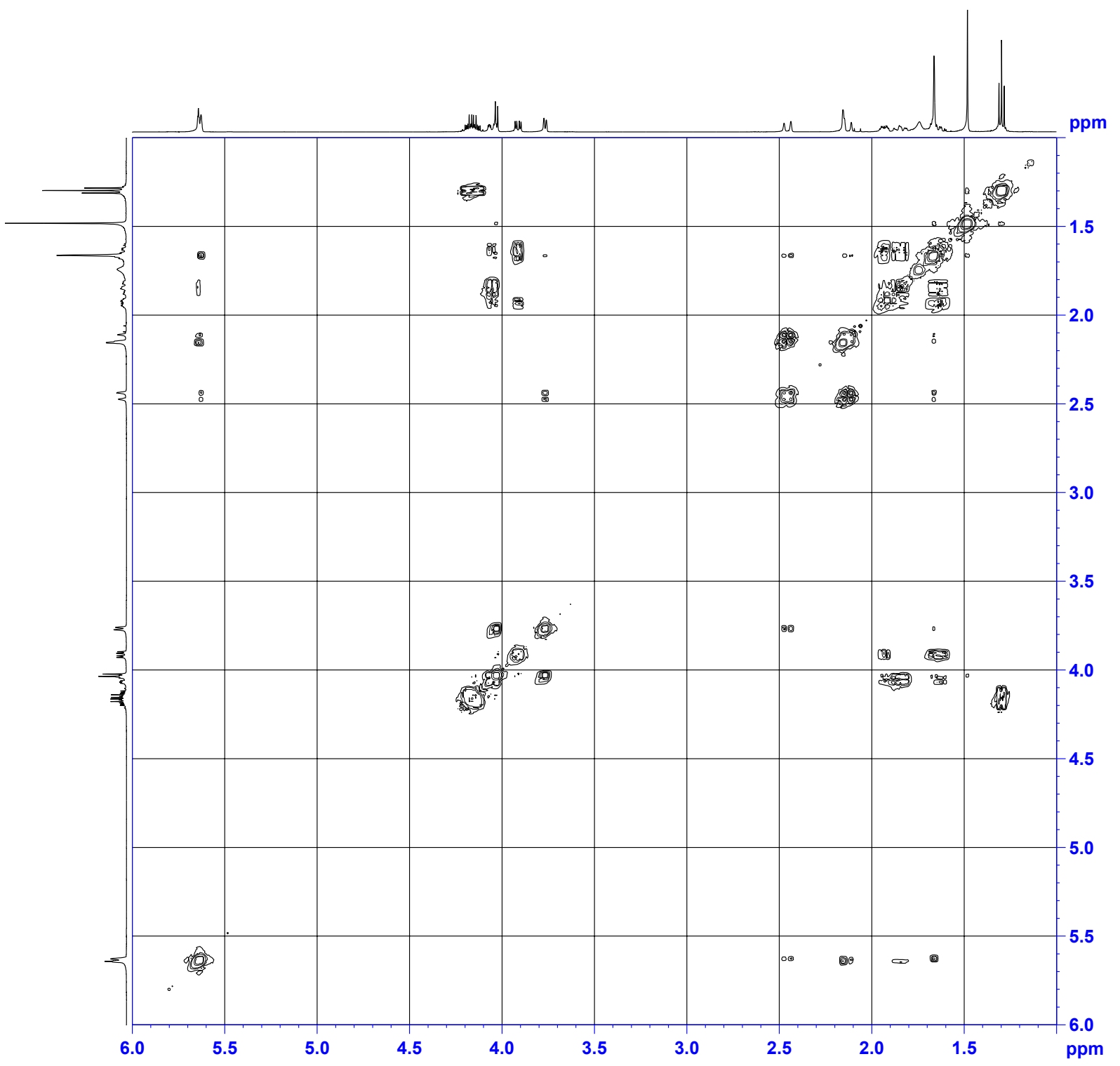

148 


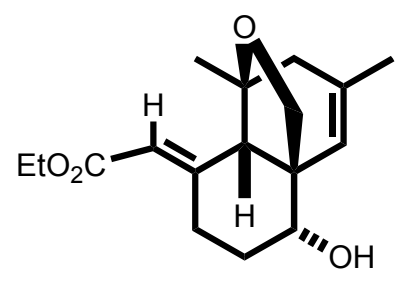

39

(125 MHz, $\mathrm{CDCl}_{3}$ )

DY-2-47E

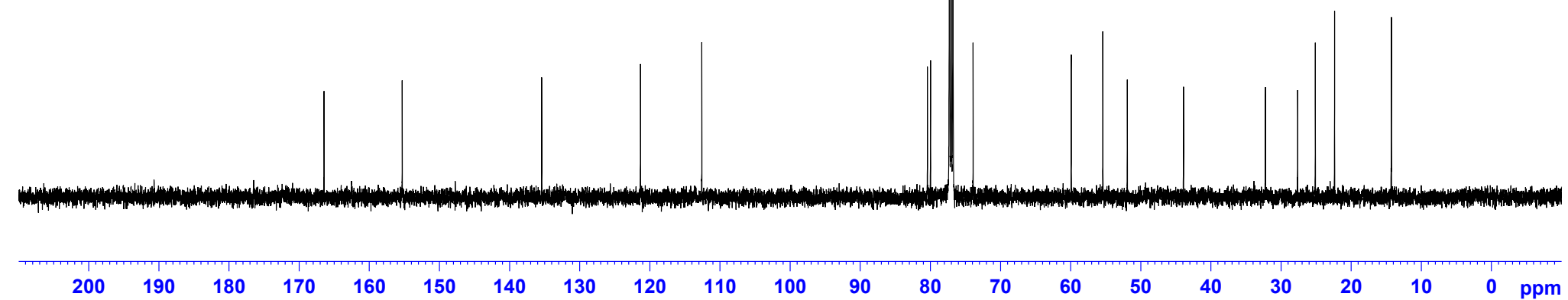




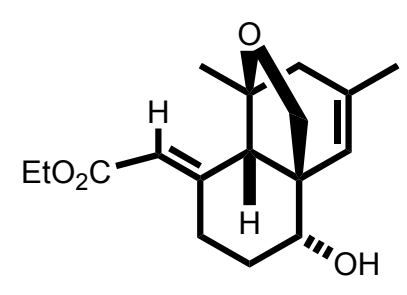

39

(125 MHz, $\left.\mathrm{CDCl}_{3}\right)$

DY-2-47E

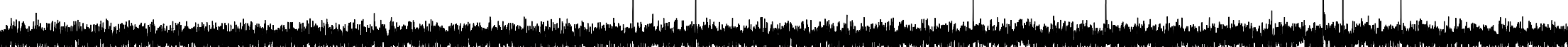

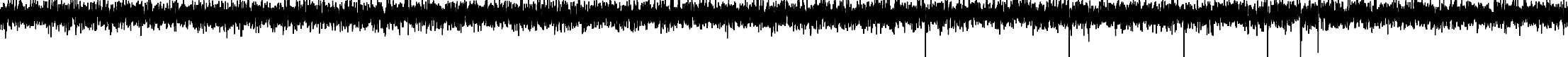

$\begin{array}{lllllllllll}200 & 190 & 180 & 170 & 160 & 150 & 140 & 130 & 120 & 110 & 100\end{array}$

$90 \quad 80$

70

60 


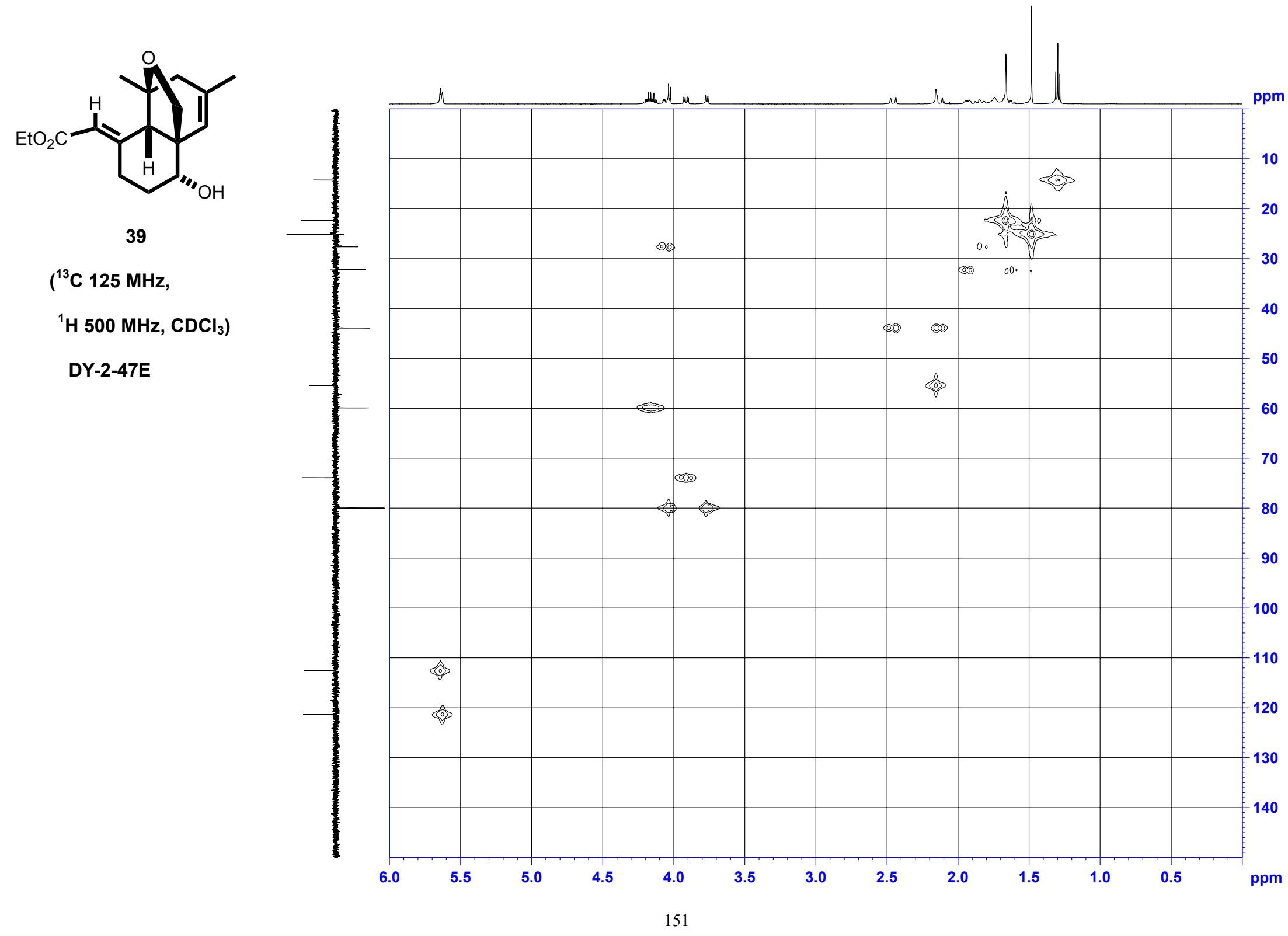




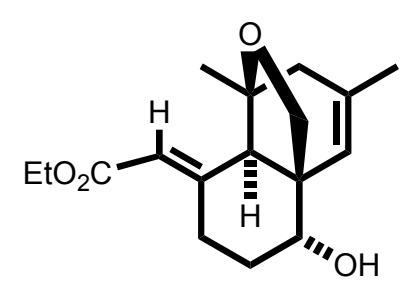

40

(400 MHz, $\mathrm{CDCl}_{3}$ )

DY-2-47A
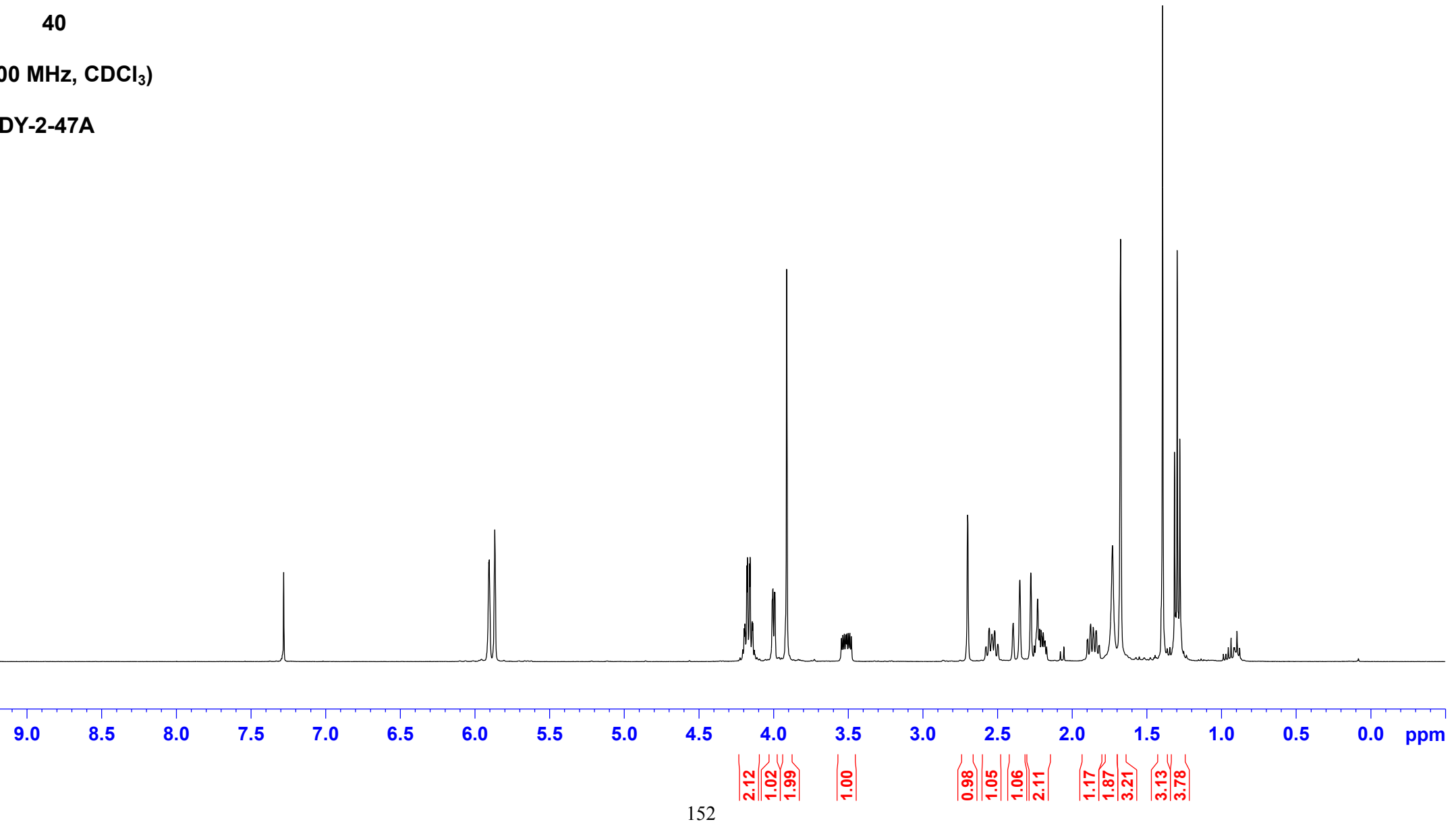


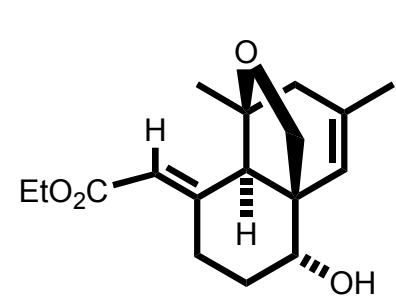

40

(500 MHz, $\mathrm{CDCl}_{3}$ )

DY-2-47A

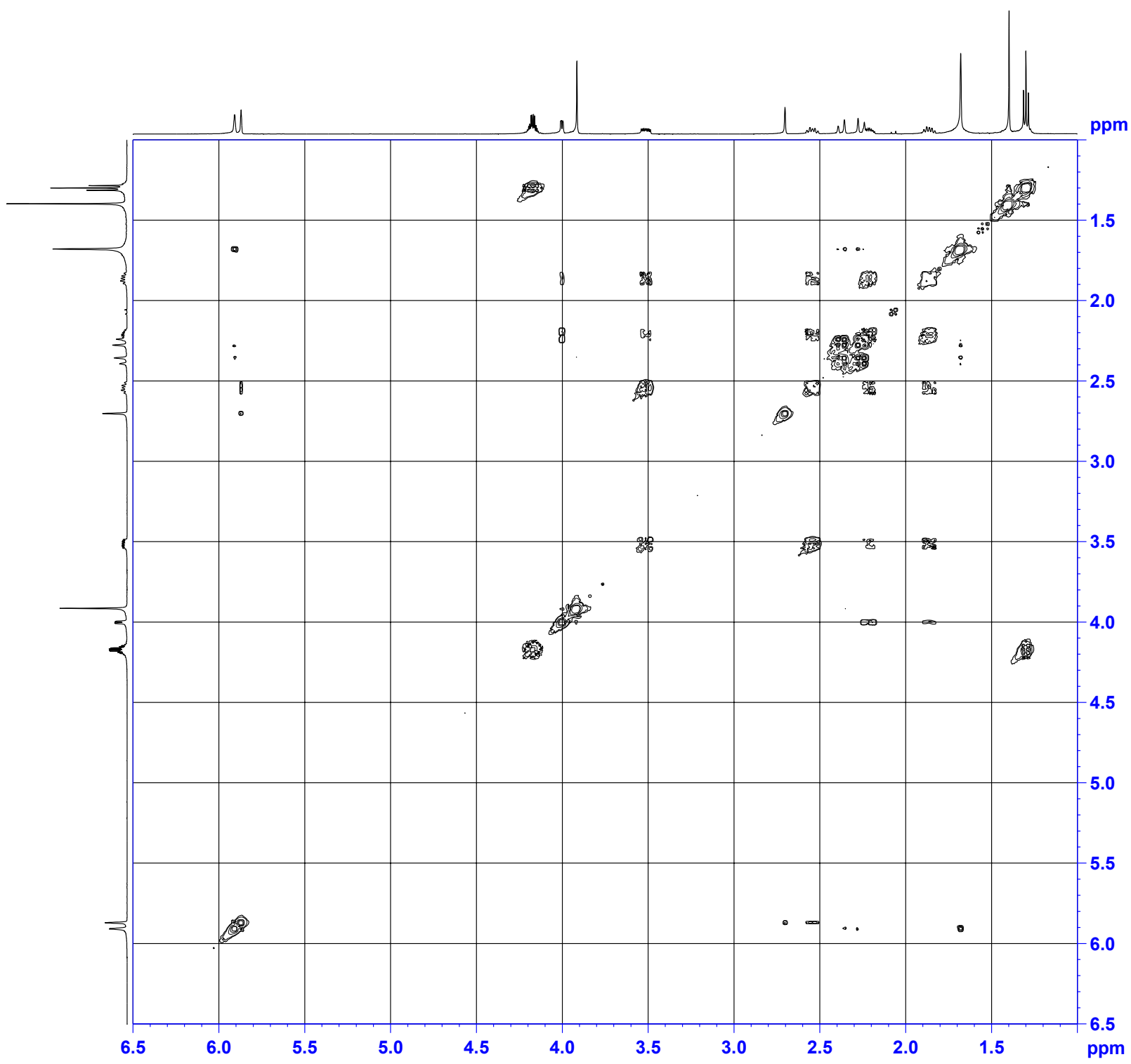

153 

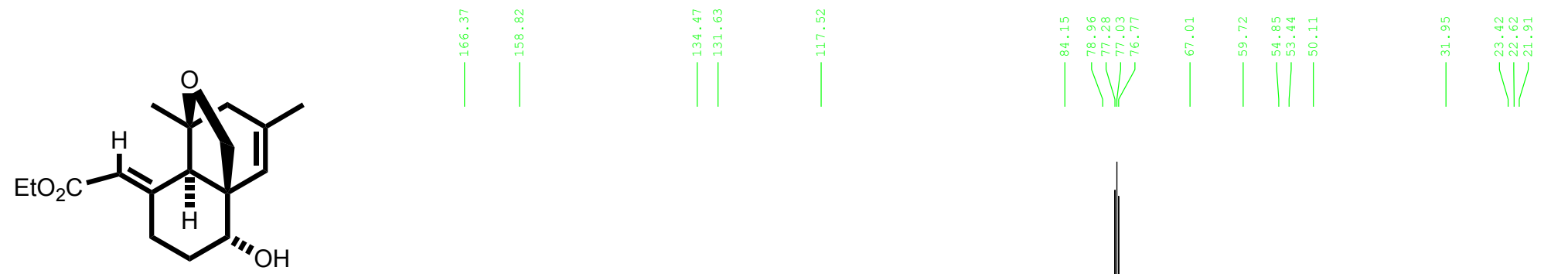

40

(125 MHz, $\mathrm{CDCl}_{3}$ )

DY-2-47A

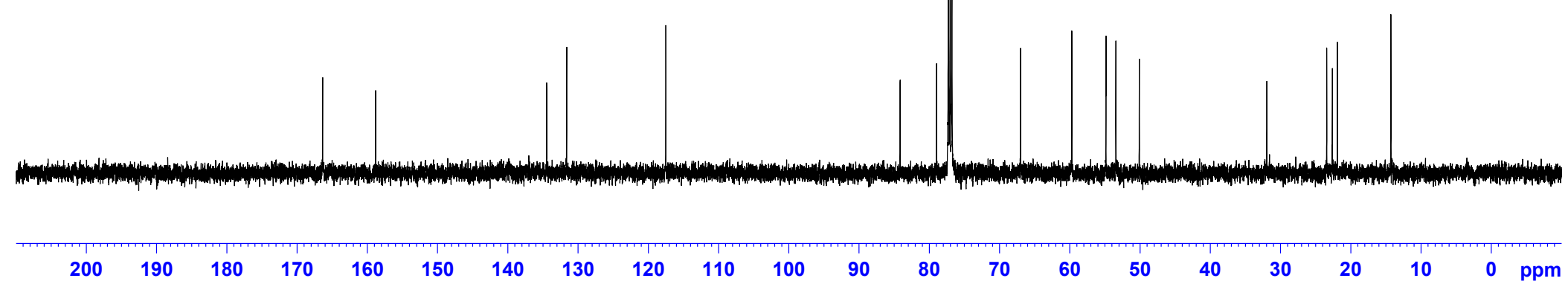




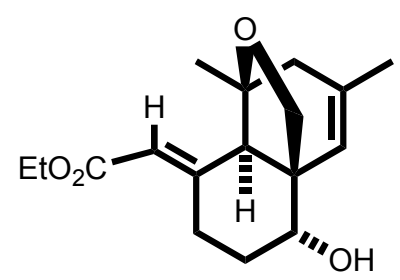

40

(125 MHz, $\mathrm{CDCl}_{3}$ )

DY-2-47A

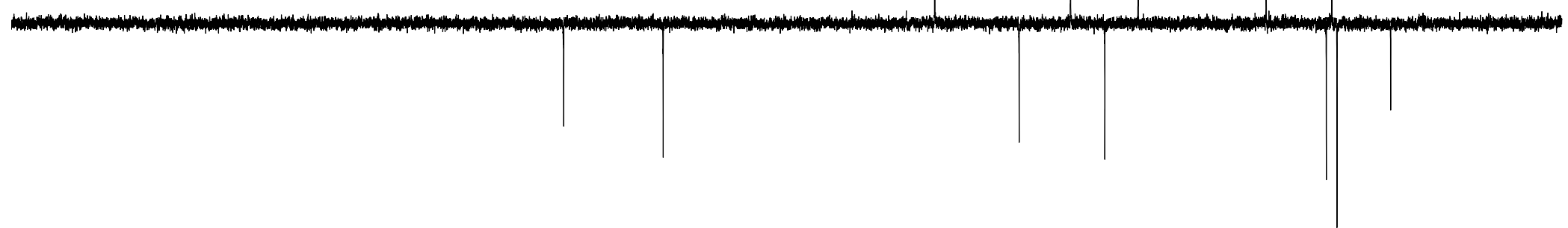
200
$190 \quad 180$
$170 \quad 160$ 


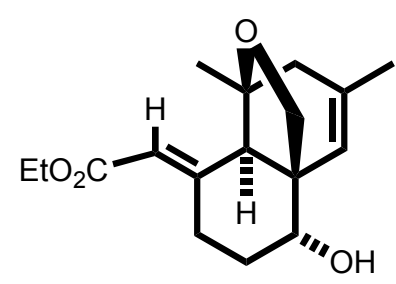

40

$\left({ }^{13} \mathrm{C} 125 \mathrm{MHz}\right.$,

${ }^{1} \mathrm{H} 500 \mathrm{MHz}, \mathrm{CDCl}_{3}$ )

DY-2-47A

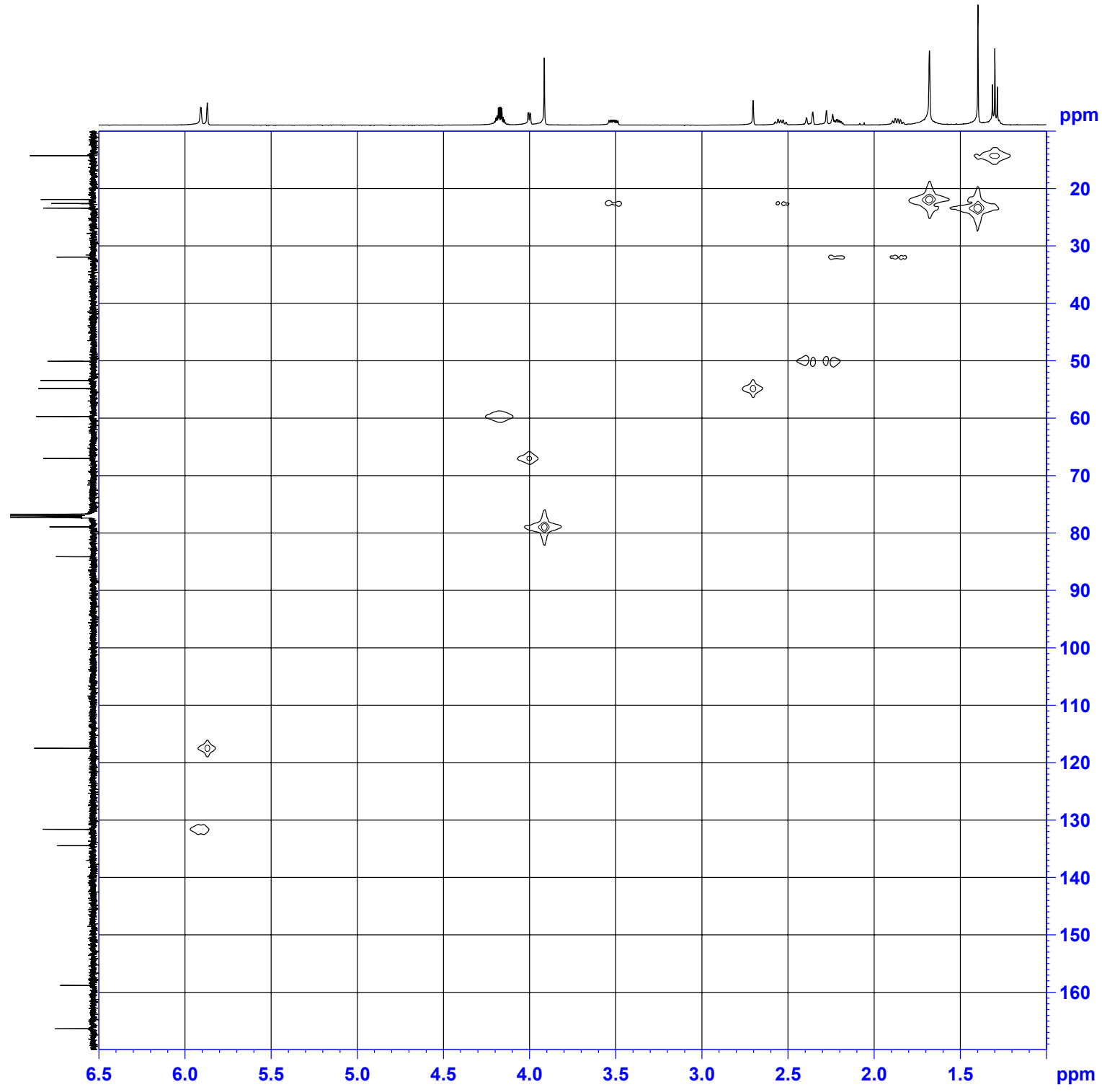

156 


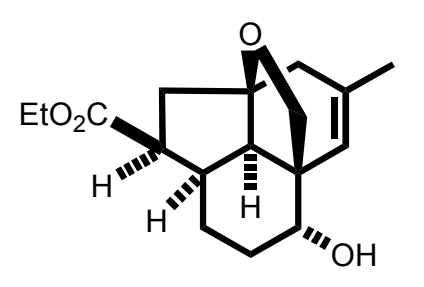

41

(500 MHz, $\mathrm{CDCl}_{3}$ )

DY-2-47D

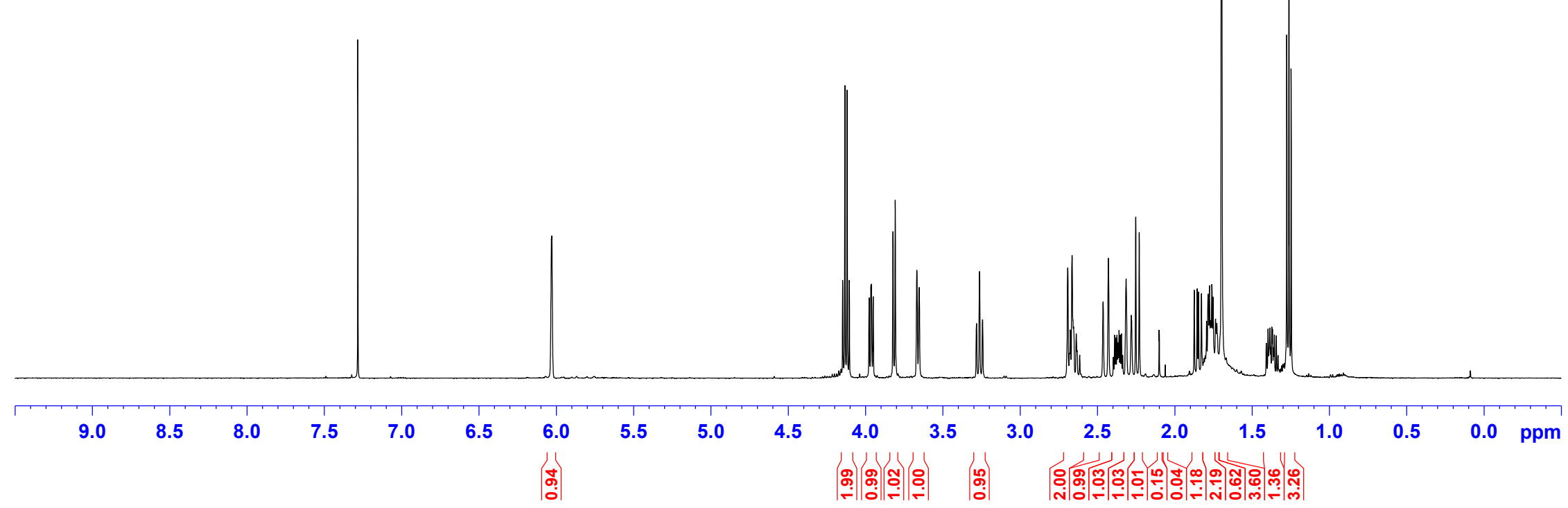

157 


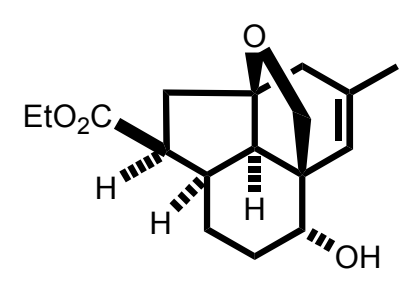

41

(500 MHz, $\mathrm{CDCl}_{3}$ )

DY-2-47D

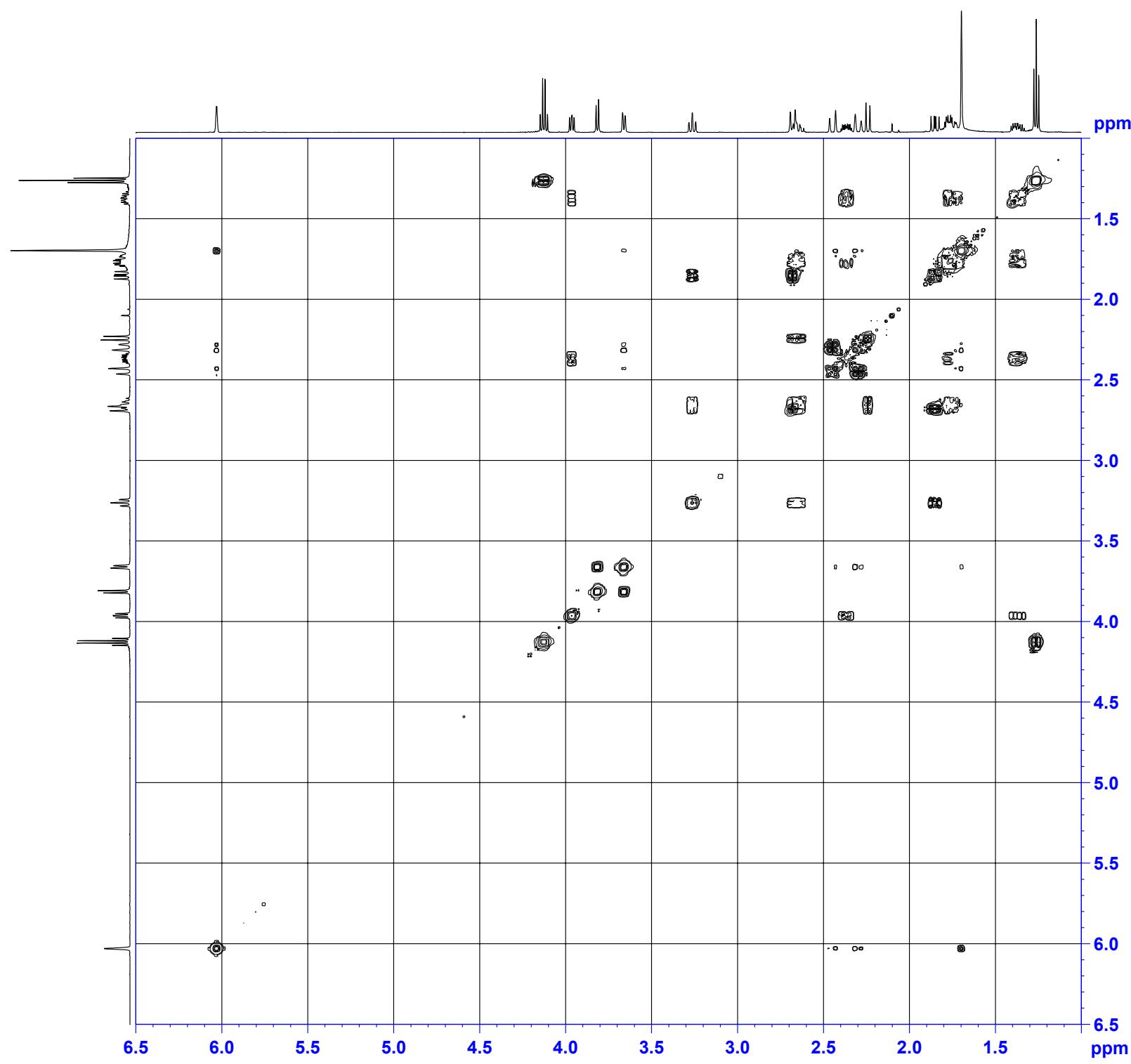

158 


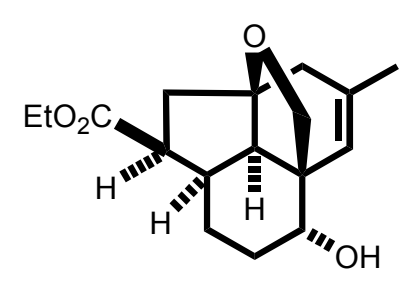

41

(125 MHz, $\mathrm{CDCl}_{3}$ )

DY-2-47D

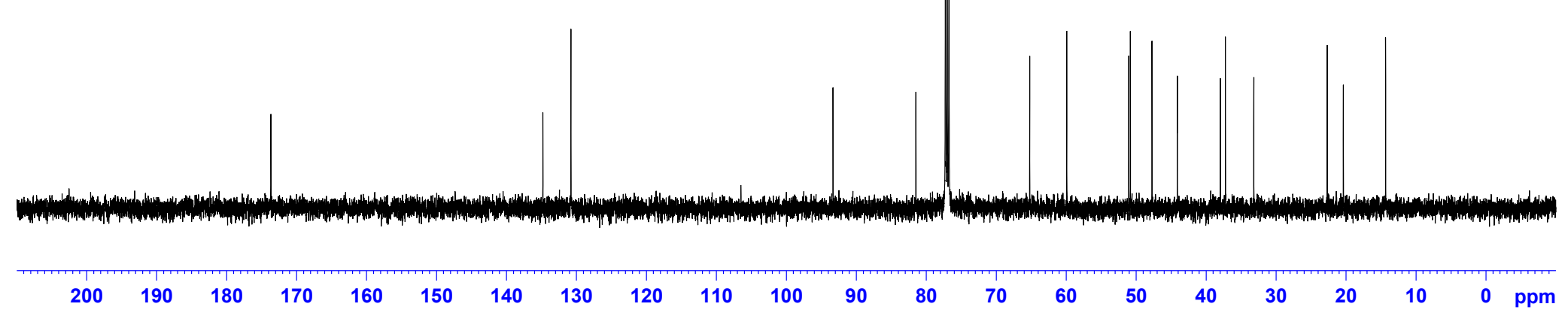




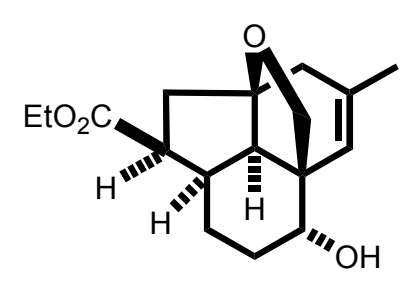

41

(125 MHz, $\mathrm{CDCl}_{3}$ )

DY-2-47D

200

$190 \quad 180$

$170 \quad 160$

150

130

$110 \quad 100$

90

80

70

60

50

40

30

$20 \quad 10$ 


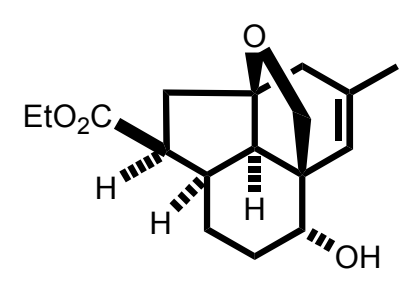

41

('H 500 MHz,

${ }^{13} \mathrm{C} 125 \mathrm{MHz}, \mathrm{CDCl}_{3}$ )

DY-2-47D

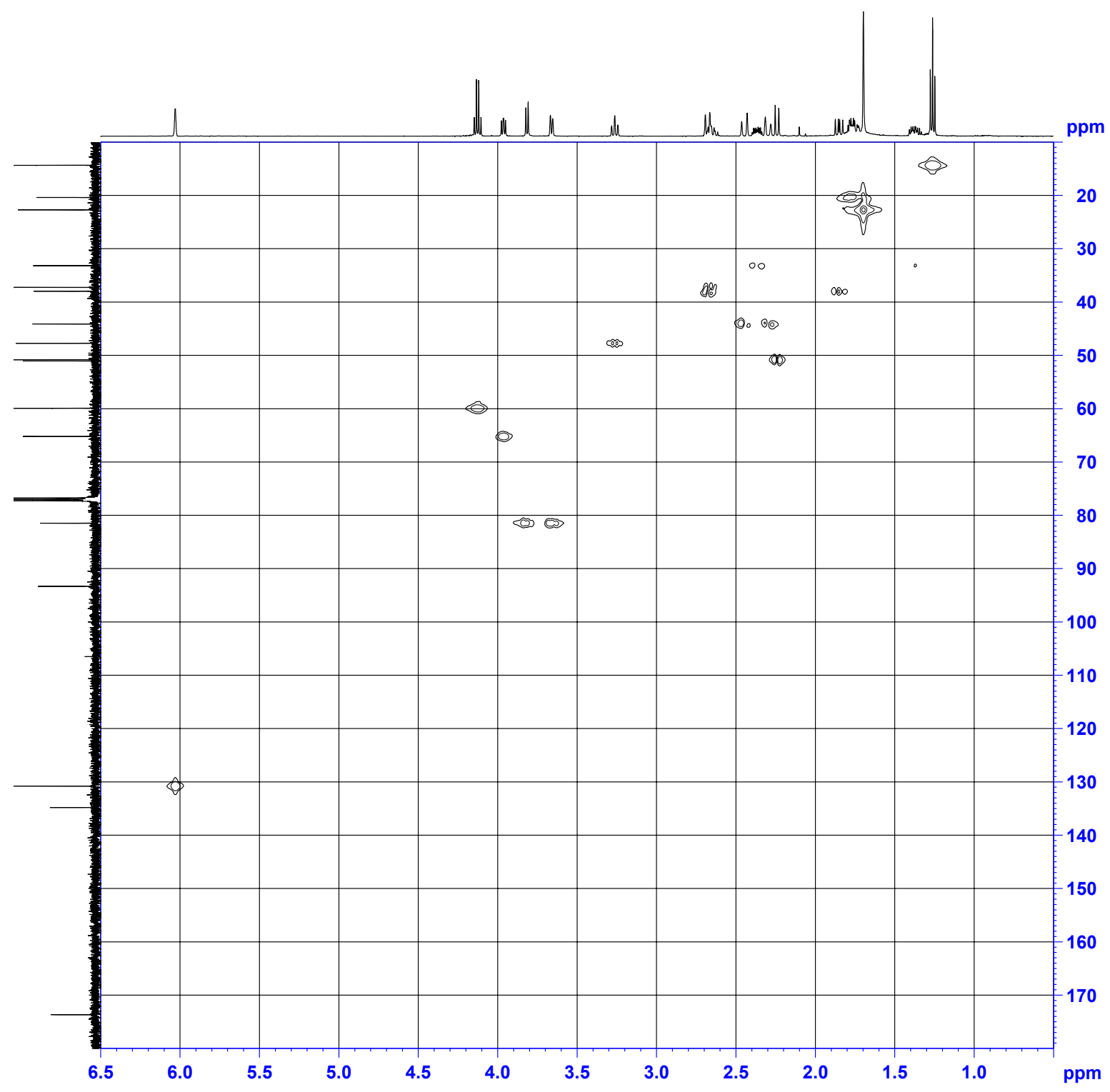

161 


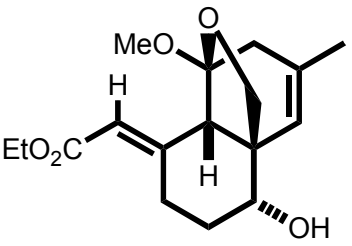

42

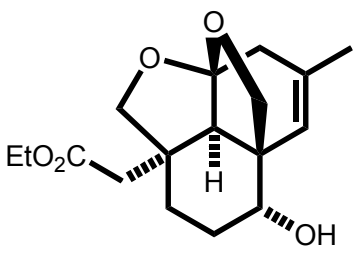

43

cis-Perhydronaphthalene 42 and trans-Perhydronaphthalene 43. To a solution of 100 $\mathrm{mg}(0.26 \mathrm{mmol})$ of bromide 25 and $2.1 \mathrm{mg}(0.013 \mathrm{mmol})$ of azo-bis-isobutyronitrile in $20 \mathrm{~mL}$ of dry, degassed benzene heated to $105^{\circ} \mathrm{C}$ was added a solution of $0.15 \mathrm{~g}(0.52 \mathrm{mmol})$ of tri-n-butyltin hydride in $1 \mathrm{~mL}$ of benzene over $10 \mathrm{~min}$ by syringe. The mixture was warmed under reflux (oil bath $105^{\circ} \mathrm{C}$ ) for $2 \mathrm{~h}$, the solvent was removed in vacuo, and the residue was purified by chromatography over $20 \mathrm{~g}$ of silica gel (hexanes-ethyl acetate, 5:1) to give $15 \mathrm{mg}$ (19\%) of cis-perhydronaphthalene $\mathbf{4 2}$ and $32 \mathrm{mg}$ (41\%) of trans-perhydronaphthalene $\mathbf{4 3}$ as colorless oils. cis-Perhydronaphthalene 42: IR (neat) $3454,1722,1644 \mathrm{~cm}^{-1} ;{ }^{1} \mathrm{H}$ NMR $\left(\mathrm{C}_{6} \mathrm{D}_{6}\right.$, $500 \mathrm{MHz}) \delta 0.82(\mathrm{br} \mathrm{d}, 1 \mathrm{H}, \mathrm{CHO} \underline{\mathrm{H}}), 1.06\left(\mathrm{t}, J=7.0 \mathrm{~Hz}, 3 \mathrm{H}, \mathrm{OCH}_{2} \mathrm{C}_{3}\right), 1.37\left(\mathrm{~s}, 3 \mathrm{H}, \mathrm{CH}_{3}\right), 1.06$ and $4.46\left(\mathrm{~m}, 2 \mathrm{H}, \mathrm{C}(8) \mathrm{H}_{2}\right), 1.53$ and $1.70\left(\mathrm{~m}, 2 \mathrm{H}, \mathrm{C}(9) \mathrm{H}_{2}\right), 2.45(\mathrm{~s}, 1 \mathrm{H}, \mathrm{CH}), 2.57$ and $2.84(\mathrm{ABq}$, $\left.J=18.0 \mathrm{~Hz}, 2 \mathrm{H}, \mathrm{CH}_{2}\right), 3.31(\mathrm{~m}, 1 \mathrm{H}, \mathrm{C} \underline{\mathrm{HOH}}), 3.74$ and $4.16\left(\mathrm{ABq}, 2 \mathrm{H}, \mathrm{C}(6) \mathrm{H}_{2}\right), 3.37(\mathrm{~s}, 3 \mathrm{H}$, $\left.\mathrm{OCH}_{3}\right), 4.05\left(\mathrm{~m}, 2 \mathrm{H}, \mathrm{CH}_{2} \mathrm{CH}_{3}\right), 5.76\left(\mathrm{~s}, 1 \mathrm{H}, \mathrm{CH}_{3} \mathrm{C}=\mathrm{C} \underline{\mathrm{H}}\right), 6.50\left(\mathrm{~s}, 1 \mathrm{H},=\mathrm{CH}_{\underline{H}} \mathrm{CO}_{2} \mathrm{Et}\right) ;{ }^{13} \mathrm{C} N M R$ $\left(\mathrm{C}_{6} \mathrm{D}_{6}, 125 \mathrm{MHz}\right) \delta 14.0(\mathrm{q}), 22.0(\mathrm{q}), 27.1(\mathrm{t}), 31.5(\mathrm{t}), 42.5(\mathrm{t}), 48.6(\mathrm{~d}), 48.9(\mathrm{q}), 50.9(\mathrm{~s}), 59.5$ (t), $72.7(d), 79.1(t), 107.6(s), 113.6(d), 121.6(d), 135.4(s), 154.3(s) 166.1(s)$; exact mass calcd. for $\mathrm{C}_{17} \mathrm{H}_{24} \mathrm{O}_{5}(\mathrm{M}+\mathrm{Na})^{+} \mathrm{m} / \mathrm{z}$ 331.1521, found 331.1521. trans-Perhydronaphthalene 43: IR (neat) 3452, $1731 \mathrm{~cm}^{-1} ;{ }^{1} \mathrm{H}$ NMR $\left(\mathrm{C}_{6} \mathrm{D}_{6}, 500 \mathrm{MHz}\right) \delta 1.03\left(\mathrm{t}, \mathrm{J}=7.0 \mathrm{~Hz}, 3 \mathrm{H}, \mathrm{CH}_{2} \mathrm{CH}_{3}\right), 1.32(\mathrm{~d}$, $J=5.0 \mathrm{~Hz}, 1 \mathrm{H}, \mathrm{OH}), 1.48$ and $1.82\left(\mathrm{~m}, 2 \mathrm{H}, \mathrm{C}(6) \mathrm{H}_{2}\right), 1.51$ and $1.96\left(\mathrm{~m}, 2 \mathrm{H}, \mathrm{C}_{2} \mathrm{CHOH}\right), 1.62(\mathrm{~s}$, $\left.3 \mathrm{H}, \mathrm{CH}_{3}\right), 2.10(\mathrm{~s}, 1 \mathrm{H}, \mathrm{C}(9) \mathrm{H}), 2.39$ and $2.59\left(\mathrm{ABq}, 2 \mathrm{H}, J=15.0, \mathrm{C}_{2} \mathrm{COR}\right), 2.70$ and 2.83 
(ABq, $\left.J=16.0 \mathrm{~Hz}, 2 \mathrm{H}, \mathrm{CH}_{2}\right), 3.55(\mathrm{~m}, 1 \mathrm{H}, \mathrm{C} \underline{\mathrm{HOH}}), 3.68$ and $3.74\left(\mathrm{ABq}, J=7.5 \mathrm{~Hz}, 2 \mathrm{H}, \mathrm{CH}_{2}\right)$, $4.00\left(\mathrm{q}, J=7.0 \mathrm{~Hz}, 2 \mathrm{H}, \mathrm{CH}_{2} \mathrm{CH}_{3}\right), 4.30$ and $4.72\left(\mathrm{ABq}, J=9.0 \mathrm{~Hz}, 2 \mathrm{H}, \mathrm{CH}_{2}\right), 5.88(\mathrm{~s}, 1 \mathrm{H},=\mathrm{CH})$; ${ }^{13} \mathrm{CNMR}\left(\mathrm{C}_{6} \mathrm{D}_{6}, 125 \mathrm{MHz}\right) \delta 14.0(\mathrm{q}), 22.5(\mathrm{q}), 27.3(\mathrm{t}), 30.1(\mathrm{t}), 38.5(\mathrm{~s}), 43.5(\mathrm{t}), 44.3(\mathrm{t}), 51.2$ $(\mathrm{s}), 55.5(\mathrm{~d}), 60.1(\mathrm{t}), 64.0(\mathrm{~d}), 79.2(\mathrm{t}), 82.2(\mathrm{t}), 117.2(\mathrm{~s}), 131.5(\mathrm{~d}), 134.5(\mathrm{~s}), 171.5(\mathrm{~s})$; exact mass calcd. for $\mathrm{C}_{17} \mathrm{H}_{24} \mathrm{O}_{5}(\mathrm{M}+\mathrm{Na})^{+} \mathrm{m} / \mathrm{z} 331.1521$, found 331.1520 . 


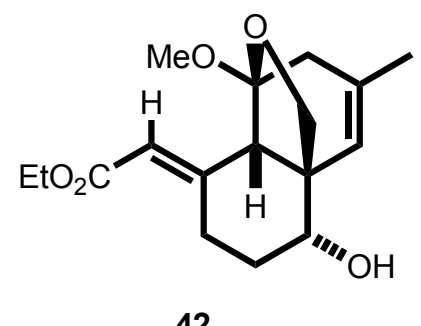

42

(500 MHz, $\mathrm{C}_{6} \mathrm{D}_{6}$ )

DY-2-86C

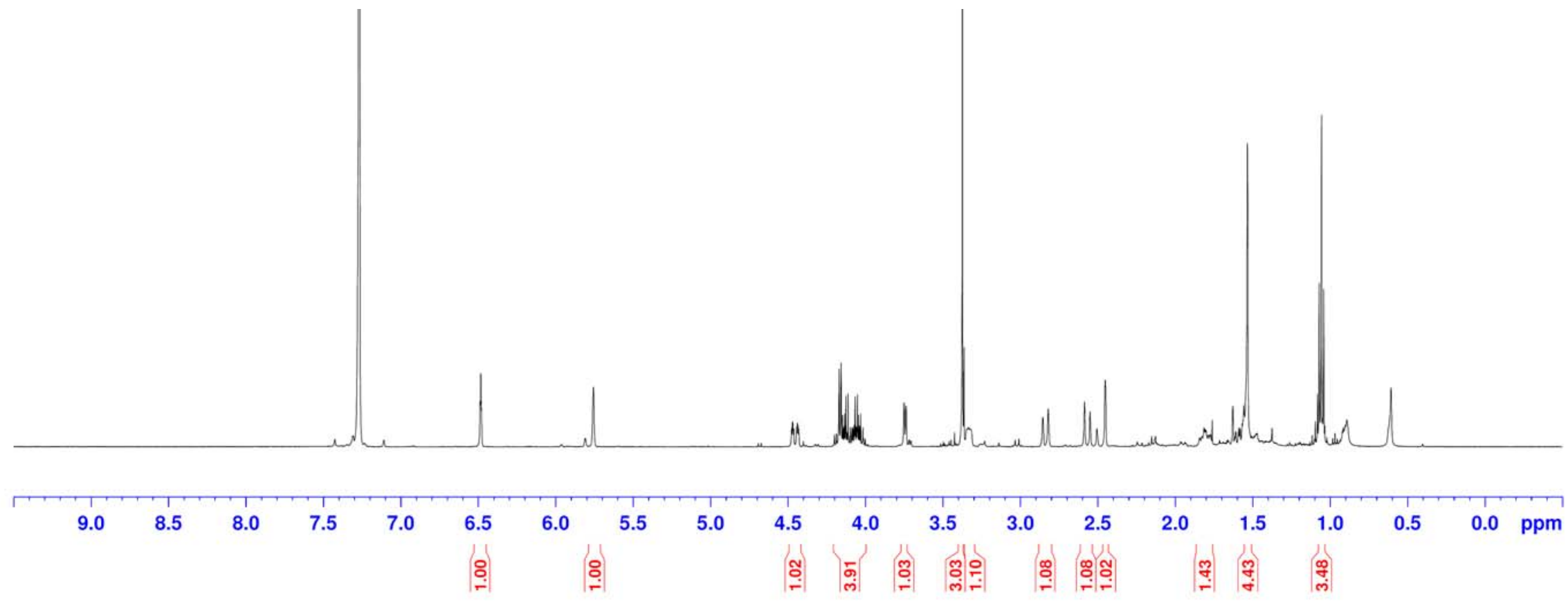




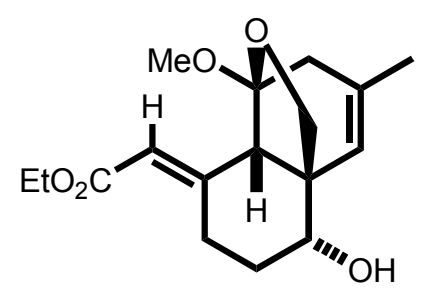

42

(500 MHz, $\mathrm{C}_{6} \mathrm{D}_{6}$ )

DY-2-86C

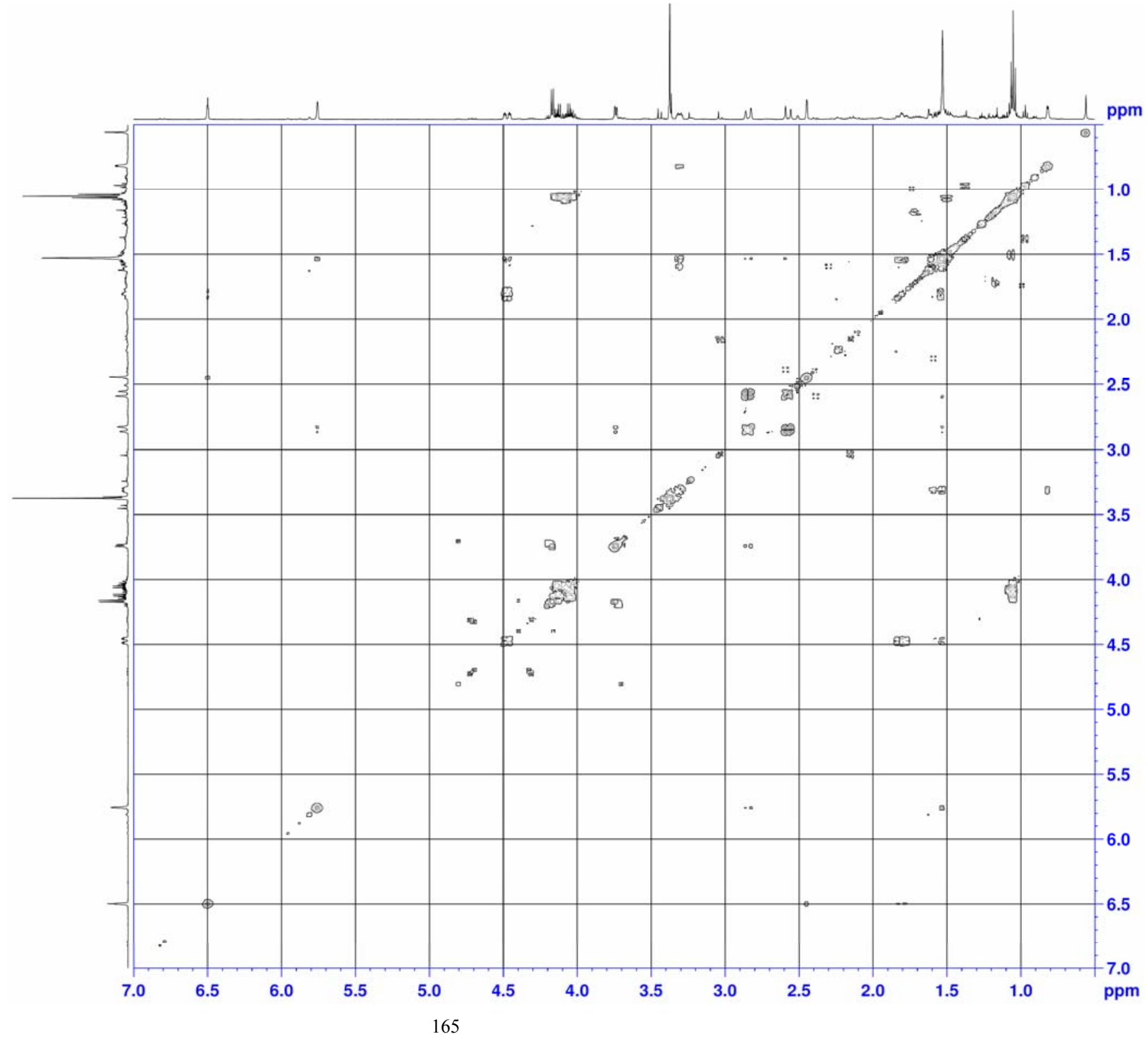




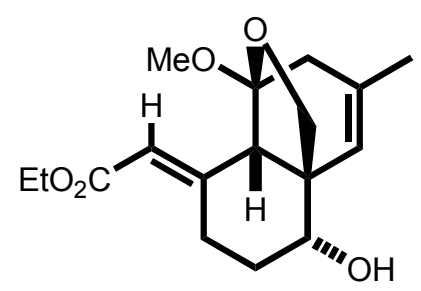

42

(125 MHz, $\mathrm{C}_{6} \mathrm{D}_{6}$ )

DY-2-86C

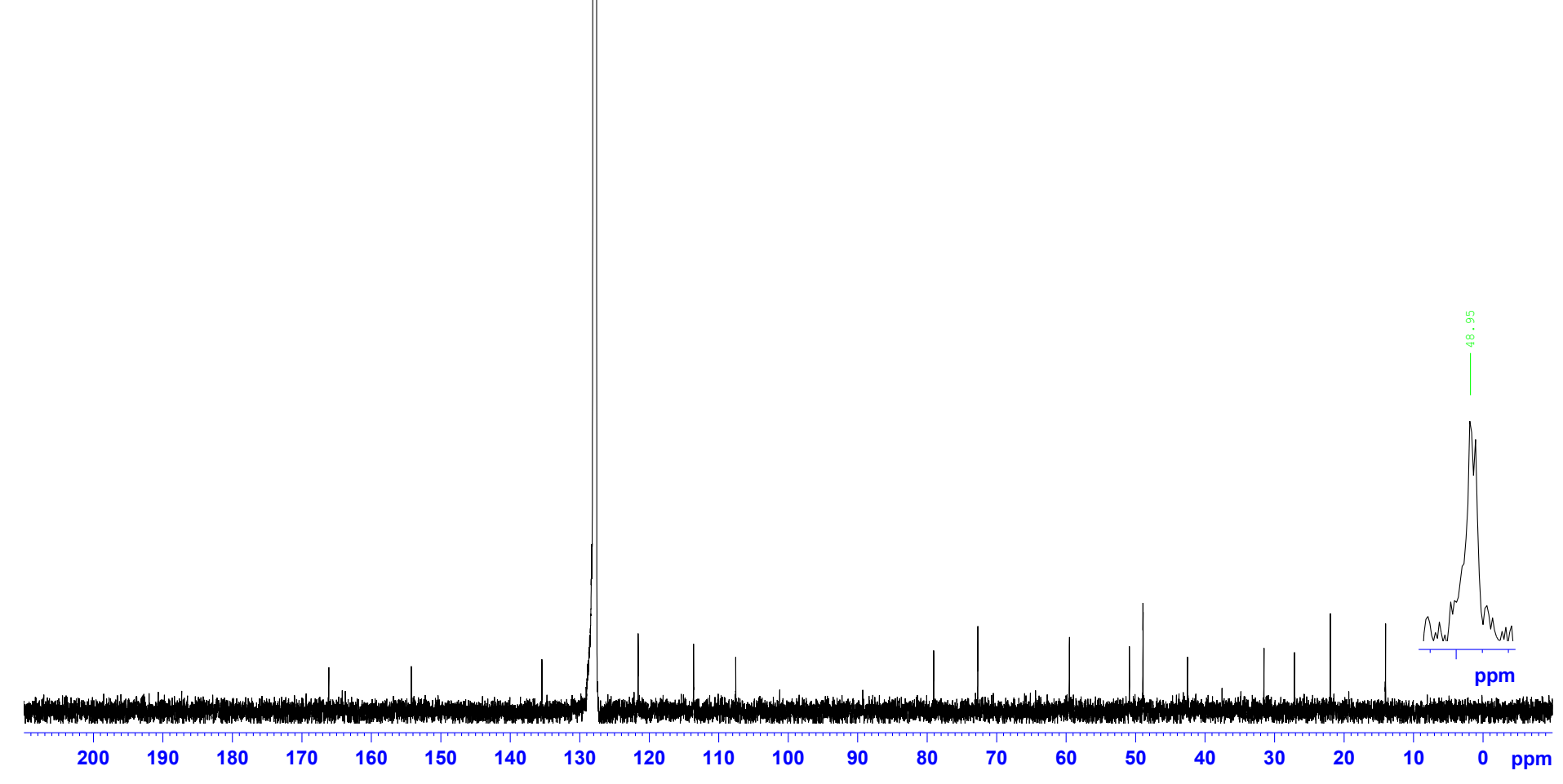




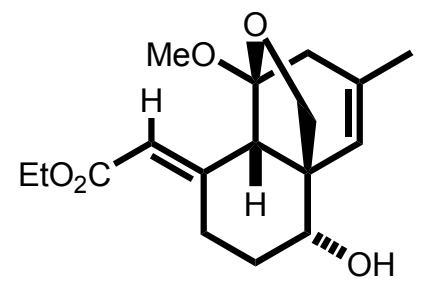

42

(125 MHz, $\mathrm{C}_{6} \mathrm{D}_{6}$ )

DY-2-86C

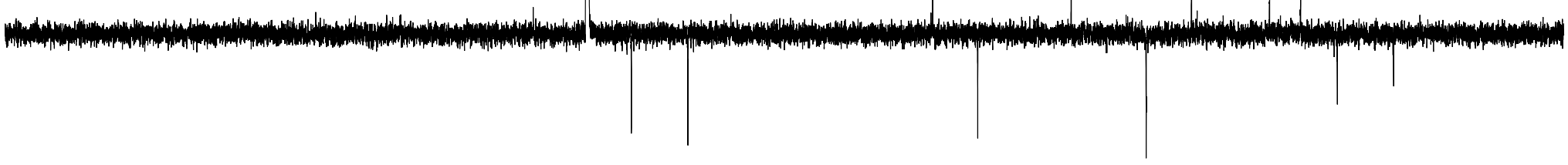




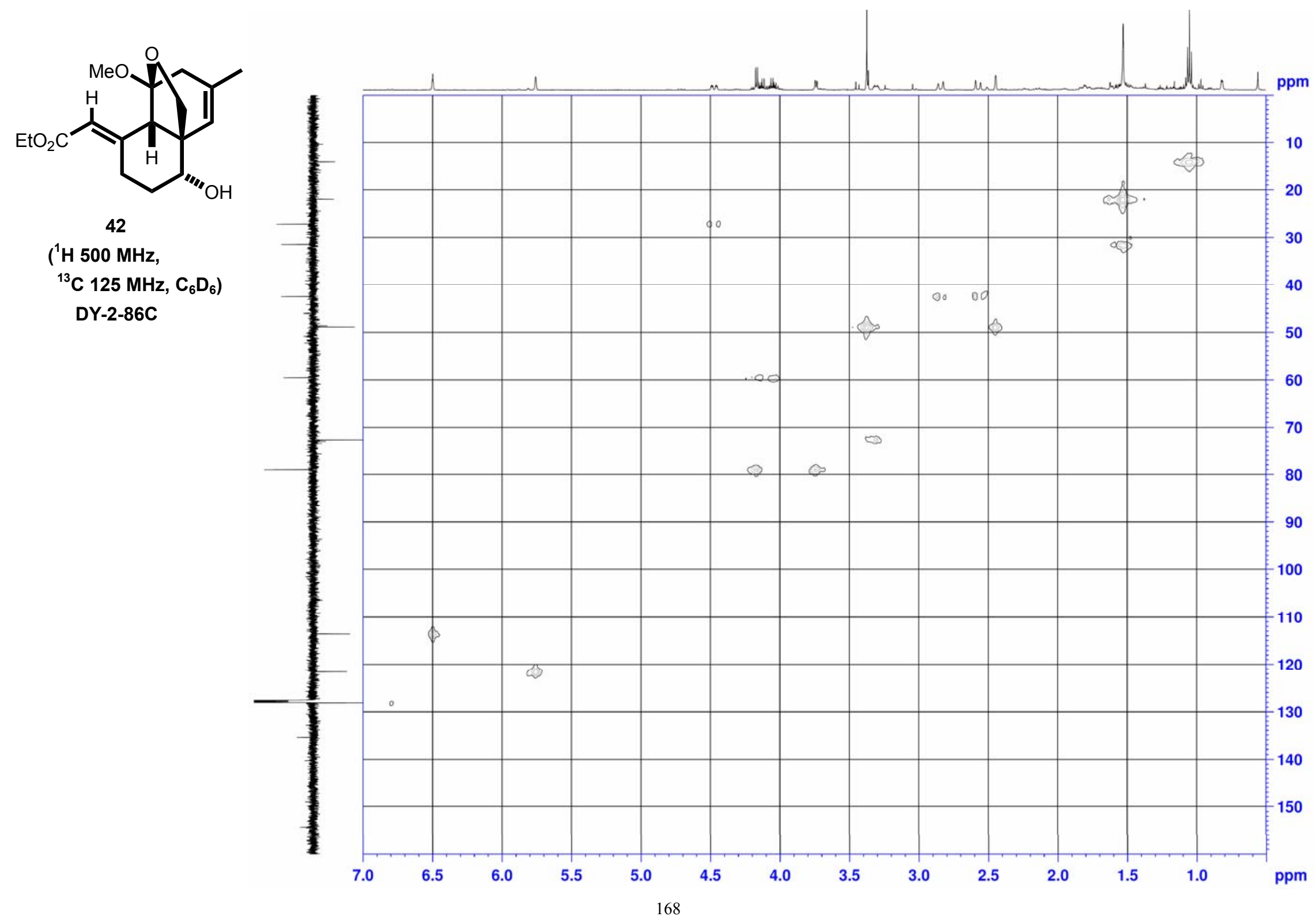




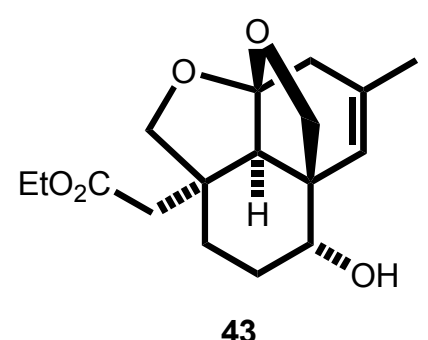

(500 MHz, $\mathrm{C}_{6} \mathrm{D}_{6}$ )

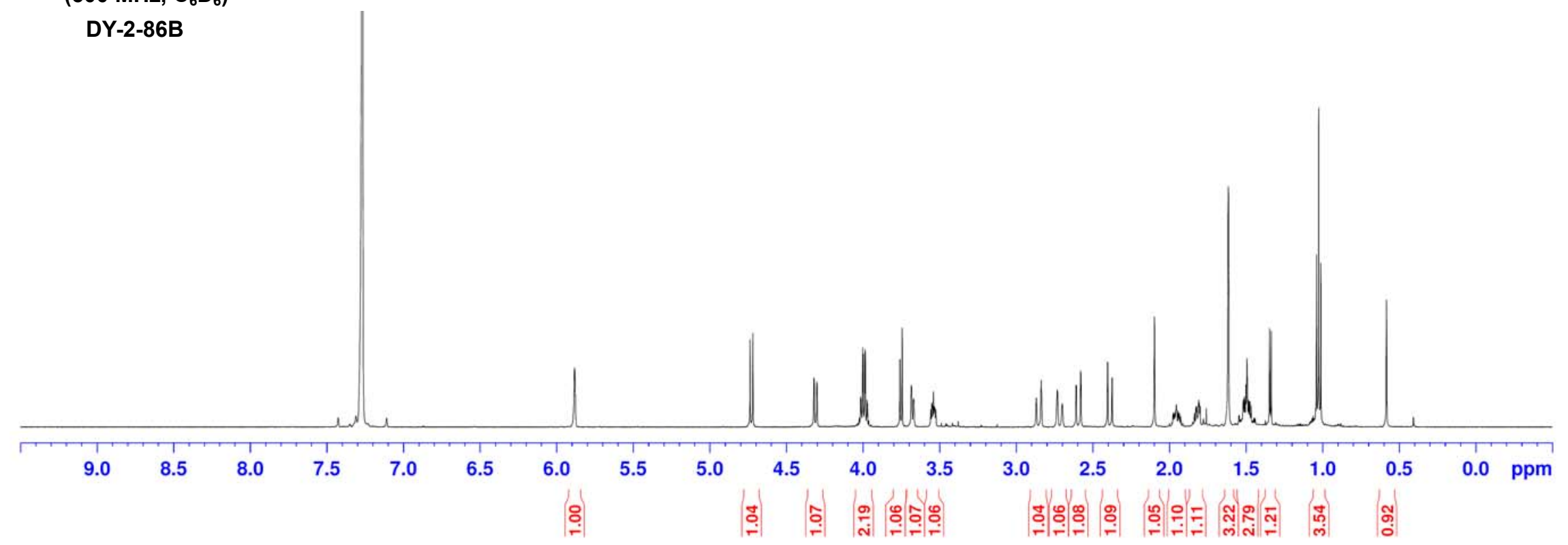




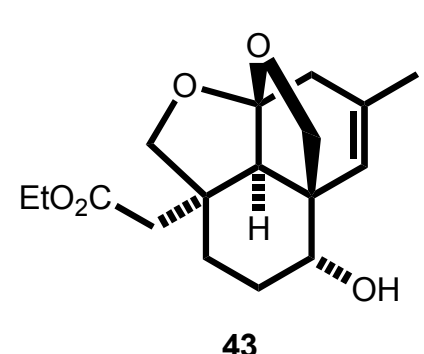

(500 MHz, $\mathrm{C}_{6} \mathrm{D}_{6}$ ) DY-2-86B

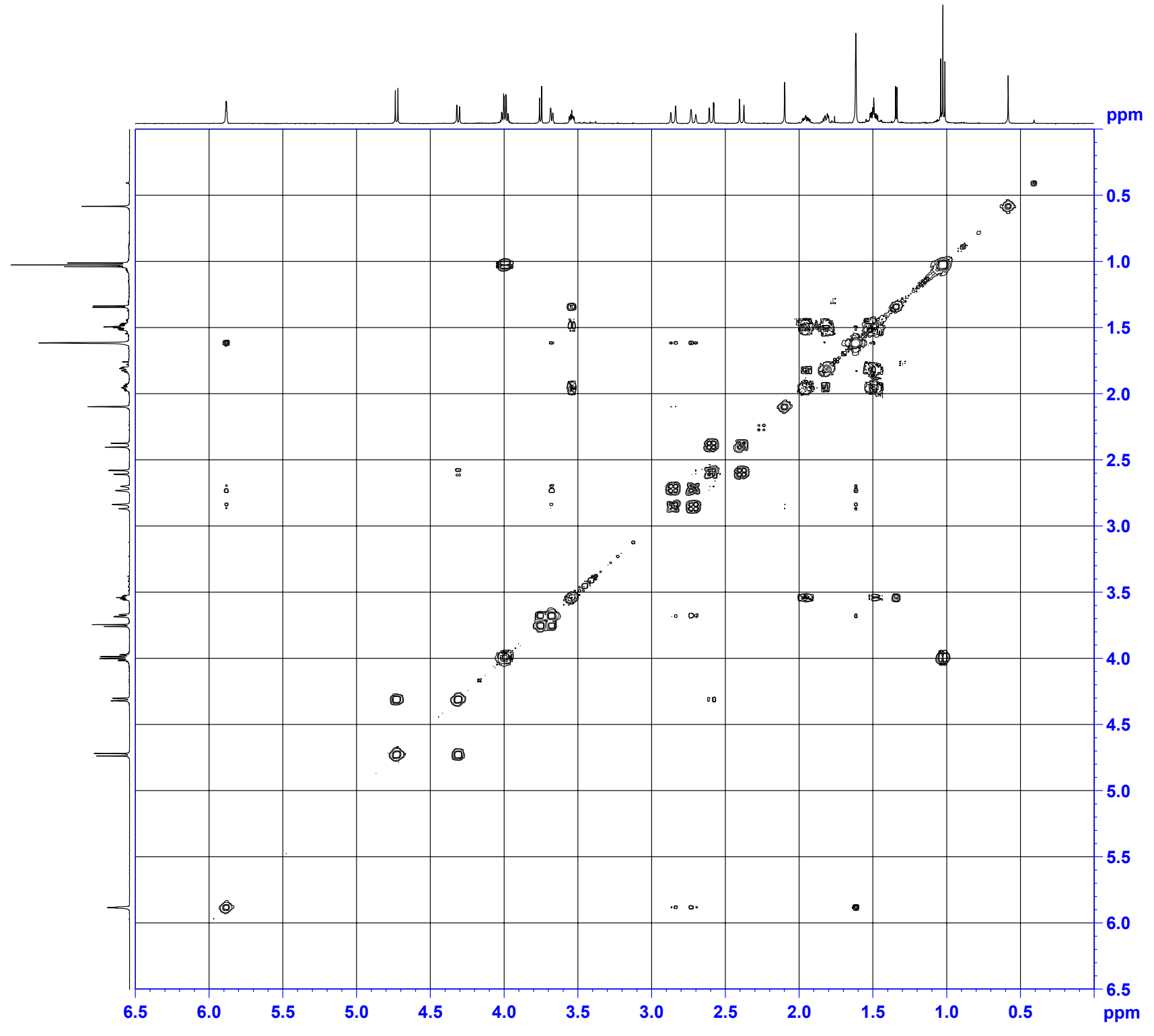

170 


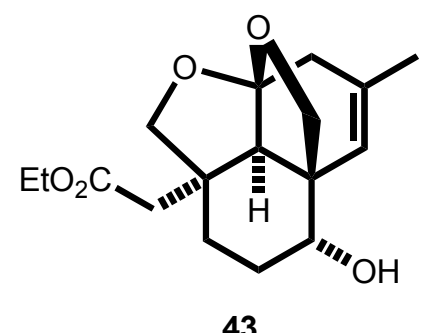

43

(125 MHz, $\mathrm{C}_{6} \mathrm{D}_{6}$ )

DY-2-86B

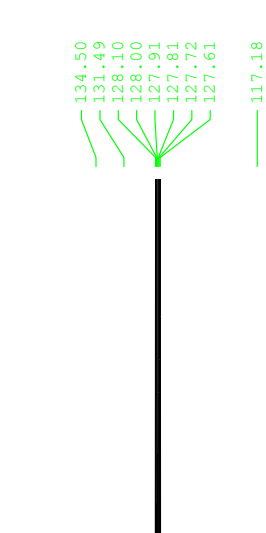

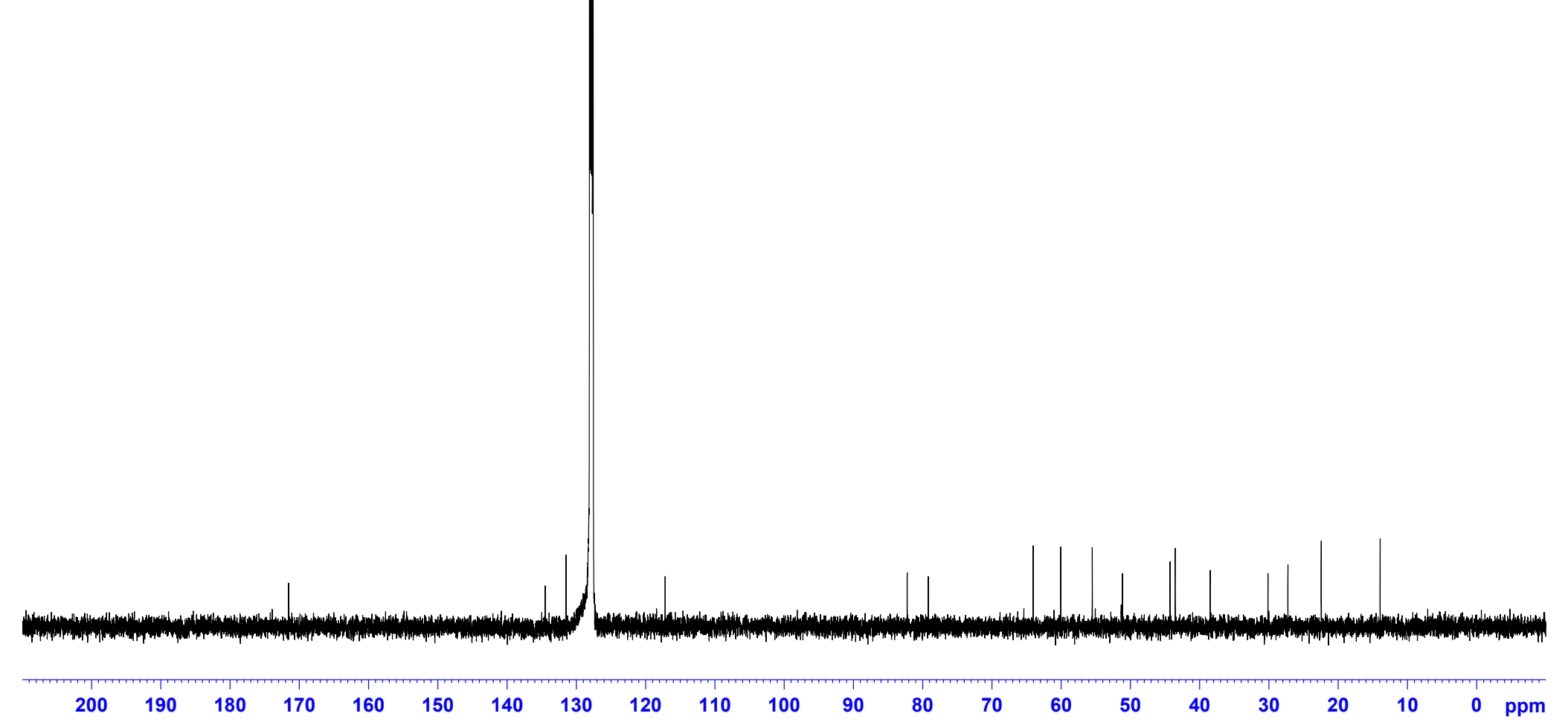




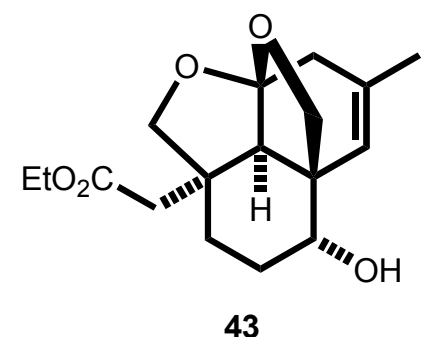

43

(125 MHz, $\mathrm{C}_{6} \mathrm{D}_{6}$ )

DY-2-86B 


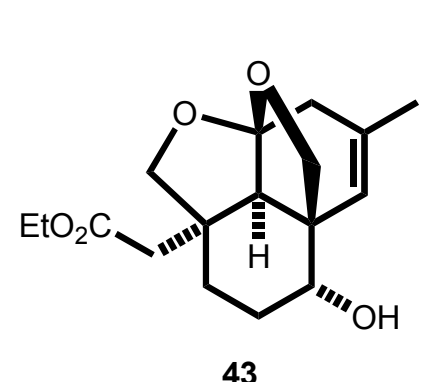

( $1 \mathrm{H} 500 \mathrm{MHz}$,

${ }^{13} \mathrm{C} 125 \mathrm{MHz}, \mathrm{C}_{6} \mathrm{D}_{6}$ ) DY-2-86B

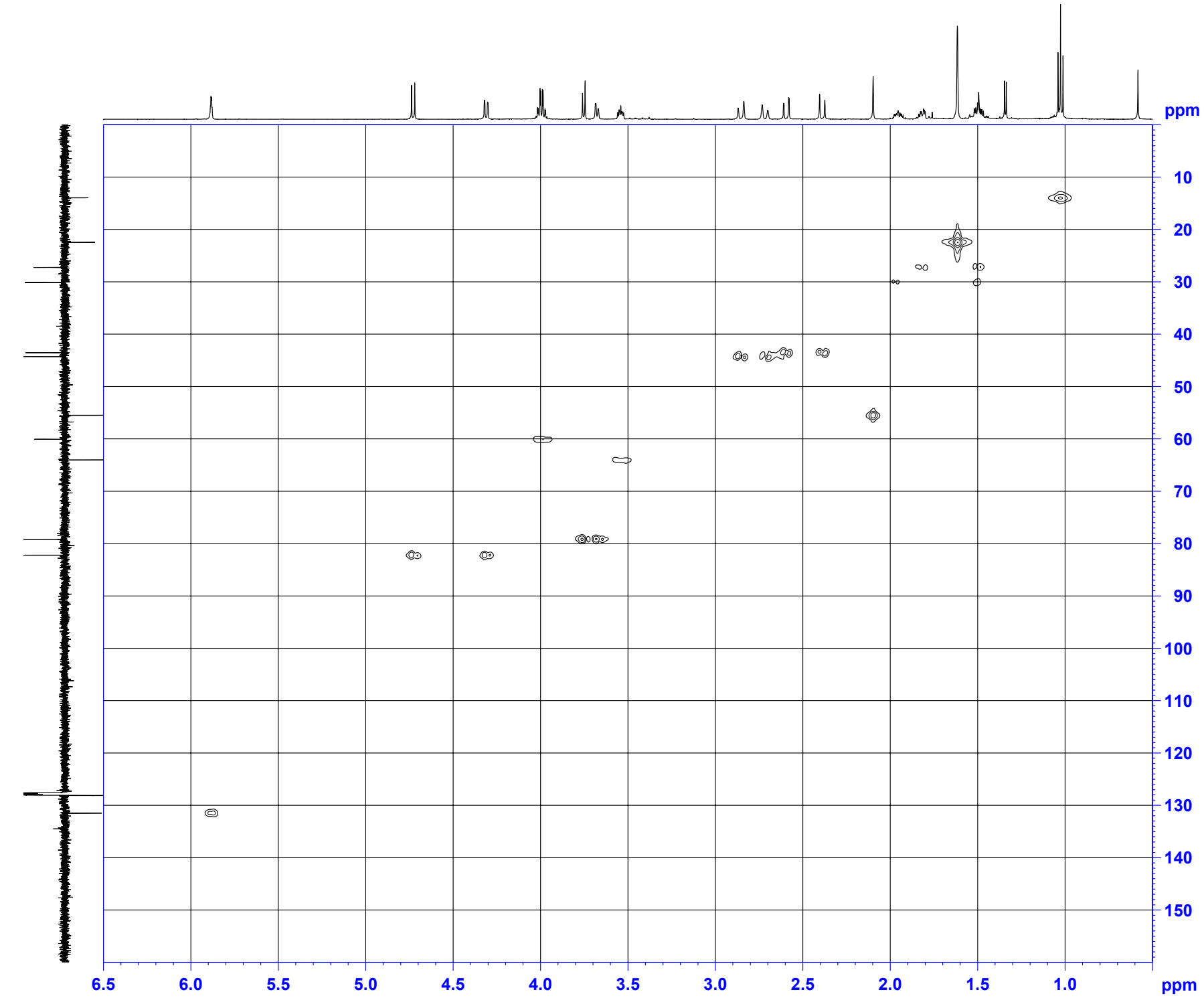




\title{
Crystallography Supporting Material
}

For

\section{“Quassinoid Support Studies: Fused Carbocycle Synthesis from Benzoic Acid Derivatives via 5-Hexynyl and 6-Heptynyl Radical Cyclizations"}

\author{
Valerie Cwynar, Matthew G. Donahue, David J. Hart* and Dexi Yang \\ Department of Chemistry, The Ohio State University, Columbus, Ohio 43210, USA
}

\section{Contents}

1. Crystallographic Details and ORTEP for Compound 26 (pages 175-184 with ORTEP on page 175)

2. Crystallographic Details and ORTEP for Compound 39

(pages 185-197 with ORTEP on page 185) 

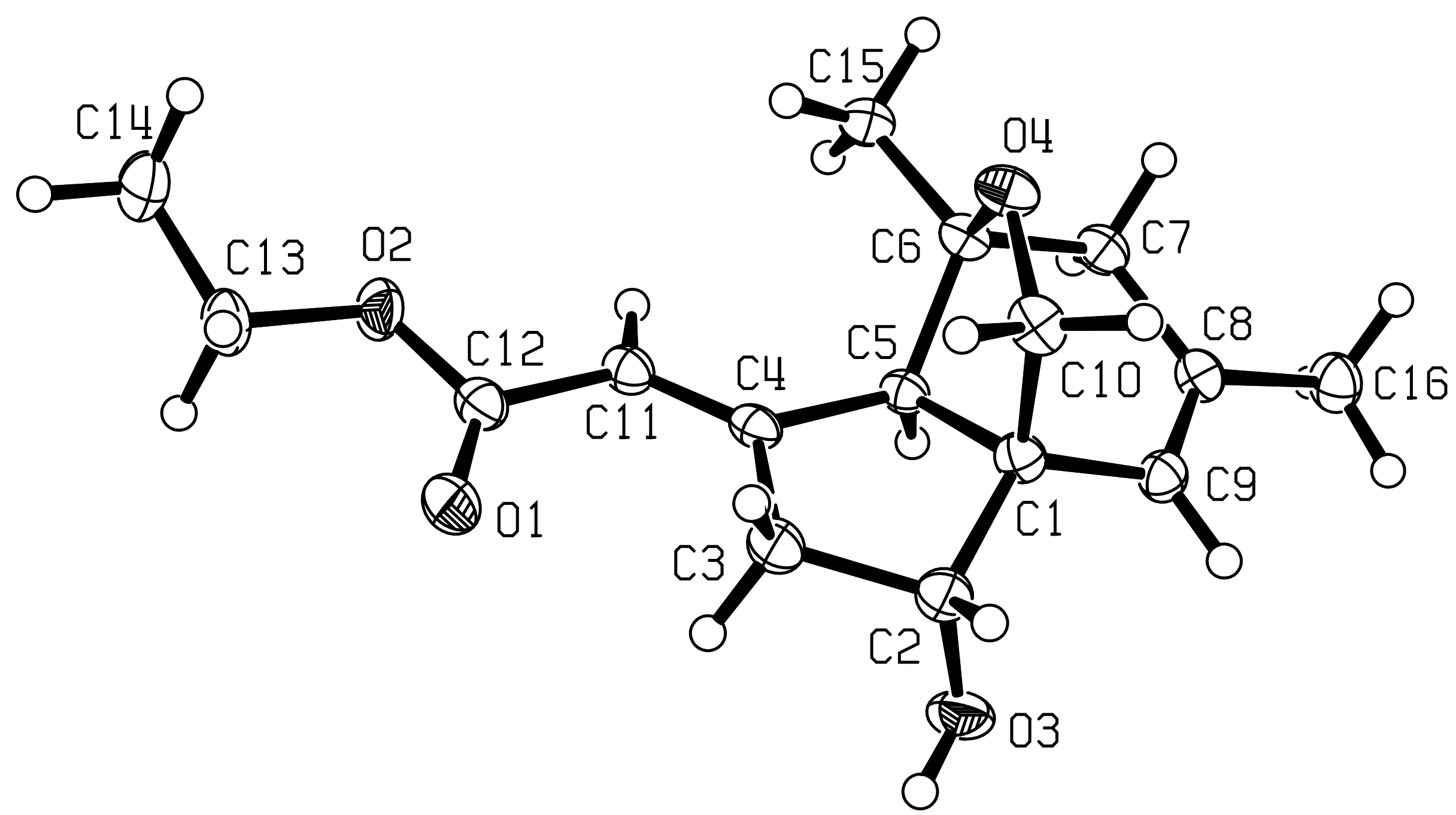
Hart 1289 (Compound 26)

The data collection crystal was a clear, colorless rectangular plate, cut from an intergrown mass of crystals. Examination of the diffraction pattern on a Nonius Kappa CCD diffractometer indicated a monoclinic crystal system.

All work was done at $150 \mathrm{~K}$ using an Oxford Cryosystems Cryostream Cooler. The data collection strategy was set up to measure

a quadrant of reciprocal space with a redundancy factor

of 4.0, which means that 90\% of the reflections were measured at least

4.0 times. A combination of phi and

omega scans with a frame width of $1.0^{\circ}$ was used.

Data integration was done with Denzo(1), and scaling and merging of the data was done with Scalepack(1).

Merging the data and averaging the symmetry equivalent reflections

resulted in an Rint value of 0.042 .

The structure was solved by the direct methods procedure in SHELXS-97(2). Full-matrix least-squares refinements based on $\mathrm{F}^{2}$ were performed in SHELXL-97(3), as incorporated in the WinGX package (4).

The hydrogen atom bonded to the oxygen atom, $O(3)$, was refined isotropically. For the methyl groups, the hydrogen atoms were added at calculated positions using a riding model with $\mathrm{U}(\mathrm{H})=1.5 * \mathrm{Ueq}$ (bonded carbon atom). The torsion angle, which defines the orientation of the methyl group about the $\mathrm{C}-\mathrm{C}$ bond, was refined. The remaining hydrogen atoms were included in the model at calculated positions using a riding model with $\mathrm{U}(\mathrm{H})=1.2 * \mathrm{Ueq}$ (attached atom). The final refinement cycle was based on 3299 intensities and 188 variables and resulted in agreement factors of $R 1(F)=0.063$ and wR2 $\left(F^{2}\right)=0.100$. For the subset of data with $I>2 *$ sigma $(I)$, the R1(F) value is 0.040 for 2452 reflections.

The final difference electron density map contains maximum and minimum peak heights of 0.30 and $-0.19 \mathrm{e} / \AA^{3}$. Neutral atom scattering factors were used and include terms for anomalous dispersion(5).

References

(1) DENZO: Otwinowski, Z. \& Minor, W., Methods in Enzymology, Vol 276: Macromolecular Crystallography, part A, 307-326, (1997), Carter, Jr., C. W. \& Sweet, R. M., Eds., Academic Press.

(2) SHELXS-97: Sheldrick, G. M., Universitat Gottingen, Germany, 1997 .

(3) SHELXL-97: Sheldrick, G. M., Universitat Gottingen, Germany, 1997.

(4) WingX-Version 1.64.05: Farrugia, L. J., J. Appl. Cryst., (1999), $32,837-838$.

(5) International Tables for Crystallography (1992) . Volume C. Dordrecht: Kluwer Academic Publishers. 
Table 1. Crystallographic details for Hart 1289 (Compound 26)

Empirical formula

Formula weight

Temperature

Wavelength

Crystal system

Space group

Unit cell dimensions

Volume

Z

Density (calculated)

Absorption coefficient

$\mathrm{F}(000)$

Crystal size

Theta range for data collection

Index ranges

Reflections collected

Independent reflections

Completeness to theta $=27.45^{\circ}$

Refinement method

Data / restraints / parameters

Goodness-of-fit on $\mathrm{F}^{2}$

Final R indices [I $>2 \operatorname{sigma}(\mathrm{I})]$

$\mathrm{R}$ indices (all data)

Largest diff. peak and hole
C16 H22 O4

278.34

150(2) K

$0.71073 \AA$

monoclinic

$\mathrm{P} 2{ }_{1} / \mathrm{c}$

$\mathrm{a}=10.543(2) \AA$

$\mathrm{b}=16.687(3) \AA$

$\mathrm{c}=8.181(1) \AA$

$\beta=91.318(7)^{\circ}$

1438.9(4) $\AA^{3}$

4

$1.285 \mathrm{Mg} / \mathrm{m}^{3}$

$0.091 \mathrm{~mm}^{-1}$

600

$0.08 \times 0.27 \times 0.38 \mathrm{~mm}^{3}$

2.29 to $27.45^{\circ}$.

$-13<=\mathrm{h}<=13,-21<=\mathrm{k}<=20,-10<=\mathrm{l}<=10$

28349

$3299[\mathrm{R}(\mathrm{int})=0.042]$

$99.9 \%$

Full-matrix least-squares on $\mathrm{F}^{2}$

3299 / 0 / 188

1.031

$\mathrm{R} 1=0.0399, \mathrm{wR} 2=0.0908$

$\mathrm{R} 1=0.0633, \mathrm{wR} 2=0.0999$

0.298 and $-0.185 \mathrm{e} / \AA^{3}$ 
Table 2. Atomic coordinates ( $\mathrm{x} 10^{4}$ ) and equivalent isotropic displacement parameters $\left(\AA^{2} \mathrm{x} 10^{3}\right)$ for Hart 1289. $\mathrm{U}(\mathrm{eq})$ is defined as one third of the trace of the orthogonalized $\mathrm{U}^{\mathrm{ij}}$ tensor.

\begin{tabular}{|c|c|c|c|c|}
\hline & $\mathrm{x}$ & $\mathrm{y}$ & $\mathrm{z}$ & $\mathrm{U}(\mathrm{eq})$ \\
\hline $\mathrm{C}(1)$ & 2517(1) & $616(1)$ & $8900(2)$ & 21(1) \\
\hline $\mathrm{C}(2)$ & 2822(1) & $208(1)$ & $7295(2)$ & $25(1)$ \\
\hline $\mathrm{C}(3)$ & 4029(1) & 641(1) & $6743(2)$ & $26(1)$ \\
\hline $\mathrm{C}(4)$ & $4679(1)$ & $958(1)$ & $8285(1)$ & 20(1) \\
\hline C(5) & 3811(1) & $814(1)$ & $9707(1)$ & 19(1) \\
\hline$C(6)$ & $3400(1)$ & 1481(1) & 10871(2) & 21(1) \\
\hline C(7) & 2655(1) & 1078(1) & $12245(2)$ & $25(1)$ \\
\hline $\mathrm{C}(8)$ & 1752(1) & $426(1)$ & 11671(2) & $22(1)$ \\
\hline C(9) & 1707(1) & 193(1) & 10118(2) & $22(1)$ \\
\hline$C(10)$ & 1991(1) & $1470(1)$ & $8603(2)$ & $26(1)$ \\
\hline$C(11)$ & $5837(1)$ & $1279(1)$ & 8399(2) & $22(1)$ \\
\hline$C(12)$ & 6636(1) & 1423(1) & $6979(2)$ & $23(1)$ \\
\hline$C(13)$ & 8433(1) & 2144(1) & $6057(2)$ & $33(1)$ \\
\hline$C(14)$ & 9256(1) & 2814(1) & $6690(2)$ & $37(1)$ \\
\hline$C(15)$ & 4401(1) & 2040(1) & 11568(2) & $28(1)$ \\
\hline$C(16)$ & 935(1) & $64(1)$ & 12957(2) & $29(1)$ \\
\hline $\mathrm{O}(1)$ & 6442(1) & 1173(1) & $5601(1)$ & $33(1)$ \\
\hline $\mathrm{O}(2)$ & 7619(1) & 1899(1) & 7383(1) & 29(1) \\
\hline $\mathrm{O}(3)$ & $3057(1)$ & $-619(1)$ & 7621(1) & $33(1)$ \\
\hline $\mathrm{O}(4)$ & 2522(1) & 1960(1) & 9884(1) & $27(1)$ \\
\hline
\end{tabular}


Table 3. Bond lengths $[\AA]$ and angles $\left[^{\circ}\right]$ for Hart 1289.

\begin{tabular}{|c|c|}
\hline $\mathrm{C}(1)-\mathrm{C}(9)$ & $1.5025(17)$ \\
\hline $\mathrm{C}(1)-\mathrm{C}(2)$ & $1.5200(17)$ \\
\hline$C(1)-C(5)$ & $1.5382(17)$ \\
\hline $\mathrm{C}(1)-\mathrm{C}(10)$ & $1.5462(18)$ \\
\hline $\mathrm{C}(2)-\mathrm{O}(3)$ & 1.4261(17) \\
\hline $\mathrm{C}(2)-\mathrm{C}(3)$ & $1.5406(18)$ \\
\hline $\mathrm{C}(2)-\mathrm{H}(2)$ & 1.0000 \\
\hline $\mathrm{C}(3)-\mathrm{C}(4)$ & $1.5171(18)$ \\
\hline C(3)-H(3A) & 0.9900 \\
\hline C(3)-H(3B) & 0.9900 \\
\hline $\mathrm{C}(4)-\mathrm{C}(11)$ & $1.3345(18)$ \\
\hline$C(4)-C(5)$ & $1.5163(16)$ \\
\hline$C(5)-C(6)$ & $1.5333(16)$ \\
\hline C(5)-H(5) & 1.0000 \\
\hline $\mathrm{C}(6)-\mathrm{O}(4)$ & $1.4539(15)$ \\
\hline$C(6)-C(15)$ & $1.5104(18)$ \\
\hline$C(6)-C(7)$ & $1.5400(17)$ \\
\hline C(7)-C(8) & $1.5131(18)$ \\
\hline $\mathrm{C}(7)-\mathrm{H}(7 \mathrm{~A})$ & 0.9900 \\
\hline $\mathrm{C}(7)-\mathrm{H}(7 \mathrm{~B})$ & 0.9900 \\
\hline $\mathrm{C}(8)-\mathrm{C}(9)$ & $1.3284(18)$ \\
\hline C(8)-C(16) & $1.5018(18)$ \\
\hline $\mathrm{C}(9)-\mathrm{H}(9)$ & 0.9500 \\
\hline $\mathrm{C}(10)-\mathrm{O}(4)$ & $1.4325(16)$ \\
\hline $\mathrm{C}(10)-\mathrm{H}(10 \mathrm{~A})$ & 0.9900 \\
\hline $\mathrm{C}(10)-\mathrm{H}(10 \mathrm{~B})$ & 0.9900 \\
\hline $\mathrm{C}(11)-\mathrm{C}(12)$ & $1.4704(17)$ \\
\hline $\mathrm{C}(11)-\mathrm{H}(11)$ & 0.9500 \\
\hline $\mathrm{C}(12)-\mathrm{O}(1)$ & $1.2146(16)$ \\
\hline $\mathrm{C}(12)-\mathrm{O}(2)$ & $1.3412(16)$ \\
\hline $\mathrm{C}(13)-\mathrm{O}(2)$ & $1.4563(15)$ \\
\hline C(13)-C(14) & $1.500(2)$ \\
\hline $\mathrm{C}(13)-\mathrm{H}(13 \mathrm{~A})$ & 0.9900 \\
\hline $\mathrm{C}(13)-\mathrm{H}(13 \mathrm{~B})$ & 0.9900 \\
\hline
\end{tabular}




\begin{tabular}{|c|c|}
\hline $\mathrm{C}(14)-\mathrm{H}(14 \mathrm{~A})$ & 0.9800 \\
\hline $\mathrm{C}(14)-\mathrm{H}(14 \mathrm{~B})$ & 0.9800 \\
\hline $\mathrm{C}(14)-\mathrm{H}(14 \mathrm{C})$ & 0.9800 \\
\hline $\mathrm{C}(15)-\mathrm{H}(15 \mathrm{~A})$ & 0.9800 \\
\hline $\mathrm{C}(15)-\mathrm{H}(15 \mathrm{~B})$ & 0.9800 \\
\hline $\mathrm{C}(15)-\mathrm{H}(15 \mathrm{C})$ & 0.9800 \\
\hline $\mathrm{C}(16)-\mathrm{H}(16 \mathrm{~A})$ & 0.9800 \\
\hline $\mathrm{C}(16)-\mathrm{H}(16 \mathrm{~B})$ & 0.9800 \\
\hline $\mathrm{C}(16)-\mathrm{H}(16 \mathrm{C})$ & 0.9800 \\
\hline $\mathrm{O}(3)-\mathrm{H}(1 \mathrm{O} 3)$ & $0.843(19)$ \\
\hline C(9)-C(1)-C(2) & $119.80(11)$ \\
\hline C(9)-C(1)-C(5) & 109.14(10) \\
\hline C(2)-C(1)-C(5) & $105.32(10)$ \\
\hline C(9)-C(1)-C(10) & $109.25(10)$ \\
\hline C(2)-C(1)-C(10) & $111.07(10)$ \\
\hline$C(5)-C(1)-C(10)$ & $100.42(10)$ \\
\hline $\mathrm{O}(3)-\mathrm{C}(2)-\mathrm{C}(1)$ & $108.13(10)$ \\
\hline $\mathrm{O}(3)-\mathrm{C}(2)-\mathrm{C}(3)$ & $111.60(11)$ \\
\hline C(1)-C(2)-C(3) & 103.61(10) \\
\hline $\mathrm{O}(3)-\mathrm{C}(2)-\mathrm{H}(2)$ & 111.1 \\
\hline $\mathrm{C}(1)-\mathrm{C}(2)-\mathrm{H}(2)$ & 111.1 \\
\hline $\mathrm{C}(3)-\mathrm{C}(2)-\mathrm{H}(2)$ & 111.1 \\
\hline $\mathrm{C}(4)-\mathrm{C}(3)-\mathrm{C}(2)$ & $106.28(10)$ \\
\hline $\mathrm{C}(4)-\mathrm{C}(3)-\mathrm{H}(3 \mathrm{~A})$ & 110.5 \\
\hline $\mathrm{C}(2)-\mathrm{C}(3)-\mathrm{H}(3 \mathrm{~A})$ & 110.5 \\
\hline $\mathrm{C}(4)-\mathrm{C}(3)-\mathrm{H}(3 \mathrm{~B})$ & 110.5 \\
\hline $\mathrm{C}(2)-\mathrm{C}(3)-\mathrm{H}(3 \mathrm{~B})$ & 110.5 \\
\hline $\mathrm{H}(3 \mathrm{~A})-\mathrm{C}(3)-\mathrm{H}(3 \mathrm{~B})$ & 108.7 \\
\hline$C(11)-C(4)-C(5)$ & $125.26(11)$ \\
\hline C(11)-C(4)-C(3) & $126.39(11)$ \\
\hline C(5)-C(4)-C(3) & $108.29(10)$ \\
\hline C(4)-C(5)-C(6) & $123.06(10)$ \\
\hline $\mathrm{C}(4)-\mathrm{C}(5)-\mathrm{C}(1)$ & $104.44(10)$ \\
\hline$C(6)-C(5)-C(1)$ & 99.31(9) \\
\hline $\mathrm{C}(4)-\mathrm{C}(5)-\mathrm{H}(5)$ & 109.6 \\
\hline
\end{tabular}




\begin{tabular}{|c|c|}
\hline $\mathrm{C}(6)-\mathrm{C}(5)-\mathrm{H}(5)$ & 109.6 \\
\hline $\mathrm{C}(1)-\mathrm{C}(5)-\mathrm{H}(5)$ & 109.6 \\
\hline $\mathrm{O}(4)-\mathrm{C}(6)-\mathrm{C}(15)$ & $107.48(10)$ \\
\hline $\mathrm{O}(4)-\mathrm{C}(6)-\mathrm{C}(5)$ & 103.85(9) \\
\hline C(15)-C(6)-C(5) & $118.52(10)$ \\
\hline $\mathrm{O}(4)-\mathrm{C}(6)-\mathrm{C}(7)$ & $108.45(10)$ \\
\hline C(15)-C(6)-C(7) & $110.97(10)$ \\
\hline $\mathrm{C}(5)-\mathrm{C}(6)-\mathrm{C}(7)$ & $107.02(10)$ \\
\hline $\mathrm{C}(8)-\mathrm{C}(7)-\mathrm{C}(6)$ & $114.51(10)$ \\
\hline $\mathrm{C}(8)-\mathrm{C}(7)-\mathrm{H}(7 \mathrm{~A})$ & 108.6 \\
\hline $\mathrm{C}(6)-\mathrm{C}(7)-\mathrm{H}(7 \mathrm{~A})$ & 108.6 \\
\hline C(8)-C(7)-H(7B) & 108.6 \\
\hline $\mathrm{C}(6)-\mathrm{C}(7)-\mathrm{H}(7 \mathrm{~B})$ & 108.6 \\
\hline $\mathrm{H}(7 \mathrm{~A})-\mathrm{C}(7)-\mathrm{H}(7 \mathrm{~B})$ & 107.6 \\
\hline C(9)-C(8)-C(16) & $122.96(12)$ \\
\hline C(9)-C(8)-C(7) & $121.03(11)$ \\
\hline C(16)-C(8)-C(7) & $116.01(11)$ \\
\hline $\mathrm{C}(8)-\mathrm{C}(9)-\mathrm{C}(1)$ & $119.25(12)$ \\
\hline $\mathrm{C}(8)-\mathrm{C}(9)-\mathrm{H}(9)$ & 120.4 \\
\hline C(1)-C(9)-H(9) & 120.4 \\
\hline $\mathrm{O}(4)-\mathrm{C}(10)-\mathrm{C}(1)$ & 106.14(10) \\
\hline $\mathrm{O}(4)-\mathrm{C}(10)-\mathrm{H}(10 \mathrm{~A})$ & 110.5 \\
\hline $\mathrm{C}(1)-\mathrm{C}(10)-\mathrm{H}(10 \mathrm{~A})$ & 110.5 \\
\hline $\mathrm{O}(4)-\mathrm{C}(10)-\mathrm{H}(10 \mathrm{~B})$ & 110.5 \\
\hline C(1)-C(10)-H(10B) & 110.5 \\
\hline $\mathrm{H}(10 \mathrm{~A})-\mathrm{C}(10)-\mathrm{H}(10 \mathrm{~B})$ & 108.7 \\
\hline C(4)-C(11)-C(12) & 123.39(12) \\
\hline $\mathrm{C}(4)-\mathrm{C}(11)-\mathrm{H}(11)$ & 118.3 \\
\hline $\mathrm{C}(12)-\mathrm{C}(11)-\mathrm{H}(11)$ & 118.3 \\
\hline $\mathrm{O}(1)-\mathrm{C}(12)-\mathrm{O}(2)$ & $123.02(12)$ \\
\hline $\mathrm{O}(1)-\mathrm{C}(12)-\mathrm{C}(11)$ & $126.09(12)$ \\
\hline $\mathrm{O}(2)-\mathrm{C}(12)-\mathrm{C}(11)$ & $110.86(11)$ \\
\hline $\mathrm{O}(2)-\mathrm{C}(13)-\mathrm{C}(14)$ & $107.35(11)$ \\
\hline $\mathrm{O}(2)-\mathrm{C}(13)-\mathrm{H}(13 \mathrm{~A})$ & 110.2 \\
\hline $\mathrm{C}(14)-\mathrm{C}(13)-\mathrm{H}(13 \mathrm{~A})$ & 110.2 \\
\hline $\mathrm{O}(2)-\mathrm{C}(13)-\mathrm{H}(13 \mathrm{~B})$ & 110.2 \\
\hline
\end{tabular}




\begin{tabular}{|c|c|}
\hline $\mathrm{C}(14)-\mathrm{C}(13)-\mathrm{H}(13 \mathrm{~B})$ & 110.2 \\
\hline $\mathrm{H}(13 \mathrm{~A})-\mathrm{C}(13)-\mathrm{H}(13 \mathrm{~B})$ & 108.5 \\
\hline $\mathrm{C}(13)-\mathrm{C}(14)-\mathrm{H}(14 \mathrm{~A})$ & 109.5 \\
\hline $\mathrm{C}(13)-\mathrm{C}(14)-\mathrm{H}(14 \mathrm{~B})$ & 109.5 \\
\hline $\mathrm{H}(14 \mathrm{~A})-\mathrm{C}(14)-\mathrm{H}(14 \mathrm{~B})$ & 109.5 \\
\hline C(13)-C(14)-H(14C) & 109.5 \\
\hline $\mathrm{H}(14 \mathrm{~A})-\mathrm{C}(14)-\mathrm{H}(14 \mathrm{C})$ & 109.5 \\
\hline H(14B)-C(14)-H(14C) & 109.5 \\
\hline $\mathrm{C}(6)-\mathrm{C}(15)-\mathrm{H}(15 \mathrm{~A})$ & 109.5 \\
\hline C(6)-C(15)-H(15B) & 109.5 \\
\hline $\mathrm{H}(15 \mathrm{~A})-\mathrm{C}(15)-\mathrm{H}(15 \mathrm{~B})$ & 109.5 \\
\hline $\mathrm{C}(6)-\mathrm{C}(15)-\mathrm{H}(15 \mathrm{C})$ & 109.5 \\
\hline $\mathrm{H}(15 \mathrm{~A})-\mathrm{C}(15)-\mathrm{H}(15 \mathrm{C})$ & 109.5 \\
\hline H(15B)-C(15)-H(15C) & 109.5 \\
\hline $\mathrm{C}(8)-\mathrm{C}(16)-\mathrm{H}(16 \mathrm{~A})$ & 109.5 \\
\hline C(8)-C(16)-H(16B) & 109.5 \\
\hline $\mathrm{H}(16 \mathrm{~A})-\mathrm{C}(16)-\mathrm{H}(16 \mathrm{~B})$ & 109.5 \\
\hline $\mathrm{C}(8)-\mathrm{C}(16)-\mathrm{H}(16 \mathrm{C})$ & 109.5 \\
\hline $\mathrm{H}(16 \mathrm{~A})-\mathrm{C}(16)-\mathrm{H}(16 \mathrm{C})$ & 109.5 \\
\hline H(16B)-C(16)-H(16C) & 109.5 \\
\hline $\mathrm{C}(12)-\mathrm{O}(2)-\mathrm{C}(13)$ & $116.60(10)$ \\
\hline $\mathrm{C}(2)-\mathrm{O}(3)-\mathrm{H}(1 \mathrm{O} 3)$ & 105.6(12) \\
\hline $\mathrm{C}(10)-\mathrm{O}(4)-\mathrm{C}(6)$ & 109.02(9) \\
\hline
\end{tabular}


Table 4. Anisotropic displacement parameters $\left(\AA^{2} \mathrm{x} 10^{3}\right)$ for Hart 1289. The anisotropic displacement factor exponent takes the form: $-2 \pi^{2}\left[h^{2} a^{* 2} U^{11}+\ldots+2 h k a^{*} b^{*} U^{12}\right]$

\begin{tabular}{|c|c|c|c|c|c|c|}
\hline & $\mathrm{U}^{11}$ & $\mathrm{U}^{22}$ & $\mathrm{U}^{33}$ & $\mathrm{U}^{23}$ & $\mathrm{U}^{13}$ & $\mathrm{U}^{12}$ \\
\hline $\mathrm{C}(1)$ & $22(1)$ & $24(1)$ & $16(1)$ & $-1(1)$ & $0(1)$ & $0(1)$ \\
\hline$C(2)$ & $28(1)$ & 29(1) & $17(1)$ & $-3(1)$ & $0(1)$ & $-3(1)$ \\
\hline C(3) & $30(1)$ & $31(1)$ & $19(1)$ & $-4(1)$ & $3(1)$ & $-2(1)$ \\
\hline$C(4)$ & $26(1)$ & $16(1)$ & $18(1)$ & $1(1)$ & $3(1)$ & $4(1)$ \\
\hline C(5) & $22(1)$ & $19(1)$ & $16(1)$ & $-1(1)$ & 1(1) & 1(1) \\
\hline$C(6)$ & $23(1)$ & $21(1)$ & $20(1)$ & $-3(1)$ & 1(1) & $3(1)$ \\
\hline$C(7)$ & $28(1)$ & $28(1)$ & 19(1) & $-4(1)$ & $4(1)$ & $0(1)$ \\
\hline C(8) & 21(1) & $24(1)$ & $22(1)$ & 1(1) & 1(1) & $3(1)$ \\
\hline C(9) & $20(1)$ & $24(1)$ & $22(1)$ & $-1(1)$ & $0(1)$ & $-1(1)$ \\
\hline$C(10)$ & $26(1)$ & $30(1)$ & 21(1) & $2(1)$ & $0(1)$ & $4(1)$ \\
\hline$C(11)$ & $25(1)$ & $22(1)$ & 17(1) & $0(1)$ & 2(1) & 2(1) \\
\hline$C(12)$ & $26(1)$ & $22(1)$ & $23(1)$ & 1(1) & $4(1)$ & $3(1)$ \\
\hline$C(13)$ & $38(1)$ & $34(1)$ & $27(1)$ & $5(1)$ & 15(1) & $-3(1)$ \\
\hline$C(14)$ & $36(1)$ & $36(1)$ & $40(1)$ & $7(1)$ & 13(1) & $-7(1)$ \\
\hline$C(15)$ & $31(1)$ & $26(1)$ & $27(1)$ & $-8(1)$ & $5(1)$ & $-3(1)$ \\
\hline $\mathrm{C}(16)$ & $28(1)$ & $35(1)$ & $23(1)$ & $1(1)$ & $4(1)$ & $-2(1)$ \\
\hline $\mathrm{O}(1)$ & $38(1)$ & $38(1)$ & $22(1)$ & $-6(1)$ & $8(1)$ & $-6(1)$ \\
\hline $\mathrm{O}(2)$ & $30(1)$ & $34(1)$ & $22(1)$ & $2(1)$ & $8(1)$ & $-8(1)$ \\
\hline $\mathrm{O}(3)$ & $48(1)$ & $27(1)$ & $24(1)$ & $-8(1)$ & $8(1)$ & $-3(1)$ \\
\hline $\mathrm{O}(4)$ & $31(1)$ & $22(1)$ & $28(1)$ & $-1(1)$ & $-1(1)$ & $7(1)$ \\
\hline
\end{tabular}


Table 5. Hydrogen coordinates ( $\left.\mathrm{x} 10^{4}\right)$ and isotropic displacement parameters $\left(\AA^{2} \times 10^{3}\right)$ for Hart 1289.

\begin{tabular}{|c|c|c|c|c|}
\hline & $\mathrm{x}$ & $\mathrm{y}$ & $\mathrm{z}$ & $\mathrm{U}(\mathrm{eq})$ \\
\hline $\mathrm{H}(2)$ & 2112 & 276 & 6474 & 30 \\
\hline $\mathrm{H}(3 \mathrm{~A})$ & 4592 & 265 & 6170 & 32 \\
\hline $\mathrm{H}(3 \mathrm{~B})$ & 3806 & 1088 & 5992 & 32 \\
\hline $\mathrm{H}(5)$ & 4122 & 342 & 10356 & 23 \\
\hline $\mathrm{H}(7 \mathrm{~A})$ & 3268 & 844 & 13047 & 30 \\
\hline $\mathrm{H}(7 \mathrm{~B})$ & 2165 & 1494 & 12817 & 30 \\
\hline $\mathrm{H}(9)$ & 1169 & -235 & 9781 & 26 \\
\hline $\mathrm{H}(10 \mathrm{~A})$ & 2247 & 1672 & 7521 & 31 \\
\hline $\mathrm{H}(10 \mathrm{~B})$ & 1054 & 1470 & 8641 & 31 \\
\hline $\mathrm{H}(11)$ & 6162 & 1421 & 9452 & 26 \\
\hline $\mathrm{H}(13 \mathrm{~A})$ & 7912 & 2327 & 5107 & 39 \\
\hline $\mathrm{H}(13 \mathrm{~B})$ & 8963 & 1688 & 5708 & 39 \\
\hline $\mathrm{H}(14 \mathrm{~A})$ & 8725 & 3279 & 6940 & 56 \\
\hline $\mathrm{H}(14 \mathrm{~B})$ & 9867 & 2963 & 5858 & 56 \\
\hline $\mathrm{H}(14 \mathrm{C})$ & 9712 & 2640 & 7684 & 56 \\
\hline $\mathrm{H}(15 \mathrm{~A})$ & 4748 & 2365 & 10686 & 42 \\
\hline $\mathrm{H}(15 \mathrm{~B})$ & 5084 & 1725 & 12088 & 42 \\
\hline $\mathrm{H}(15 \mathrm{C})$ & 4021 & 2392 & 12381 & 42 \\
\hline $\mathrm{H}(16 \mathrm{~A})$ & 426 & -371 & 12475 & 43 \\
\hline $\mathrm{H}(16 \mathrm{~B})$ & 371 & 476 & 13389 & 43 \\
\hline $\mathrm{H}(16 \mathrm{C})$ & 1475 & -149 & 13846 & 43 \\
\hline $\mathrm{H}(1 \mathrm{O})$ & 3193(16) & $-830(11)$ & $6710(20)$ & $50(5)^{*}$ \\
\hline
\end{tabular}




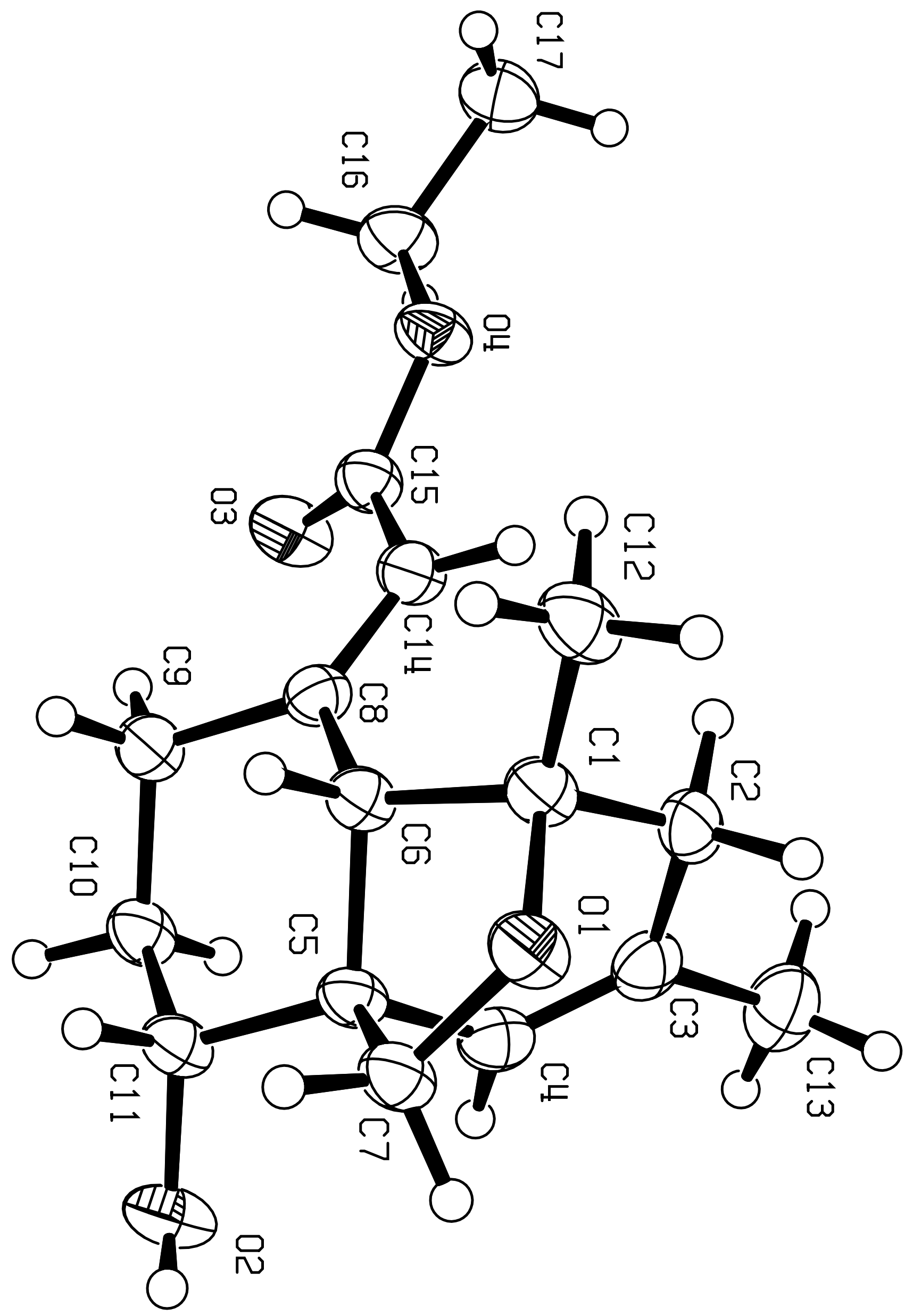


Hart 1443 (Compound 39)

The data collection crystal is best described as a colorless triangular plate cut from a large crystal. These crystals grow as stacked plates and are difficult to cut. Examination of the diffraction pattern on a Nonius Kappa CCD diffractometer indicated a monoclinic crystal system. All work was done at $150 \mathrm{~K}$ using an Oxford Cryosystems Cryostream Cooler. The data collection strategy was set up to measure a quadrant of reciprocal space with a redundancy factor of 3.6, which means that $90 \%$ of the reflections were measured at least 3. 6 times. Phi and omega scans with a frame width of $1.0^{\circ}$ were used. Data integration was done with Denzo(1), and scaling and merging of the data was done with Scalepack(1). Merging the data and averaging the symmetry equivalent reflections resulted in an Rint value of 0.039 .

The structure was solved by the direct methods procedure in SHELXS-97(2). Full-matrix least-squares refinements based on $\mathrm{F}^{2}$ were performed in SHELXL-97(3), as incorporated in the WinGX package (4).

For the methyl groups, the hydrogen atoms were added at calculated positions using a riding model with $\mathrm{U}(\mathrm{H})=1.5$ * Ueq(bonded carbon atom). The torsion angle, which defines the orientation of the methyl group about the $\mathrm{C}-\mathrm{C}$ bond, was refined. The hydroxyl hydrogen atom bonded to atom $O(2)$ was located on a difference electron density map, added to the model at that position, and isotropically refined. The remaining hydrogen atoms were included in the model at calculated positions using a riding model with $\mathrm{U}(\mathrm{H})=1.2$ * Ueq(attached atom). The final refinement cycle was based on 2730 intensities and 197 variables and resulted in agreement factors of $\mathrm{R} 1(\mathrm{~F})=0.060$ and $\mathrm{wR} 2\left(\mathrm{~F}^{2}\right)=0.124$. For the subset of data with I > 2*sigma(I), the R1(F) value is 0.046 for 2167 reflections. The final difference electron density map contains maximum and minimum peak heights of 0.21 and $-0.24 \mathrm{e} / \AA^{3}$. Neutral atom scattering factors were used and include terms for anomalous dispersion(5).

There is an intermolecular hydrogen bond between the hydroxyl hydrogen atom bonded to $O(2)$ and atom $O(3)$ in a neighboring molecule.

References

(1) DENZO: Otwinowski, Z. \& Minor, W., Methods in Enzymology, Vol 276: Macromolecular Crystallography, part A, 307-326, (1997), Carter, Jr., C. W. \& Sweet, R. M., Eds., Academic Press.

(2) SHELXS-97: Sheldrick, G. M., Universitat Gottingen, Germany, 1997 .

(3) SHELXL-97: Sheldrick, G. M., Universitat Gottingen, Germany, 1997.

(4) WinGX-Version 1.70.01: Farrugia, L. J., J. Appl. Cryst., (1999), $32,837-838$.

(5) International Tables for Crystallography (1992). Volume C. Dordrecht: Kluwer Academic Publishers. 
Table 1. Crystallographic details for Hart 1443 (Compound 39)

Empirical formula

Formula weight

Temperature

Wavelength

Crystal system

Space group

Unit cell dimensions

Volume

Z

Density (calculated)

Absorption coefficient

$\mathrm{F}(000)$

Crystal size

Theta range for data collection

Index ranges

Reflections collected

Independent reflections

Completeness to theta $=25.01^{\circ}$

Refinement method

Data / restraints / parameters

Goodness-of-fit on $\mathrm{F}^{2}$

Final R indices [I>2sigma(I)]

$\mathrm{R}$ indices (all data)

Largest diff. peak and hole
C17 H24 O4

292.36

150(2) K

$0.71073 \AA$

Monoclinic

P $21 / n$

$\mathrm{a}=9.506(3) \AA$

$\mathrm{b}=14.140(4) \AA$

$\mathrm{C}=11.524(4) \AA$

$\beta=92.52(1)^{\circ}$

1547.5(8) $\AA^{3}$

4

$1.255 \mathrm{Mg} / \mathrm{m}^{3}$

$0.088 \mathrm{~mm}^{-1}$

632

$0.12 \times 0.31 \times 0.35 \mathrm{~mm}^{3}$

2.28 to $25.01^{\circ}$

$-11<=\mathrm{h}<=11,-16<=\mathrm{k}<=16,-13<=\mathrm{l}<=13$

18976

$2730[\mathrm{R}(\mathrm{int})=0.039]$

$99.9 \%$

Full-matrix least-squares on $\mathrm{F}^{2}$

2730 / 0 / 197

1.075

$\mathrm{R} 1=0.0459, \mathrm{wR} 2=0.1146$

$\mathrm{R} 1=0.0598, \mathrm{wR} 2=0.1242$

0.208 and $-0.238 \mathrm{e} / \AA^{3}$ 
Table 2. Atomic coordinates ( $\left.\mathrm{x} 10^{4}\right)$ and equivalent isotropic displacement parameters $\left(\AA^{2} \mathrm{x} 10^{3}\right)$ for Hart 1443. $\mathrm{U}(\mathrm{eq})$ is defined as one third of the trace of the orthogonalized $\mathrm{U}^{\mathrm{ij}}$ tensor.

\begin{tabular}{|c|c|c|c|c|}
\hline & $\mathrm{x}$ & $\mathrm{y}$ & $\mathrm{z}$ & $\mathrm{U}(\mathrm{eq})$ \\
\hline $\mathrm{C}(1)$ & $5068(2)$ & 10379(1) & $-2957(1)$ & $30(1)$ \\
\hline $\mathrm{C}(2)$ & $6437(2)$ & 10167(1) & $-3549(1)$ & $33(1)$ \\
\hline $\mathrm{C}(3)$ & $7307(2)$ & 11039(1) & $-3735(1)$ & $34(1)$ \\
\hline C(4) & 6904(2) & 11873(1) & $-3343(1)$ & $32(1)$ \\
\hline C(5) & $5541(2)$ & $12000(1)$ & $-2722(1)$ & $27(1)$ \\
\hline C(6) & $5265(2)$ & $11107(1)$ & $-1981(1)$ & $27(1)$ \\
\hline C(7) & 4299(2) & 11896(1) & $-3601(1)$ & $31(1)$ \\
\hline C(8) & $6318(2)$ & 11019(1) & $-970(1)$ & $28(1)$ \\
\hline C(9) & $6320(2)$ & 11907(1) & $-239(1)$ & $31(1)$ \\
\hline$C(10)$ & 6594(2) & 12795(1) & $-954(1)$ & $32(1)$ \\
\hline$C(11)$ & $5538(2)$ & 12892(1) & $-1977(1)$ & $30(1)$ \\
\hline$C(12)$ & $4292(2)$ & $9482(1)$ & $-2659(2)$ & $37(1)$ \\
\hline$C(13)$ & $8620(2)$ & 10890(2) & $-4390(2)$ & $47(1)$ \\
\hline$C(14)$ & 7066(2) & 10242(1) & $-719(1)$ & $30(1)$ \\
\hline$C(15)$ & $8078(2)$ & 10141(1) & 285(1) & $31(1)$ \\
\hline$C(16)$ & $9114(2)$ & $9043(1)$ & $1629(2)$ & $40(1)$ \\
\hline $\mathrm{C}(17)$ & $9227(2)$ & 7993(1) & 1731(2) & $46(1)$ \\
\hline $\mathrm{O}(1)$ & $4137(1)$ & 10895(1) & $-3780(1)$ & $34(1)$ \\
\hline $\mathrm{O}(2)$ & $5895(1)$ & 13723(1) & $-2598(1)$ & $39(1)$ \\
\hline $\mathrm{O}(3)$ & $8755(1)$ & 10773(1) & 751(1) & $41(1)$ \\
\hline $\mathrm{O}(4)$ & 8175(1) & $9239(1)$ & $625(1)$ & $35(1)$ \\
\hline
\end{tabular}


Table 3. Bond lengths $[\AA]$ and angles $\left[{ }^{\circ}\right]$ for Hart 1443

\begin{tabular}{|c|c|}
\hline $\mathrm{C}(1)-\mathrm{O}(1)$ & $1.463(2)$ \\
\hline $\mathrm{C}(1)-\mathrm{C}(12)$ & $1.515(2)$ \\
\hline $\mathrm{C}(1)-\mathrm{C}(2)$ & $1.526(2)$ \\
\hline$C(1)-C(6)$ & $1.530(2)$ \\
\hline $\mathrm{C}(2)-\mathrm{C}(3)$ & $1.504(2)$ \\
\hline $\mathrm{C}(2)-\mathrm{H}(2 \mathrm{~A})$ & 0.9900 \\
\hline $\mathrm{C}(2)-\mathrm{H}(2 \mathrm{~B})$ & 0.9900 \\
\hline $\mathrm{C}(3)-\mathrm{C}(4)$ & $1.326(2)$ \\
\hline C(3)-C(13) & $1.501(2)$ \\
\hline$C(4)-C(5)$ & $1.518(2)$ \\
\hline $\mathrm{C}(4)-\mathrm{H}(4)$ & 0.9500 \\
\hline $\mathrm{C}(5)-\mathrm{C}(11)$ & $1.525(2)$ \\
\hline$C(5)-C(7)$ & $1.530(2)$ \\
\hline$C(5)-C(6)$ & $1.553(2)$ \\
\hline$C(6)-C(8)$ & $1.507(2)$ \\
\hline $\mathrm{C}(6)-\mathrm{H}(6)$ & 1.0000 \\
\hline $\mathrm{C}(7)-\mathrm{O}(1)$ & $1.4383(19)$ \\
\hline $\mathrm{C}(7)-\mathrm{H}(7 \mathrm{~A})$ & 0.9900 \\
\hline $\mathrm{C}(7)-\mathrm{H}(7 \mathrm{~B})$ & 0.9900 \\
\hline C(8)-C(14) & $1.333(2)$ \\
\hline $\mathrm{C}(8)-\mathrm{C}(9)$ & $1.513(2)$ \\
\hline C(9)-C(10) & $1.529(2)$ \\
\hline C(9)-H(9A) & 0.9900 \\
\hline C(9)-H(9B) & 0.9900 \\
\hline $\mathrm{C}(10)-\mathrm{C}(11)$ & $1.521(2)$ \\
\hline $\mathrm{C}(10)-\mathrm{H}(10 \mathrm{~A})$ & 0.9900 \\
\hline $\mathrm{C}(10)-\mathrm{H}(10 \mathrm{~B})$ & 0.9900 \\
\hline $\mathrm{C}(11)-\mathrm{O}(2)$ & $1.4244(19)$ \\
\hline $\mathrm{C}(11)-\mathrm{H}(11)$ & 1.0000 \\
\hline $\mathrm{C}(12)-\mathrm{H}(12 \mathrm{~A})$ & 0.9800 \\
\hline $\mathrm{C}(12)-\mathrm{H}(12 \mathrm{~B})$ & 0.9800 \\
\hline $\mathrm{C}(12)-\mathrm{H}(12 \mathrm{C})$ & 0.9800 \\
\hline $\mathrm{C}(13)-\mathrm{H}(13 \mathrm{~A})$ & 0.9800 \\
\hline $\mathrm{C}(13)-\mathrm{H}(13 \mathrm{~B})$ & 0.9800 \\
\hline
\end{tabular}




\begin{tabular}{|c|c|}
\hline C(13)-H(13C) & 0.9800 \\
\hline$C(14)-C(15)$ & $1.479(2)$ \\
\hline C(14)-H(14) & 0.9500 \\
\hline $\mathrm{C}(15)-\mathrm{O}(3)$ & $1.2130(19)$ \\
\hline $\mathrm{C}(15)-\mathrm{O}(4)$ & $1.336(2)$ \\
\hline $\mathrm{C}(16)-\mathrm{O}(4)$ & $1.4560(19)$ \\
\hline C(16)-C(17) & $1.493(2)$ \\
\hline $\mathrm{C}(16)-\mathrm{H}(16 \mathrm{~A})$ & 0.9900 \\
\hline $\mathrm{C}(16)-\mathrm{H}(16 \mathrm{~B})$ & 0.9900 \\
\hline $\mathrm{C}(17)-\mathrm{H}(17 \mathrm{~A})$ & 0.9800 \\
\hline $\mathrm{C}(17)-\mathrm{H}(17 \mathrm{~B})$ & 0.9800 \\
\hline C(17)-H(17C) & 0.9800 \\
\hline $\mathrm{O}(2)-\mathrm{H}(1 \mathrm{O} 2)$ & $0.85(2)$ \\
\hline $\mathrm{O}(1)-\mathrm{C}(1)-\mathrm{C}(12)$ & $106.10(12)$ \\
\hline $\mathrm{O}(1)-\mathrm{C}(1)-\mathrm{C}(2)$ & 108.15(12) \\
\hline $\mathrm{C}(12)-\mathrm{C}(1)-\mathrm{C}(2)$ & 111.72(13) \\
\hline $\mathrm{O}(1)-\mathrm{C}(1)-\mathrm{C}(6)$ & $101.15(12)$ \\
\hline $\mathrm{C}(12)-\mathrm{C}(1)-\mathrm{C}(6)$ & $116.24(13)$ \\
\hline $\mathrm{C}(2)-\mathrm{C}(1)-\mathrm{C}(6)$ & $112.42(12)$ \\
\hline C(3)-C(2)-C(1) & $112.84(13)$ \\
\hline $\mathrm{C}(3)-\mathrm{C}(2)-\mathrm{H}(2 \mathrm{~A})$ & 109.0 \\
\hline $\mathrm{C}(1)-\mathrm{C}(2)-\mathrm{H}(2 \mathrm{~A})$ & 109.0 \\
\hline $\mathrm{C}(3)-\mathrm{C}(2)-\mathrm{H}(2 \mathrm{~B})$ & 109.0 \\
\hline $\mathrm{C}(1)-\mathrm{C}(2)-\mathrm{H}(2 \mathrm{~B})$ & 109.0 \\
\hline $\mathrm{H}(2 \mathrm{~A})-\mathrm{C}(2)-\mathrm{H}(2 \mathrm{~B})$ & 107.8 \\
\hline C(4)-C(3)-C(13) & 123.73(16) \\
\hline$C(4)-C(3)-C(2)$ & $120.74(15)$ \\
\hline C(13)-C(3)-C(2) & $115.53(15)$ \\
\hline$C(3)-C(4)-C(5)$ & 122.11(15) \\
\hline $\mathrm{C}(3)-\mathrm{C}(4)-\mathrm{H}(4)$ & 118.9 \\
\hline $\mathrm{C}(5)-\mathrm{C}(4)-\mathrm{H}(4)$ & 118.9 \\
\hline $\mathrm{C}(4)-\mathrm{C}(5)-\mathrm{C}(11)$ & $112.72(13)$ \\
\hline C(4)-C(5)-C(7) & 109.02(13) \\
\hline C(11)-C(5)-C(7) & $115.59(12)$ \\
\hline$C(4)-C(5)-C(6)$ & 109.35(12) \\
\hline
\end{tabular}




\begin{tabular}{|c|c|}
\hline$C(11)-C(5)-C(6)$ & $110.99(13)$ \\
\hline $\mathrm{C}(7)-\mathrm{C}(5)-\mathrm{C}(6)$ & $98.15(12)$ \\
\hline$C(8)-C(6)-C(1)$ & 124.63(13) \\
\hline $\mathrm{C}(8)-\mathrm{C}(6)-\mathrm{C}(5)$ & $111.69(12)$ \\
\hline C(1)-C(6)-C(5) & $99.24(12)$ \\
\hline $\mathrm{C}(8)-\mathrm{C}(6)-\mathrm{H}(6)$ & 106.7 \\
\hline $\mathrm{C}(1)-\mathrm{C}(6)-\mathrm{H}(6)$ & 106.7 \\
\hline $\mathrm{C}(5)-\mathrm{C}(6)-\mathrm{H}(6)$ & 106.7 \\
\hline $\mathrm{O}(1)-\mathrm{C}(7)-\mathrm{C}(5)$ & 105.33(11) \\
\hline $\mathrm{O}(1)-\mathrm{C}(7)-\mathrm{H}(7 \mathrm{~A})$ & 110.7 \\
\hline $\mathrm{C}(5)-\mathrm{C}(7)-\mathrm{H}(7 \mathrm{~A})$ & 110.7 \\
\hline $\mathrm{O}(1)-\mathrm{C}(7)-\mathrm{H}(7 \mathrm{~B})$ & 110.7 \\
\hline $\mathrm{C}(5)-\mathrm{C}(7)-\mathrm{H}(7 \mathrm{~B})$ & 110.7 \\
\hline H(7A)-C(7)-H(7B) & 108.8 \\
\hline C(14)-C(8)-C(6) & $124.48(14)$ \\
\hline$C(14)-C(8)-C(9)$ & $125.13(14)$ \\
\hline $\mathrm{C}(6)-\mathrm{C}(8)-\mathrm{C}(9)$ & $110.24(13)$ \\
\hline C(8)-C(9)-C(10) & $112.18(13)$ \\
\hline C(8)-C(9)-H(9A) & 109.2 \\
\hline $\mathrm{C}(10)-\mathrm{C}(9)-\mathrm{H}(9 \mathrm{~A})$ & 109.2 \\
\hline C(8)-C(9)-H(9B) & 109.2 \\
\hline $\mathrm{C}(10)-\mathrm{C}(9)-\mathrm{H}(9 \mathrm{~B})$ & 109.2 \\
\hline H(9A)-C(9)-H(9B) & 107.9 \\
\hline C(11)-C(10)-C(9) & $111.67(13)$ \\
\hline $\mathrm{C}(11)-\mathrm{C}(10)-\mathrm{H}(10 \mathrm{~A})$ & 109.3 \\
\hline C(9)-C(10)-H(10A) & 109.3 \\
\hline $\mathrm{C}(11)-\mathrm{C}(10)-\mathrm{H}(10 \mathrm{~B})$ & 109.3 \\
\hline $\mathrm{C}(9)-\mathrm{C}(10)-\mathrm{H}(10 \mathrm{~B})$ & 109.3 \\
\hline $\mathrm{H}(10 \mathrm{~A})-\mathrm{C}(10)-\mathrm{H}(10 \mathrm{~B})$ & 107.9 \\
\hline $\mathrm{O}(2)-\mathrm{C}(11)-\mathrm{C}(10)$ & $107.50(12)$ \\
\hline $\mathrm{O}(2)-\mathrm{C}(11)-\mathrm{C}(5)$ & $113.09(13)$ \\
\hline C(10)-C(11)-C(5) & $110.10(12)$ \\
\hline $\mathrm{O}(2)-\mathrm{C}(11)-\mathrm{H}(11)$ & 108.7 \\
\hline $\mathrm{C}(10)-\mathrm{C}(11)-\mathrm{H}(11)$ & 108.7 \\
\hline $\mathrm{C}(5)-\mathrm{C}(11)-\mathrm{H}(11)$ & 108.7 \\
\hline $\mathrm{C}(1)-\mathrm{C}(12)-\mathrm{H}(12 \mathrm{~A})$ & 109.5 \\
\hline
\end{tabular}




$\begin{array}{ll}\mathrm{C}(1)-\mathrm{C}(12)-\mathrm{H}(12 \mathrm{~B}) & 109.5 \\ \mathrm{H}(12 \mathrm{~A})-\mathrm{C}(12)-\mathrm{H}(12 \mathrm{~B}) & 109.5 \\ \mathrm{C}(1)-\mathrm{C}(12)-\mathrm{H}(12 \mathrm{C}) & 109.5 \\ \mathrm{H}(12 \mathrm{~A})-\mathrm{C}(12)-\mathrm{H}(12 \mathrm{C}) & 109.5 \\ \mathrm{H}(12 \mathrm{~B})-\mathrm{C}(12)-\mathrm{H}(12 \mathrm{C}) & 109.5 \\ \mathrm{C}(3)-\mathrm{C}(13)-\mathrm{H}(13 \mathrm{~A}) & 109.5 \\ \mathrm{C}(3)-\mathrm{C}(13)-\mathrm{H}(13 \mathrm{~B}) & 109.5 \\ \mathrm{H}(13 \mathrm{~A})-\mathrm{C}(13)-\mathrm{H}(13 \mathrm{~B}) & 109.5 \\ \mathrm{C}(3)-\mathrm{C}(13)-\mathrm{H}(13 \mathrm{C}) & 109.5 \\ \mathrm{H}(13 \mathrm{~A})-\mathrm{C}(13)-\mathrm{H}(13 \mathrm{C}) & 109.5 \\ \mathrm{H}(13 \mathrm{~B})-\mathrm{C}(13)-\mathrm{H}(13 \mathrm{C}) & 109.5 \\ \mathrm{C}(8)-\mathrm{C}(14)-\mathrm{C}(15) & 124.91(14) \\ \mathrm{C}(8)-\mathrm{C}(14)-\mathrm{H}(14) & 117.5 \\ \mathrm{C}(15)-\mathrm{C}(14)-\mathrm{H}(14) & 117.5 \\ \mathrm{O}(3)-\mathrm{C}(15)-\mathrm{O}(4) & 123.05(14) \\ \mathrm{O}(3)-\mathrm{C}(15)-\mathrm{C}(14) & 126.10(14) \\ \mathrm{O}(4)-\mathrm{C}(15)-\mathrm{C}(14) & 110.84(13) \\ \mathrm{O}(4)-\mathrm{C}(16)-\mathrm{C}(17) & 106.96(14) \\ \mathrm{O}(4)-\mathrm{C}(16)-\mathrm{H}(16 \mathrm{~A}) & 110.3 \\ \mathrm{C}(17)-\mathrm{C}(16)-\mathrm{H}(16 \mathrm{~A}) & 110.3 \\ \mathrm{O}(4)-\mathrm{C}(16)-\mathrm{H}(16 \mathrm{~B}) & 110.3 \\ \mathrm{C}(17)-\mathrm{C}(16)-\mathrm{H}(16 B) & 110.3 \\ \mathrm{H}(16 \mathrm{~A})-\mathrm{C}(16)-\mathrm{H}(16 \mathrm{~B}) & 108.6 \\ \mathrm{C}(16)-\mathrm{C}(17)-\mathrm{H}(17 \mathrm{~A}) & 109.5 \\ \mathrm{C}(16)-\mathrm{C}(17)-\mathrm{H}(17 \mathrm{~B}) & 109.5 \\ \mathrm{H}(17 \mathrm{~A})-\mathrm{C}(17)-\mathrm{H}(17 \mathrm{~B}) & 109.5 \\ \mathrm{C}(16)-\mathrm{C}(17)-\mathrm{H}(17 \mathrm{C}) & 109.5 \\ \mathrm{H}(17 \mathrm{~A})-\mathrm{C}(17)-\mathrm{H}(17 \mathrm{C}) & 109.5 \\ \mathrm{H}(17 \mathrm{~B})-\mathrm{C}(17)-\mathrm{H}(17 \mathrm{C}) & 109.5 \\ \mathrm{C}(7)-\mathrm{O}(1)-\mathrm{C}(1) & 109.84(11) \\ \mathrm{C}(11)-\mathrm{O}(2)-\mathrm{H}(1 \mathrm{O} 2) & 108.4(15) \\ \mathrm{C}(15)-\mathrm{O}(4)-\mathrm{C}(16) & 116.53(12) \\ & \end{array}$


Table 4. Anisotropic displacement parameters $\left(\AA^{2} \times 10^{3}\right)$ for Hart 1443. The anisotropic displacement factor exponent takes the form: $-2 \pi^{2}\left[h^{2} a^{* 2} U^{11}+\ldots+2 h k a^{*} b^{*} U^{12}\right]$

\begin{tabular}{|c|c|c|c|c|c|c|}
\hline & $\mathrm{U}^{11}$ & $\mathrm{U}^{22}$ & $\mathrm{U}^{33}$ & $\mathrm{U}^{23}$ & $\mathrm{U}^{13}$ & $\mathrm{U}^{12}$ \\
\hline C(1) & $34(1)$ & $26(1)$ & $28(1)$ & $-1(1)$ & $-8(1)$ & $1(1)$ \\
\hline$C(2)$ & $43(1)$ & $31(1)$ & $25(1)$ & $-5(1)$ & $-6(1)$ & $6(1)$ \\
\hline C(3) & $37(1)$ & $40(1)$ & $24(1)$ & $1(1)$ & $-3(1)$ & $3(1)$ \\
\hline C(4) & $35(1)$ & $33(1)$ & $29(1)$ & $4(1)$ & $-4(1)$ & $-3(1)$ \\
\hline C(5) & $31(1)$ & $23(1)$ & $27(1)$ & $2(1)$ & $-6(1)$ & $1(1)$ \\
\hline C(6) & $28(1)$ & $24(1)$ & $28(1)$ & $0(1)$ & $-3(1)$ & $0(1)$ \\
\hline C(7) & $37(1)$ & $25(1)$ & $31(1)$ & $1(1)$ & $-7(1)$ & $2(1)$ \\
\hline C(8) & $32(1)$ & $27(1)$ & $24(1)$ & $1(1)$ & $-1(1)$ & $-3(1)$ \\
\hline C(9) & $37(1)$ & $29(1)$ & $28(1)$ & $-2(1)$ & $-6(1)$ & 2(1) \\
\hline$C(10)$ & $38(1)$ & $25(1)$ & $32(1)$ & $-3(1)$ & $-7(1)$ & $-1(1)$ \\
\hline$C(11)$ & $34(1)$ & $22(1)$ & $33(1)$ & $1(1)$ & $-4(1)$ & $0(1)$ \\
\hline$C(12)$ & $44(1)$ & $27(1)$ & $40(1)$ & $-3(1)$ & $-8(1)$ & $-3(1)$ \\
\hline$C(13)$ & $45(1)$ & $59(1)$ & $39(1)$ & $-4(1)$ & $7(1)$ & $6(1)$ \\
\hline$C(14)$ & $37(1)$ & $26(1)$ & $27(1)$ & $0(1)$ & $-4(1)$ & $-2(1)$ \\
\hline$C(15)$ & $32(1)$ & $28(1)$ & $31(1)$ & $2(1)$ & $-2(1)$ & 2(1) \\
\hline$C(16)$ & $43(1)$ & $39(1)$ & $35(1)$ & $8(1)$ & $-12(1)$ & $6(1)$ \\
\hline$C(17)$ & $53(1)$ & $41(1)$ & $44(1)$ & $9(1)$ & $-3(1)$ & $14(1)$ \\
\hline $\mathrm{O}(1)$ & $40(1)$ & $28(1)$ & $32(1)$ & $-3(1)$ & $-14(1)$ & 2(1) \\
\hline $\mathrm{O}(2)$ & $46(1)$ & $25(1)$ & $44(1)$ & $8(1)$ & $-16(1)$ & $-4(1)$ \\
\hline $\mathrm{O}(3)$ & $47(1)$ & $33(1)$ & $43(1)$ & $0(1)$ & $-18(1)$ & $-3(1)$ \\
\hline $\mathrm{O}(4)$ & $40(1)$ & $28(1)$ & $35(1)$ & $5(1)$ & $-10(1)$ & $3(1)$ \\
\hline
\end{tabular}


Table 5. Hydrogen coordinates ( $\left.\mathrm{x} 10^{4}\right)$ and isotropic displacement parameters $\left(\AA^{2} \times 10^{3}\right)$ for Hart 1443.

\begin{tabular}{|c|c|c|c|c|}
\hline & $\mathrm{x}$ & $\mathrm{y}$ & $\mathrm{z}$ & $\mathrm{U}(\mathrm{eq})$ \\
\hline $\mathrm{H}(2 \mathrm{~A})$ & 6998 & 9713 & -3067 & 40 \\
\hline $\mathrm{H}(2 \mathrm{~B})$ & 6213 & 9865 & -4309 & 40 \\
\hline $\mathrm{H}(4)$ & 7486 & 12408 & -3455 & 39 \\
\hline $\mathrm{H}(6)$ & 4322 & 11196 & -1644 & 32 \\
\hline $\mathrm{H}(7 \mathrm{~A})$ & 3433 & 12171 & -3292 & 38 \\
\hline $\mathrm{H}(7 \mathrm{~B})$ & 4498 & 12218 & -4339 & 38 \\
\hline $\mathrm{H}(9 \mathrm{~A})$ & 7055 & 11853 & 393 & 38 \\
\hline H(9B) & 5399 & 11970 & 122 & 38 \\
\hline $\mathrm{H}(10 \mathrm{~A})$ & 6537 & 13359 & -450 & 38 \\
\hline $\mathrm{H}(10 \mathrm{~B})$ & 7558 & 12765 & -1245 & 38 \\
\hline $\mathrm{H}(11)$ & 4577 & 12976 & -1672 & 36 \\
\hline $\mathrm{H}(12 \mathrm{~A})$ & 3394 & 9645 & -2324 & 56 \\
\hline $\mathrm{H}(12 \mathrm{~B})$ & 4866 & 9113 & -2096 & 56 \\
\hline $\mathrm{H}(12 \mathrm{C})$ & 4114 & 9107 & -3366 & 56 \\
\hline $\mathrm{H}(13 \mathrm{~A})$ & 9122 & 11492 & -4452 & 71 \\
\hline $\mathrm{H}(13 \mathrm{~B})$ & 8367 & 10651 & -5169 & 71 \\
\hline $\mathrm{H}(13 \mathrm{C})$ & 9227 & 10430 & -3975 & 71 \\
\hline $\mathrm{H}(14)$ & 6939 & 9714 & -1222 & 36 \\
\hline $\mathrm{H}(16 \mathrm{~A})$ & 8728 & 9314 & 2340 & 47 \\
\hline $\mathrm{H}(16 \mathrm{~B})$ & 10053 & 9324 & 1520 & 47 \\
\hline $\mathrm{H}(17 \mathrm{~A})$ & 8289 & 7723 & 1823 & 69 \\
\hline $\mathrm{H}(17 \mathrm{~B})$ & 9839 & 7831 & 2408 & 69 \\
\hline $\mathrm{H}(17 \mathrm{C})$ & 9627 & 7736 & 1028 & 69 \\
\hline $\mathrm{H}(1 \mathrm{O} 2)$ & $5210(20)$ & 13855(15) & $-3080(20)$ & $60(7)^{*}$ \\
\hline
\end{tabular}


Table 6. Torsion angles $\left[^{\circ}\right]$ for Hart 1443.

\begin{tabular}{|c|c|}
\hline $\mathrm{O}(1)-\mathrm{C}(1)-\mathrm{C}(2)-\mathrm{C}(3)$ & 69.91(15) \\
\hline $\mathrm{C}(12)-\mathrm{C}(1)-\mathrm{C}(2)-\mathrm{C}(3)$ & $-173.68(13)$ \\
\hline $\mathrm{C}(6)-\mathrm{C}(1)-\mathrm{C}(2)-\mathrm{C}(3)$ & $-40.90(17)$ \\
\hline$C(1)-C(2)-C(3)-C(4)$ & $3.7(2)$ \\
\hline$C(1)-C(2)-C(3)-C(13)$ & $-175.85(14)$ \\
\hline $\mathrm{C}(13)-\mathrm{C}(3)-\mathrm{C}(4)-\mathrm{C}(5)$ & $177.80(14)$ \\
\hline$C(2)-C(3)-C(4)-C(5)$ & $-1.7(2)$ \\
\hline $\mathrm{C}(3)-\mathrm{C}(4)-\mathrm{C}(5)-\mathrm{C}(11)$ & 159.06(14) \\
\hline $\mathrm{C}(3)-\mathrm{C}(4)-\mathrm{C}(5)-\mathrm{C}(7)$ & $-71.17(18)$ \\
\hline$C(3)-C(4)-C(5)-C(6)$ & $35.10(19)$ \\
\hline $\mathrm{O}(1)-\mathrm{C}(1)-\mathrm{C}(6)-\mathrm{C}(8)$ & $-169.93(13)$ \\
\hline $\mathrm{C}(12)-\mathrm{C}(1)-\mathrm{C}(6)-\mathrm{C}(8)$ & 75.72(19) \\
\hline$C(2)-C(1)-C(6)-C(8)$ & $-54.8(2)$ \\
\hline $\mathrm{O}(1)-\mathrm{C}(1)-\mathrm{C}(6)-\mathrm{C}(5)$ & $-45.35(13)$ \\
\hline $\mathrm{C}(12)-\mathrm{C}(1)-\mathrm{C}(6)-\mathrm{C}(5)$ & $-159.70(13)$ \\
\hline $\mathrm{C}(2)-\mathrm{C}(1)-\mathrm{C}(6)-\mathrm{C}(5)$ & $69.78(14)$ \\
\hline$C(4)-C(5)-C(6)-C(8)$ & $68.64(16)$ \\
\hline $\mathrm{C}(11)-\mathrm{C}(5)-\mathrm{C}(6)-\mathrm{C}(8)$ & $-56.33(16)$ \\
\hline$C(7)-C(5)-C(6)-C(8)$ & $-177.82(12)$ \\
\hline$C(4)-C(5)-C(6)-C(1)$ & $-64.54(14)$ \\
\hline $\mathrm{C}(11)-\mathrm{C}(5)-\mathrm{C}(6)-\mathrm{C}(1)$ & $170.48(12)$ \\
\hline$C(7)-C(5)-C(6)-C(1)$ & 48.99(13) \\
\hline $\mathrm{C}(4)-\mathrm{C}(5)-\mathrm{C}(7)-\mathrm{O}(1)$ & $78.45(15)$ \\
\hline $\mathrm{C}(11)-\mathrm{C}(5)-\mathrm{C}(7)-\mathrm{O}(1)$ & $-153.38(13)$ \\
\hline $\mathrm{C}(6)-\mathrm{C}(5)-\mathrm{C}(7)-\mathrm{O}(1)$ & $-35.35(15)$ \\
\hline $\mathrm{C}(1)-\mathrm{C}(6)-\mathrm{C}(8)-\mathrm{C}(14)$ & $-9.7(2)$ \\
\hline$C(5)-C(6)-C(8)-C(14)$ & $-128.70(16)$ \\
\hline $\mathrm{C}(1)-\mathrm{C}(6)-\mathrm{C}(8)-\mathrm{C}(9)$ & $174.55(14)$ \\
\hline $\mathrm{C}(5)-\mathrm{C}(6)-\mathrm{C}(8)-\mathrm{C}(9)$ & $55.54(17)$ \\
\hline C(14)-C(8)-C(9)-C(10) & $128.72(17)$ \\
\hline $\mathrm{C}(6)-\mathrm{C}(8)-\mathrm{C}(9)-\mathrm{C}(10)$ & $-55.55(17)$ \\
\hline C(8)-C(9)-C(10)-C(11) & $56.07(18)$ \\
\hline $\mathrm{C}(9)-\mathrm{C}(10)-\mathrm{C}(11)-\mathrm{O}(2)$ & $-178.85(13)$ \\
\hline C(9)-C(10)-C(11)-C(5) & $-55.26(17)$ \\
\hline
\end{tabular}




\begin{tabular}{lc}
$\mathrm{C}(4)-\mathrm{C}(5)-\mathrm{C}(11)-\mathrm{O}(2)$ & $52.36(17)$ \\
$\mathrm{C}(7)-\mathrm{C}(5)-\mathrm{C}(11)-\mathrm{O}(2)$ & $-73.96(17)$ \\
$\mathrm{C}(6)-\mathrm{C}(5)-\mathrm{C}(11)-\mathrm{O}(2)$ & $175.41(12)$ \\
$\mathrm{C}(4)-\mathrm{C}(5)-\mathrm{C}(11)-\mathrm{C}(10)$ & $-67.91(16)$ \\
$\mathrm{C}(7)-\mathrm{C}(5)-\mathrm{C}(11)-\mathrm{C}(10)$ & $165.77(13)$ \\
$\mathrm{C}(6)-\mathrm{C}(5)-\mathrm{C}(11)-\mathrm{C}(10)$ & $55.14(16)$ \\
$\mathrm{C}(6)-\mathrm{C}(8)-\mathrm{C}(14)-\mathrm{C}(15)$ & $-178.57(15)$ \\
$\mathrm{C}(9)-\mathrm{C}(8)-\mathrm{C}(14)-\mathrm{C}(15)$ & $-3.4(3)$ \\
$\mathrm{C}(8)-\mathrm{C}(14)-\mathrm{C}(15)-\mathrm{O}(3)$ & $-28.8(3)$ \\
$\mathrm{C}(8)-\mathrm{C}(14)-\mathrm{C}(15)-\mathrm{O}(4)$ & $151.84(16)$ \\
$\mathrm{C}(5)-\mathrm{C}(7)-\mathrm{O}(1)-\mathrm{C}(1)$ & $7.61(17)$ \\
$\mathrm{C}(12)-\mathrm{C}(1)-\mathrm{O}(1)-\mathrm{C}(7)$ & $145.90(14)$ \\
$\mathrm{C}(2)-\mathrm{C}(1)-\mathrm{O}(1)-\mathrm{C}(7)$ & $-94.11(14)$ \\
$\mathrm{C}(6)-\mathrm{C}(1)-\mathrm{O}(1)-\mathrm{C}(7)$ & $24.16(15)$ \\
$\mathrm{O}(3)-\mathrm{C}(15)-\mathrm{O}(4)-\mathrm{C}(16)$ & $2.1(2)$ \\
$\mathrm{C}(14)-\mathrm{C}(15)-\mathrm{O}(4)-\mathrm{C}(16)$ & $-178.53(13)$ \\
$\mathrm{C}(17)-\mathrm{C}(16)-\mathrm{O}(4)-\mathrm{C}(15)$ & $-171.29(15)$ \\
& \\
\hline
\end{tabular}


Table 7. Hydrogen bonds for Hart 1443 [ $\AA$ and $\left.{ }^{\circ}\right]$.

\begin{tabular}{lllll}
\hline D-H...A & d(D-H) & d(H...A & $d(D . . A)$ & $<($ DHA $)$ \\
\hline O(2)-H(1O2)...(3)\#1 & $0.85(2)$ & $1.96(2)$ & $2.8150(18)$ & $175(2)$ \\
\hline
\end{tabular}

Symmetry transformations used to generate equivalent atoms:

$\# 1 \mathrm{x}-1 / 2,-\mathrm{y}+5 / 2, \mathrm{z}-1 / 2$ 